\title{
Environmental Management Performance Report April 2000
}

Prepared for the U.S. Department of Energy

Assistant Secretary for Environmental Management

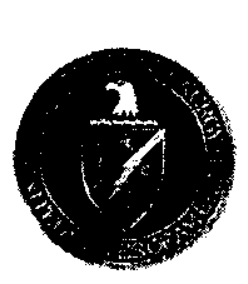

\section{United States}

Department of Energy

Richland Operations Office

P.O. Box 550

Richland, Washington 99352

Approved for Public Release; Further Dissemination Unlimited

RECORD COPY 
DOE/RL-99-83

Revision 3

\section{Environmental Management Performance Report April 2000}

www.hanford.gov/empr/toc.htm

Prepared for the U.S. Department of Energy

Assistant Secretary for Environmental Management

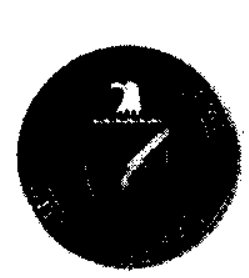

\section{United States}

Department of Energy

Richland Operations Office

P.O. Box 550

Richland, Washington 99352

Approved for Public Release; Further Dissemination Unlimited 
TRADEMARK DISCLAMMER

Reference herein to any specific commercial product, process,

or service by trade name, trademark, manufacturer, or

otherwise, does not necessarily constitute or imply its

endorsement, recommendation, or favoring by the United

States Government or any agency thereof or its contractors or

subcontractors.

This report has been reproduced from the beet available copy. 


\section{RELEASE AUTHORIZATION}

Document DOERL-99-83, Rev. 3

Number:

Document Titte: Environmental Management Performance Report April 2000

This document, reviewed in accordance with DOE Order 241.1, "Scientific and Technical Information Management," and DOE G 241.1-1, "Guide to the Management of Scientific and Technical Information," does not contain classified or sensitive unclassified information and is:

PROVED FOR PUBLIC RELEASE

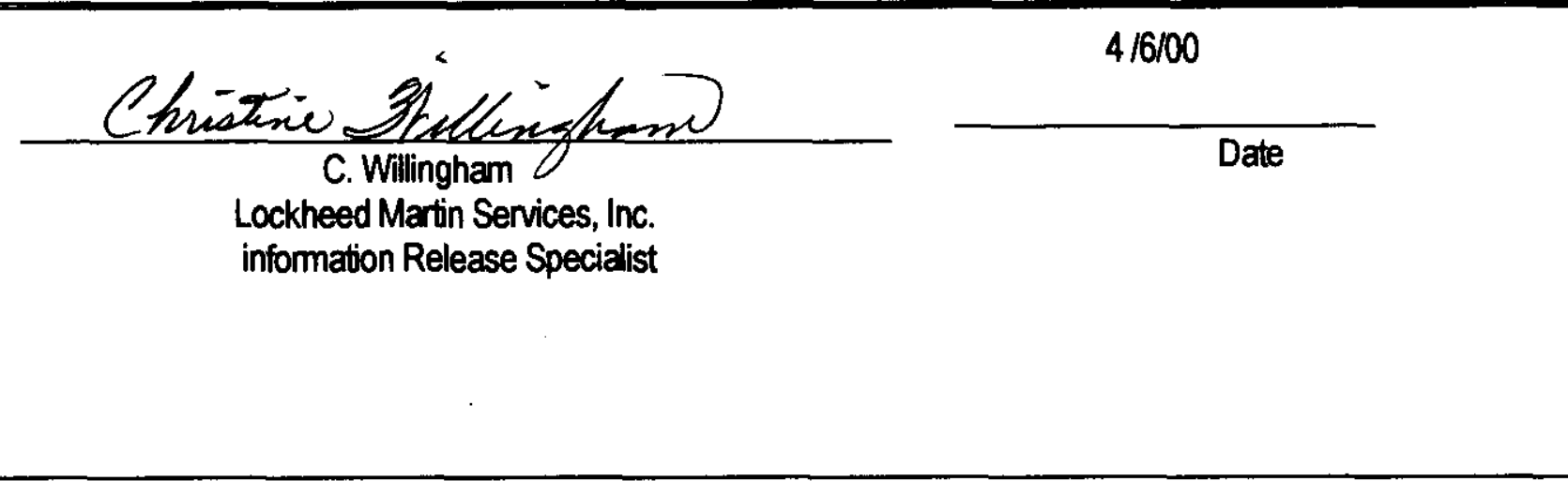

Reviewed for Appiod Tectnobgy, Business Sensitive, Chesified, Copprighted, Export Contoled, Potent, Personeiprivate, Proprietery, Protected CRADA, Trademerk,

Unclessified Controbd Nucber informetion.

Trademerk Disclainer. Reference herein to eny epecific commenciel product, process, or eorvice by trede name, trademerk, menufacturer, $\alpha$ otherwise, does not necesserily constitute or imply its endorsement, recommendetion, or fevoring by the United Statos Govemment or any eqency thereof or its contrectors or aubcontractors. The views end opinions of euthors expreseed herein do not necesserily stcte or reflect those of the United Steles Govemment or any epency thereof. This report has been reproduced from the best aveileble copy

Printed in the United States of Americe. 


\section{INTRODUCTION} Environmental Management (EM) performance by:

- Project Hanford Management Contract (PHMC) through Fluor Hanford, Inc. (FHI) and its subcontractors,

- Environmental Restoration Contract through Bechtel Hanford, Inc. (BHI), and its subcontractors,

- Pacific Northwest National Laboratories (PNNL) for EM and EM Science and Technology (S\&T) Mission, and

- Office of Safety Regulation of the TWRS Privatization Contractor.

This report is a monthly publication that summarizes EM Site performance under RL Operations Office. It is organized by the four sections listed above, with each section containing an Executive Summary and Area Performance Summaries.

The report date on the cover has been changed to reflect the month in which the report is released. 


\section{Project Hanford Management Contractor}

Environmental Management Performance Report to DOE Richland Operations Office April 2000

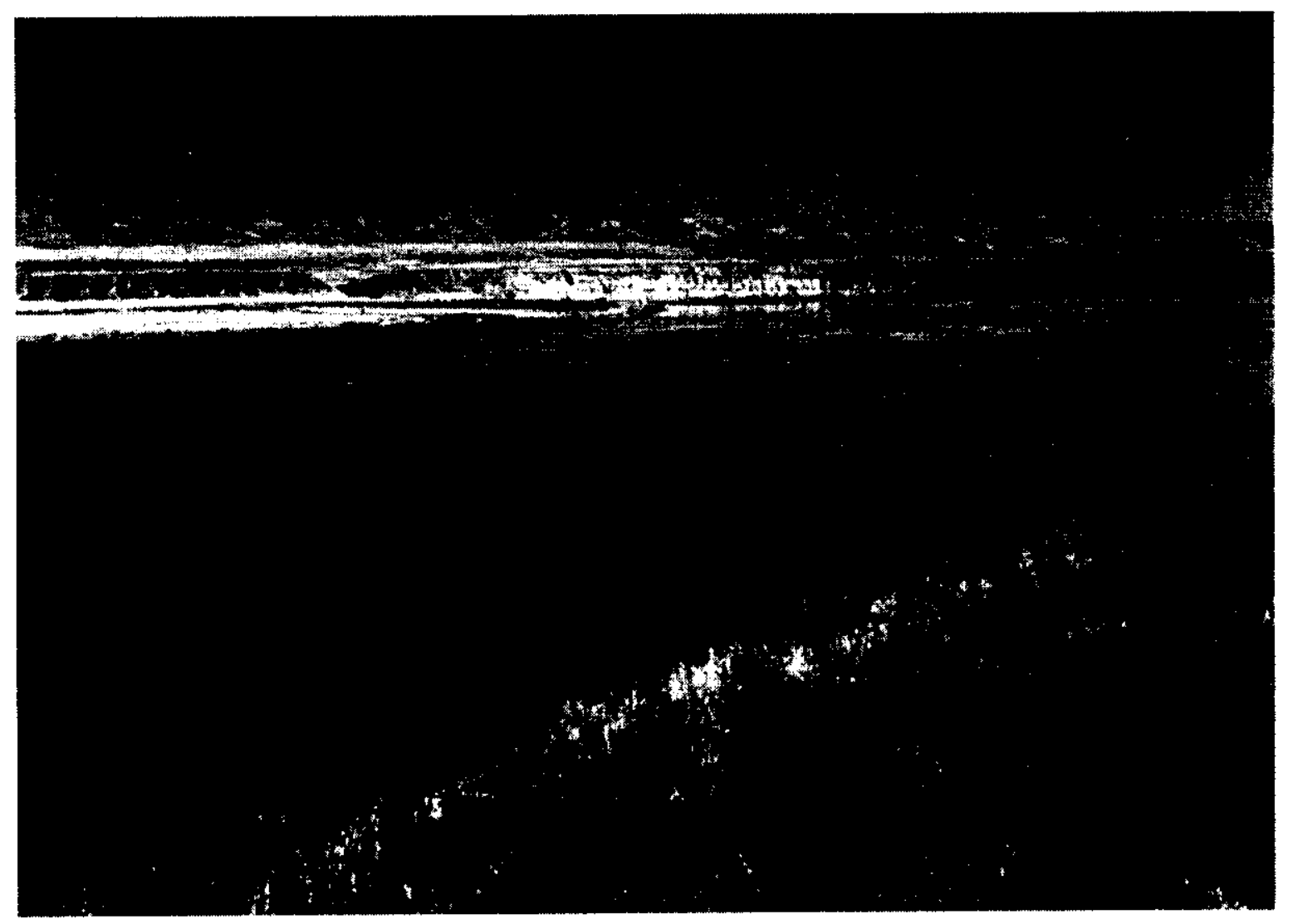

\section{Fluor Hanford}

A Fluor Global Services Company 


\section{Table of Contents}

Section

A. Executive Summary

B: 1. Waste Management

B: 2. Analytical Services (222-S, HASP, WSCF)

C. Spent Nuclear Fuel

D: 1. Nuclear Material Stabilization

D: 2. River Corridor

E. Landlord

F. Support

G. HAMMER

H. Advanced Reactors Transition

I. EM - 50 Science \& Technology Activities

J. National Programs 


\section{INTRODUCTION}

7 he purpose of this report is to provide the Department of Energy Richland Operations Office 1 (DOE-RL) a report of the Project Hanford Management Contractors' (PHMC)

Environmental Management (EM) performance by Fluor Hanford (FH) and its subcontractors. This report is a monthly publication that summarizes the PHMC EM performance. In addition, it includes some PHMC-level data not detailed elsewhere in the report.

Section A, Executive Summary, provides an executive level summary of the cost, schedule, and technical performance described in this report. It summarizes performance for the period covered, highlights areas worthy of management attention, and provides a forward look to some of the upcoming key performance activities as extracted from the PHMC baseline.

The remaining sections provide detailed performance data relative to each individual Project (e.g., Waste Management, Spent Nuclear Fuels, etc.), in support of Section A of the report. A glossary of terms is provided at the end of this report for reference purposes. Unless otherwise noted, the Safety, Conduct of Operations, and Cost/Schedule data contained herein is as of February 29, 2000. All other information is as of March 21, 2000. 


\section{INTRODUCTION}

This section provides an executive level summary of the performance information covered in this report and is intended to bring to Management's attention that information considered to be most noteworthy. All cost, schedule, milestone commitments, and safety data is current as of February 29. Accomplishments, Issues and Integration items are current as of March 21 unless otherwise noted.

The section begins with a description of notable accomplishments that have occurred since the last report and are considered to have made the greatest contribution toward safe, timely, and costeffective clean up. Following the accomplishment section is an overall fiscal year-to-date summary analysis addressing cost, schedule, and milestone performance. Overviews of safety ensue. The next segment of the Executive Summary, entitled Critical Issues, is designed to identify the high-level challenges to achieving cleanup progress.

The Key Integration Activities section follows next, highlighting PHMC activities that cross contractor boundaries and demonstrate the shared value of partnering with other Site entities to accomplish the work. Concluding the Executive Summary, a forward-looking synopsis of Upcoming Planned Key Events is provided.

\section{NOTABLE ACCOMPLISHMENTS}

- As of March 17, 2000 a total of 201 cans of Plutonium oxides and sludges have been stabilized through thermal stabilization (28 items since last report).

- Progress is nearly complete on the installation of three additional muffle furnaces for thermal stabilization of oxides and on installation of the $\mathrm{Mg}(\mathrm{OH})_{2}$ process system glove boxes for $\mathrm{Pu}$ Solution Stabilization.

- Welding of all 220 Canister Storage Building (CSB) standard storage tubes necessary for fuel removal from $\mathrm{K}$ Basins was completed.

- The Facility Evaluation Board completed the 222-S and WSCF laboratories' audit and issued the final FEB report in February 2000, with improvements in 9 of 10 areas and an overall rating of " 3 ".

- A total of 154 boxes (645 cubic meters) of mixed low-level waste have been shipped to ATG. This waste volume represents an effective Central Waste Complex storage volume reduction of 1,325 cubic meters due to waste over-packing. ATG has completed treating, and Hanford has accepted back for disposal, twenty-five (25) macro-encapsulated waste containers totaling 66 cubic meters of waste as planned (data as of March 30, 2000).

- Progress continues toward Accelerated Deactivation of the 327 Facility. The removal of $\sim 116$ of $\sim 300$ sample cans from Dry Storage was completed.

- The 324 Building team completed its first shipment since the fall of 1998 when a grout container was shipped to the 200 Area Low Level Burial Ground (LLBG). This shipment closes out all waste characterization and packaging, and shipping issues that have confronted the 324 team for the past $1 \frac{1}{2}$ years. 
- The Project Management Institute's Regional Project of the Year Award was presented to the 300 Area Fuel Supply Shutdown Waste Acid Treatment System (WATS) Resource

Conservation and Recovery Act of 1976 (RCRA) Closure Project.

\section{Performance Data and analysis}

The following provides a brief synopsis of overall PHMC Environmental Management (EM) 1 cost, schedule, and milestone performance.

\section{FY 2000 Cost and Schedule Performance}

Cost Performance - Fiscal-year-to-date (FYTD) cost performance reflects a two percent ( $\$ 5.4$ million) unfavorable cost variance that is within the established $+10 /-5$ percent threshold.

Schedule Performance - There is a FYTD eight percent (\$18.2 million) unfavorable schedule variance.

Data Through February 2000

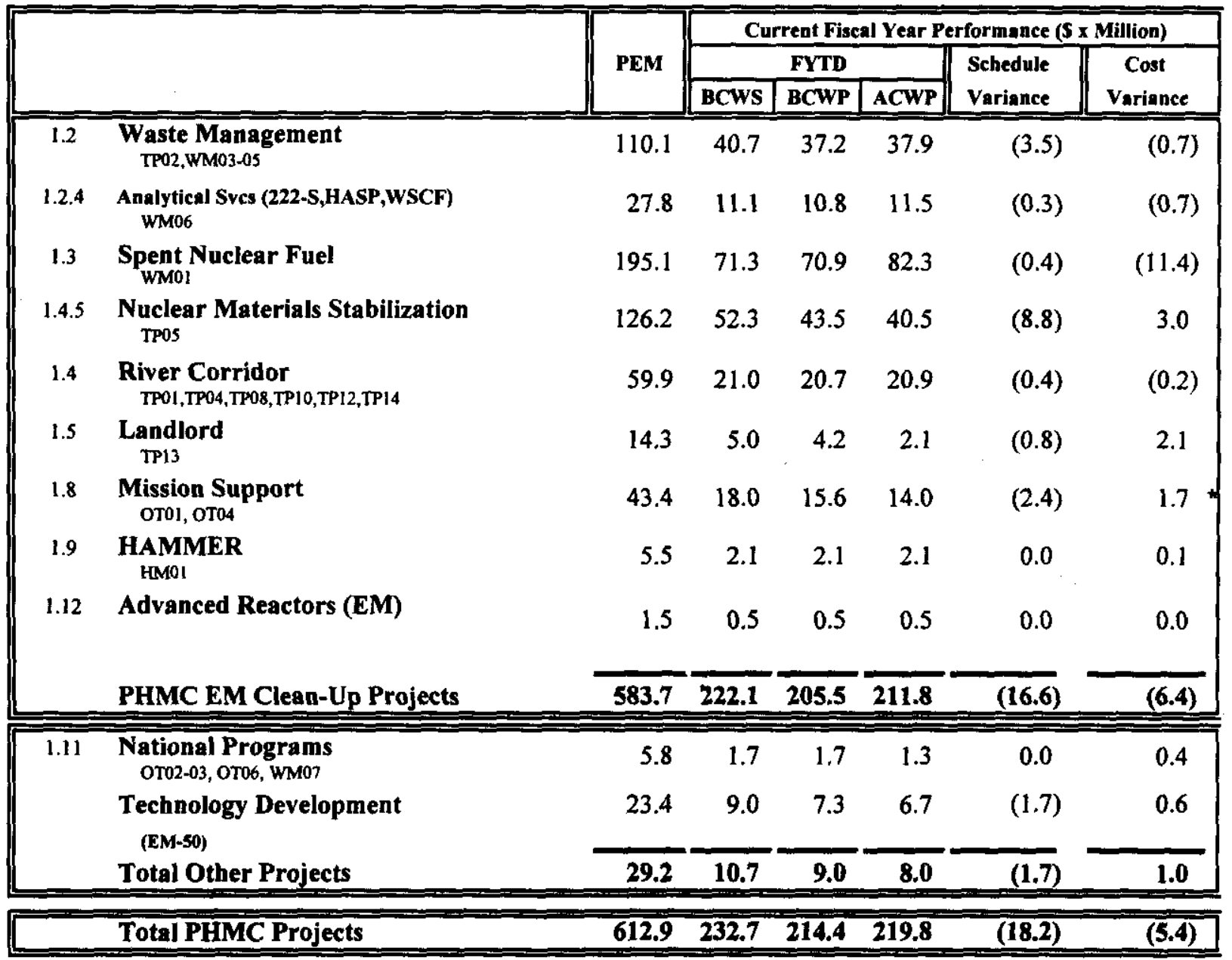

Notes: Column headings (BCWS, BCWP, etc.) are defined in the glossary at the end of the report. Calculations are based on Project Baseline Summary detail. Waste Management and Nuclear Materials Stabilization have included RL-Directed costs (e.g. steam and laundry) in the PEM BCWS. Advanced Reactors (EM) have included steam. 
The following Cost/Schedule and Variance to Plan chart provides an overall graphical view of fiscal year to date performance and cost and schedule performance indicators.

\section{FY 2000 Cost / Schedule Performance Cumulative to Date Status}

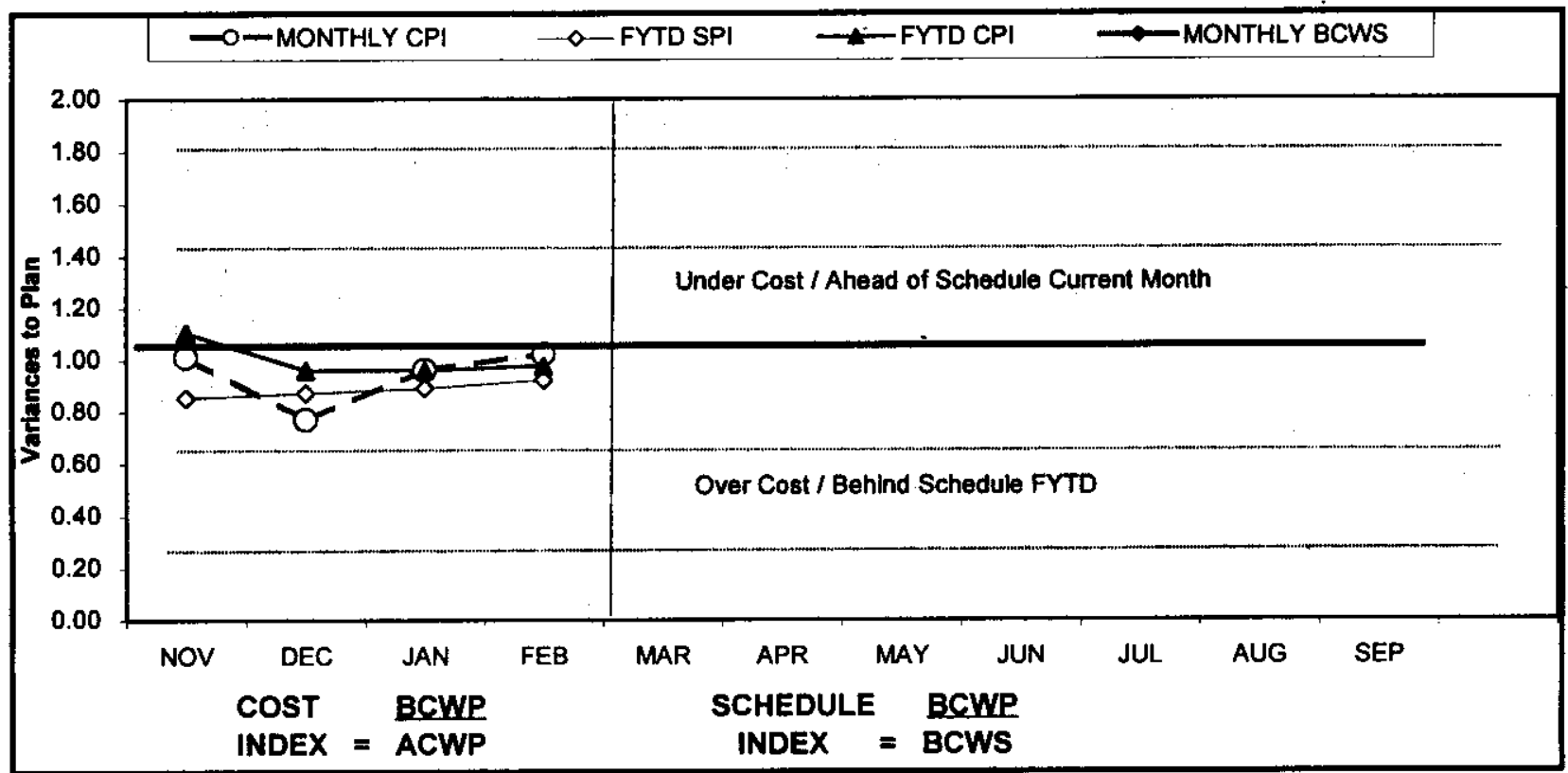

\begin{tabular}{|c|c|c|c|c|c|c|c|c|c|c|c|c|}
\hline FY 2000 & OCT & NOV & DEC & JAN & FEB & MAR & APR & MAY & JUN & JUL & AUG & SEP \\
\hline MONTHLY SPI & 0.91 & 0.80 & 0.91 & 0.94 & 1.02 & & & & & & & \\
\hline MONTHLY CPI & 1.60 & 1.01 & 0.77 & 0.96 & 1,02 & & & & & & & \\
\hline FYTD SPI & 0.94 & 0.85 & 0.87 & 0.89 & 0.92 & & & & & & & \\
\hline FYTD CPI & 1.29 & 1.11 & 0.96 & 0.96 & 0.98 & & & & & & & \\
\hline MONTHLY BCWS & S 32,596 & \begin{tabular}{|l}
55,173 \\
\end{tabular} & 43,048 & 45,561 & $\begin{array}{|ll|}5 & 57,746 \\
\end{array}$ & & & & & & & \\
\hline MONTHLY BCWP & S 29,526 & $\$ 44,175$ & 39,136 & 43,015 & 58,630 & & & & & & & \\
\hline MONTHLY ACWP & \$ 18,464 & $\$ \quad 43,727$ & $\begin{array}{ll}5 & 50,940 \\
\end{array}$ & S 44,783 & \begin{tabular}{|l|}
57,414 \\
\end{tabular} & & & & & & & \\
\hline FYTD BCWS & \$ 31,193 & \$ 86,366 & $\begin{array}{|ll|}S & 129,414 \\
\end{array}$ & \begin{tabular}{|ll} 
& 174,975 \\
\end{tabular} & \begin{tabular}{|l|l|}
$S \quad 232,721$ \\
\end{tabular} & & & & & & & \\
\hline FYTD BCWP & S 29,464 & \$ 73,639 & \begin{tabular}{|l|l|}
5 & 112,775 \\
\end{tabular} & $\begin{array}{ll} & 155,790 \\
\end{array}$ & 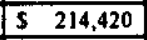 & & & & & & & \\
\hline FYTD ACWP & S 22,892 & $\$ 66,619$ & $\begin{array}{|ll|}5 & 117,559 \\
\end{array}$ & \begin{tabular}{|ll}
5 & 162,342 \\
\end{tabular} & \begin{tabular}{|ll}
5 & 219,756 \\
\end{tabular} & & & & & & & \\
\hline
\end{tabular}

\section{Milestone Performance}

Milestones represent significant events in project execution. They are established to provide a higher level of visibility to critical deliverables and to provide specific status about the accomplishment of these key events. Because of the relative importance of milestones, the ability to track and assess milestone performance provides an effective tool for managing the PHMC EM cleanup mission.

FYTD milestone performance (Enforceable Agreement [EA], U.S. Department of Energy-Headquarters [DOE-HQ], and RL) shows that 22 of 29 approved baseline milestones (76 percent) were completed on or ahead of schedule, 2 milestones ( 7 percent) were completed late, and 5 milestones (17 percent) are overdue. The five overdue milestones are associated with three projects: Nuclear Material Stabilization-two, Environmental Management (EM)-50-two, and Mission Support-one. These overdue milestones do not share a common cause. 
In addition to the FY2000 milestones described above, there are three overdue milestones from the prior fiscal year (FY1999). Further details regarding these milestones may be found in the Project Sections.

FY 2000 information is depicted graphically below and on the following page. For additional details related to the data in the graphs and prior year milestones, refer to the relevant project section titled "Milestone Exception Report."

FY 2000 information reflects the current approved baseline. Changes in both the number and type of milestones from month to month are the result of Baseline Change Requests (BCRs) approved during the year.

\begin{tabular}{|c|c|c|c|c|c|c|c|c|}
\hline \multirow[b]{2}{*}{ MILESTONE TYPE } & \multicolumn{4}{|c|}{ FISCAL YEAR-TO-DATE } & \multicolumn{3}{|c|}{ REMAINING SCHEDULED } & \multirow[b]{2}{*}{$\begin{array}{c}\text { TOTAL } \\
\text { FY } \\
2000\end{array}$} \\
\hline & $\begin{array}{c}\text { Completed } \\
\text { Early }\end{array}$ & $\begin{array}{c}\text { Completed } \\
\text { On } \\
\text { Schedule }\end{array}$ & $\begin{array}{c}\text { Completed } \\
\text { Late }\end{array}$ & Overdue & $\begin{array}{c}\text { Forecast } \\
\text { Early }\end{array}$ & $\begin{array}{c}\text { Forecast On } \\
\text { Schedule }\end{array}$ & $\begin{array}{c}\text { Forecast } \\
\text { Late }\end{array}$ & \\
\hline Enforceable Agreement & 13 & 2 & 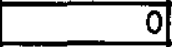 & 1 & 0 & 17 & $\overline{0}$ & 33 \\
\hline DOE-HQ & 0 & 0 & 요 & 1 & 0 & 3 & 0 & 4 \\
\hline $\mathrm{RL}$ & 4 & 3 & 2 & 3 & 인 & 49 & 1 & 62 \\
\hline Total Project & $\overline{17}$ & 5 & 2 & 5 & 0 & 69 & 1 & 99 \\
\hline & $\begin{array}{l}\text { mpleted On Sc } \\
\qquad 17 \%\end{array}$ & $\begin{array}{r}\text { Completed } \\
58 \% \%\end{array}$ & Early & Cor & $\begin{array}{l}\text { ted Late } \\
\% \\
\text { Overdu } \\
17 \%\end{array}$ & & & \\
\hline
\end{tabular}
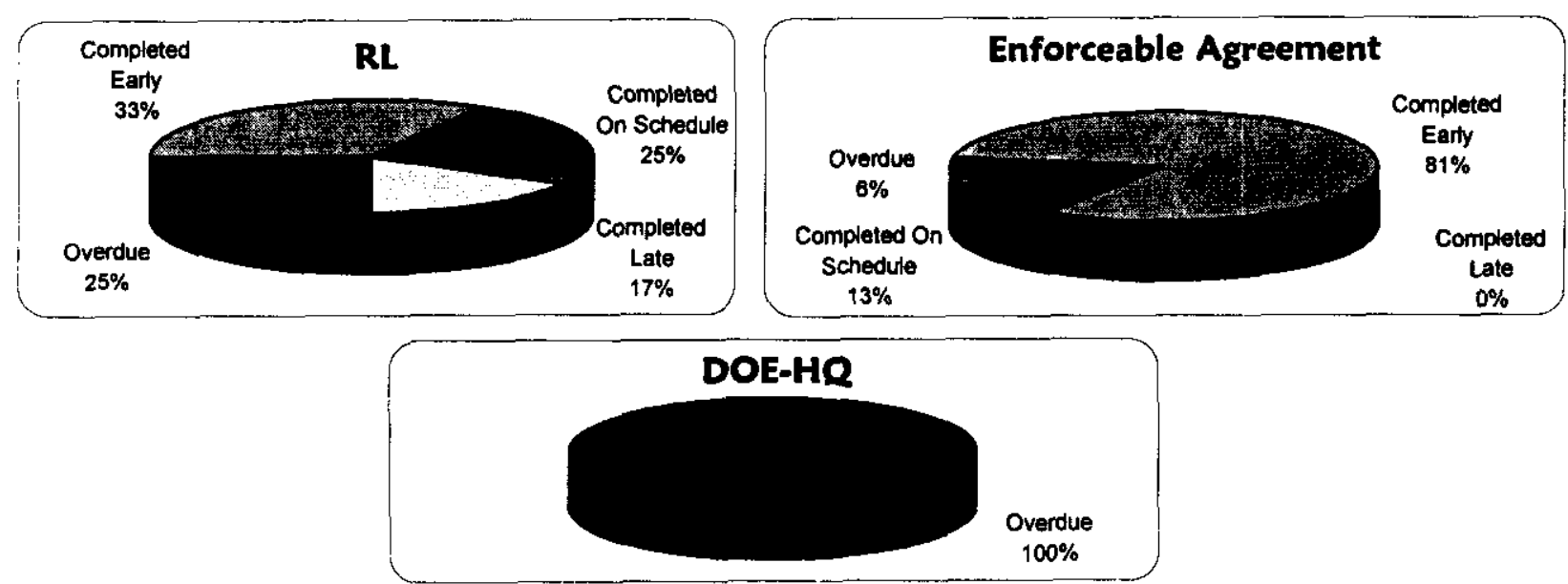
MILESTONE EXCEPTIONS
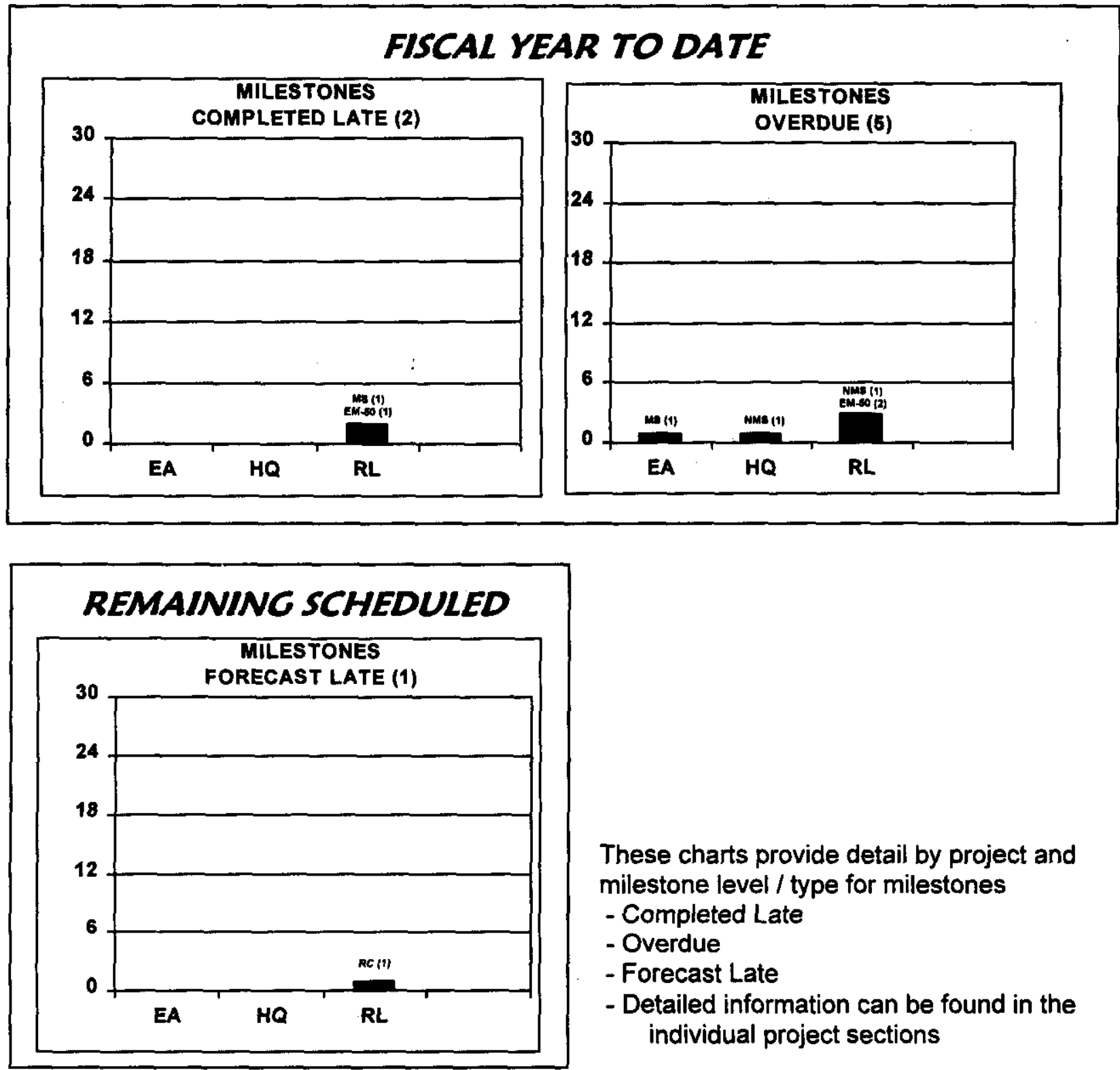

These charts provide detail by project and milestone level / type for milestones

- Completed Late

- Overdue

- Forecast Late

- Detailed information can be found in the individual project sections 


\section{SAFETY OVERVIEW}

7 he focus of this section is to document trends in occurrences. Improvements in these rates are due to the efforts of the PHMC workforce as they implement the Integrated ES\&H

Management System (ISMS), work towards achieving Voluntary Protection Program (VPP) "star" status, and accomplish work through Enhanced Work Planning (EWP). Safety and health statistical data is presented in this section.

\section{Significant SAFETY aNd Health EVENTS}

Rates have been stable for nearly two years. This safety performance plateau has been recognized by the safety organizations, and Fluor Hanford kicked off its Integrated Safety Approach initiative on December 6, 1999 in order to take safety performance to a new level. This initiative focuses on the "people side" of accident prevention.

\section{Total OSHA Recordable Case Rate}

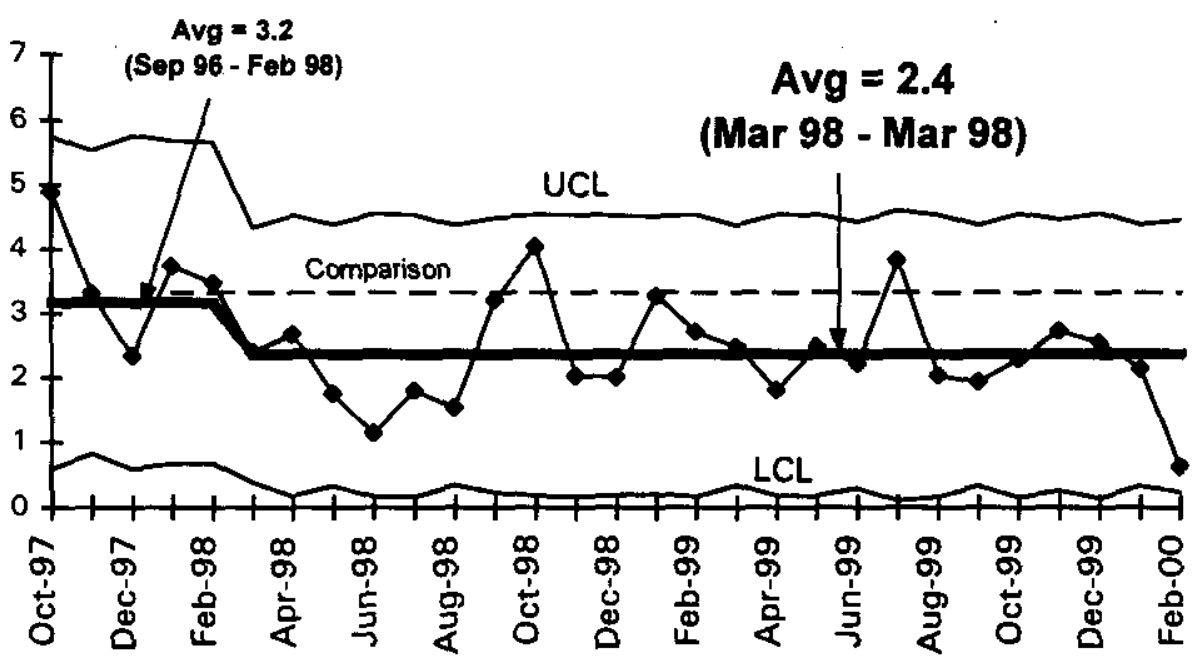

PHMC

FY $1999=2.5$

FY $2000=2.0$

Contractor Comparison

Average $=3.3$

This indicator had a

nearly significant decrease in February.

There were only 3 recordable cases, a new low record for the PHMC. Consolidation of the projects under Fluor Hanford, and actions taken at the end of FY 1999 to look at injury sources appears to be having an effect. 


\section{OSHA LOST/RESTRICTED WORKDAY CASE RATE}

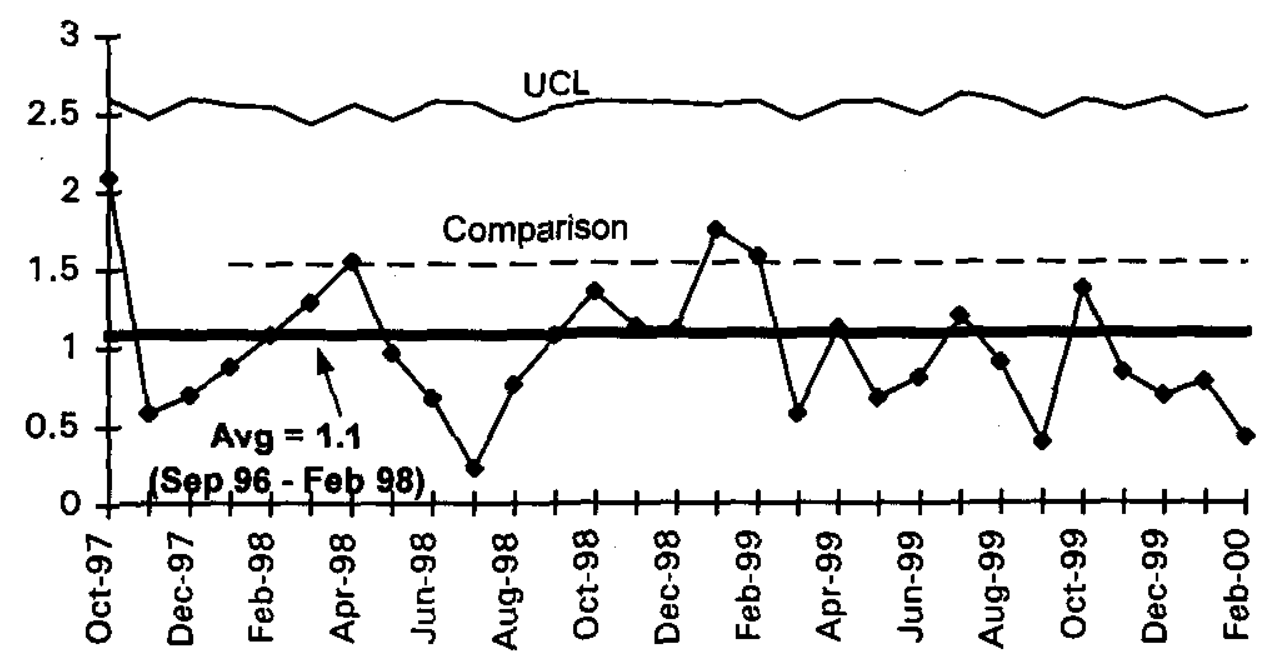

PHMC

FY $1999=1.0$

FY 2000 to date $=0.8$

Contractor Comparison

Average $=1.5$

The data have been stable for the past two years. Most of the recent months (over the past year) have been well below average, a hopeful sign of potential improvement.

\section{First Aid Case Rate}

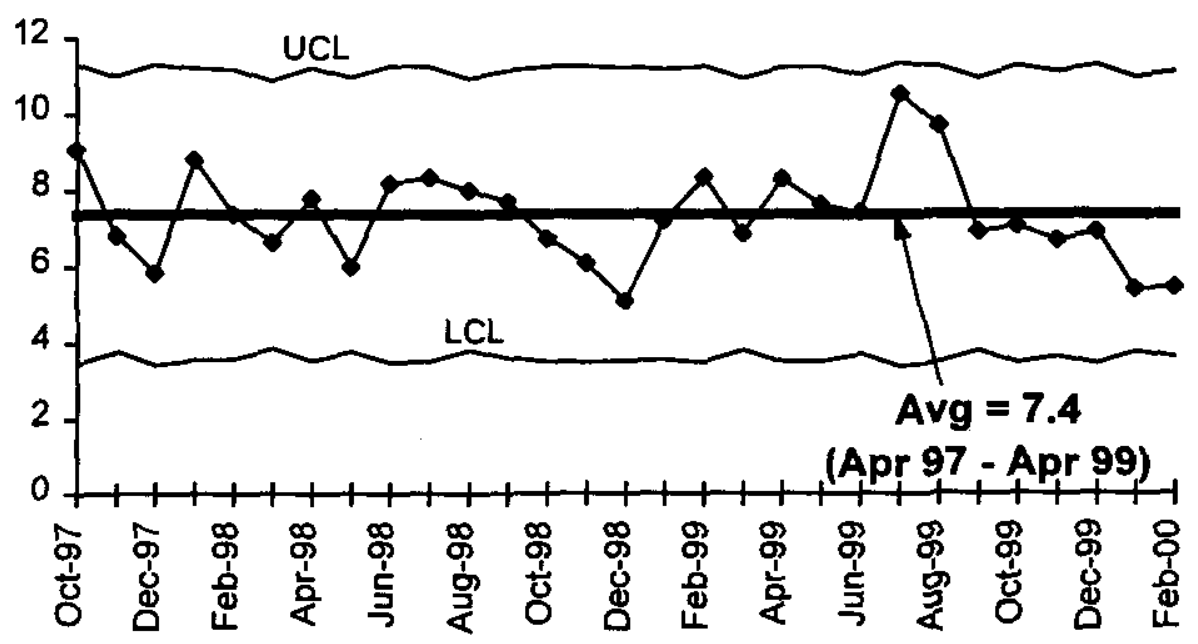

\section{PHMC}

First Aid Rate undergoes seasonal cycles. Increases occur in warmer weather due to insect and animal encounters, and due to wind related minor injuries. The First Aid Rate has remained relatively stable; a good indicator that injuries are not being under-reported. 


\section{DOE Safety Cost Index}

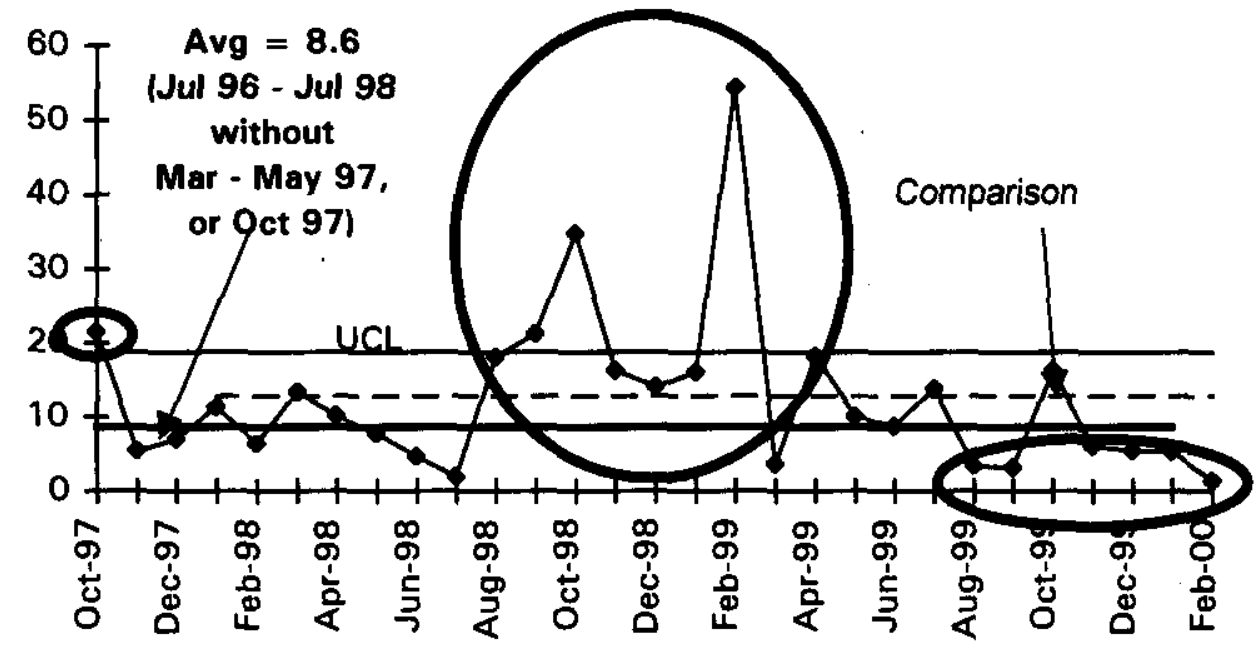

PHMC

FY $1999=16$

FY 2000 to date $=6.7$

Contractor Comparison

Average $=12.8$

There has been a long term cycle over the past three years of decreases for 7 to 9 months, followed by increases. Past 6 of 7 months have been one standard deviation below average, a significant decrease. New average and control limits will be calculated when the data stabilize.

\section{CRITICAL TECHNICAL ISSUES}

\section{- 324 FACILITY BEHIND SCHEDULE}

The 324 Building Fire Hazards Analysis (FHA) revision supporting the 324 Building Safety Analysis Report (SAR) update resulted in revised combustible load limits. An implementation plan has been developed that allows either 1) work to continue while maintaining revised combustible load limits or 2) implements compensatory measures, such as establishing a fire watch, eliminating ignition sources, and shutting off lights when not needed. This change will not cause a schedule impact, but it may create a cost impact to work in progress. Evaluation of alternative fire suppression capabilities to allow an increase in combustible load limits continues.

- CERTIFICATION OF HANFORD'S TRU PROJECT NECESSARY TO INITIATE WASTE SHIPMENT TO WIPP

Delays in performing the closeout audit impact the ability to ship waste to WIPP. The contractor continues working with the Carlsbad Area Office, the Environmental Protection Agency and the New Mexico Environment Department to achieve WIPP certification of Hanford's TRU Project. Plans are to achieve WIPP Certification and initiate TRU shipments in May 2000.

- CRACK DISCOVERED ON B PLANT W-059 DUCT REPLACEMENT

Due to the crack discovered in the duct replacement, the completion of B Plant turnover Memorandum Of Agreement (MOA) may be delayed. All prerequisite actions for the cracked exhaust duct testing are complete, and negotiations are ongoing with $\mathrm{FH}, \mathrm{RL}$, and $\mathrm{BHI}$ on corrective actions. 


\section{KEY INTEGRATION ACTIVITIES}

The following are the key technical integration activities that are currently underway and cross

project/contractor lines. These activities are being addressed by inter-discipline and interproject groups and demonstrate that Hanford Site contractors are working together to accomplish the EM Clean up mission.

- Spent nuclear fuel (SNF) final disposition interface activities, including OCRWM QA Program implementation, ongoing with National SNF Program.

- SNF Project fuel removal acceptance criteria and conceptual design reviews for 324 Building (B Cell) ongoing with River Corridor Project.

- K Basins sludge removal and Shippingport (PA) Pressurized Water Reactor Core 2 SNF removal implementation activities ongoing with Waste Management.

- Nuclear Material Stabilization Project continues working with PNNL on activities associated with the $\mathrm{Mg}(\mathrm{OH})_{2}$ process in order to accelerate the solution stabilization process, and polycube stabilization issues (gathering data for the SAR).

- Analytical Services continues to support BNFL efforts to establish required analytical support for glassification operations.

- In the longer term, BNFL could utilize unused space at WSCF for cold run test support and process laboratory analytical equipment testing.

- The 222-S laboratory, with some refurbishment might become a low cost option to a new large-scale laboratory associated with the glassification facility.

\section{Upcoming Planned Key Events}

$T$ he following Key events are extracted from the authorized baseline and are currently expected to be accomplished during the next eight months. Most are EA, HQ or DNFSB Milestones.

\section{Waste Management:}

- 242A Evaporator Operations -- Conduct 242-A Evaporator Campaign beginning in April 2000, including the additional volume to support the River Protection Project.

- MLLW Treatment -- Treat 1,160 cubic meters (includes 100 cubic meters stretch) of MLLW at ATG by August 2000; return Land Disposal Restriction compliant waste for disposal.

- Suspect TRU Waste Retrieval -- Retrieve 400 drums of suspect TRU waste from the LowLevel Burial Grounds by September 2000 (Stretch).

- Accelerate Readiness to Receive Spent Nuclear Fuel K Basin Sludge -- Clear three sections of the T Plant Canyon deck in FY 2000 and complete entire deck clearing by FY 2001. Develop design requirements by September 2000 for acceptance of $\mathrm{K}$ Basin sludge at T Plant. 


\section{Spent Nuclear Fuels:}

- Complete integrated subsystem testing of the CVD facility by the end of May 2000.

- Deliver first shipment of Multi-Canister Overpacks (MCOs) and baskets by June 1, 2000.

- Complete Cask Loadout System (CLS) startup testing by mid-June 2000.

- Begin DOE Operational Readiness Review for fuel removal by mid September 2000. Begin K West Basin fuel removal, drying \& storage operations by November 30, 2000.

\section{River Corridor Project:}

- Complete all B Plant closeout activities by March 2000.

- Complete ISMS verification of Phase I \& II readiness activities by May 15, 2000.

- Issue the final report for the 300 Area Waste Acid Treatment System (WATS) Resource Conservation and Recovery Act (RCRA) Closure Activities by September 2000.

- Complete Removal of 324 Building Radiochemical Engineering Cell (REC) B Cell Mixed Waste (MW) and Equipment by November 2000.

\section{Nuclear Materials Stabilization:}

- Begin Pu solution stabilization via $\mathrm{Mg}(\mathrm{OH})_{2}$ in $\mathrm{FY} 2000$.

- Deliver glove boxes and equipment for installation by April 11, 2000.

- Complete ORR and training activities.

- Startup Cementation operations in the 4th quarter of FY 2000.

- Complete W-460 Facility Design by April 2000.

- Begin metal stabilization processing in November 2000. 


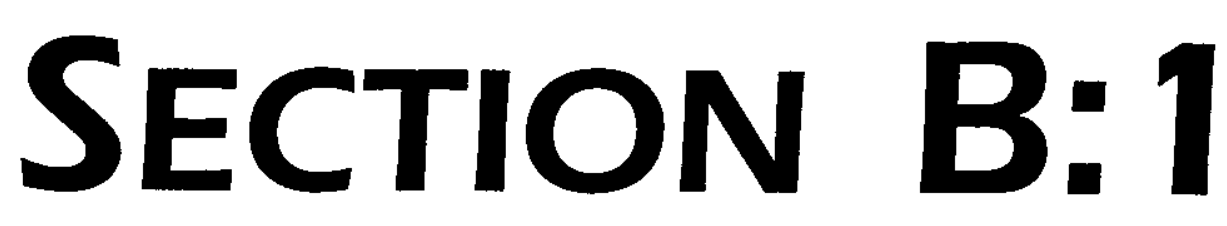

\title{
WASTE
}

\section{MANAGEMENT}

PROJECT MANAGERS

\author{
H. E. Bilson, RL \\ Phone: (509) 376-6628
}

E. S. Aromi Jr., WMH Phone: (509) 372-1033 


\section{SUMMARY}

Waste Management consists of the Solid Waste Storage and Disposal, Project Baseline Summary (PBS) WM03, Work Breakdown Structure (WBS) 1.2.1; Solid Waste Treatment, PBS WM04, WBS 1.2.2; Liquid Effluents - 200 Area, PBS WM05, WBS 1.2.3.1; and the Waste Encapsulation and Storage Facility, PBS TP02, WBS 1.4.2.

NOTE: Unless otherwise noted, the Safety, Conduct of Operations, and Cost/Schedule Date contained herein is as of February 29, 2000. Other information is updated as noted.

Discussions are underway to obtain Carlsbad Area Office (CAO) support for the closure audit of . Hanford's TRU Project on April 17, 2000. All five Corrective Action Reports (CARs) have been completed and are being routed through DOE-RL for transmittal to CAO. Plans are to achieve WIPP Certification and initiate TRU shipments in May of 2000.

Fiscal-year-to-date milestone performance (EA, DOE-HQ and RL) shows that one of one milestones (100 percent) were completed on or ahead of schedule this reporting period.

\section{ACCOMPLISHMENTS}

- Disposed of 74,800 $\mathrm{ft}^{3}$ (FYTD) of Low Level Waste (LLW) in the burial grounds, as planned.

- $\quad$ Processed 3.9 million gallons (February FYTD) of wastewater through the 200 Effluent Treatment Facility supporting River Protection Project (RPP), ERC 200-UP-1 Groundwater, N-Basin Water, and ERDF Leachate, as planned. FYTD through March 27, 2000, 6.6 million gallons of wastewater have been processed. Evaluated support to additional feed volume in the upcoming 242A Evaporator campaign in support of RPP.

- Completed nondestructive examination (NDE) on 339 drums, radiography on 25 boxes, non-destructive assays of 273 drums, processing of 29 drums through the low-level waste repackaging/compaction glovebox, and visual examinations of 25 transuranic drums at the Waste Receiving and Processing (WRAP) facility, as planned through March 30, 2000.

- $\quad$ Shipped 154 boxes, totaling 645 cubic meters, of mixed low-level waste to ATG. This waste volume represents an effective CWC storage volume reduction of 1,325 cubic meters due to waste over-packing. ATG has completed treating, and Hanford has accepted back for disposal, twenty-five (25) macro-encapsulated waste containers totaling 66 cubic meters of waste as planned (all data as of March 30,2000).

- The final Liquid Waste Processing Facility (LWPF) acid spill accident investigation report and accompanying failure analysis was issued February 29, 2000 and is available on the Internet (http://www.hanford.gov/safety/accident.html).

\section{SAFETY}

The project's safety rates are stable at relatively high values. The October 1999 Lost Away Case was a severe Acid Burn injury. However, this has been the only lost away workday case in 16 months. The project has exceeded the 500,000 safe hours. 

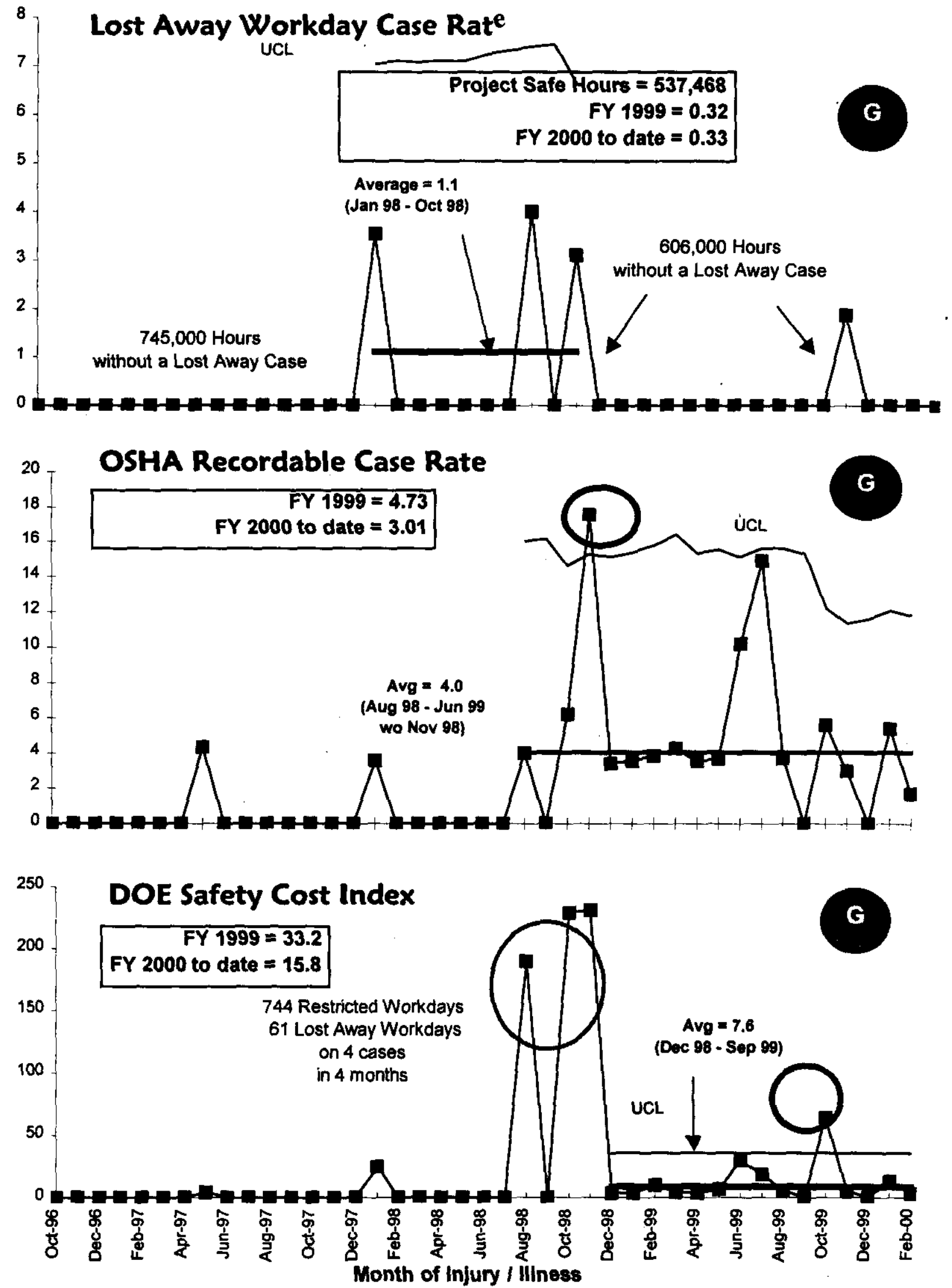


\section{CONDUCT OF OPERATIONS / ISMS STATUS} CONDUCT OF OPERATIONS EVENTS PER 200,000 HOURS

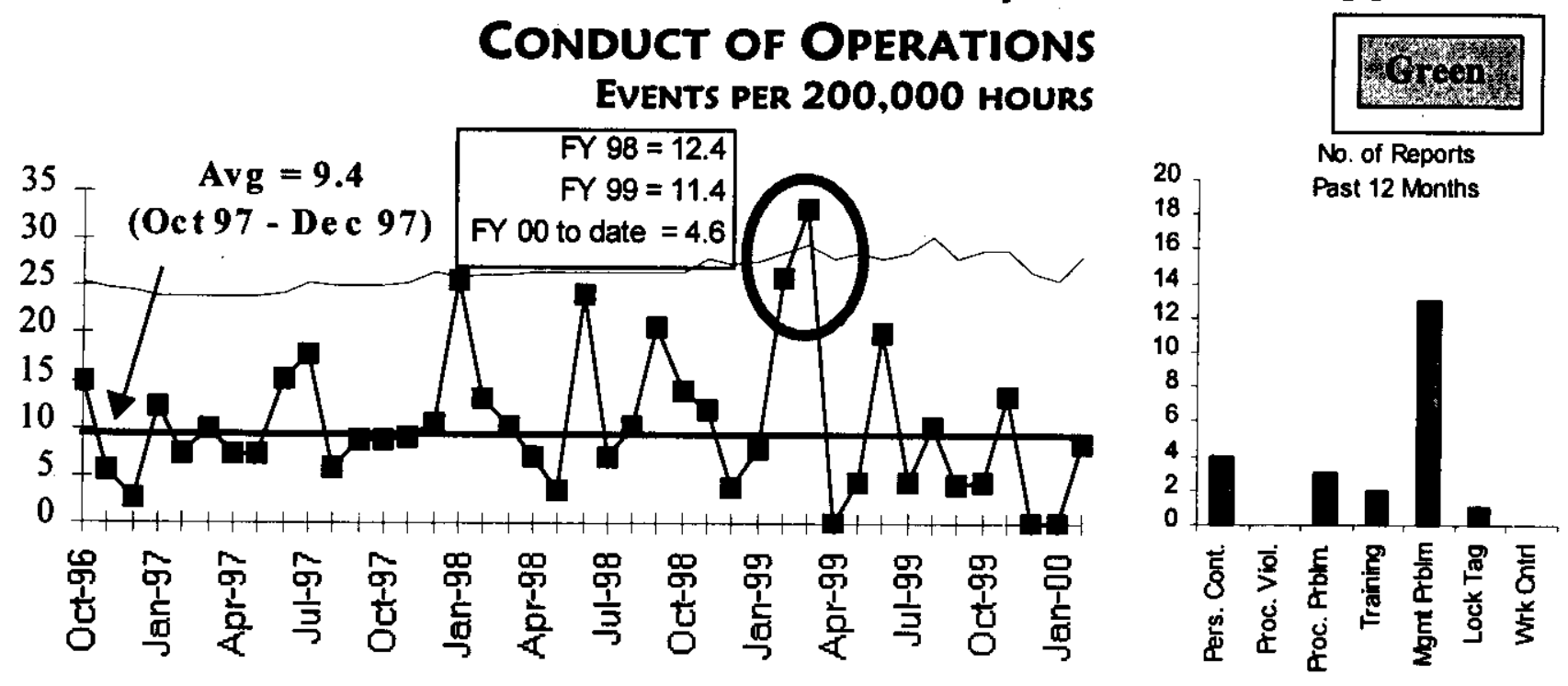

\section{ISMS STATUS}

\section{Completed activities:}

- $\quad$ Complied with MP-003 format changes and guidance. Submitted draft System Descriptions (SDs), for WMP / AS for inclusion into that document.

- ISMS Self Assessment completed with Noteworthy Practices and Opportunities for Improvement identified.

- Training Sessions 1 \& 2 completed, and 12 Communication Bulletins written and distributed.

- Drafts of WMP's Authorization Agreements are written and in the final review process, prior to DOE approval.

- ISMS Workshop III completed.

\section{Planned Actions:}

- $\quad$ Conduct Training Session 3 (DRAFT--ISMS Verification status and Path forward Actions)

- Revise and issue procedures identified for inclusion in SD

- $\quad$ Complete and issue Self Assessment reports for both WMP and AS

- Develop Corrective Action Plans and close remaining issues

- Submit final SD

- $\quad$ Prepare and implement review process for Declaration of Readiness

- Declare Readiness

- Generate \& implement outyear plan to sustain and maintain ISMS effort 


\section{BREAKTHROUGHS / OPPORTUNITIES FOR IMPROVEMENT}

No Breakthroughs or Opportunities for Improvement are identified at this time.

\section{UPCOMING ACTIVITIES}

WIPP Certification and Waste Shipments - Discussions are underway to obtain CAO support for the closure audit on April 17, 2000. Complete WIPP Certification of Hanford's TRU Project and initiate TRU shipments in the spring of 2000.

242A Evaporator Operations - Conduct 242-A Evaporator Campaign beginning in April 2000 , including the additional volume to support RPP.

RH TRU PMP - Issue Project Management Plan for RH TRU in June 2000 to meet M-91 milestone.

MLLW Treatment - Treat 1,160 cubic meters (includes 100 cubic meters stretch) of MLLW at ATG by August 2000; dispose of Land Disposal Restriction compliant waste by September 2000 .

Suspect TRU Waste Retrieval - Retrieve 400 drums of suspect TRU waste from the LowLevel Burial Grounds by September 2000.

Accelerate Readiness to Receive Spent Nuclear Fuel K Basin Sludge - Clear three sections of the T Plant Canyon deck in FY 2000 and complete entire deck clearing by FY 2001. Complete Project Execution Plan and Conceptual Design Document for removal of Shippingport Fuel from T Plant in FY 2000. Develop design requirements by September 2000 for acceptance of K Basin sludge at $\mathrm{T}$ Plant.

\section{Cost Performance $(\$ M):$}

\begin{tabular}{|l|c|c|c|}
\hline & BCWP & ACWP & VARIANCE \\
\hline Waste Management & $\$ 37.2$ & $\$ 37.9$ & $-\$ 0.7$ \\
\hline
\end{tabular}

The \$0.7 million (2 percent) unfavorable cost variance is within the established threshold. Further information at the PBS level can be found in the following Cost Variance Analysis details. 


\section{Schedule Performance ( $\$ M$ ):}

\begin{tabular}{|l|c|c|c|}
\hline & BCWP & BCWS & VARIANCE \\
\hline Waste Management & $\$ 37.2$ & $\$ 40.7$ & $-\$ 3.5$ \\
\hline
\end{tabular}

The \$3.5 million ( 9 percent) unfavorable schedule variance is primarily due to delays in TRU production and MLLW treatment. Further information at the PBS level can be found in the following Schedule Variance Analysis details.

FY 2000 Cost/SChedule Performance - All Fund Types Cumulative to Date Status - $(\$ 000)$

FYTD

By PBS

1.2.1 Solid Waste Storage

WM03 \& Disposal

1.2.2 Solid Waste

WM04 Treatment

1.2.3 Liquid Effluents -

WM05 200 Area

1.4 .2

TP02
WESF

Total

\begin{tabular}{llllllll}
\hline BCWS & BCWP & ACWP & SV & $\%$ & CV & $\%$ & PEM
\end{tabular}

$\begin{array}{llllllllllll}\$ 14,035 & \$ 13,828 & \$ & 13,081 & \$ & (207) & -1 \% & \$ & 748 & 5 \% & \$ & 36,395\end{array}$

$\$ 10,665 \$ 9,292 \$ 10,726 \$(1,374)-13 \% \$(1,434)-15 \% \$ 30,106$

$\begin{array}{llllllllllll}\$ 10,855 & \$ 9,657 & \$ & 9,348 & \$ & (1,199) & -11 \% & \$ & 309 & 3 \% & \$ & 29,267\end{array}$

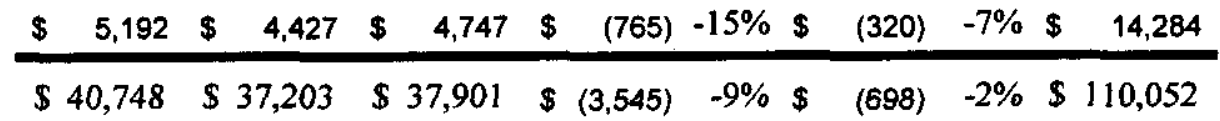




\section{Cost/Schedule Performance Indices \\ (FEBRUARY 2000 AND FYTD)}

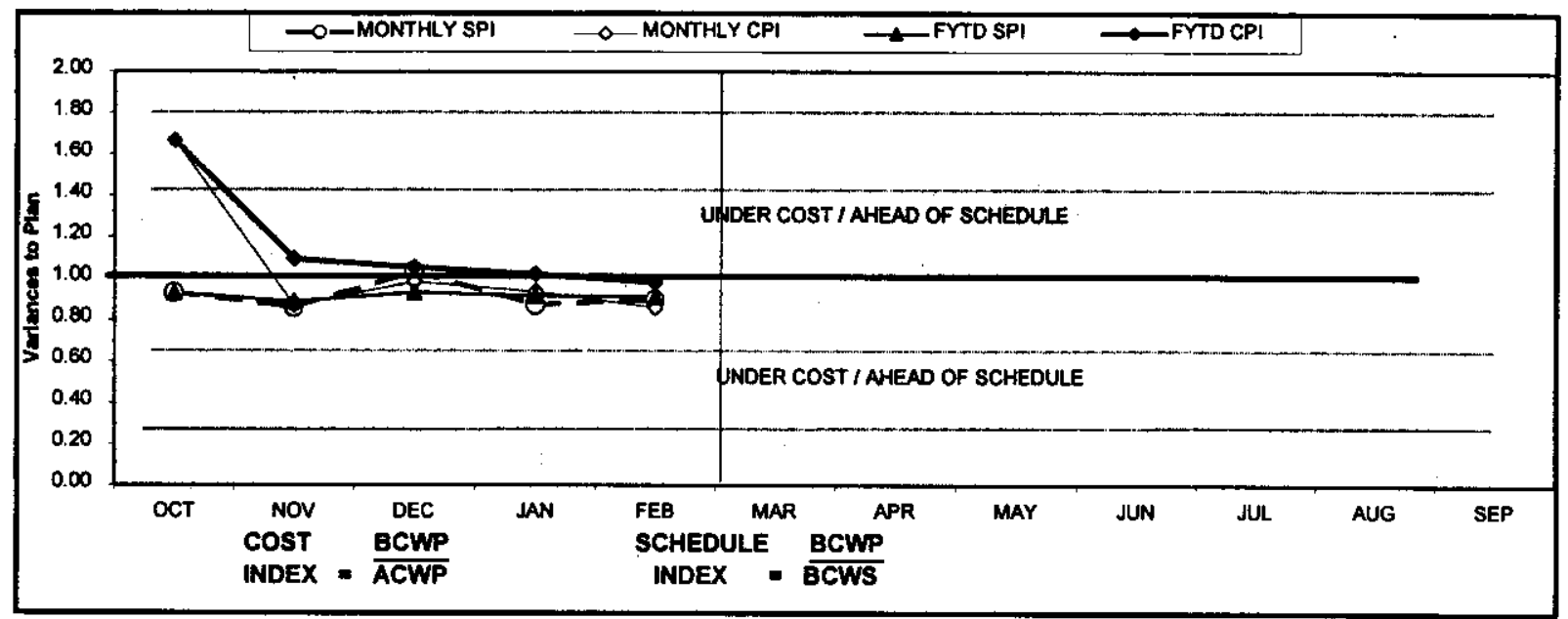

\begin{tabular}{|c|c|c|c|c|c|c|c|c|c|c|c|c|}
\hline 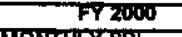 & OCT & Nov & LuZc & JAN & FE: & MAR & APR & IAY & JUN & JUL & AUU & SEP \\
\hline MONIRLYSP & 0.93 & 0.85 & 1.03 & 0.88 & 0.90 & & & & & & & \\
\hline MONTRCYCPI & 1.60 & 0.87 & 0.98 & 0.94 & 0.80 & & & & & & & \\
\hline FYIOSFI & 0.93 & 0.89 & 0.85 & 0.82 & 0.91 & & & & & & & \\
\hline FYTOCP & 7.60 & 1.09 & 1.05 & 5.02 & 0.89 & & & & & & & \\
\hline MONIHLY BCWS & 6,641 & 9,616 & 7,269 & E,331 & 8,691 & & & & & & & \\
\hline MONTRLY BCWP & 5,163 & 8,277 & 7,499 & 7,291 & 57,973 & & & & & & & \\
\hline MONIHLYACWP & 3,708 & 9,518 & 7,619 & 7,789 & 59,272 & & & & & & & \\
\hline FYTOBCWS & 6,641 & 76,257 & 523,526 & $\$ 31,857$ & 340,748 & & & & & & & \\
\hline FYTO'BCWP & 6,163 & 14,440 & 521,939 & 529,230 & $\$ 37,203$ & & & & & & & \\
\hline FYTDACWP & 3,703 & 13,221 & $\$ 20,840$ & $\$ 28,629$ & $\$ 37,901$ & & & & & & & \\
\hline
\end{tabular}

\section{COST VARIANCE ANALYSIS: $(-\$ 0.7 \mathrm{M})$}

\section{WBS/PBS}

\subsection{1/WM03}

1.2.1/WM threshold.

Impact: No impact.

Corrective Action: No corrective action required.

\subsection{2/WM04}

Title

Description/Cause: The unfavorable cost variance of $-\$ 1.4 \mathrm{M}(-15$ percent $)$ is due to scope being performed under an Advanced Work Authorization (AWA) for T Plant support to accelerated SNF sludge removal. In addition, there are retooling costs caused by the new WIPP permit changes.

Impact: No impact.

Corrective Action: A BCR has been drafted to reflect the additional workscope for T-Plant and the TRU Project.

\section{Solid Waste Storage \& Disposal}

\section{Solid Waste Treatment}




\subsubsection{1/WM05 Liquid Effluents}

Description/Cause: The favorable cost variance of $\$ 0.3 \mathrm{M}$ (3 percent) is within the established threshold.

Impact: No impact.

Corrective Action: No corrective action required.

\subsection{2/TP02 WESF}

Description/Cause: The unfavorable cost variance of $-\$ 0.3 \mathrm{M}(-7$ percent $)$ is caused by the UT testing and repair of the WESF stack.

Impact: No impact.

Corrective Action: The Carryover BCR will eliminate the UT testing variance. The stack repair will be managed in the Corrective Maintenance budget.

\section{Schedule Variance Analysis: (- \$3.5M)}

\section{WBS/PBS}

\subsection{1/ WM03}

Description /Ca established threshold.

Impact: No Impact.

Corrective Action: No corrective action required.

\subsection{2/ WMO4}

\section{Title}

Description /Cause: The unfavorable schedule variance of $-\$ 1.4 \mathrm{M}(-13 \%$ percent $)$ is due to the delay in TRU production and shipments, which is a result of WIPP permit changes and recertification. MLLW treatment is behind schedule due to ATG not completing construction on their facility as scheduled.

Impact: No Impact.

Corrective Action: ATG processing began in late December, 1999. The schedule will be recovered. TRU production is in the process of rebaselining to resolve WIPP certification audit comments and reworking the shipment schedule.

\subsubsection{1/ WM05 Liquid Effluents}

Description /Cause: The unfavorable schedule variance of $-\$ 1.2 \mathrm{M}(-11 \%$ percent $)$ is due to ETF not operating as planned in January due to groundwater receipt ceasing.

Impact: No Impact.

Corrective Action: The production schedule is being updated to accommodate UP-1 groundwater input changes and increased 242-A volumes.

\subsection{1/ TP02}

WESF

Description /Cause: The unfavorable schedule variance of $-\$ 0.8 \mathrm{M}(-15 \%$ percent) is due to the deferral of the FSAR to FY 2002 to resolve DOE funding reductions.

Impact: No Impact.

Corrective Action: A BCR has been submitted to defer the FSAR. 


\section{ISSUES}

\section{Technical Issues}

Nothing to report at this time.

\section{DOE/Regulator/External Issues}

The Waste Management Programmatic Environmental Impact Statement (PEIS) was issued on February 25, 2000. The Records of Decision (ROD) for LLW and MLLW will affect Hanford's disposal role for the Complex. The ROD outcomes may have a significant impact on disposal volumes and rates at Hanford.

Certification of Hanford's TRU Project is necessary to initiate waste shipment to WIPP. Continue working with the Carlsbad Area Office, the Environmental Protection Agency and the New Mexico Environment Department to achieve WIPP certification of Hanford's TRU Project and initiate waste shipment to WIPP.

Baseline Change Requests Currently in Process $(\$ 000)$

\begin{tabular}{|c|c|c|c|c|c|c|c|c|c|}
\hline $\begin{array}{l}\text { PROJECT } \\
\text { CHANGE } \\
\text { NUMBER }\end{array}$ & $\begin{array}{l}\text { DATE } \\
\text { ORIGIN. }\end{array}$ & BCR TITLE & $\begin{array}{l}\text { FYOO COST } \\
\text { IMPACT \$OOO }\end{array}$ & SCH & TECH & $\begin{array}{l}\text { DATE } \\
\text { TO CCB }\end{array}$ & $\begin{array}{c}\text { CCB } \\
\text { APR'VD }\end{array}$ & $\begin{array}{c}\mathbf{R L} \\
\text { APRVD }\end{array}$ & CURRENT \\
\hline $\begin{array}{l}\text { WM-2000-002 } \\
\text { FSP-2000-007 } \\
\text { FSP-2000-018 } \\
\text { WM-2000-003 } \\
\text { WM-2000-004 }\end{array}$ & $\begin{array}{c}1 / 5 / 00 \\
12 / 2 / 99 \\
1 / 25 / 00 \\
\\
2 / 8 / 00 \\
2 / 8 / 00\end{array}$ & $\begin{array}{l}\text { Wandated Funds Reduction } \\
\text { WESF FY } 1999 \text { Carryover } \\
\text { WESF Mandated Funds Reduction } \\
\text { T-Plant Canyon Deck Clean off and } \\
\text { PWR Fuel Removal } \\
\text { WMP Stretch Goals }\end{array}$ & $\begin{array}{c}-\$ 3,042 \\
\$ 160 \\
-\$ 1,100 \\
\text { TBD } \\
\$ 0\end{array}$ & $\begin{array}{l}\mathbf{x} \\
\mathbf{x}\end{array}$ & $\begin{array}{l}x \\
x\end{array}$ & $\begin{array}{c}02 / 17 / 00 \\
01 / 14 / 00 \\
02 / 29 / 00 \\
\text { TBD } \\
\text { TBD }\end{array}$ & $\begin{array}{l}01 / 14 / 00 \\
02 / 29 / 00\end{array}$ & $02 / 11 / 00$ & $\begin{array}{l}\text { Pending } \\
\text { Approved } \\
\text { At DOE-RL } \\
\text { Draft in Review } \\
\text { withDOE-RL } \\
\text { In Draft }\end{array}$ \\
\hline \multicolumn{10}{|c|}{ ADVANCE WORK AUTHORIZATIONS } \\
\hline $\begin{array}{l}\text { AWA } \\
\text { AWA }\end{array}$ & $\begin{array}{l}2 / 24 / 00 \\
2 / 25 / 00\end{array}$ & $\begin{array}{l}\text { TPlant Canyon Deck cleanout/PW } \\
\text { TRU Retrieval }\end{array}$ & $\begin{array}{l}31,150^{\circ} \\
\$ 165\end{array}$ & $\begin{array}{l}\mathrm{X} \\
\mathrm{X}\end{array}$ & & & & $\begin{array}{l}02 / 25700 \\
02 / 25 / 00\end{array}$ & $\begin{array}{l}\text { Acceleration of scope } \\
\text { Acceleration of scope }\end{array}$ \\
\hline
\end{tabular}

\section{WASTE MANAGEMENT - WBS 1.2 Milestone ACHIEVEMENT}

\begin{tabular}{|c|c|c|c|c|c|c|c|c|}
\hline \multirow[b]{2}{*}{ MILESTONE TYPE } & \multicolumn{4}{|c|}{ FISCAL YEAR-TO-DATE } & \multicolumn{3}{|c|}{ REMAINING SCHEDULED } & \multirow[b]{2}{*}{$\begin{array}{l}\text { TOTAL } \\
\text { FY } 2000\end{array}$} \\
\hline & $\begin{array}{l}\text { Completed } \\
\text { Early }\end{array}$ & $\begin{array}{l}\text { Completed } \\
\text { On Schedule }\end{array}$ & $\begin{array}{l}\text { Completed } \\
\text { Late }\end{array}$ & Overdue & $\begin{array}{c}\text { Forecast } \\
\text { Early }\end{array}$ & $\begin{array}{c}\text { Forecast On } \\
\text { Schedule }\end{array}$ & Forecast Late & \\
\hline Enforceable Agreement & 1 & 0 & 0 & 0 & $\overline{0}$ & 1 & 0 & 2 \\
\hline DOE-HQ & $\overline{0}$ & 0 & 0 & 0 & $\overline{0}$ & 0 & 0 & 0 \\
\hline$\overline{\mathbf{R L}}$ & $\overline{0}$ & 0 & 0 & 0 & $\overline{0}$ & 9 & 0 & $\overline{9}$ \\
\hline Total Project & 1 & 이 & 0 & 0 & 0 & 10 & 0 & 11 \\
\hline
\end{tabular}


Tr-Pary Agrement 1 CA Mriestones

\begin{tabular}{|l|l|l|}
\hline \multicolumn{1}{|c|}{ Number } & \multicolumn{1}{|c|}{ Milestone Title } & \multicolumn{1}{c|}{ Status } \\
\hline $\begin{array}{l}\text { M-91-03 } \\
\text { WMH-00- } \\
\text { 001) }\end{array}$ & $\begin{array}{l}\text { Issue TRU/TRUM Waste } \\
\text { PMP }\end{array}$ & due 06/30/00 - On schedule (stretch) \\
\hline $\begin{array}{l}\text { M-91-04 } \\
\text { (A2J-00- }\end{array}$ & $\begin{array}{l}\text { Complete Construction of } \\
\text { CH TRU/TRUM } \\
\text { Retrieval Facility }\end{array}$ & $\begin{array}{l}\text { due 09/29/00 - DOE-RL issued a letter to } \\
\text { Ecology on February 29, 2000 documenting } \\
\text { closure of the TPA milestone as retrieval has been } \\
\text { initiated and is planned to continue, even without } \\
\text { construction of Project W-113 facilities. }\end{array}$ \\
\hline & & \\
\hline & Nothing to report & \\
\hline
\end{tabular}

\section{MILESTONE EXCEPTION REPORT}

Number/NWBS Level

Milestone Title

Baseline

Date

Forecast

Date

\section{OVerdue - 0}

\section{FORECAST LATE - 0}

\section{FY 1999 OVERDUE - 1}

\section{TRP-98-709 RL \\ Complete Hot Cell Deactivation \\ $03 / 31 / 99$ \\ $09 / 30 / 00$ \\ 1.4.2 \\ WESF Facility (A-E)}

Cause: This milestone is not complete due to not being supported at the current funding level.

Impact: No overall impact is expected.

Corrective Action: Return-on Investment (ROI) funding has been identified for this work scope and a new forecasted completion date of September 30, 2000 established. 


\section{Performance Objectives MLLW TREATMENT}
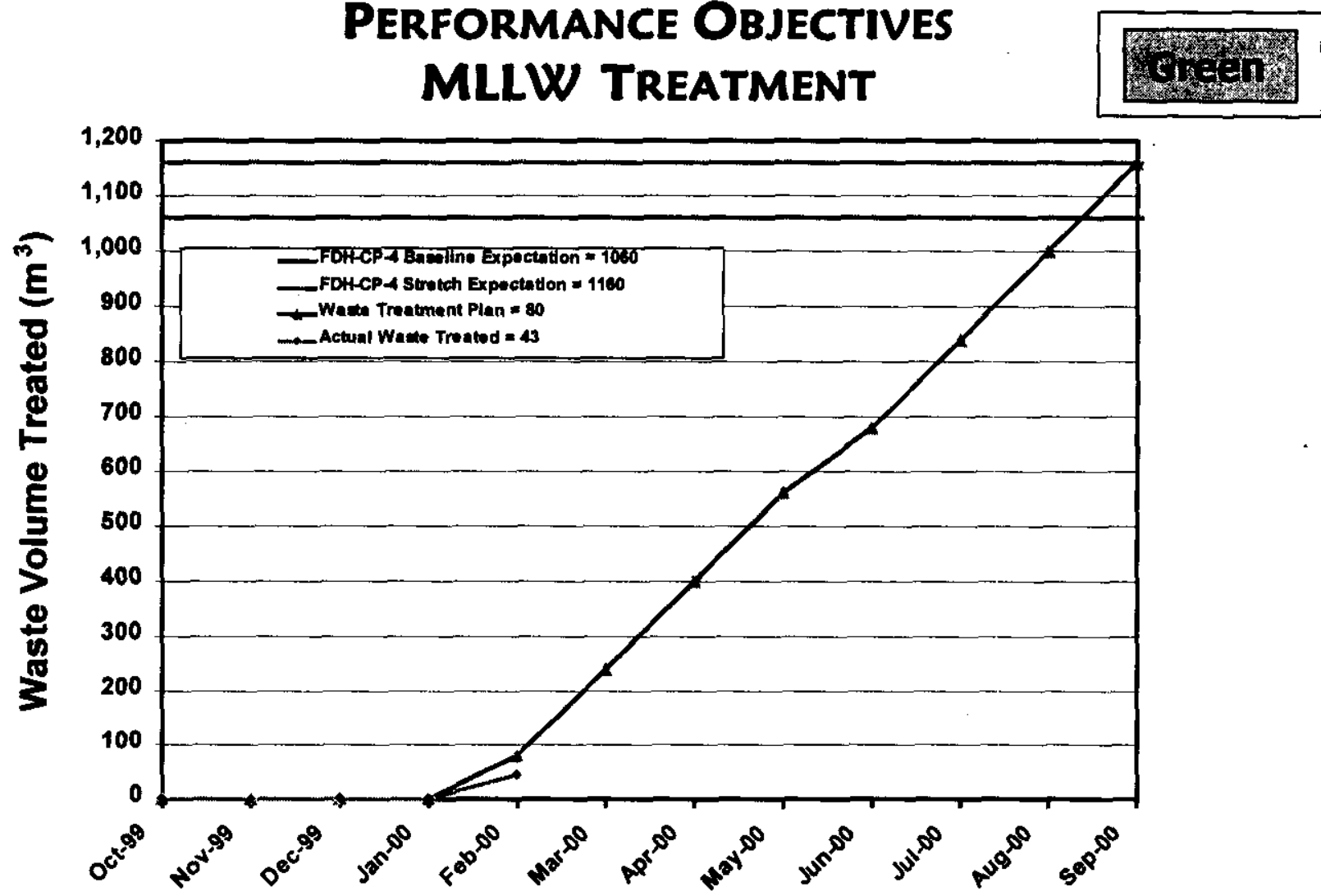

Action Plans: Ramping-up to meet stretch expectation.

MLLW Disposal

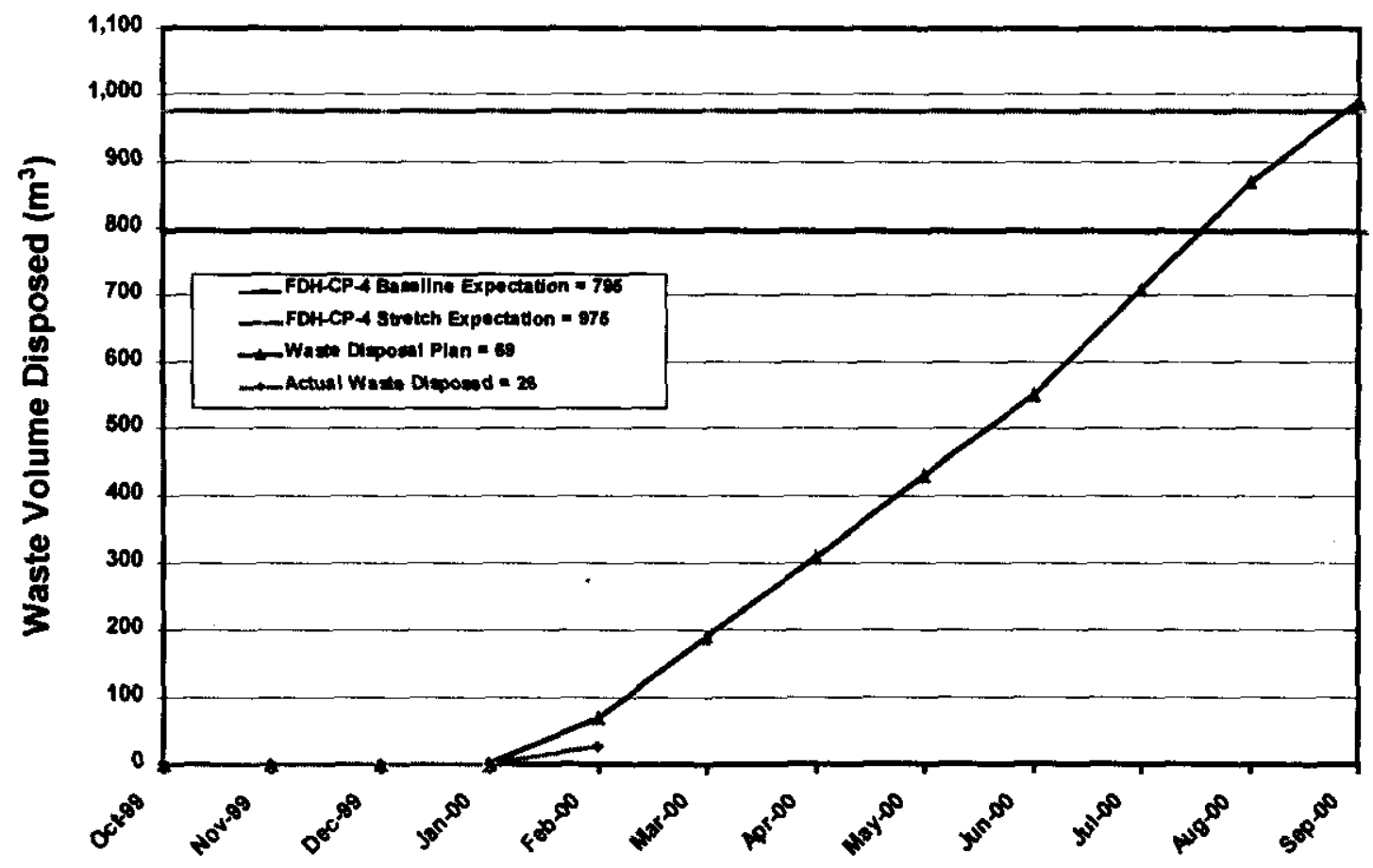

Action Plans: Ramping-up to meet the baseline expectation. 


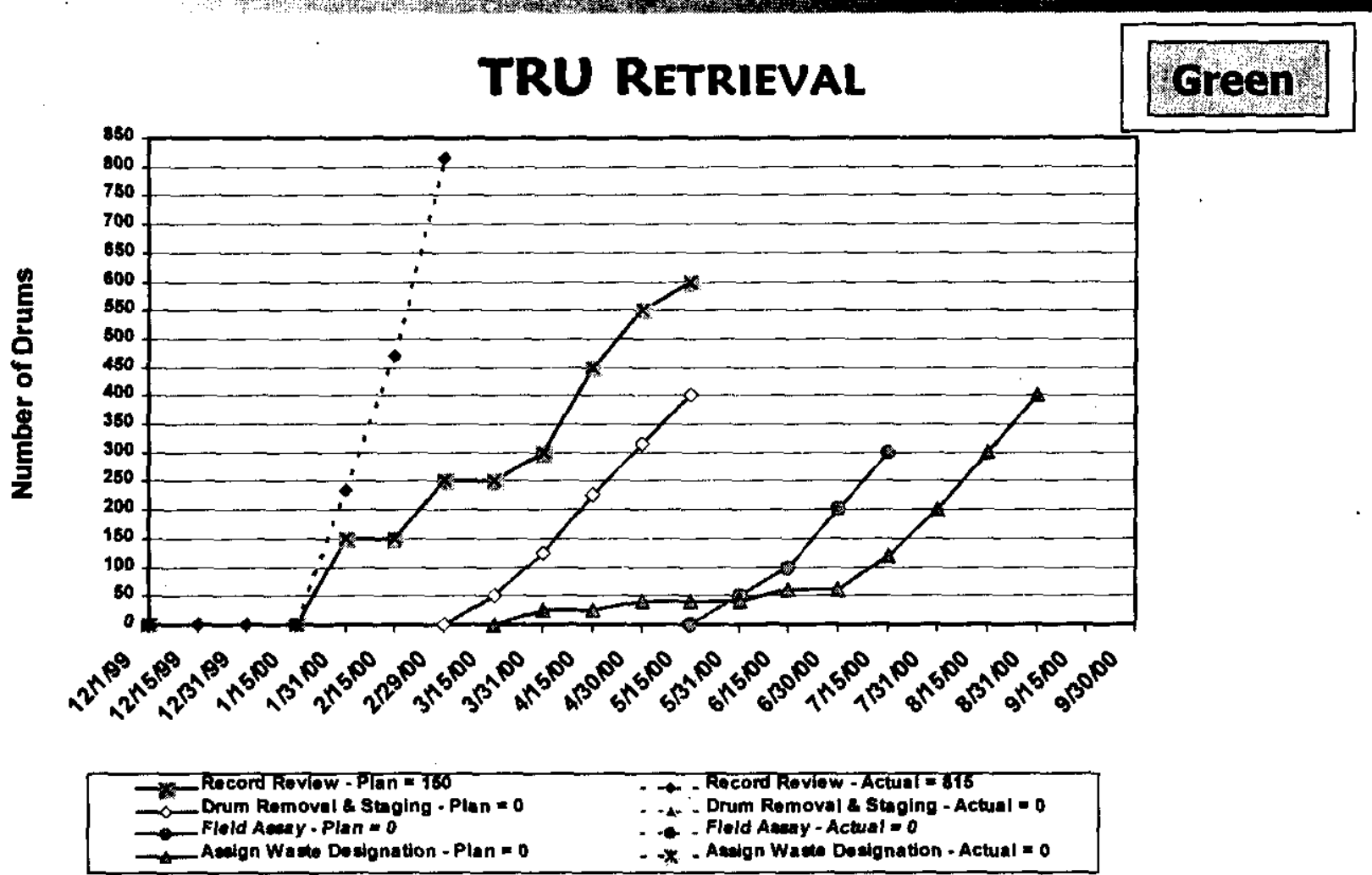

Action Plans: On track. Completed over 800 document reviews through February. Field retrieval activities are planned to start in late March, which includes removing the drums from the stack, performing container inspections, and completing radiological surveys. Negotiating additional super-stretch incentives with DOE-RL.

\section{TRU CONTAINER ProCessing}
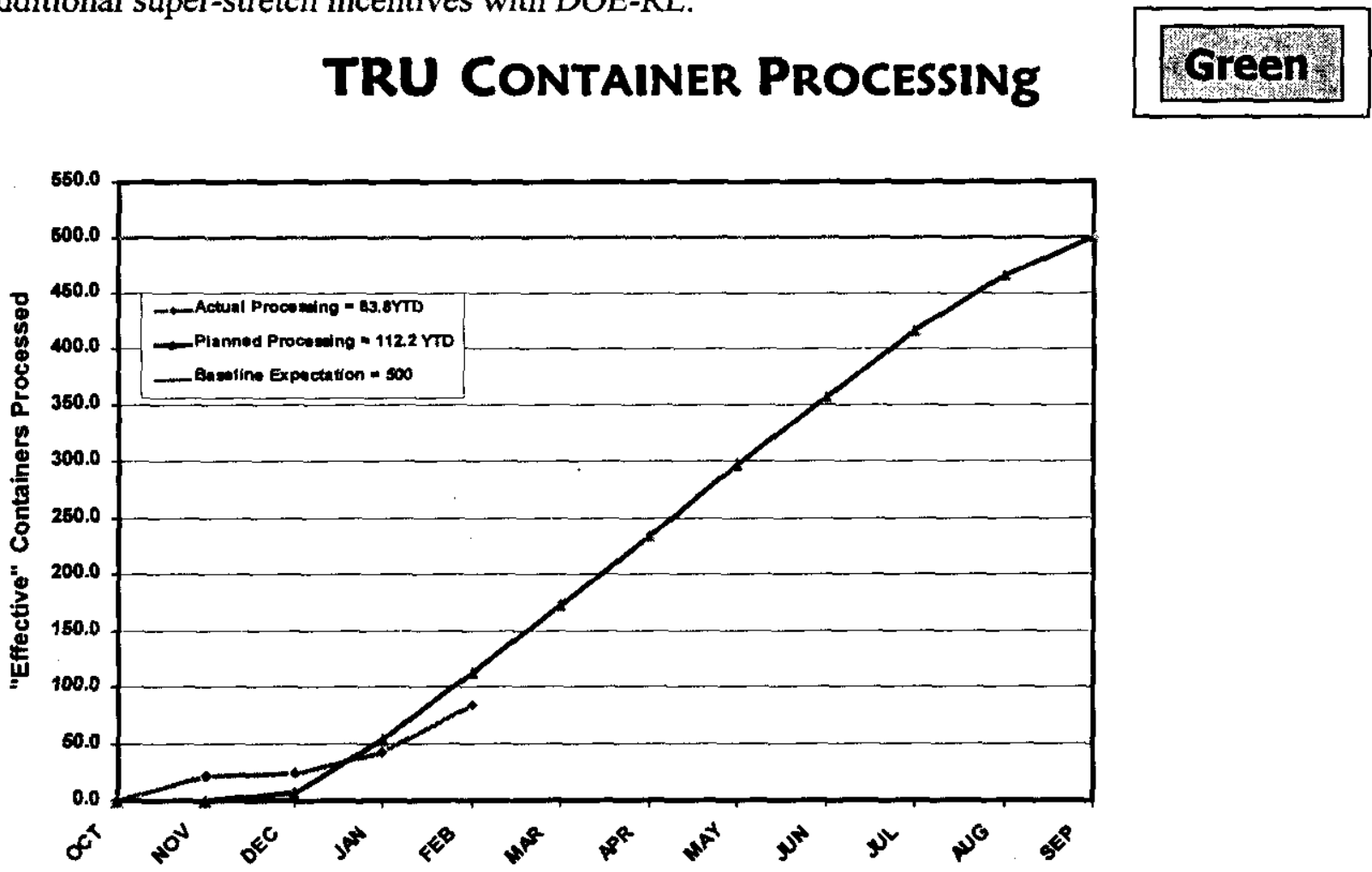

Action Plans: On track to meet the baseline expectation. 
TRU SHIPMENTS

Yellow

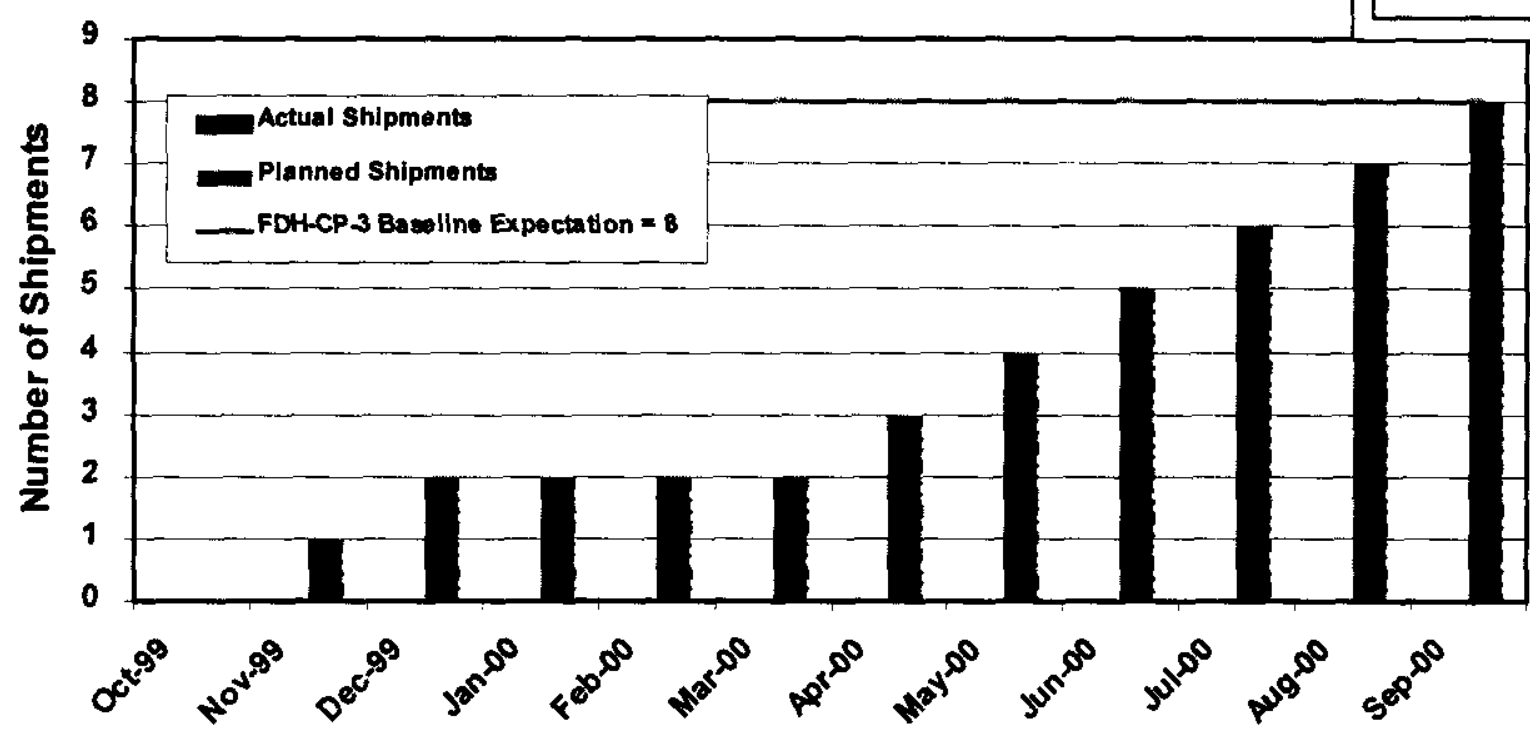

Action Plans: Change required based on additional CAO WIPP Certification requirements. Initial shipment delayed until spring 2000.

\section{Liquid Waste Processing}
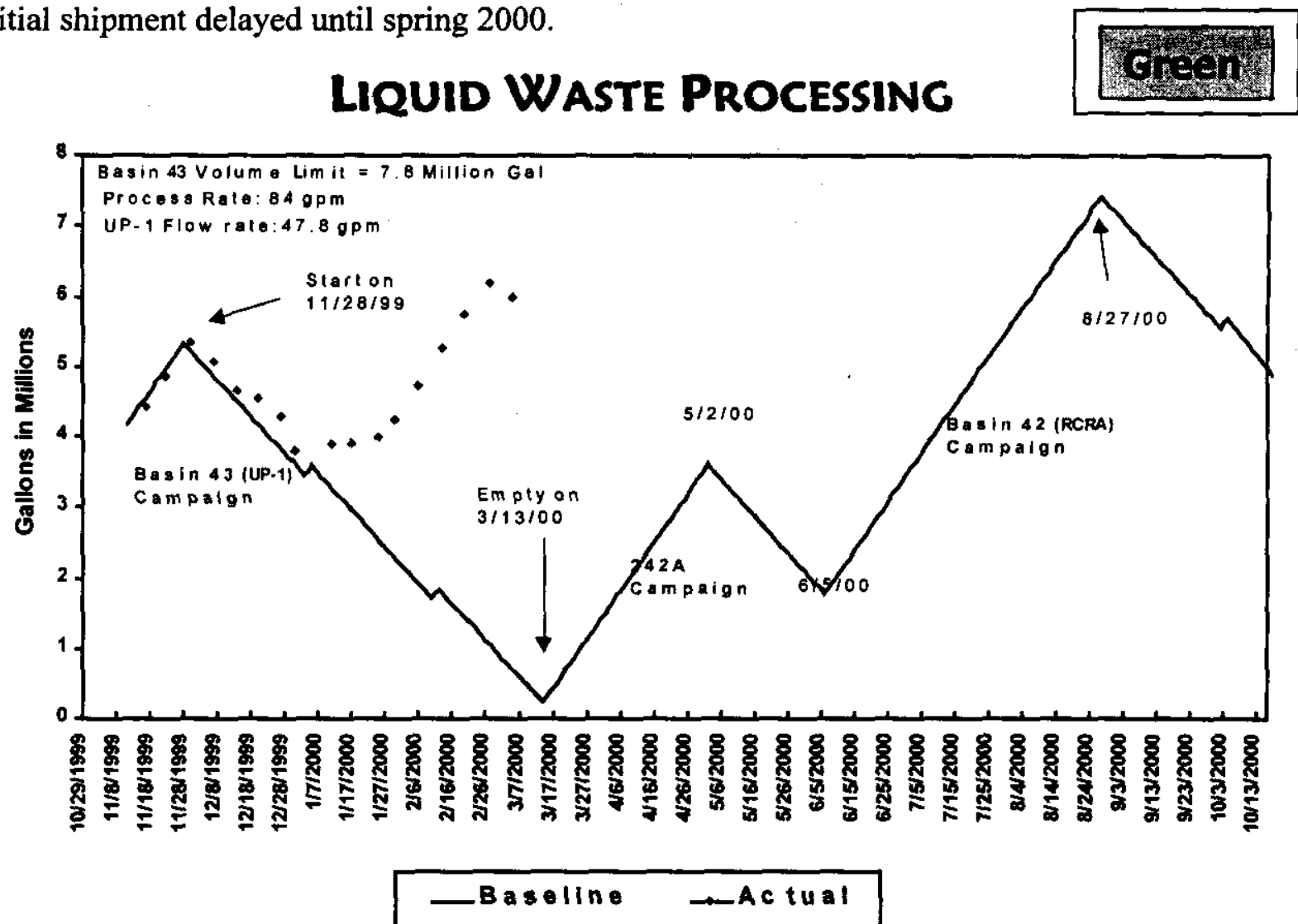

Action Plans: BHI shut down 200-UP-1 groundwater on 12/27/99 and restarted on 1/26/00. Plant was shut down during January and has restarted to reduce the 200-UP-1 inventory. Production plans will be adjusted when DOE-RL direction is obtained to support incremental 242A Evaporator operations. 


\section{KEY INTEGRATION ACTIVITIES}

- $\quad$ Preparing T Plant to receive Spent Nuclear Fuel K Basin sludge.

- Issuance of Records of Decision for LLW and MLLW is expected to affect Hanford's role in disposing of waste from other sites. Hanford's role as one of the identified LLW/MLLW disposal sites for the Complex is yet to be fully defined. Working with DOE-RL, DOE-HQ and other Sites to develop and define role.

- $\quad$ Support continued UP-1 Groundwater treatment and increased RPP evaporator feed volumes.

- $\quad$ Support River Corridor Project in cleanup and removal of waste from 324 and 327 buildings.

- $\quad$ Support DOE-RL declaration of Readiness-to-Proceed in support of the Office of River Protection (ORP) Privatization contract.

- Working with PNNL, EM 50 and Mixed Waste Focus Area (MWFA) to obtain funding in support of the M-91 Facility Project.

- Participated in the DOE Order 435.1 workshop with other DOE and Contractor site representatives to share issues, lessons learned, and paths forward in complying with the Order.

- Continue to work with DOE- RL, -Oakland, and -Ohio to support resolution of TRU small quantity site disposition issues. 

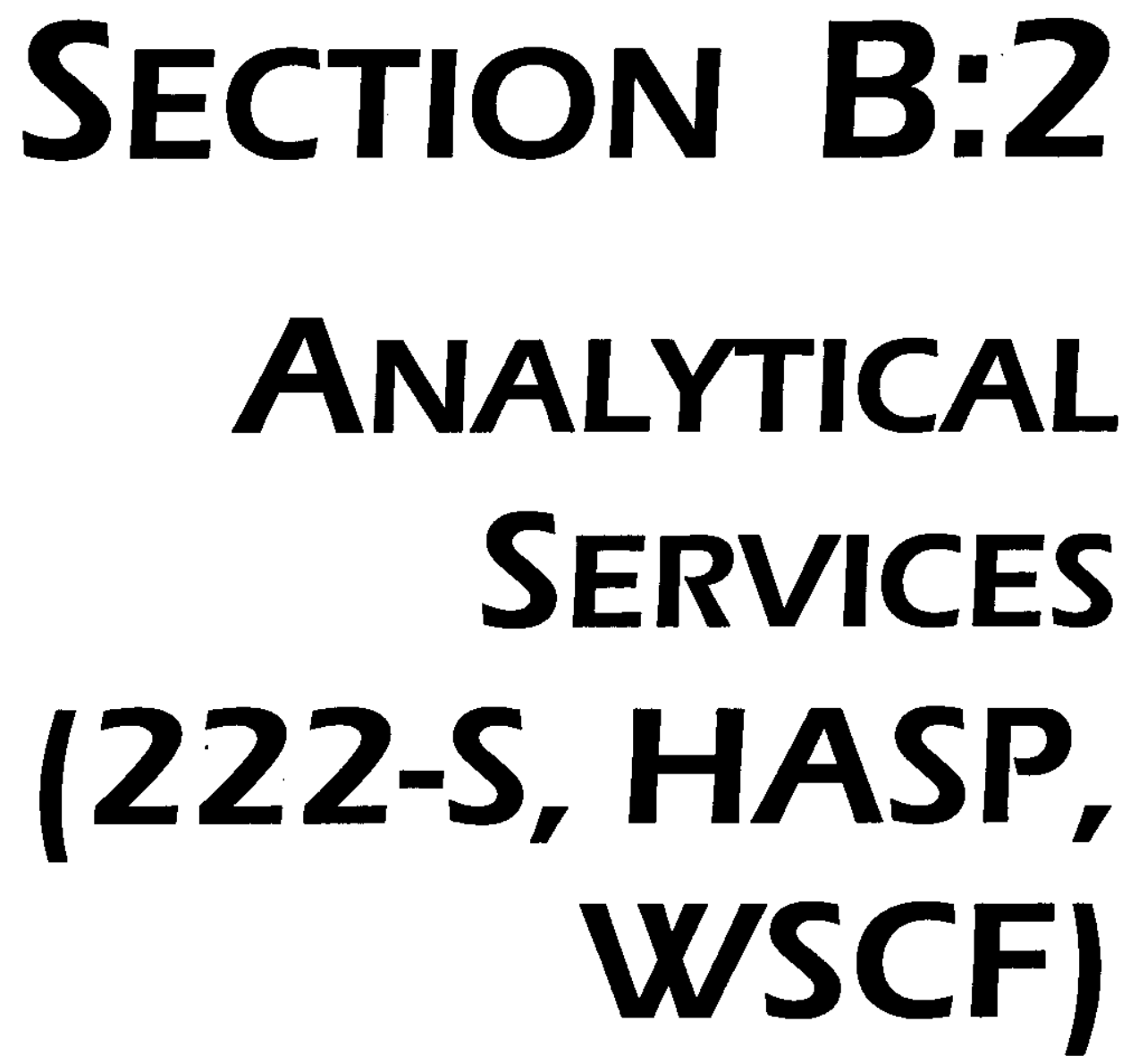

PROJECT MANAGERS

\author{
S. H. Wisness, RL \\ Phone: (509) 373-9337 \\ D.L. Renberger, FH \\ Phone: (509) 372-0877
}




\section{SUMMARY}

Analytical Services [222-S, Hanford Analytical Services Program (HASP), Waste Sampling and Characterization Facility (WSCF)] consists of Analytical Services, PBS WM06, WBS 1.2.4.

NOTE: Unless otherwise noted, the Safety, Conduct of Operations, and Cost/Schedule data contained herein is as of February 29, 2000. Other information is updated as noted.

Fiscal-year-to-date-milestone performance (EA, DOE-HQ and RL) shows no milestones are due this reporting period.

\section{ACCOMPLISHMENTS}

- February and March analytical output has been high, with a total of 4.0 AEUs processed at the 222-S Laboratory through March 3, 2000 in support of the RPP (TWRS) tank characterization program as planned. Completed the report on AZ-102 on February 11, 2000 and the grab sample analysis and report on AP-107 on February 29, 2000, both as planned. Three additional reports (AP-107, ER-311, and AY-102) were released in early March 2000. A total of 5.3 AEUs have been processed through March 24, 2000 out of the required 11 for the year.

- $\quad$ Procedures, methods, equipment, and training all had to be significantly revised to meet the new WIPP permit from the State of New Mexico. All these changes had to be done rapidly to meet overall project audit and shipment schedules. Performed 7,500 analyses (FYTD) through February 2000 at WSCF for a wide variety of customers as planned. Through March 24, 2000, 8,700 analyses have been completed at WSCF.

- $\quad$ Completed the Facility Evaluation Board audit at the 222-S and WSCF laboratories in January 2000. The final FEB report was issued in February 2000 with improvements in 9 of 10 areas and an overall rating of " 3 ".

\section{SAFETY}

Although a small organization (a single case generates a high case per hour figure), the three recent (April, November and December 19.99) Lost Away Workday cases should be examined closely as they reflect a significant increase over previous history. Analytical Services had no lost away cases during January and February 2000. The project will continue to refocus on safety and personal and team accountability. The four-month trend is a positive indication for performance during the second half of FY 2000.

There were no new OSHA recordable cases in February. 


\section{Lost Away Workday Case Rate}

Project Safe Hours $=97,494$

FY $1999=0.4$

FY 2000 to date $=1.6$

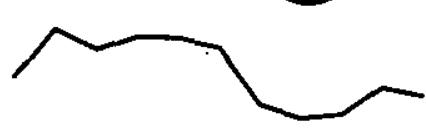

Average $=1.4$

$6 \quad \begin{gathered}1,600,000 \text { hours without } \\ \text { a Lost Away Work Day Case } \\ \text { (Oct 96 - Apr 99) }\end{gathered}$

2

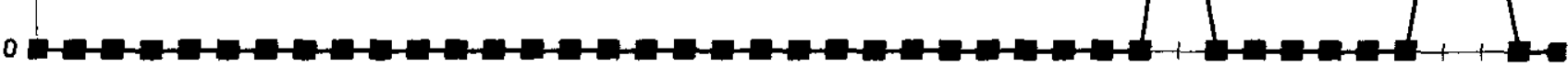
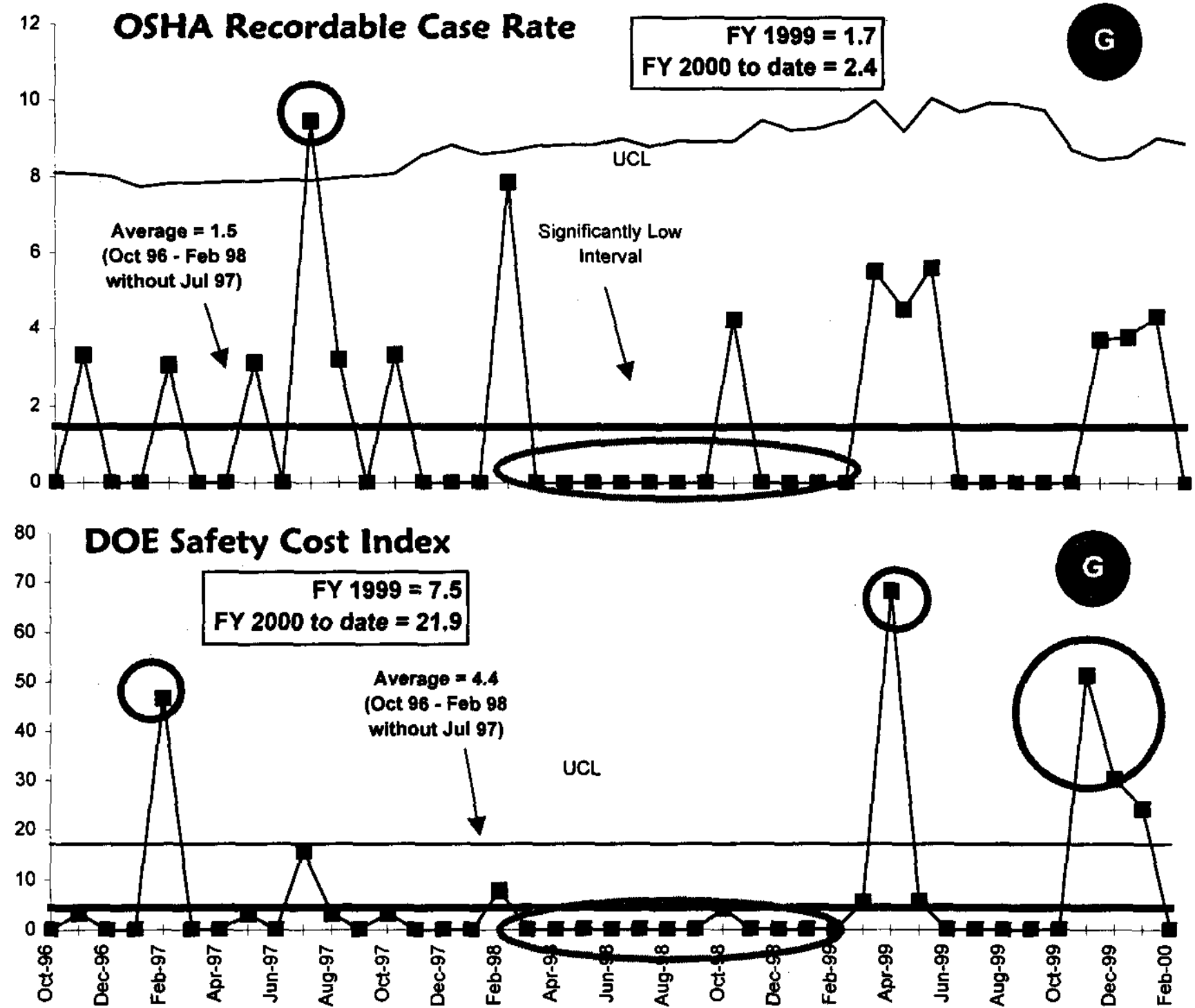


\section{CONDUCT OF OPERATIONS / ISMS STATUS CONDUCT OF OPERATIONS}

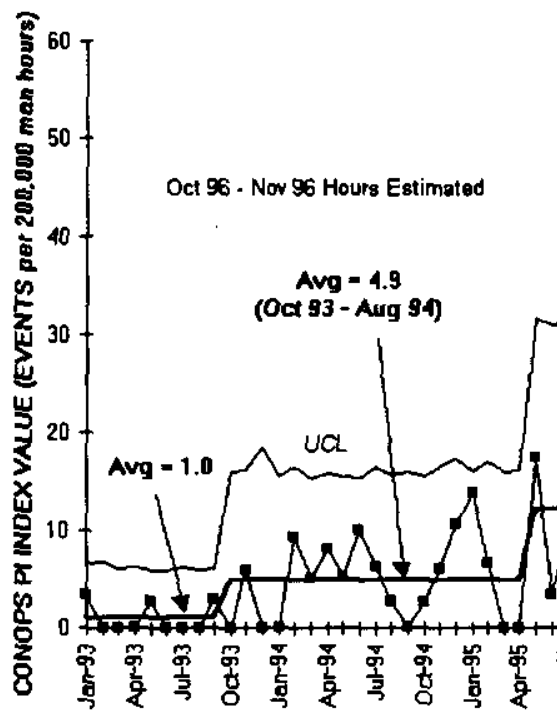

$$
\begin{array}{r}
\text { FY } 1999=18.3 \\
\text { Fr } 2000 \text { to date }=8.8
\end{array}
$$

Significant Increase

FY 2000 to date $=8.8$

November 1998

$$
\text { Avg }-12.1
$$

(May 95 - Dec 95)

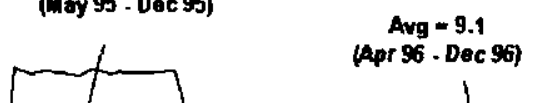

(Apr 96. Dec 96)

\section{ISMS STATUS}

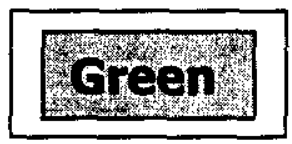

Analytical Services ISMS status is included in the Waste Management Project Section of this report. Overall, on track for the May 2000 verification with a need to improve employee involvement.

\section{BREAKTHROUGHS / OPPORTUNITIES FOR IMPROVEMENT}

No breakthroughs or opportunities for improvement were identified at this time.

\section{UPCOMING ACTIVITIES}

WIPP Certification and Waste Shipments -- Staff is expediting analytical work and data reports to provide additional qualified drums for shipment to WIPP. Potential issues with some prior sampled drums make this a necessity.

242A Evaporator Operations - Due to inadequate feed material from tank farms, expedited analysis of a second tank is underway to support the planned April 2000 campaign. 
ORP Readiness to Proceed - It has been determined that Analytical Services is prepared to support the readiness to proceed decision for the BNFL contract. Key follow-up actions are:

- $\quad$ Formal specification of requirements from ORP to RL and then to FH

- Stable funding of needed equipment and facility repair in Multi-Year Work Plans (RL and ORP)

- $\quad$ Funding replacement of obsolete laboratory support systems (Information Management)

- Funding of staff to maintain core competency.

\section{Cost Performance (\$M):}

\begin{tabular}{|l|c|c|c|}
\hline & BCWP & ACWP & VARIANCE \\
\hline Analytical Services & $\$ 10.8$ & $\$ 11.5$ & $-\$ 0.7$ \\
\hline
\end{tabular}

The $\$ 0.7$ million ( 7 percent) unfavorable cost variance is due to increased cost for 222-S Laboratory polychlorinated biphenyl recovery and increased resources required to support compliance issues.

\section{Schedule Performance (\$M):}

\begin{tabular}{|l|c|c|c|}
\hline & BCWP & BCWS & VARIANCE \\
\hline Analytical Services & $\$ 10.8$ & $\$ 11.1$ & $-\$ 0.3$ \\
\hline
\end{tabular}

The $\$ 0.3$ million ( 3 percent) unfavorable schedule variance is within the established threshold.

\section{FY 2000 Cost/Schedule Performance - All Fund Types Cumulative to Date Status - $(\$ 000)$

\author{
FYTD
}

By PBS

\begin{tabular}{lllllll}
\hline BCWS & BCWP & ACWP & SV & $\%$ & CV & $\%$
\end{tabular}

PEM

WBS

1.2.4 Analytical

WM06 Services $\$ 11,080 \quad \$ 10,797 \quad \$ 11,506 \quad \$(283) \quad-3 \% \quad \$(709) \quad-7 \% \quad \$ 27,752$

Total $\quad \begin{array}{lllllllllll}\$ 11,080 & \$ 10,797 & \$ 11,506 & \$(283) & -3 \% & \$(709) & -7 \% & \$ 27,752\end{array}$ 


\section{COST/SCHEDUle PERformanCe INDICES (FEBRUARY 2000 AND FYTD)}

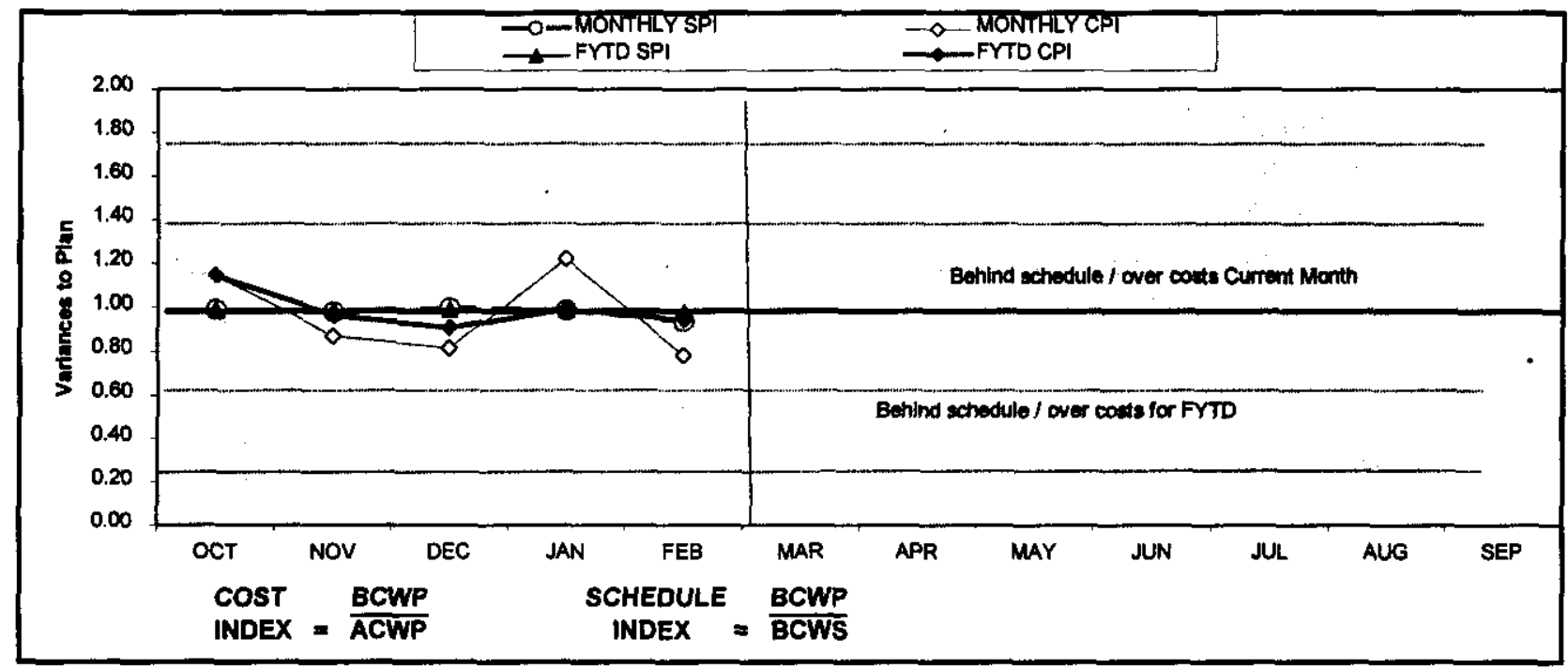

\begin{tabular}{|c|c|c|c|c|c|c|c|c|c|c|c|c|}
\hline FY:OLOH & OCT & NoV & DEC & JAAN & FEB & MAR & APF & TWAY & JUN & JUL & AUS & SEF \\
\hline MONIRILYSTI & 0.99 & 0.88 & 0.99 & 0.90 & 0.94 & & & & & & & \\
\hline MONIFLY CPI & 7.14 & 0.87 & 0.81 & 1.22 & 0.78 & & & & & & & \\
\hline FYTDSP & 0.99 & 0.98 & 0.99 & 0.98 & 0.97 & & & & & & & \\
\hline FYIOCPI & 1.14 & 0.96 & 0.91 & 0.99 & 0.94 & & & & & & & \\
\hline MONIHLYECWS & $\$ 1,568$ & $7+2,3410$ & 31,973 & 32,696 & $\$ 2,283$ & & & & & & & \\
\hline WONIRLY ECWP & 31,566 & 32,288 & $\$ 1,961$ & $\$ 2,847$ & 32,135 & & & & & & & \\
\hline MONIHLY ACWP & 71,369 & $\$ 2,640$ & $\$ 2,414$ & $\$ 2,342$ & $\$ 2,741$ & & & & & & & \\
\hline FYTDECWS & $\$, 588$ & $\$ 3,928$ & 35,901 & $\$ 6,797$ & $\$ 11,080$ & & & & & & & \\
\hline FYIDBCWP & 35,565 & $\$ 3,854$ & $\$ 5,815$ & $\$ 8,662$ & $\$ 10,797$ & & & & & & & \\
\hline FYTOACWP & 31,369 & 7,009 & $\$ 6,423$ & $\$ 8,765$ & $\$ 11,506$ & & & & & & & \\
\hline
\end{tabular}

\section{Cost Variance Analysis: ( $\$ 0.7 \mathrm{M})$}

\section{WBS/PBS}

\subsection{4/WM06}

\section{Title}

\section{Analytical Services}

Description/Cause: The unfavorable cost variance is of $\$ 0.7$ million (6.6 percent) is due to increased costs for 222-S Tank 104 poly-chlorinated biphenyl recovery activities; increased resources in support of compliance issues, ISM implementation, corrective action management, and chemical technologist training development.

Impact: Current yearend spending projections indicate a $\$ 1.0 \mathrm{M}$ overrun.

Corrective Action: Corrective actions have been identified and implemented to control spending to available funds. However, further actions are required. Management will continue to monitor costs and recommend potential areas where costs can be reduced to avoid exceedence of funding thresholds. 


\section{Schedule Variance Analysis: (- \$0.3M)}

\section{WBS/PBS}

1.2.4/WM06

Title

\section{Analytical Services}

Description /Cause: The unfavorable schedule variance of $\$ 0.3 \mathrm{M}$ (2.6 percent) is within established threshold.

Impact: None

Corrective Action: None required.

\section{ISSUES}

\section{Technical Issues}

Issues were self-identified in the WSCF laboratory's conformance to certain customer's (200 ETF, 300 TEDF) permit-mandated regulatory protocols (sample digestion, holding times and accreditation status). Impacts could be discharge permit violation depending on the type of samples. A regulatory penalty is unlikely. Corrective actions are being taken in each area and customers have been notified to enable impact assessment. Rework of all useable archived samples are complete.

\section{DOE/Regulator/External Issues}

CAO Audit of TRU Project - Complete actions to sustain field audit and support waste shipment to WIPP. Complete laboratory support required for headspace gas sampling and analysis.

\section{Baseline Change Requests Currently in Process (\$000)}

\begin{tabular}{|c|c|c|c|c|c|c|c|c|c|}
\hline $\begin{array}{c}\text { PROJECT } \\
\text { CHANGE NUMBER } \\
\end{array}$ & $\begin{array}{l}\text { DATE } \\
\text { ORIGIN. }\end{array}$ & BCR TITLE & $\begin{array}{c}\text { FYOO COST } \\
\text { IMPACT } \\
\$ 000\end{array}$ & SCH & TECH & $\begin{array}{l}\text { DATE } \\
\text { TO CCB }\end{array}$ & $\begin{array}{c}\text { CCB } \\
\text { APRVO }\end{array}$ & RL APRVD & CURRENT STATUS \\
\hline WM-2000-002 & $1 / 3 / 00$ & $\begin{array}{l}\text { Waste Management FY } 2000 \\
\text { Mandated Funds Reductions }\end{array}$ & .878 .50 & & & $2 / 17 / 00$ & & & $\begin{array}{l}\text { BCR submitted } \\
\text { to RL for review } \\
\text { and approval. }\end{array}$ \\
\hline \multicolumn{10}{|c|}{ ADVAINCE WORK AUTHORIZATIONS } \\
\hline & & Nothing to report. & & & & & & & \\
\hline
\end{tabular}




\section{ANALYTICAL SERVICES - WBS 1.2.4 MILESTONE ACHIEVEMENT}

\begin{tabular}{|c|c|c|c|c|c|c|c|c|}
\hline \multirow[b]{2}{*}{ MILESTONE TYPE } & \multicolumn{4}{|c|}{ FISCAL YEAR-TO-DATE } & \multicolumn{3}{|c|}{ REMAINING SCHEDULED } & \multirow[b]{2}{*}{$\begin{array}{c}\text { TOTAL } \\
\text { FY } \\
2000\end{array}$} \\
\hline & $\begin{array}{c}\text { Completed } \\
\text { Early }\end{array}$ & $\begin{array}{c}\text { Completed } \\
\text { On } \\
\text { Schedule }\end{array}$ & $\begin{array}{c}\text { Completed } \\
\text { Late }\end{array}$ & Overdue & $\begin{array}{c}\text { Forecast } \\
\text { Early }\end{array}$ & $\begin{array}{c}\text { Forecast } \\
\text { On } \\
\text { Schedule }\end{array}$ & $\begin{array}{l}\text { Forecast } \\
\text { Late }\end{array}$ & \\
\hline Enforceable Agreemen & 의 & 0 & 0 & 0 & 0 & 0 & 0 & \\
\hline DOE-HQ & 0 & 0 & 0 & 0 & $\underline{0}$ & 0 & 0 & \\
\hline $\mathrm{FO}$ & 0 & 0 & 0 & 0 & $\overline{0}$ & 0 & 0 & \\
\hline $\mathbf{R L}$ & 0 & 0 & 0 & 0 & $\underline{0}$ & 1 & 0 & \\
\hline Total Project & 0 & 0 & 0 & 0 & 0 & 1 & 0 & \\
\hline
\end{tabular}

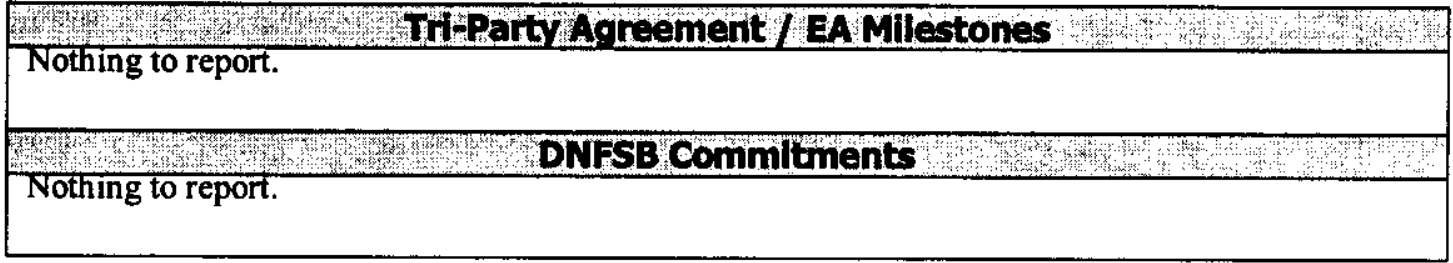

\section{MILESTONE EXCEPTION REPORT}

$\begin{array}{lll}\text { Number/WBS Level } & \text { Milestone Title } & \begin{array}{l}\text { Baseline } \\ \text { Date }\end{array}\end{array}$

ForecAst LATE - 0 


\section{Performance Objectives}

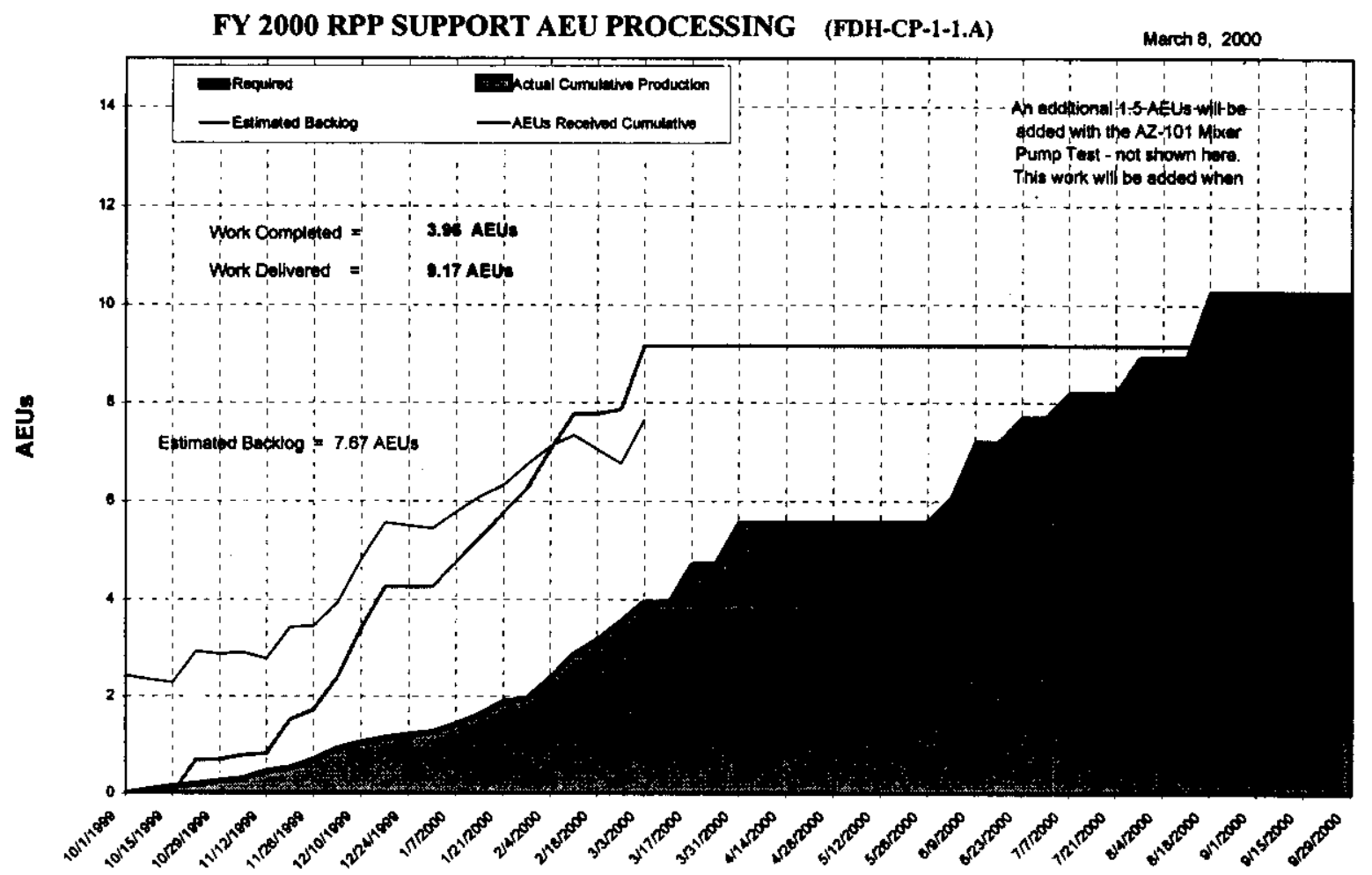

Continue working with RPP on 222-S laboratory production integration. Will meet September commitment of eleven AEUs. Production through March 24, 2000 is 5.3 AEUs.

\section{KEY INTEGRATION ACTIVITIES}

- $\quad$ Support ORP Privatization Readiness-to-Proceed activities.

- Continue to support BNFL efforts to establish required analytical support for glassification operations.

In the longer term, BNFL could utilize unused space at WSCF for cold run test support and process laboratory analytical equipment testing.

The 222-S laboratory, with some refurbishment might become a low cost option to a new large scale laboratory associated with the glassification facility.

- Continue to support RL with the WSCF path-forward study, which evaluates the spectrum of services WSCF provides versus other potential options.

Discussions by the Site Management Board is planned in late April 2000. 

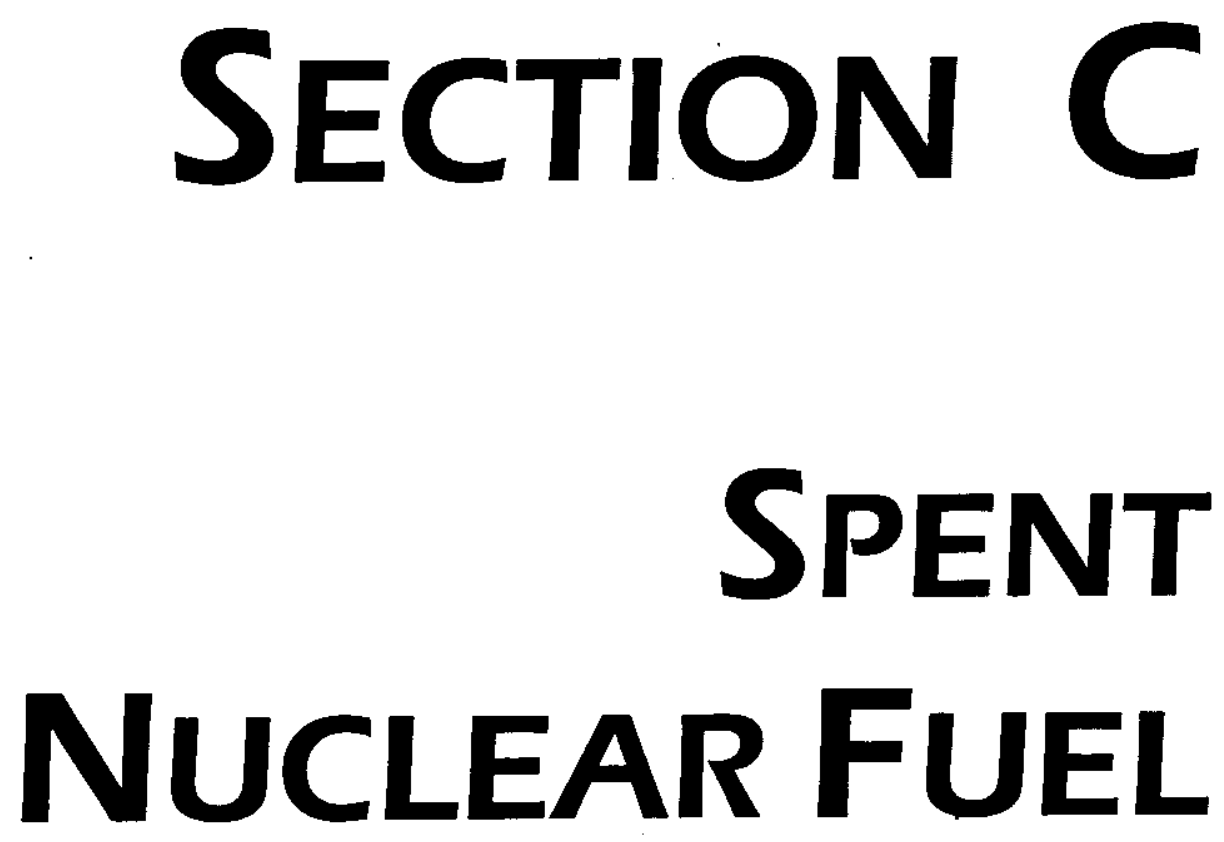

PROJECT MANAGERS

\author{
P. G. Loscoe, RL \\ Phone: (509) 373-7465 \\ R. G. JONES, FH \\ Phone: (509) 376-1413
}




\section{SUMMARY}

The Spent Nuclear Fuel (SNF) mission consists of the Spent Nuclear Fuel Project WBS 1.3.1.1 (Project Baseline Summary [PBS] WM01) and the subsequent Canister Storage Building (CSB) Operations Project WBS 1.3.2.1 (PBS WM02), which doesn't start until FY 2004.

NOTE: Unless otherwise noted, the Safety, Conduct of Operations, and Cost/Schedule data contained herein is as of February 29, 2000. All other information is as of March 27, 2000.

The Canister Storage Building (CSB) is 95 percent complete, compared to 95 percent planned. The Cold Vacuum Drying (CVD) Facility is 89 percent complete compared to 91 percent planned.

Fabrication of production Multi-Canister Overpacks (MCOs) and MCO baskets continued at Joseph Oat, Inc. and the Hanford Site respectively.

Pre-operational Acceptance Testing of systems within Bays 4 and 5 of the Cold Vacuum Drying (CVD) Facility continued. Fabrication of equipment for installation in Bay 3 also continued. The integrated MCO/Process Pre-operational Acceptance Test was initiated.

Welding of all 220 Canister Storage Building (CSB) standard storage tubes necessary for fuel removal from $\mathrm{K}$ Basins was completed.

Fiscal year-to-date milestone performance (EA, DOE-HQ, and RL) shows that two out of two milestones $(100 \%)$ were completed on or ahead of schedule. The Milestone Achievement details, found following cost and schedule variance analysis, provide further information on all milestone types.

\section{ACCOMPLISHMENTS}

- $\quad$ CSB project is 95 percent complete vs. 95 percent planned.

- CVD Facility is 89 percent complete vs. 91 percent planned.

- $\quad$ Completed review of the Canister Storage Building Final Safety Analysis Report (FSAR) with the RL Review Team. Concurrent review provided a shortened review process by approximately 4 weeks. All Spent Nuclear Fuel Project FSARs have been submitted to RL.

- Phase Startup Initiative (PSI) Phase 1 and II testing activities continued. Component tests of the Integrated Water Treatment System (IWTS) were completed successfully. Mechanical barriers in place separating above-water components of IWTS from the underwater components were removed and Basin water was introduced to IWTS. Pre-operational testing of all FRS subsystems is also proceeding. Received RL approval on the Plan of Action for PSI Phase III Readiness Assessment. 
- $\quad$ Startup testing of the Cask Loading System (CLS) components has been initiated. A design/fabrication contract was awarded for the K East Basin IWTS. This award now allows for immediate initiation of design development for the more robust water treatment system required for $\mathrm{K}$ East.

- Initiated the integrated Multi-Canister Overpack (MCO)/Process Pre-operational Acceptance Test (PAT). This integrated test is being conducted after all subsystems' tests have been successfully performed, and when completed, it will demonstrate that the installed process equipment meets its performance criteria for safely drying fuel.

- $\quad$ The Baseline Change Request (BCR) for the sludge acceleration strategy was submitted to $\mathrm{RL}$ for review and approval. This strategy will accelerate completion of sludge removal from the K Basins by one year, while reducing the SNF Project total project cost by approximately $\$ 16$ million.

\section{SAFETY}

Although the SNF Project experienced some safety performance degradations with the start of FY 2000, performance appears to be recovering. October 1999 had 2 Restricted Workday Cases, and 1 Lost Away Workday Case. This was a nearly significant increase (close to but not above the UCL) on the OSHA Recordable Case Rate, and a significant increase (above the UCL) on the Lost / Restricted Workday Case Rate (which is a supplemental graph). The project has achieved almost 750,000 hours safe work hours. The past 9 of 10 months for the DOE Cost Index and Severity Rate have been below average.

The project's safety record is improving in both OSHA recordables and DOE Cost Index. Lost away overall has had only one case in the past year. 

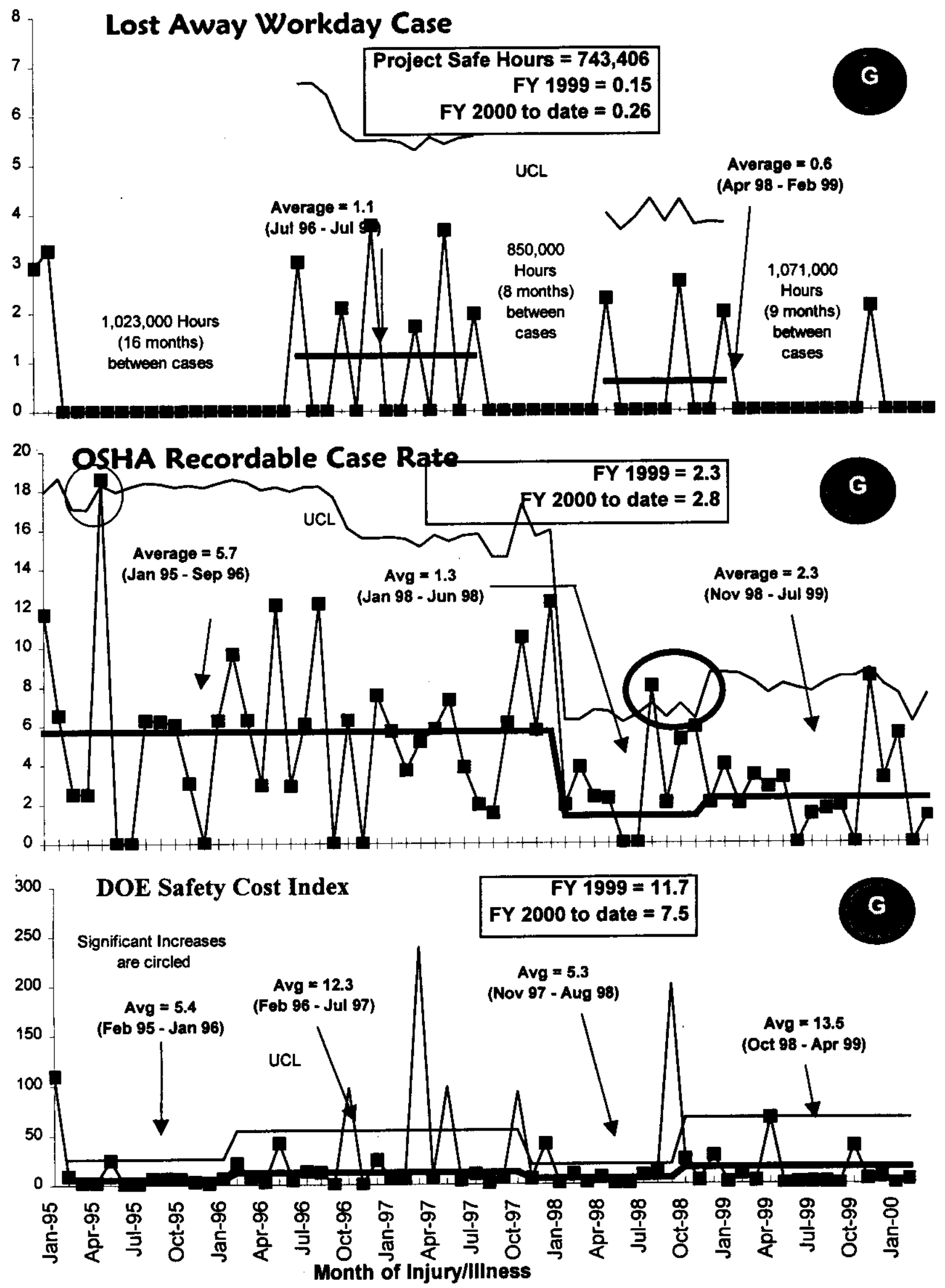


\section{CONDUCT OF OPERATIONS / ISMS STATUS CONDUCT OF OPERATIONS}

\section{Events per 200,000 hours}

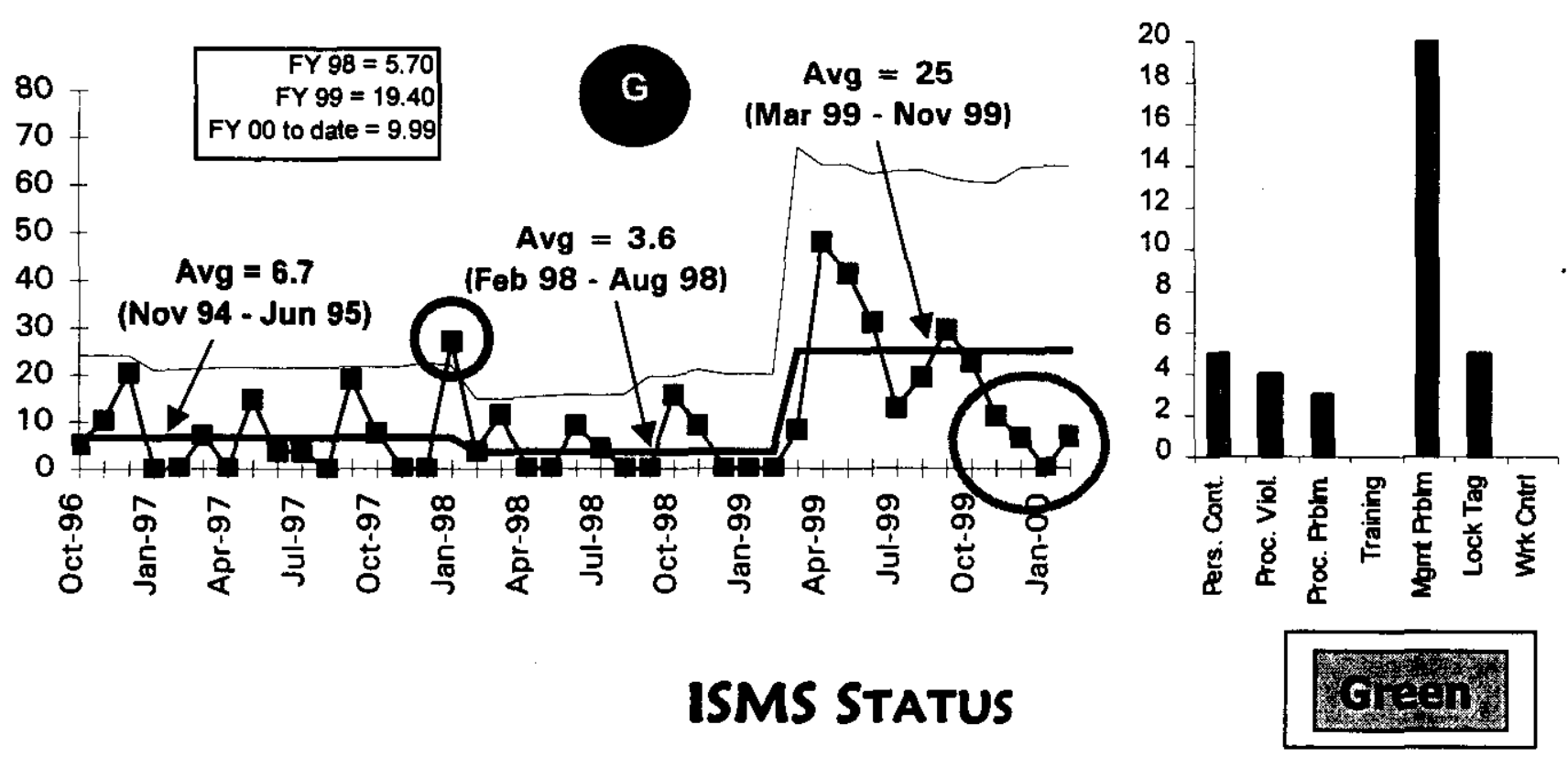

- The ISMS Phase I/II verification for the SNF Project was completed on November 19, 1999

- The Corrective Action Plans for the "Opportunities for Improvement" have been developed and transmitted to RL on January 10, 2000

- The actions required to enable ISMS implementation to be declared March 31, 2000 are now complete. Documentation packages are being prepared for transmittal to the Environmental, Safety \& Health organization.

\section{BREAKTHROUGHS / OPPORTUNITIES FOR IMPROVEMENT}

\section{Breakthroughs}

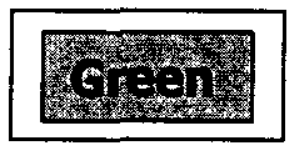

- SNF Project has submitted a Baseline Change Request which implements a strategy to accelerate the completion of sludge removal by one year from August 2005 to August 2004 and reduce total project cost by $\$ 16$ million.

\section{Opportunities for Improvement}

Phased Startup Initiative (PSI) - Results from the PSI are expected to improve the fuel production rates by approximately one month in FY 2001. 


\section{UPCOMING ACTIVITIES}

CVD Facility Testing - Testing at the CVD Facility continues to remain on critical path. Completion of testing is scheduled for the end of May 2000.

Cask Loadout System (CLS) Testing — Complete startup testing by mid-June 2000.

Phased Startup Initiative - Complete PSI Phases $1 \& 2$ by mid-April 2000. Complete Phases 3 \& 4 by mid-August 2000 .

Storage Projects - Deliver first shipment of Multi-Canister Overpacks (MCOs) and baskets by June 1, 2000.

Fuel Removal Activities - Begin DOE Operations Readiness Review by mid-September 2000. Begin K West Basin fuel removal, drying \& storage operations by November 30, 2000.

Sludge Removal Activities - Baseline Change Request submitted to affect a one-year acceleration of the completion of K Basin sludge removal by February 2001.

\section{Cost Performance (\$M):}

\begin{tabular}{|l|c|c|c|}
\hline & BCWP & ACWP & VARIANCE \\
\hline Spent Nuclear Fuel & $\$ 70.9$ & $\$ 82.3$ & $-\$ 11.4$ \\
\hline
\end{tabular}

The unfavorable cost variance of $\$ 11.4$ million (16 percent) is primarily due to engineering, testing, transition and administrative support underestimated for FY 2000; KW punchlist items not in baseline; and Hanford Site assessments higher than baseline.

\section{Schedule Performance (\$M):}

\begin{tabular}{|l|c|c|c|}
\hline & BCWP & BCWS & VARIANCE \\
\hline Spent Nuclear Fuel & $\$ 70.9$ & $\$ 71.3$ & $-\$ 0.4$ \\
\hline
\end{tabular}

The unfavorable schedule variance of \$0.4 million ( 1 percent) is within the threshold. 


\section{FY 2000 Cost/SChedule PerformanCe - All Fund TYPes} Cumulative to Date Status - (\$000)

FYTD

By PBS

BCWS

BCWP

ACWP

sv

$\%$

cV

$\%$

PEM

Spent Nuclear

WM01 Fuel Project

$\begin{array}{lllllllll}\$ 71,297 & \$ 70,917 & \$ 82,314 & \$(380) & -1 \% & \$(11,397) & -16 \% & \$ 195,067\end{array}$

Total

$\begin{array}{llllllll}\$ 71,297 & \$ 70,917 & \$ 82,314 & \$(380) & -1 \% & \$(11,397) & -16 \% & \$ 195,067\end{array}$

\section{Cost/Schedule Performance Indices (FEBRUARY 2000 AND FYTD)}

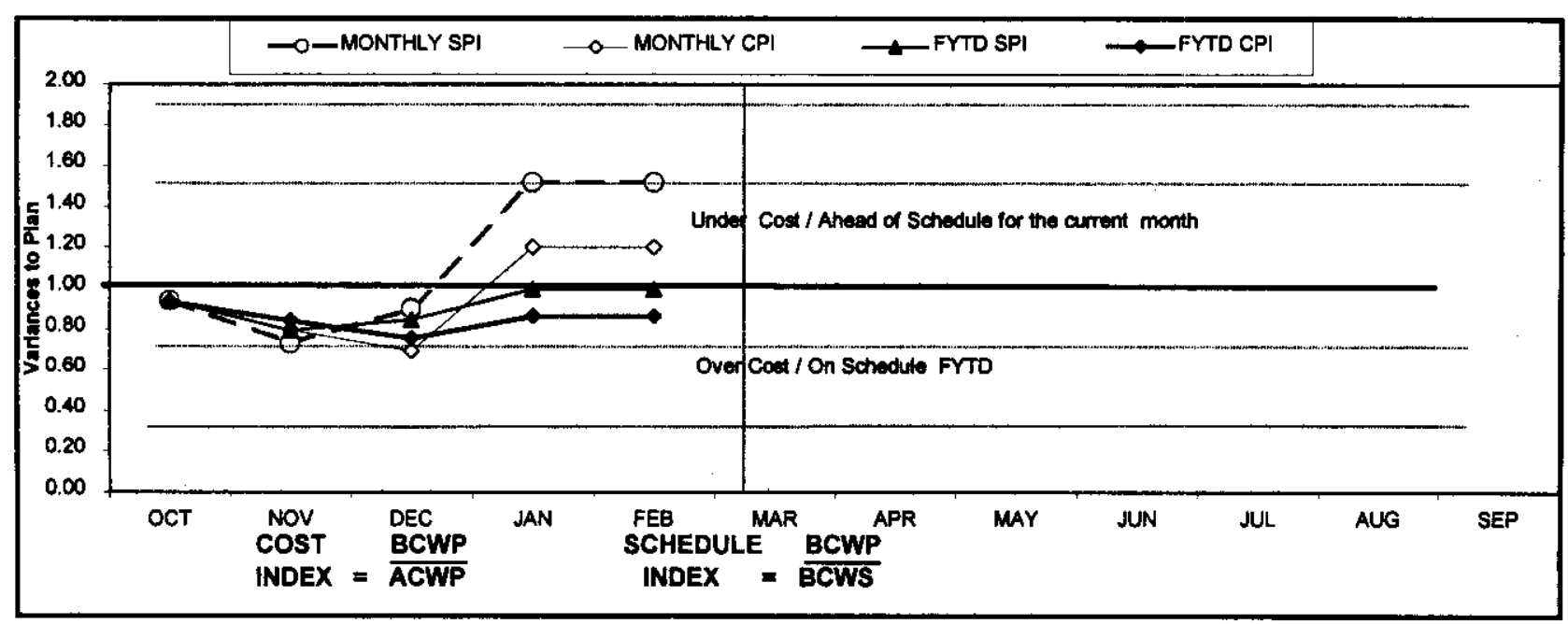

\begin{tabular}{|c|c|c|c|c|c|c|c|c|c|c|c|c|}
\hline Frzous & OCT & NoV & DECC & JAN & FEE & WWR & AfPR & THAY & JUN & JUL & 7NG & SEF \\
\hline MONIFLYSAI & 0.94 & 0.73 & 0.60 & 1.52 & 1.52 & & & & & & & \\
\hline MONIRLYCPI & 0.95 & 0.79 & 0.69 & 1.20 & 1.20 & & & & & & & \\
\hline FYTOSPT & 0.99 & 0.79 & 0.85 & 0.89 & 0.99 & & & & & & & \\
\hline FYIOCAI & 0.95 & 0.84 & 0.75 & 0.86 & 0.86 & & & & & & & \\
\hline MONIRLYBCWS & $\$ \$, 574$ & 319,209 & $\$ 27,762$ & $\$ 15,752$ & $\$ 15,752$ & & & & & & & \\
\hline WONIRLY SCWP & $\$ 8,049$ & 513,508 & $324,8: 0$ & $\$ 23,910$ & $5 \times 23,910$ & & & & & & & \\
\hline MONIRLYACWP & $3 \$ 3,626$ & $3,7,581$ & 756,201 & $\$ 19,900$ & \$19,006 & & & & & & & \\
\hline FYTOECWS & $\$, 574$ & $\$ 27,783$ & 38,464 & $355,5 \times 5$ & $\$ 71,297$ & & & & & & & \\
\hline FYTDECWP & $3+6,049$ & $\$ 22,017$ & $\$ 33,786$ & $\$ 47,007$ & $\$ 70,917$ & & & & & & & \\
\hline FYIDACWP & 38,626 & $\$ 20,207$ & 54,565 & 362,406 & $+26,314$ & & & & & & & \\
\hline
\end{tabular}

\section{COST VARIANCE ANALYSIS: (- \$11.4)}

\section{WBS/PBS}

\subsection{1/WM01}

\section{Title}

Description/Cause: The unfavorable cost variance of $\$ 11.4 \mathrm{M}$ (16.1 percent) is due to engineering, testing, transition and administrative support underestimated for FY $2000(64 \%) ; \mathrm{KW}$ punchlist items not in baseline (14\%); and Hanford Site assessments higher than baseline (10\%). 
Impact: These overruns were anticipated changes foreseen during the contingency analysis and will be allocated through change control. Additional unanticipated cost impacts, i.e., rate increases, Corrective Action Management, Hanford Security, fee allocation are likely to have an adverse impact unless outside funding sources are made available. In addition, Change Requests (CRs) have been developed and reviewed and are on hold pending source availability for $\mathrm{KW}$ punchlist items, engineering, testing and administrative support.

Corrective Action: Pursue other Hanford funding to cover site issues and prioritize SNF work within available SNF budget.

\section{$\underline{\text { WBS/PBS }}$}

\section{SCHEDUle VARIANCE ANALYSIS: (- \$0.4)}

\subsection{1/ WMO1} Title

Description /Cause: The unfavorable schedule variance of $\$ 0.4 \mathrm{M}(0.5$ percent $)$ is within the threshold.

Impact: None.

Corrective Action: None.

\section{ISSUES}

There are no technical, DOE, Regulator or external issues identified at this time.

\section{Baseline Change Requests Currently in Process \\ $(\$ 000)$}

\begin{tabular}{|c|c|c|c|c|c|c|c|c|c|}
\hline $\begin{array}{l}\text { PRONECT } \\
\text { CHANGE } \\
\text { MUMBER }\end{array}$ & DATE OFIGIN. & BCR TILE & $\begin{array}{l}\text { FYoo COST } \\
\text { IMPACT } \\
\$ 000\end{array}$ & $\mathbf{S C H}$ & TECH & $\begin{array}{c}\text { DATE TO } \\
\text { FDH } \\
\text { CCB }\end{array}$ & $\begin{array}{c}\text { CCB } \\
\text { APRVD }\end{array}$ & $\begin{array}{c}\text { RL } \\
\text { APRVD }\end{array}$ & $\begin{array}{l}\text { CURRENT } \\
\text { STATUS }\end{array}$ \\
\hline SNFF-20000018 & $11 / 29 / 99$ & $\begin{array}{l}\text { Change Path Forward for K-Basin } \\
\text { Sludge from interim Storage in } \\
\text { TWRS Doublo-Shell Tanks to T } \\
\text { Plant }\end{array}$ & & $\mathbf{T}$ & Y & $7 / 5100$ & $7 / 5 / 00$ & $2 / 77100$ & $\begin{array}{l}\text { RoceivedRL CO } \\
\text { signeture, } \\
2 / 17 / 2000\end{array}$ \\
\hline SNF-2000-009 & $1 / 31 / 00$ & Sludgo Acceleration Strategy & & $\mathbf{Y}$ & $\mathbf{Y}$ & $2 / 24 / 00$ & $2 / 25 / 100$ & & $\begin{array}{l}\text { Transmitted to RL } \\
2 / 28 / 00 \text {. }\end{array}$ \\
\hline SNF-2000-010 & $1 / 31 / 00$ & $\begin{array}{l}\text { SNF Project FY2000 MYWP } \\
\text { Reised Rate impects }\end{array}$ & & N & N & & & & In preperation. \\
\hline SNF-2000-012 & $2 / 16 / 00$ & $\begin{array}{l}\text { SHe Wide SNF Reschedule Dus to } \\
\text { Htanford Site Priorities }\end{array}$ & $<\$ 1,300\rangle$ & $\mathbf{Y}$ & N & & & & In properation. \\
\hline SNF-2000-013 & $3 / 6 / 00$ & $\begin{array}{l}\text { Delayed Scope for TGA Semple } \\
\text { Disposal }\end{array}$ & & Y & $\mathbf{Y}$ & & & & In preperation. \\
\hline SNF-2000-014 & $3 / 20100$ & FY2000 Budget Authority Increase & $\$ 1,300$ & $\mathbf{N}$ & $\mathbf{N}$ & & & & In preperation. \\
\hline \multicolumn{10}{|c|}{ ADVANCE WORK AUTHOREATIONS } \\
\hline None & & & - & & & & & & \\
\hline
\end{tabular}




\section{SPENT NUCLEAR FUELS - WBS 1.3 \\ MILESTONE ACHIEVEMENT}

\begin{tabular}{|c|c|c|c|c|c|c|c|c|}
\hline \multirow[b]{2}{*}{ MILESTONE TYPE } & \multicolumn{4}{|c|}{ FISCAL YEAR-TO-DATE } & \multicolumn{3}{|c|}{ REMAINING SCHEDULED } & \multirow[b]{2}{*}{$\begin{array}{c}\text { TOTAL } \\
\text { FY } \\
2000\end{array}$} \\
\hline & $\begin{array}{c}\text { Completed } \\
\text { Early }\end{array}$ & $\begin{array}{c}\text { Completed } \\
\text { On } \\
\text { Schedule }\end{array}$ & $\begin{array}{c}\text { Completed } \\
\text { Late }\end{array}$ & Overdue & $\begin{array}{c}\text { Forecast } \\
\text { Early }\end{array}$ & $\begin{array}{c}\text { Forecast } \\
\text { On } \\
\text { Schedule }\end{array}$ & $\begin{array}{c}\text { Forecast } \\
\text { Late }\end{array}$ & \\
\hline Entorceable Agreement & 1 & 1 & 요 & 0 & of & 0 & of & 2 \\
\hline DOE-HQ & 0 & 0 & of & 0 & of & of & 0 & 0 \\
\hline RL & 0 & 0 & 0 & 0 & 여 & 4 & 0 & 4 \\
\hline Total Project & 1 & 1 & 0 & 0 & 0 & 4 & 0 & 6 \\
\hline
\end{tabular}

Thi-Party Agreement / EA Milestones

M-34-14A (S06-97-009), "Complete K West Basin Cask Facility Modifications", due 2/29/00 - Completed on schedule.

M-34-04 (S01-99-124), "Submit Remedial Design Report/Remedial Action Work Plan for the KBasins", due $3 / 31 / 00$ - Completed over 1 month early $(2 / 10 / 00)$.

M-34-15B-T01, "Complete remaining bay(s) of the Cold Vacuum Drying Facility construction and installation", due 6/30/00 - Proposed BCR SNF-2000-009 will delete this milestone.

M-34-13B-T01, "Complete construction and installation of K East Basin Spent Nuclear Fuel Retrieval System", due 11/30/00 - Proposed BCR SNF-2000-009 will defer this milestone to 3/31/02.

M-34-16 (S00-01-900), "Initiate removal of K West Basin Spent Nuclear Fuel", due 11/30/00 - On schedule.

M-34-06-T01, "Initiate K West Basin Spent Nuclear Fuel Canister Cleaning Operations", due 12/31/00 - On schedule.

Nothing to report.

\section{MILESTONE EXCEPTION REPORT}

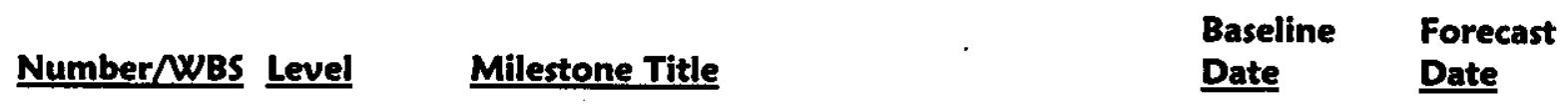

\section{Overdue - 0}

ForecAST LATE - 0 


\section{Performance Objectives}

Readiness for Fuel Movement (RC-1-1.a-I) - Contractor completion of construction and operational testing, Management Self-Assessment, and Independent ORR by $9 / 14 / 00$ to begin moving fuel by $11 / 30 / 00$. Start of fuel movement is currently on track for $11 / 30 / 00$.

Phased Startup Initiative (PSI) (RC-1-1.a-II) - Complete PSI Phases $1 \& 2$ by April 15, 2000. This includes successful Cold Testing of IWTS \& FRS. This activity is behind schedule.

K East Fuel Retrieval System (RC-1-1.b) - Complete facility modification necessary to allow FRS installation by September 30,2000, as defined in the MYWP. Baseline Change Request in process to remove this activity with implementation of new strategy.

Accelerate Fuel Movement (RC-1SS-1) - Accelerate start of fuel movement by two months. Assumes no problems during first fuel movement and no ORR or MSA discrepancies.

Phased Startup Initiative (PSI) (RC-1SS-2) - Complete Phases 3 \& 4 by August 15, 2000. This includes completion of FRS/IWTS system testing using SNF (real fuel) and completion of CCD2. This activity is on schedule.

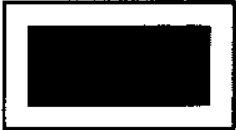

\section{KEY INTEGRATION ACTIVITIES}

- $\quad$ Spent nuclear fuel (SNF) final disposition interface activities, including OCRWM QA Program implementation, ongoing with National SNF Program.

- $\mathrm{K}$ Basins sludge removal and Shipping port (PA) Pressurized Water Reactor Core 2 SNF removal implementation activities ongoing with Waste Management; Baseline Change Requests are in preparation by the SNF Project and Waste Management to support integrated activity for accelerated sludge removal strategy. Funding authorized for initial T-Plant readiness activities.

- $\quad 324$ Building (B Cell) SNF removal acceptance criteria and conceptual design reviews ongoing with River Corridor Project.

- Neutron Radiography Facility, Training, Research and Isotope Production, General Atomics (TRIGA), and FFTF SNF relocation planning ongoing with FFTF Project.

- Input provided to BHI on recovery actions required if SNF is discovered during upcoming reactor basins deactivation.

- Completed assessment and draft documentation for the Canister Storage Building's readiness to support the receipt of Immobilized High Level Waste (IHLW) from ORP. This is in direct support of DOEs Readiness to Proceed determination of the Hanford Vitrification Plan. 

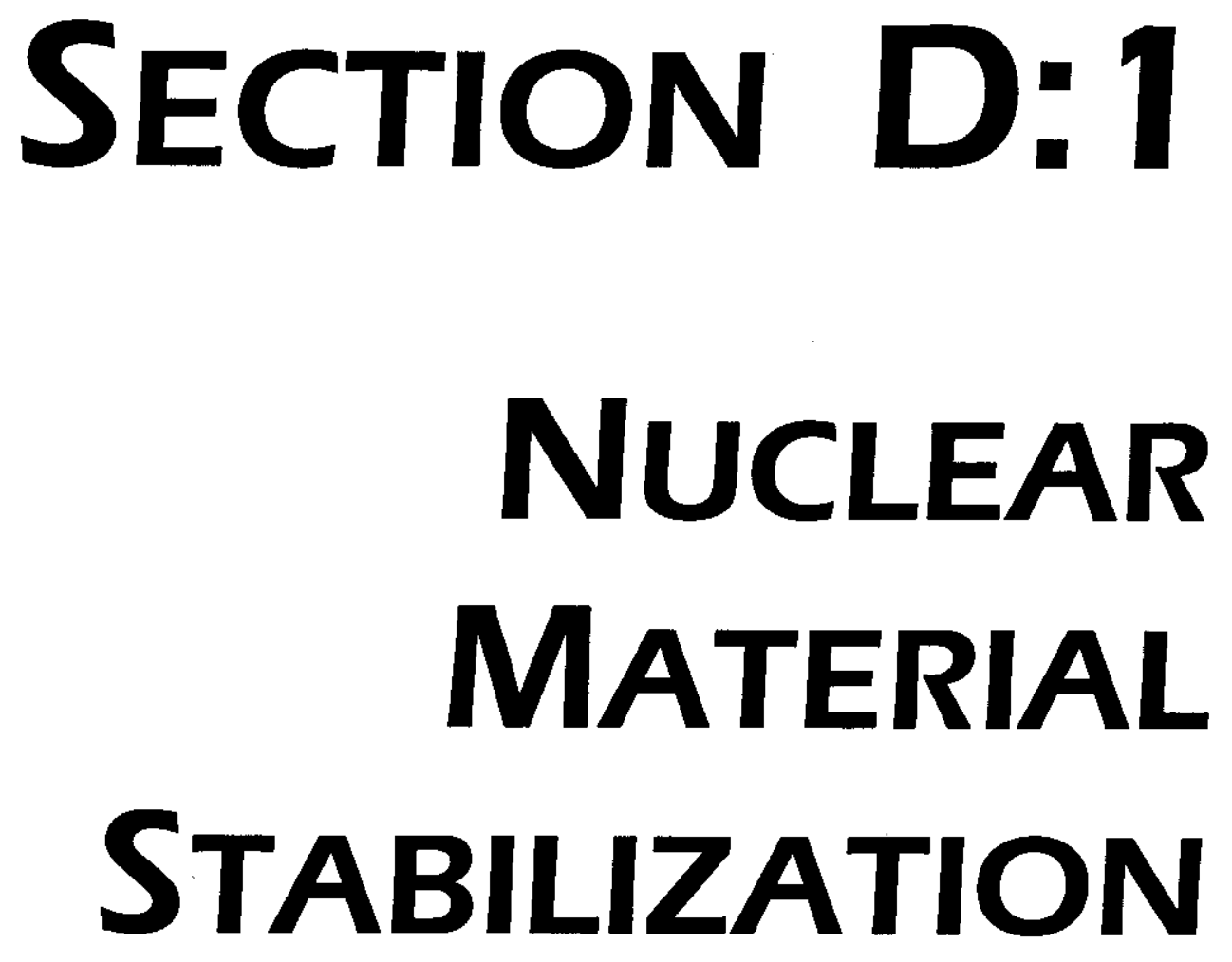

PROJECT MANAGERS

P. M. Knollmeyer, RL

Phone: (509) 376-7435

G. W. Jackson, WSMS

Phone: (509) 373-6622 


\section{SUMMARY}

The Nuclear Material Stabilization mission consists of the Plutonium Finishing Plant (PFP), WBS 1.4.5, PBS TP05.

NOTE: Unless otherwise noted, the Safety, Conduct of Operations, and Cost/Schedule data contained herein is as of February 29, 2000. All other information is as of March 21, 2000.

As of March 17, 2000 a total of 201 cans of Plutonium oxides and sludges have been stabilized through thermal stabilization (28 items since last report). A total of 13 liters of Plutonium nitrate solution have been stabilized in the prototype vertical denitration calciner (i.e., no change since December 1999 due to focus on $\mathrm{Mg}(\mathrm{OH})_{2}$ Precipitation Process installation activities).

Progress is nearly complete on the installation of three additional muffle furnaces for thermal stabilization of oxides and on installation of one (1) of three (3) $\mathrm{Mg}(\mathrm{OH})_{2}$ process system glove boxes for stabilization of solutions.

Fiscal-year-to-date milestone performance (EA, DOE-HQ, and RL) shows that one of two milestones ( 50 percent) was completed on or ahead of schedule, no milestones were completed late, and one (50 percent) is overdue. Milestone (TRP-00-500) is late due to a proposed change in process implementation. A letter was sent to $R L$ indicating the milestone would not be met. Further details can be found in the milestone exception report following the cost and schedule variance analysis.

\section{ACCOMPLISHMENTS}

- Declared readiness and initiated phased startup of three additional muffle furnaces.

- Continued progress to support startup of Pu Solution Stabilization:

Accelerated delivery of remaining process glove boxes and equipment.

Completed facility tie-in design.

Issued Operational Readiness Review Plan of Action (POA) for internal review.

- $\quad$ Approved National Environmental Policy Act of 1969 (NEPA) Environmental Impact Statement (EIS) Supplement Analysis in support of Project W-460, Plutonium Stabilization and Packaging System.

- $\quad$ DOE-RL approved a request to devalue Buildings 216-Z-9-A\&B enabling fire detection systems to be deactivated.

- $\quad$ Completed sprinkler replacement project.

- Identified potential Pu metal safety vulnerability and initiated rapid corrective actions.

- Plutonium Oxide Stabilization - A total of 201 cans of oxides/sludges have been stabilized (28 items since last report). 


\section{SAFETY}

Safety performance has continued excellent in February with no OSHA Recordable or Lost Workday Case injuries.

Case reclassifications and additional days on open cases have caused readjustments of past data. There continues to be a growth in lost/restricted days for February 2000.

The past eight months were below average on the Cost Index. OSHA recordable case rate has significantly improved in comparison to the adverse trend of Spring 1999. An initial baseline rate of 2.5 has been calculated, which is equal to the PHMC overall rate. 

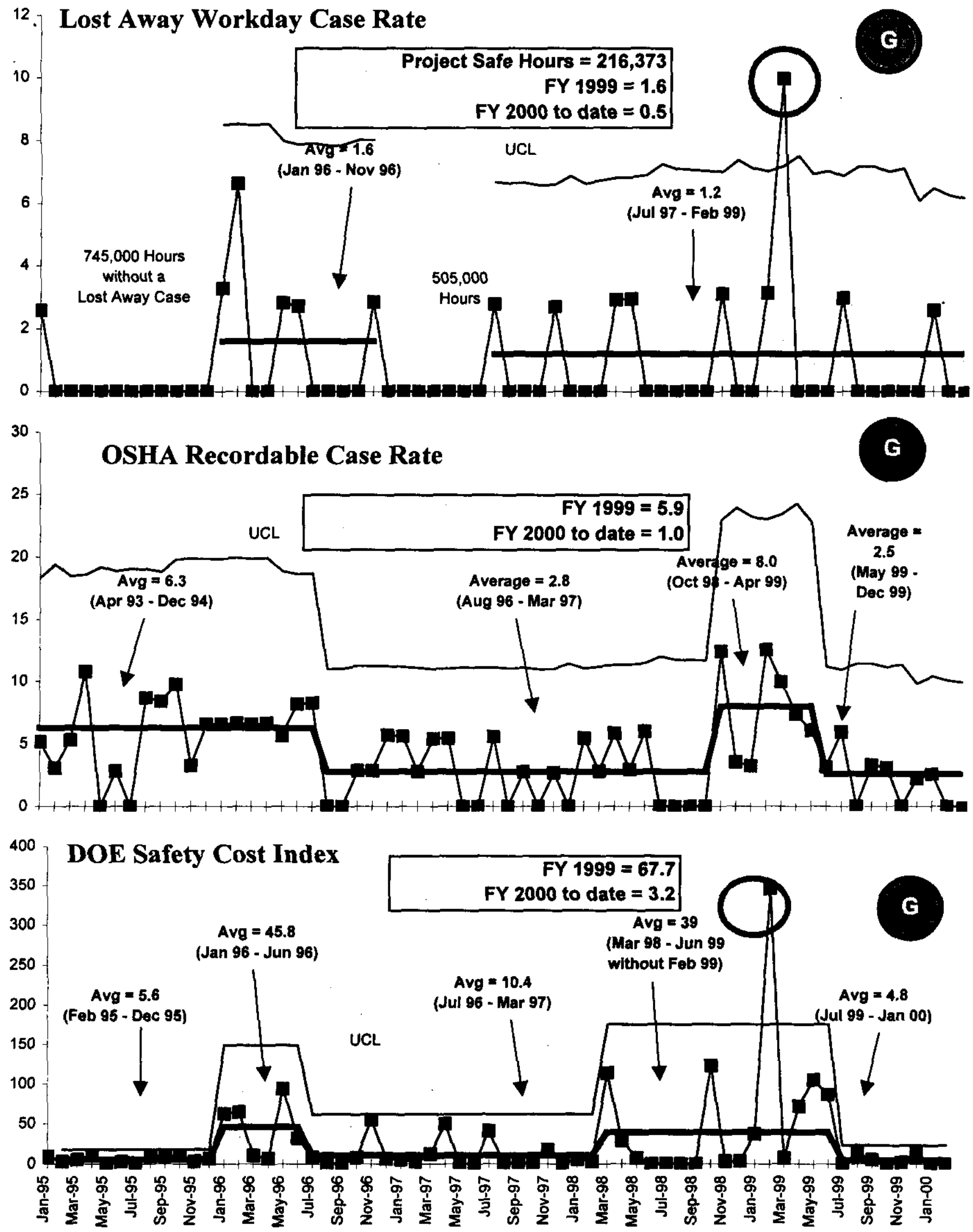


\section{CONDUCT OF OPERATIONS / ISMS STATUS CONDUCT OF OPERATIONS Events per 200,000 Hours}
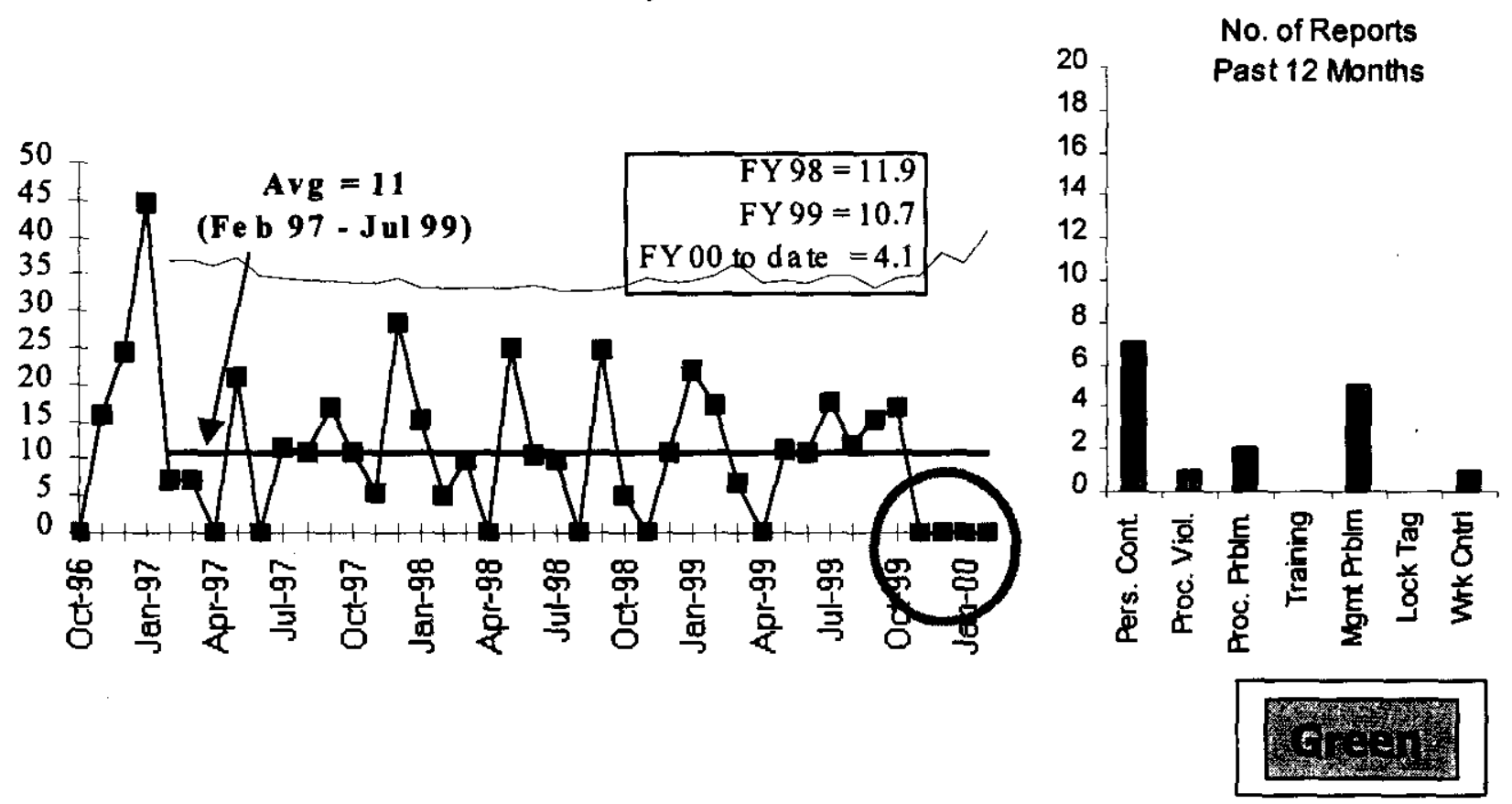

\section{ISMS STATUS}

- $\quad$ Phase I verification assessment of Integrated Safety Management System ISMS was completed:

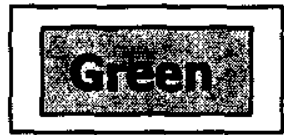

Corrective Actions have been defined and scheduled.

Current draft schedule indicates corrective actions complete by April 15.

- $\quad$ Phase II Verification will be completed in conjunction with all Fluor projects during the $3^{\text {rd }}$ quarter of the fiscal year.

\section{BREAKTHROUGHS / OPPORTUNITIES FOR IMPROVEMENT}

\section{BREAKTHROUGHS}

- Implementation of a WIPP "validated" plutonium measuring nondestructive assay (NDA) system in FY 2000 is being worked. If successful, implementation of this WIPP "validated" Pu NDA measurement for residue materials prior to cementation will significantly reduce shipment costs to WIPP (i.e., results in significantly fewer drums by as much as 1000 , which will reduce overall costs by approximately $\$ 2.4 \mathrm{M}$ (i.e., $\$ 2.4 \mathrm{~K}$ per drum).

\section{OPPORTUNITIES FOR IMPROVEMENT}

- Efforts to accelerate all phases of the clearance process continue with the assistance of DOE-RL. NMS is actively engaged in adding Yellow appropriate staff to catch back corresponding schedule delays. 
Status: Selected staffs have been allowed to report for training classes prior to receiving clearances. [This item will no longer be reported.]

- There is a need to identify and consolidate various cost saving initiatives resulting from increased operating efficiencies. Conduct a summit meeting of all parties to maximize efforts and direct savings to accelerate stabilization activities.

Status: Opportunities for savings are continuing to be investigated. [This item will no longer be reported.]

- Initiated accelerated furnace cool-down work plan and early tests indicate a significant savings in time required for cool-down. Opening the furnace doors at 400 degrees increased the glovebox temperature only two degrees temporarily and saved over three hours in the cooling time. Expect to be able to continue to at least 600 degrees without negative effects.

- Modification of Personnel Security Assurance Program (PSAP) two-man rule requirements, which would provide a potential reduction of resources for facility surveillance and maintenance activities.

- $\quad$ Modified PFP airborne radioactivity area (ARA) posting practice allowing limited area ARA posting to support duct level decontamination without posting the entire processing area as ARA. This not only provides a current cost savings by reducing resources needed for duct level decontamination work, it is also being reviewed for implementation in other areas.

\section{UPCOMING ACTIVITIES}

- $\quad$ Begin Pu solution stabilization via $\mathrm{Mg}(\mathrm{OH})_{2}$ in the $4^{\text {th }}$ quarter of FY 2000:

Deliver glove boxes and equipment for installation by April 11, 2000.

Complete ORR and training activities.

- Startup Cementation operations in the $4^{\text {th }}$ quarter of FY 2000 (i.e., July 2000).

- Commence full unrestricted operation of five new muffle furnaces in March 2000.

- Complete Pipe-and-Go evaluation and long lead regulatory permits.

- Complete Project W-460 Facility Design by April 2000.

- Complete installation and startup of the BTS by October 2000.

- Begin metal stabilization processing in November 2000.

\section{Cost Performance $(+\$ 2.9 M):$}

\begin{tabular}{|l|c|c|c|}
\hline & BCWP & ACWP & VARIANCE \\
\hline Nuclear Material Stabilization & $\$ 43.5$ & $\$ 40.5$ & $\$ 3.0$ \\
\hline
\end{tabular}

The $\$ 3.0$ million ( 7 percent) favorable cost variance is due to a shortage of staff, a lag in costs for contracts [e.g., including the Energy Services contract for steam, $\mathrm{Mg}(\mathrm{OH})_{2}$ glove box procurements, etc], and accelerated completion of baseline activities for oxide stabilization. 


\section{SChedule Performance ( $\$ 8.8 \mathrm{M})$ :}

\begin{tabular}{|l|c|c|c|}
\hline & BCWP & BCWS & VARIANCE \\
\hline Facility Stabilization & $\$ 43.5$ & $\$ 52.3$ & $-\$ 8.8$ \\
\hline
\end{tabular}

The $\$ 8.8$ million (17 percent) unfavorable schedule variance is due primarily to the behind status on Project W-460 vault modification construction awaiting final determination from EIS Supplement Analysis and equipment procurements, such as glove boxes, NDA lab equipment and outer can welder activities. Also, Project W-460 trailer installation activities have not started as scheduled but instead will be removed as part of the DOE-HQ directed 5\% funding reduction in FY 2000. Also contributing to the unfavorable schedule variance is a hold on shipment of sand, slag and crucible to SRS due to the unavailability of shipping containers. There is delay in the installation of the $\mathrm{Mg}(\mathrm{OH})_{2}$ system. Residue and polycube stabilization planned activities have changed and progress can't be claimed until approval of pending BCRs (approved in March 2000; will be implemented in March 2000). 


\section{FY 2000 Cost/Schedule Performance - All Fund Types Cumulative to Date Status - $(\$ 000)$}

FYTD

By PBS

BCWS BCWP ACWP

SV

$\%$

CV $\%$

PEM

WBS

1.4.5 PFP

TP05 Deactivation

$\$ 52,307$

$\$ 43,470$

$\$ 40,516$

$\$(8,837)$

$-17 \% \$ 2,954$

$7 \% \$ 126,218$

Total

$\$ 52,307$

$\$ 43,470$

$\$ 40,516$

$\$(8,837)-17 \% \quad \$ 2,954$

$7 \% \$ 126,218$

RL-Directed costs (steam) are included in the PTS BCWS.

\section{Cost/Schedule Performance Indices (FEBRUARY 2000 AND FYTD)}
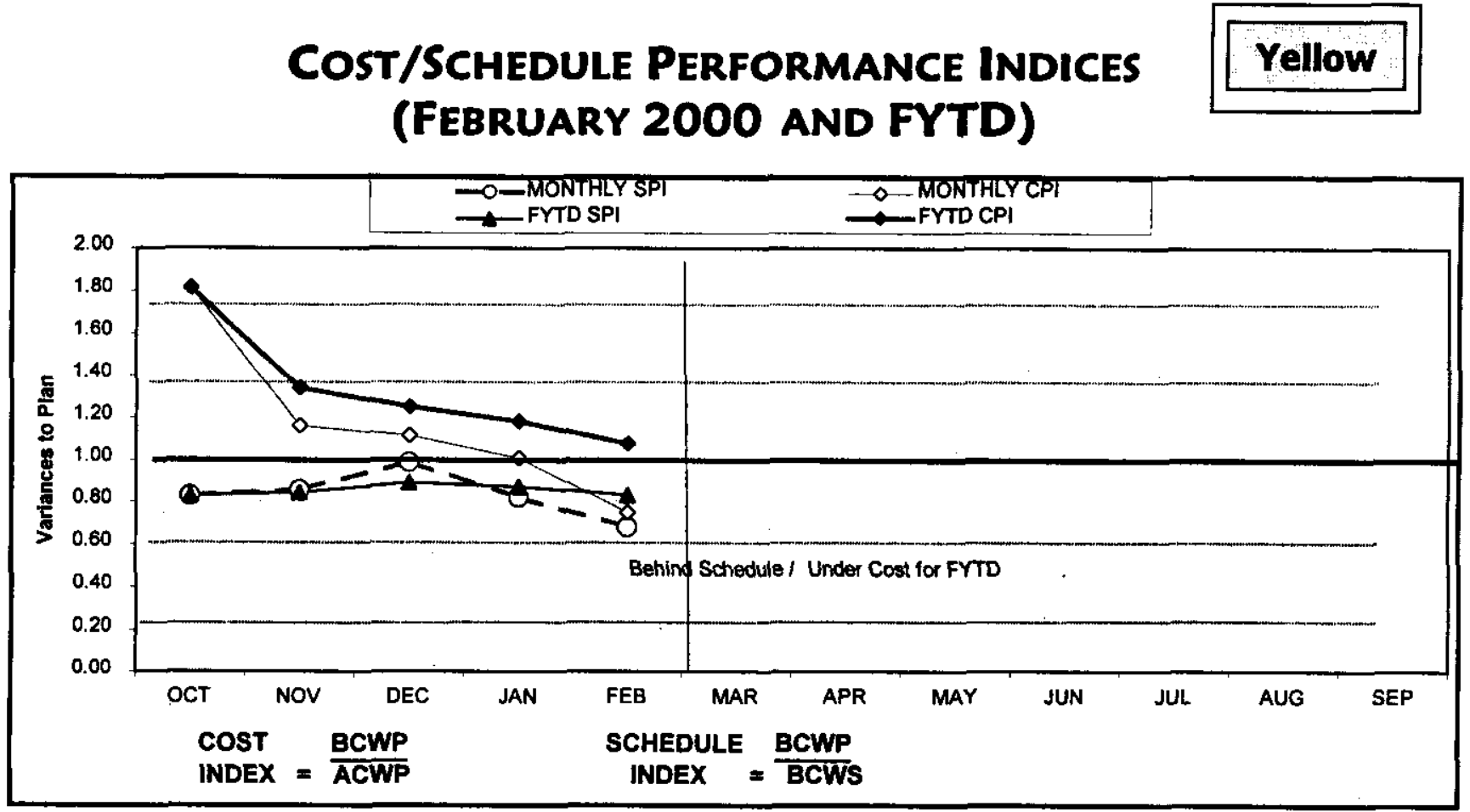

\begin{tabular}{|c|c|c|c|c|c|c|c|c|c|c|c|c|}
\hline FY2000 & OCT & NOV & DEC & JAN & FEB & TWAR & APR & TMAY & JUN & JUL & AUG & SEP \\
\hline MONTHLY SP & 0.83 & 0.85 & 0.98 & 0.82 & 0.68 & & & & & & & \\
\hline MONIHLY CPI & 7.81 & 1.18 & 1.11 & 7.01 & 0.75 & & & & & & & \\
\hline FYTOSPT & 0.83 & 0.84 & 0.89 & 0.87 & 0.803 & & & & & & & \\
\hline FYTOCPI & 1.81 & 1.34 & 7.25 & 7.18 & 1.07 & & & & & & & \\
\hline MONTRLY BCWS & $\$ 7,913$ & $\$ 12,725$ & 39,899 & 310,540 & $\$ 17,130$ & & & & & & & \\
\hline MONTHLY BCWP & $\$ 6,543$ & $350,87 / 3$ & $\$ 9,849$ & 38,638 & $\$ 7,567$ & & & & & & & \\
\hline MONTHLYACWP & $\$ 3,613$ & $\$ 9,366$ & $\$ 8,845$ & 38,587 & 510,085 & & & & & & & \\
\hline FYTDBCWS & $\$ 7,913$ & $\$ 20,638$ & $\$ 30,637$ & $\$ 41,177$ & $\$ 52,307$ & & & & & & & \\
\hline FYTOBCWP & $\$ 6,543$ & $\$ 17,416$ & 327,265 & $\$ 35,903$ & $\$ 43,470$ & & & & & & & \\
\hline FYTDACWP & $\$ 3,613$ & $\$ 12,999$ & $\$ 21,844$ & $\$ 30,437$ & $\$ 40.518$ & & & & & & & \\
\hline
\end{tabular}




\section{COST VARIANCE ANALYSIS: (+\$2.9M)}

\section{$\underline{\text { WBS/PBS }} \quad$ Title}

\subsection{0/TP05 Maintain Safe and Secure SNM (+\$0.9M)}

Description and Cause: Underrun due to lag in subcontractor invoices and accruals.

Impact: No impact.

Corrective Action: None required.

\subsection{3/TP05 Stabilization of Nuclear Materials at PFP $(+\$ 2.4 \mathrm{M})$}

Description and Cause: The favorable cost variance is due to accelerated completion of the baseline activities for oxide stabilization with fewer resources and lag in subcontractor and material invoices and accruals. The favorable cost variance for oxide stabilization should continue as additional oxide stabilization occurs within the original baseline budget for FY 2000. This favorable variance is partially offset by unfavorable variances in residue and polycube stabilization. The residue and polycube stabilization budget does not reflect changes in the work being performed under advance work authorization.

Impact: None

Corrective Action: Approve and implement baseline change requests to reflect revised path forward for residue and polycube stabilization activities (BCRs now approved in March 2000).

\subsection{4/TP05 Disposition of Nuclear Materials (+\$1.8M)}

Description and Cause: Positive cost variance is the result hiring delays and lag in subcontractor and material invoices and accruals.

Impact: Potential delay in BTS startup.

Corrective Action: Maintain aggressive hiring, training, and clearance program for Nuclear Operators and other support.

\subsection{5/TP05 Transition PFP (-\$0.5M)}

Description and Cause: The unfavorable cost variance is the result of increased costs for lab analysis of tank samples as well as carryover work scope not yet reflected in the baseline.

Impact: If work scope is stopped due to budget issues, the Tri-Party Agreement milestone due May 31,2000 would not be met. Continuing work scope will result in cost over run for this activity, savings from elsewhere within NMSP will be required to offset the overrun.

Corrective Action: Approve and implement baseline change request to reflect FY 1999 carryover work scope. If PCBs are found to exceed allowable limits, a separate change request may be required to incorporate the additional special waste handling requirements into the baseline. Identify cost savings from elsewhere within the NMSP to offset this over run.

\subsection{2/TP05 PFP Fee Allocation (-\$1.8M)}

Description and Cause: Unfavorable cost variance due to point adjustment $(-\$ 1,769 \mathrm{~K})$ in October to adjust for delay in staff hiring ramp-up at the beginning of FY 2000. Also an increase in the fee accrual from a rate $90 \%$ to $100 \%$.

Impact: No impact.

Corrective Action: None required. 


\section{SCHedule VARIANCe ANAlysis: $(-\$ 8.8)$}

\section{WBS/PBS}

\subsection{4/TP05}

Description and $\mathrm{C}$ construction of Line Item Project W-460, Plutonium Stabilization and Packaging System. A portion of this schedule variance is the result of work scope that is being deleted due to the FY 2000 funding reduction, a baseline change request is in process. Also contributing to the unfavorable schedule variance is the hold on shipment of sand, slag and crucible to SRS. Due to the unavailability of shipping containers, SS\&C will be processed at PFP rather than shipped to SRS; this change has been documented via change control.

Impact: Potential delay in BTS start up.

Corrective Action: Approve and implement baseline change requests currently in process.

\subsection{3/TP05}

Stabilize SNM (-\$1.6M)

Description and Cause: The unfavorable schedule variance is due to changes in the planned activities for residue and polycube stabilization. The revised path forward for these two activities is being worked via an advance work authorization but performance will not be recognized until approval of the pending baseline change requests (approved in March 2000). Also contributing to this schedule variance is the delay for installation of the $\mathrm{Mg}(\mathrm{OH})_{2}$ system.

Impact: The installation of the $\mathrm{Mg}(\mathrm{OH})_{2}$ system will be completed late; expect to complete the FY $2000 \mathrm{Pu}$ Solution stabilization baseline scope by year end.

Corrective Action: Approve and implement baseline change requests currently in process. Continue to pursue options to compress $\mathrm{Mg}(\mathrm{OH})_{2}$ installation and startup schedule.

\subsection{5/TP05 Transition PFP (-\$0.1M)}

Description and Cause: Delays in setup and start of extruding samples in 222-S Laboratory Sample Analysis. Also, initial plan was to use a hood for analysis, but a hot cell had to be used.

Impact: No Impact expected.

Corrective Action: Expect to recover schedule by the end of March.

\section{ISSUES}

DOE Standard 3013-99 requires that "oxides shall be stabilized by heating the material in an oxidizing atmosphere to a Material Temperature of at least $950^{\circ} \mathrm{C}$... for not less than 2 hours."

Impact(s): If unable to qualify stabilization process without any modification, a significant process modification may be required.

Corrective Action: A test plan has been drafted to evaluate our process and potential options. We are working with Rocky Flats to come to a joint solution. 
Lack of certified shipping containers in the DOE Complex to meet PFP schedules.

Impact(s): Prohibits shipment of nuclear materials that cannot go to either WIPP or DOT$6 \mathrm{M}$ containers (i.e., Pu standards for re-certification, shipment of reactive materials for processing elsewhere, etc,)

Corrective Action: Work with the DOE Complex to certify containers to meet PFP shipping needs (i.e., 9975 container to be re-certified in June 2000, etc.).

Jointly resolve issues associated with precipitation process. Concentration, Density, Filtrate Handling (permitting of $241-\mathrm{Z}$ to handle heavy metals), discard directly to tank farms.

Impact(s): Significantly impacts the number of containers to be stored under final disposition (approximately 1000 additional containers).

Corrective Action: Establish a team to develop a path forward to resolve these issues.

Implementation of supercritical fluid extraction technology for moisture measurements will require installation of a new glovebox in room 235-B.

Impact(s): This installation will require several hundred thousand dollars more than budgeted for procurement and installation and result in several weeks of processing impact during the installation.

Corrective Action: Establish a cost and schedule estimate for the installation of this equipment and process a BCR to modify schedule.

Equipment for processing Pu inside the gloveboxes needs to be defined and approved by Operations before glovebox size can be finalized.

Impact(s): Gloveboxes cannot be ordered until size is finalized.

Corrective Action: Use mockup and daily meetings with Operations to finalize the internal arrangement of the gloveboxes to the point where a size can be determined and the gloveboxes ordered.

Seismic concerns with room 638 cage, $2736-Z B$ facility.

Impact(s): Completing recovery plan to address these issues, resulting in higher exposure than normal to vault operators.

Corrective Action: Install new seismically qualified racks in room 638 cage. 


\section{Baseline Change Requests Currently in Process}

\section{$(\$ 000)$}

\begin{tabular}{|c|c|c|c|c|c|c|c|c|}
\hline $\begin{array}{l}\text { PROJECT } \\
\text { CHANGE } \\
\text { NUMBER }\end{array}$ & $\begin{array}{c}\text { DATE } \\
\text { ORIGINAL }\end{array}$ & BCR TITLE & $\begin{array}{c}\text { FYO0 } \\
\text { COST } \\
\text { IMPACT }\end{array}$ & $\mathrm{SCH}$ & TECH & $\begin{array}{l}\text { DATE TO } \\
\text { FHI CCB }\end{array}$ & $\begin{array}{c}\text { CCB } \\
\text { APR'VD }\end{array}$ & RL APR'VD \\
\hline FSP-2000-001 & $13-0 \mathrm{ct}-99$ & $\begin{array}{l}\text { Delete TRP-99419, Complete Install. of } \\
\text { Production Scale Vertical Calciner }\end{array}$ & $\$ 0$ & & & & & \\
\hline FSP-2000-004 & 23-Nov-99 & $\begin{array}{l}\text { PFP Test Polycube Stabilization via Muffle } \\
\text { Furnace }\end{array}$ & $\$ 0$ & $\bar{X}$ & $\mathbf{X}$ & $17-\mathrm{Feb}-00$ & 17-Feb-00 & \\
\hline FSP-2000-005 & $30-\mathrm{Nov}-99$ & $\begin{array}{l}\text { Implement PFP Int Proj Mgmt Plan } \\
\text { Addendum I }\end{array}$ & $\$ 659$ & $\bar{X}$ & $\bar{X}$ & & & \\
\hline FSP-2000011 & 27-Dec-99 & $\begin{array}{l}\text { Adjusted PFP Cementation Processing to } \\
\text { include Sand, Slag and Crucible }\end{array}$ & $\$ 0$ & $\mathrm{X}$ & $\mathbf{X}$ & $14-\mathrm{Jan}-00$ & $18-\operatorname{Ian}-\infty 0$ & 17 -Feb-00 \\
\hline FSP-2000-025 & 10-Mgr-00 & PFP Replacement Transformer & $\$ 992$ & $\overline{\mathbf{X}}$ & & $27-\mathrm{Mar}-00$ & 27-Mar-00 & Not Reg'd \\
\hline FSP-2000-029 & 26- $\operatorname{Jan}-00$ & PFP FY2000 Funds Recuction & $(\$ 6,885)$ & $\bar{X}$ & & 9.Mar- 00 & 23-Mar-00 & \\
\hline & & & & & & & & \\
\hline & & & & & & & & \\
\hline
\end{tabular}

ADVANCED WORK AUTHORIZATION

\begin{tabular}{|c|c|c|c|c|c|c|}
\hline AWA-00-001 & $21-0 c t-99$ & Polycube Stabilization Testing & $\$ 500$ & $\bar{X}$ & $\mathrm{X}$ & $21-0 \mathrm{ct}-99$ \\
\hline AWA-00-002 & $22-\operatorname{Sep}-99$ & Residue Cementation & $\$ 500$ & $\bar{x}$ & $\mathrm{X}$ & $19-0 c t-99$ \\
\hline AWA-00-003 & $01-\operatorname{Jan}-10$ & Main Power Transformers & $\$ 350$ & $\bar{x}$ & & $31-\operatorname{Jan}-00$ \\
\hline AWA-00-004 & $01-\operatorname{Jan}-00$ & 2nd Bagless Transfer Unit & $\$ 500$ & $\mathbf{x}$ & $\bar{X}$ & 11 -Feb- 00 \\
\hline AWA-00-005 & $06-\mathrm{Mar}-00$ & 2nd Bagless Transfer Unit & $\$ 500$ & $\bar{X}$ & $\overline{\mathrm{X}}$ & 8-Mar-00 \\
\hline
\end{tabular}

\section{MILESTONE ACHIEVEMENT}

\begin{tabular}{|c|c|c|c|c|c|c|c|c|}
\hline \multirow[b]{2}{*}{ MILESTONE TYPE } & \multicolumn{4}{|c|}{ FISCAL YEAR-TO-DATE } & \multicolumn{3}{|c|}{ REMAINING SCHEDULED } & \multirow[b]{2}{*}{$\begin{array}{l}\text { TOTAL } \\
\text { FY } 2000\end{array}$} \\
\hline & $\begin{array}{c}\text { Completed } \\
\text { Early }\end{array}$ & $\begin{array}{c}\text { Completed } \\
\text { On } \\
\text { Schedule }\end{array}$ & $\begin{array}{l}\text { Completed } \\
\text { Late }\end{array}$ & Overdue & $\begin{array}{c}\text { Forecast } \\
\text { Early }\end{array}$ & $\begin{array}{c}\text { Forecast } \\
\text { On } \\
\text { Schedule }\end{array}$ & $\begin{array}{c}\text { Forecast } \\
\text { Late }\end{array}$ & \\
\hline Enforceable Agreement & 7 & 0 & 0 & 0 & 0 & I & 0 & 2 \\
\hline DOE-HQ & 이 & 0 & 0 & $T$ & o & 0 & 0 & $T$ \\
\hline RL & of & of & 0 & 0 & 0 & 9 & 0 & 9 \\
\hline Total Proiect & 1 & 0 & 0 & 1 & $\overline{0}$ & 10 & 0 & 12 \\
\hline
\end{tabular}

Tri-Party Agreement / EA Mfilestones

Tri-Party Agreement Milestone M-15-37A (TRP-00-501), "Deliver Two (2)

Tank Z-361 Core Samples to 222-S", due 10/30/99

Completed 1 month early $(9 / 28 / 99)$

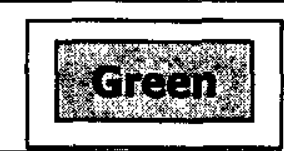

\section{DMTSB Commitments}

DNFSB Milestone IP-113 (TRP-00-500), "Install 2 LANL

Pyrolysis Units for Stabilization of Polycubes at PFP", due $12 / 31 / 99$

- Alternative path forward using PFP muffle furnaces being evaluated. Thermal stabilization testing at PNNL and PFP's PPSL underway consistent with approved AWA. Issued path forward recommendation to use direct thermal stabilization process versus pyrolysis.

- Letter issued to DOE-RL indicating milestone would not be met. 


\section{MILESTONE EXCEPTION REPORT}

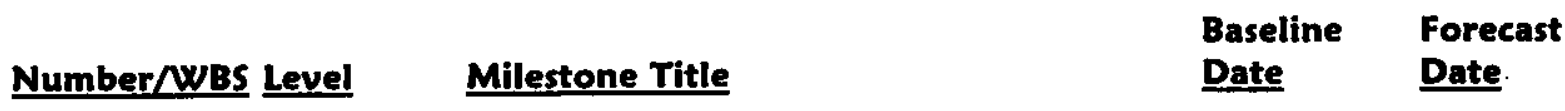

\section{OVerdue - 1}

$\begin{array}{llll}\text { TRP-00-500 HQ } & \text { Install Two LANL Pyrolysis Units for } & 12 / 31 / 99 & \begin{array}{l}\text { Proposed } \\ \text { Deletion }\end{array}\end{array}$

Cause: See DNFSB Commitment above.

Corrective Action: Thermal stabilization testing at Hanford's Pacific Northwest National Laboratory and the Plutonium Finishing Plant's Plutonium Process Support Laboratories is underway with an approved Advance Work Authorization. A baseline change request has been prepared documenting this change in polycube stabilization methodology and is in the DOE-RL approval process (i.e., this BCR was approved in March 2000).

\section{FY 1999 OVERDUE - 2}

$\begin{array}{llll}\text { TRP-99-419 RL } & \begin{array}{l}\text { Complete Installation of Production } \\ \text { Scale Vertical Calciner }\end{array} & 09 / 30 / 99 & \begin{array}{l}\text { Proposed } \\ \text { Deletion }\end{array}\end{array}$

Cause: The production scale vertical calciner has been replaced with the Magnesium Hydroxide Precipitation process.

Impact: No impact. This milestone is obsolete.

Corrective Action: Since installation and testing of the production scale vertical calciner is an EM65 Management Commitment, the Department of Energy, Richland Office (DOE-RL) change control process cannot remove this milestone.

TRP-99-500 HQ Complete Installation \& Testing of 09/30/99 Proposed
1.4.5
Production Vertical Calciner
Deletion

Cause: The production scale vertical calciner has been replaced with the Magnesium Hydroxide Precipitation process.

Impact: No impact. This milestone is obsolete.

Corrective Action: Since this milestone is a DOE-HQ milestone and is part of the DOE-HQ 1998 DNFSB Recommendation 94-1 Implementation Plan, the Department of Energy, Richland Office change control process cannot remove this milestone. However, this milestone will be removed upon approval of the revised DOE-HQ DNFSB Recommendation 94-1 Implementation Plan. 


\section{Performance Objectives}

\section{Oxides/Metals/Polycubes Stabilization}
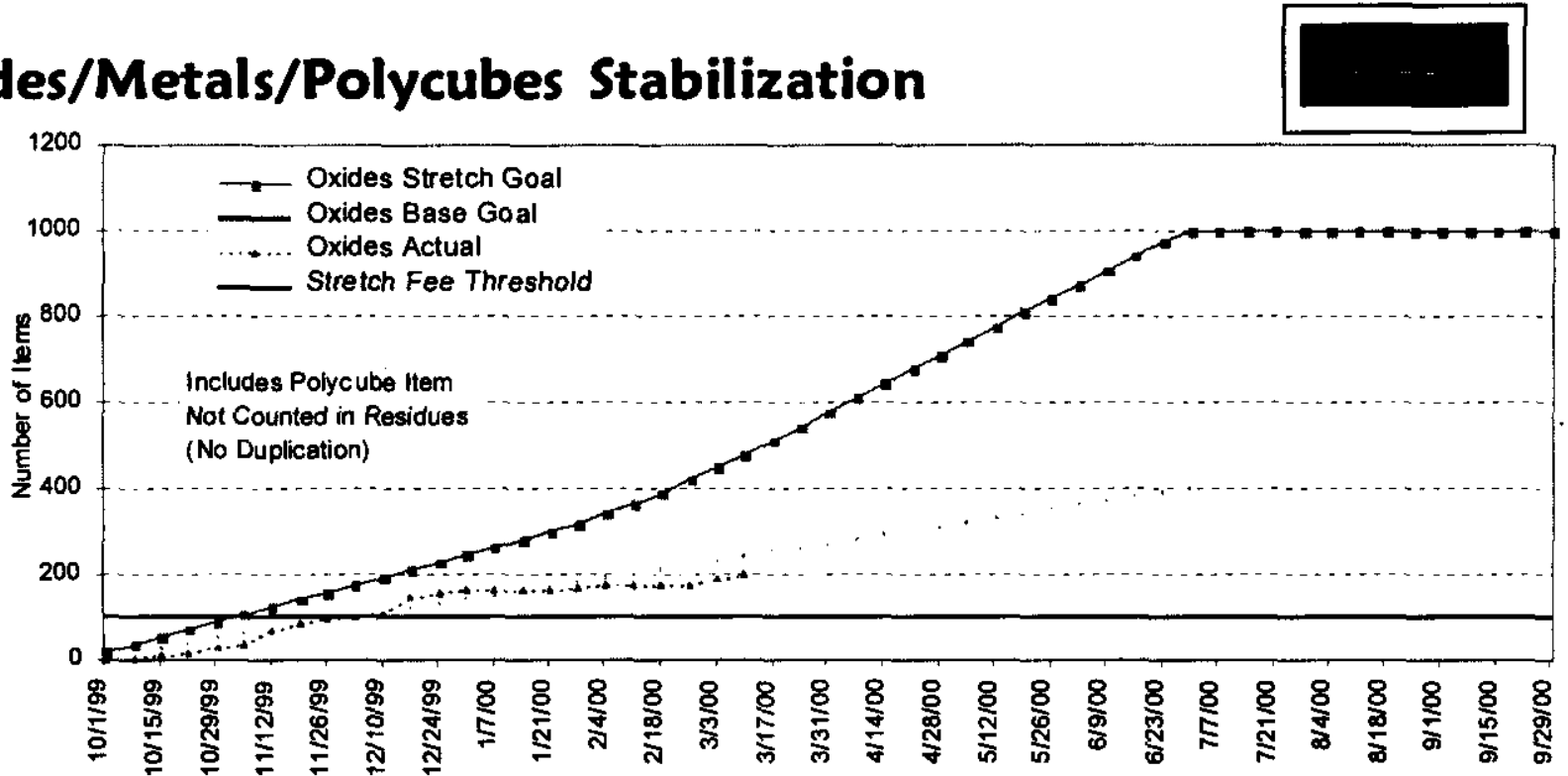

\begin{tabular}{|c|c|c|c|c|c|c|c|c|c|c|c|c|c|c|c|c|c|c|c|c|c|c|c|c|c|}
\hline & $10 / 9$ & $10 / 15$ & 1028 & $11 / 12$ & $11 / 28$ & $12 / 17$ & $12 / 31$ & $1 / 4$ & $1 / 28$ & $2 / 11$ & $2 / 25$ & $3 / 10$ & $3 / 24$ & $4 / 14$ & $4 / 28$ & $5 / 12$ & $5 / 28$ & $B A$ & 623 & 77 & $7 / 21$ & $8 M 1$ & $8 / 25$ & $9 / 8$ & $8 / 22$ \\
\hline Oxides Stretch Goal & 18 & 53 & 88 & 123 & 159 & 212 & 247 & 282 & 318 & 368 & 420 & 478 & 545 & 644 & 710 & 778 & 842 & 908 & 975 & 1000 & 1000 & 1000 & 1000 & $\overline{1000}$ & 1000 \\
\hline Oxides Bese Goal & 10.1 & 30.2 & 50.4 & 70.8 & 90.7 & 121.0 & 141.1 & 1643 & 181.4 & 201,8 & 221.8 & $\longdiv { 2 4 1 . 9 }$ & 262.1 & 292.3 & 312.5 & 332.6 & 352.8 & 373.0 & 393.1 & & & & & & \\
\hline Strotch Foe Threshold & 100 & 100 & 100 & 100 & 100 & 100 & 100 & 100 & 100 & 100 & 100 & 100 & 100 & 100 & 100 & 100 & 100 & 100 & 100 & 100 & 100 & 100 & 100 & 100 & $10 \overline{0}$ \\
\hline
\end{tabular}

\section{SOLUTION STABILIZATION}

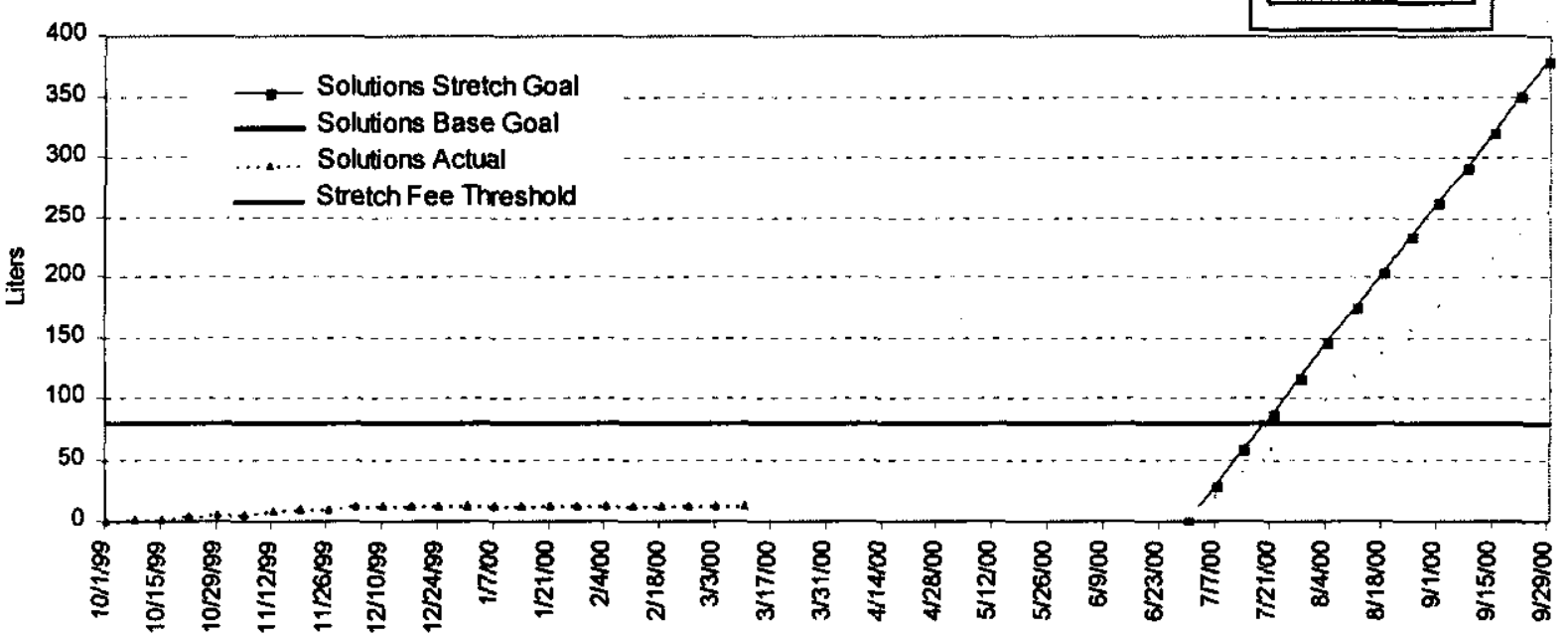

\begin{tabular}{|c|c|c|c|c|c|c|c|c|c|c|c|c|c|c|c|c|c|c|c|c|c|c|c|c|}
\hline & $10 / 1$ & $10 / 15$ & $10 / 29$ & $11 / 19$ & $12 / 3$ & $12 / 17$ & $12 B 1$ & $1 / 14$ & $2 / 4$ & $2 / 18$ & $3 / 3$ & $3 / 17$ & $4 / 7$ & $4 / 21$ & $5 / 5$ & $5 / 19$ & $6 / 2$ & $6 / 23$ & $7 \pi$ & $7 / 21$ & $8 / 4$ & $8 / 18$ & 9R & $9 / 22$ \\
\hline Solutions Stretch Goal & & & & & & & & & & & & & & & & & & & 29.2 & 87.6 & 146 & 20.4 & 292 & 350.4 \\
\hline Solutions Base Goal & & & & & & & & & & & & & & & & & & & 18.6 & 58.8 & 98.0 & 437.2 & 196.0 & 235.2 \\
\hline Solutions Actual & 0 & 2 & 5 & 8 & 12 . & 13 & 13 & 13 & $1 \overline{3}$ & 13 & 13 & & & & & & & & & & & & & \\
\hline Stretch Foe Threshold & 80 & 80 & 80 & 80 & 80 & 80 & $\overline{B O}$ & 80 & 80 & 80 & 80 & 80 & BO & 80 & 80 & 80 & 80 & 80 & 80 & 80 & 80 & 80 & 80 & 80 \\
\hline
\end{tabular}

Aggressively pursuing construction completion in support of stabilization activities. 


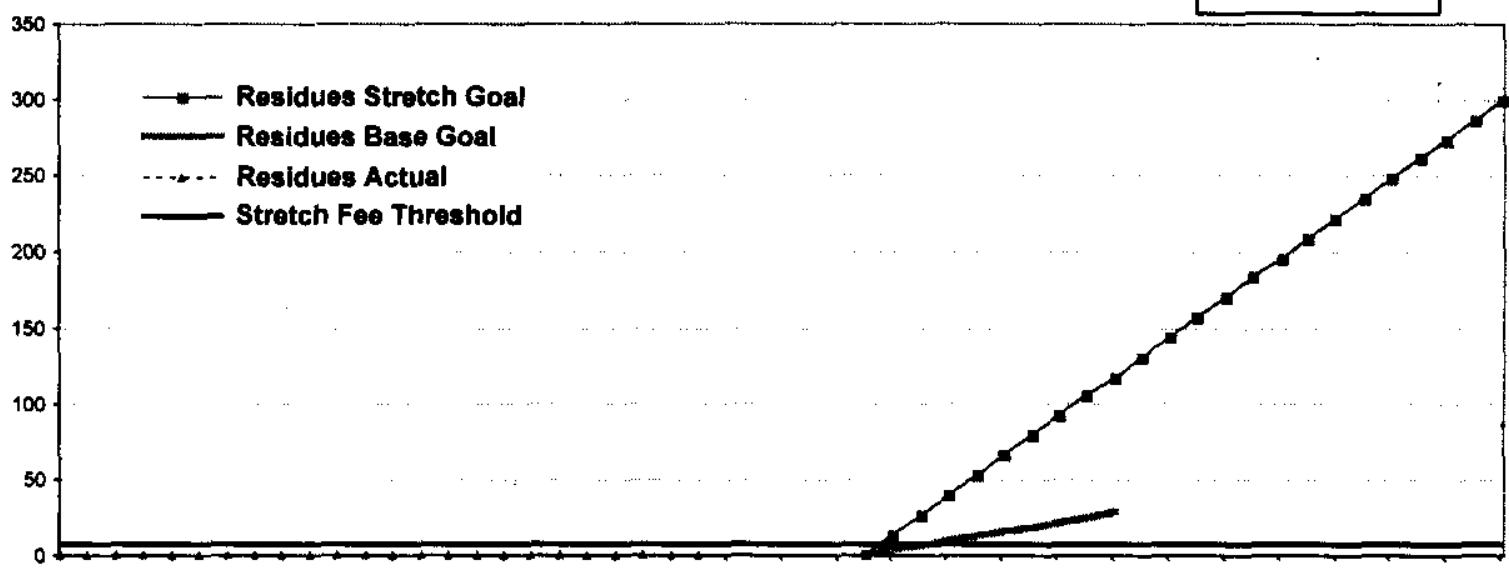

\begin{tabular}{|c|c|c|c|c|c|c|c|c|c|c|c|c|c|c|c|c|c|c|c|c|c|c|c|c|}
\hline & $10 / 1$ & $10 / 15$ & tor29 & 11119 & $12 / 3$ & $12 / 17$ & 12331 & $1 / 14$ & $2 / 4$ & $2 / 18$ & $3 / 3$ & $3 / 17$ & $4 / 7$ & $4 / 21$ & 5/5 & $5 / 10$ & $6 / 2$ & $6 / 23$ & $7 \pi$ & $7 / 21$ & 8/4 & $8 / 18$ & 98 & $9 / 22$ \\
\hline Residues Stretch Goed & & & & & & & & & & & & & & 0 & 27.2 & 53.2 & 79.2 & 118.2 & 144.2 & 170.2 & 193.2 & 222,2 & 281.2 & 287.2 \\
\hline Rogidues Bene Gool & & & & & & & & & & & & & & 0 & 7 & 13 & 19 & 28 & & & & & & \\
\hline Residues Actual & 0 & 0 & 0 & 0 & 0 & 0 & 0 & 0 & 0 & 0 & 0 & & & & & & & & & & & & & \\
\hline \begin{tabular}{|l|} 
Strotch Fee Threstrold \\
\end{tabular} & 7 & 7 & 7 & 7 & 7 & 7 & 7 & 7 & 7 & 7 & 7 & 7 & 7 & 7 & 7 & 7 & 7 & 7 & 7 & 7 & 7 & 7 & 7 & 7 \\
\hline
\end{tabular}

Currently working Central Waste Complex / WIPP Acceptance and RCRA permitting issues.

\section{KEY INTEGRATION ACTIVITIES}

- Continue working with PNNL on activities associated with the $\mathrm{Mg}(\mathrm{OH})_{2}$ process and polycube stabilization issues

- Continue discussions with Waste Management regarding Waste Isolation Pilot Program certification 

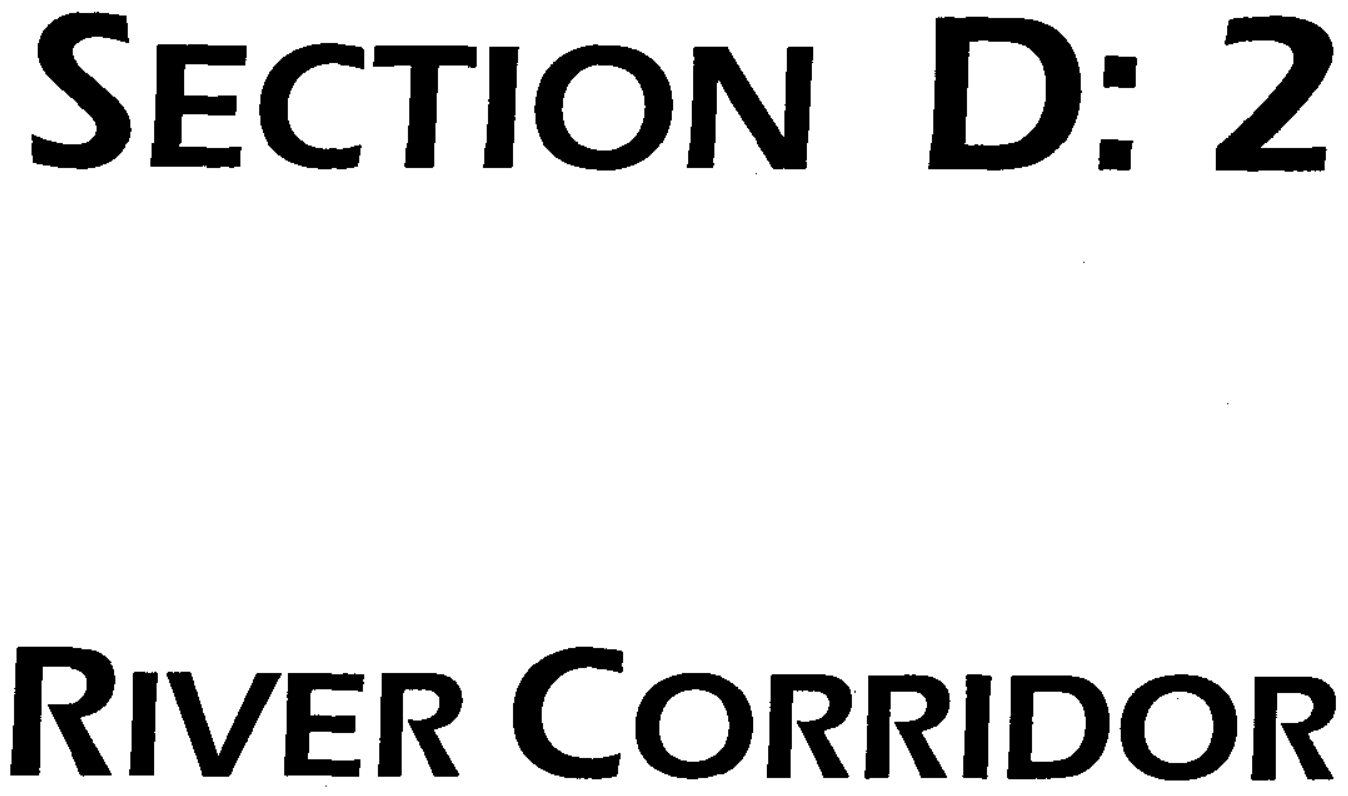

PROJECT MANAGERS

\author{
P. M. Knollmeyer, RL \\ Phone: (509) 376-7435
}

N. Boyter, FH

Phone: (509) 373-3725 


\section{SUMMARY}

The River Corridor Project consists of the following projects: 300 Area Liquid Effluent Facility (LEF) WBS 1.2.3.2, Project Baseline Summary (PBS) WM05; B-Plant, WBS 1.4.1, PBS TP01; 300 Area/Special Nuclear Materials, WBS 1.4.4, PBS TP04; Transition Project Management, WBS 1.4.6, PBS TP12; Accelerated Deactivation, WBS 1.4.8, PBS TP10; 324/327 Facility Transition, WBS 1.4.10, PBS TP08; and Hanford Surplus Facility Program (300 Area Revitalization), WBS 1.4.11, PBS TP14.

PBS WM05 is divided between WBS 1.2.3.1, Liquid Effluents (200 LEF) and WBS 1.2.3.2, 310 TEDF/340 Facility (300 LEF). The 310 TEDF/340 Facility work scope is now included in the River Corridor Project, whereas the Liquid Effluents (200 LEF) work scope has remained in Waste Management. For the purpose of performance analysis, PBS WM05 is reported in Waste Management, which has the majority of the work scope and funding incorporated in their baseline.

NOTE: Unless otherwise noted, the Safety, Conduct of Operations, and Cost/Schedule data contained herein is as of February 29, 2000. All other information is as of March 21, 2000.

Good progress was made toward closeout of the actions required by the B Plant transfer Memorandum of Agreement (MOA). All 18 filters in the \#2 filter train were tested and passed. All prerequisite actions for the cracked exhaust duct testing are complete. However, the impact of the cracked exhaust duct may cause a delay to completion of the B Plant turnover MOA.

The Project Management Institute's Regional Project of the Year Award was presented to the 300 Area Fuel Supply Shutdown Waste Acid Treatment System (WATS) Resource Conservation and Recovery Act of 1976 (RCRA) Closure Project.

Progress continues toward Accelerated Deactivation of the 327 Facility. The removal of $\sim 116$ of -300 sample cans from Dry Storage was completed. Additionally, a revision was submitted to the compacted low-level waste profile. This revision will result in a disposal savings by allowing waste previously shipped as Category 3 (\$49.16 per cubic foot), to be shipped as Category 1 (\$12.14 per cubic foot).

The 2A rack was successfully removed from the $\mathrm{B}$ Cell wall. This included High-Efficiency Particulate Air filter and Electrostatic Precipitator removal/replacement. Excellent progress is being made on size reduction of the rack. As of $3 / 23 / 00$, nearly $80 \%$ of the rack had been reduced. Ninety percent of one tank within the rack has been removed and less than half of the other tank remains. Currently, four grout containers are filled with 2A Rack material.

The 324 Building team completed its first shipment since the fall of 1998 when grout container \#136 was shipped to the 200 Area. This shipment closes out all waste characterization and packaging, and shipping issues that have confronted the 324 team for the past $11 / 2$ years. 
The Accelerated Deactivation project is making good progress in planning for the disposition of approximately 1,865 metric tons (MT) of Hanford Unirradiated Uranium. Responses to public comments on the Environmental Assessment (EA) are being coordinated. Additionally, the Hanford Advisory Board was briefed on the intent to bury non-contaminated fuel at the LowLevel Burial Ground (LLBG), potentially saving in excess of $\$ 1 \mathrm{M}$ over the original baseline. Final disposition of Unirridiated Uranium fuel elements to low-level waste burial grounds vs. packaging and transportation to Portsmouth, Ohio for interim storage provides the method to save in excess of $\$ 1 \mathrm{M}$ over the current Project Management Plan cost baseline. If funded and regulatory concurrence is received, disposition of the Uranium fuel elements will occur in the last quarter of FY 2000. Another consideration for savings is to consolidate shipments of Uranium billets and Uranium Oxide powder, which will save approximately $40 \%(\$ 200 \mathrm{~K})$ of the planned transportation cost to Portsmouth, Ohio. If funding is identified to support this initiative, shipment of the material to Portsmouth will occur in the June/July 2000 time frame. Currently, Phase I activities to prepare uranium billets and UO3 T-hoppers for shipment are continuing.

The Project Management Plan for the 300 Area Special Case Waste, HNF-5068, Revision 1, was received at RL. Finalization of this document completes two Tri-Party Agreement interim milestones, M-92-13, "Submit 300 Area SCW Project Management Plan," and M-92-14, "Project Management Plan for the 300 Area Special Case Waste."

A presentation introducing the National Facility Deactivation Initiative Decontamination \& Decommissioning tools was made in the introductory session of a Washington State Universitysponsored course on D\&D. A more complete presentation on end points and the Planning, Optimizing, Waste Estimating, and Resourcing tool (POWERtool) will be provided during the course. Plans are to give the participants hands on experience with identifying end points and using the POWERtool through examples. A presentation will be made on characterization with examples of characterization activities that were not really needed, and to emphasize the message that it is necessary to scrutinize D\&D activities to ensure that there is a driver for each activity being done. A National Facility Deactivation Initiative (NFDI) presentation will also be made during the concluding session.

Fiscal-year-to-date milestone performance (EA, DOE-HQ, and RL) shows that three of three milestones (100 percent) were completed on or ahead of schedule. The Milestone Achievement details, found following cost and schedule variance analysis, provide further information on all milestone types.

\section{ACCOMPLISHMENTS}

- 2A rack removed from B Cell wall. As of March 27, 2000 size reduction of the rack was $80 \%$ complete. The High-Efficiency Particulate Air Filter and Electrostatic Precipitator was removed/replaced with notification to the Washington State Department of Health on March 3, 2000.

- $\quad 324$ completed first shipment since fall of 1998 when grout container \#136 was shipped to the 200 Area. 
- Treatment of the first of two diversion storage tanks of water impacted by the citrate acid upset in the 310 Liquid Effluent Treatment Facility started as planned on March 15, 2000, without incident. The process is operating as expected and in compliance with permit conditions.

- Completed the removal of $\sim 116$ of $\sim 300$ sample cans from Dry Storage at 327 Building.

- Public comments on Uranium Disposition Environmental Assessment have been received and reviewed. There are no show stopper comments.

- U.S. Department of Energy - Headquarters, has received revision 1 of the Uranium billet disposition Safety Analysis Report for Packaging (SARP) for review and approval.

- $\quad$ RL Manager, K. A. Klein, approved the 300 Area Accelerated Closure Project Plan baseline change request (FSP-2000-024).

- The 300 Area Special Case Waste, HNF-5068, Project Management Plan, Revision 1 was transmitted to RL. Finalization of this document completes two Tri-Party Agreement interim milestones, M-92-13 and M-92-14.

- The 300 Area Fuel Supply Shutdown Waste Acid Treatment System (WATS) Resource Conservation and Recovery Act of 1976 (RCRA) Closure Project was selected as Project Management Institute's Regional Project of the Year award winner.

\section{SAFETY}

Significant Decreases in OSHA recordable case rate and in DOE Safety Cost Index have recently occurred. The project is approaching 500,000 hours without an OSHA recordable.

The project has an overall green rating - stable at good rates. 

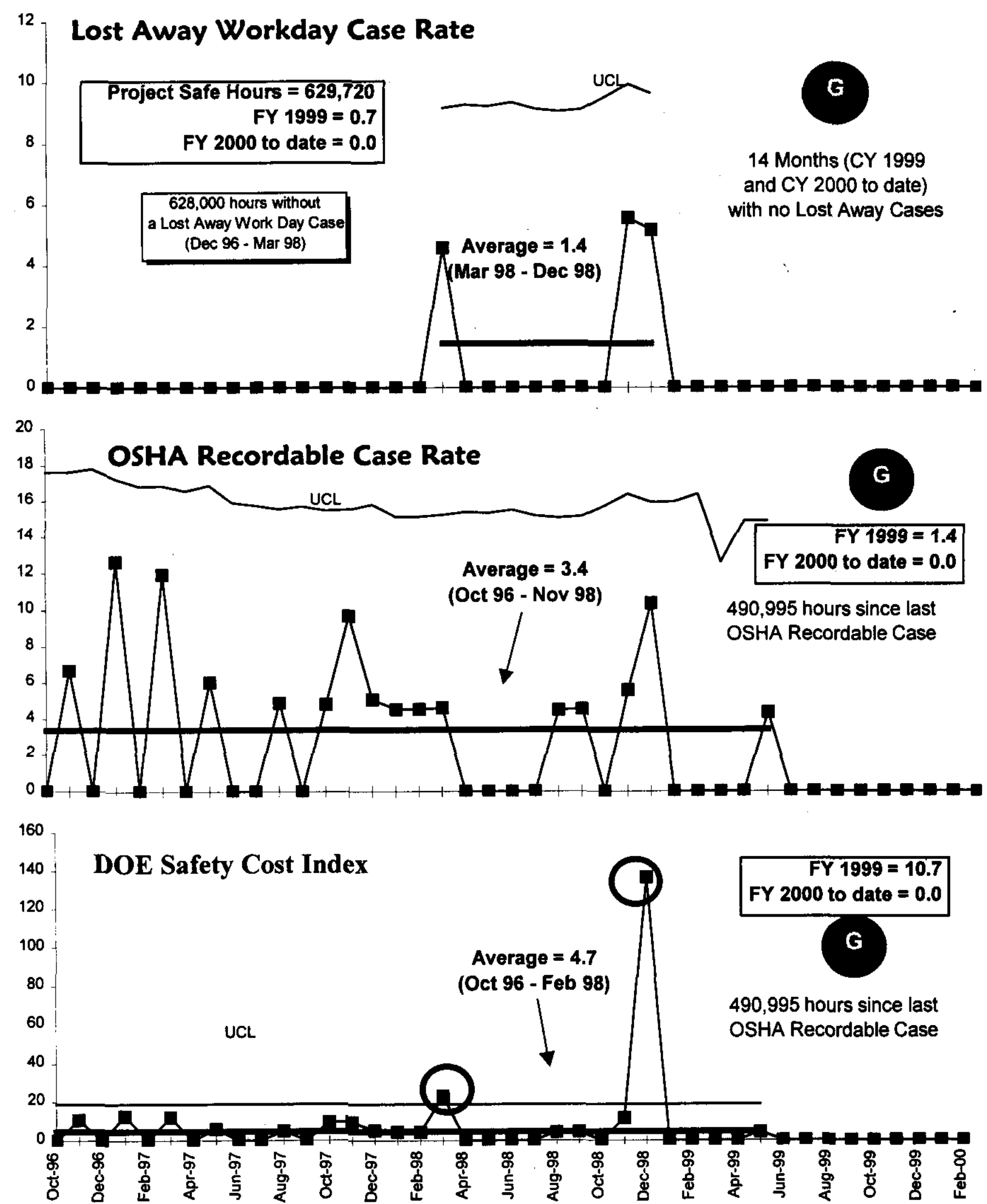


\section{CONDUCT OF OPERATIONS / ISMS STATUS}
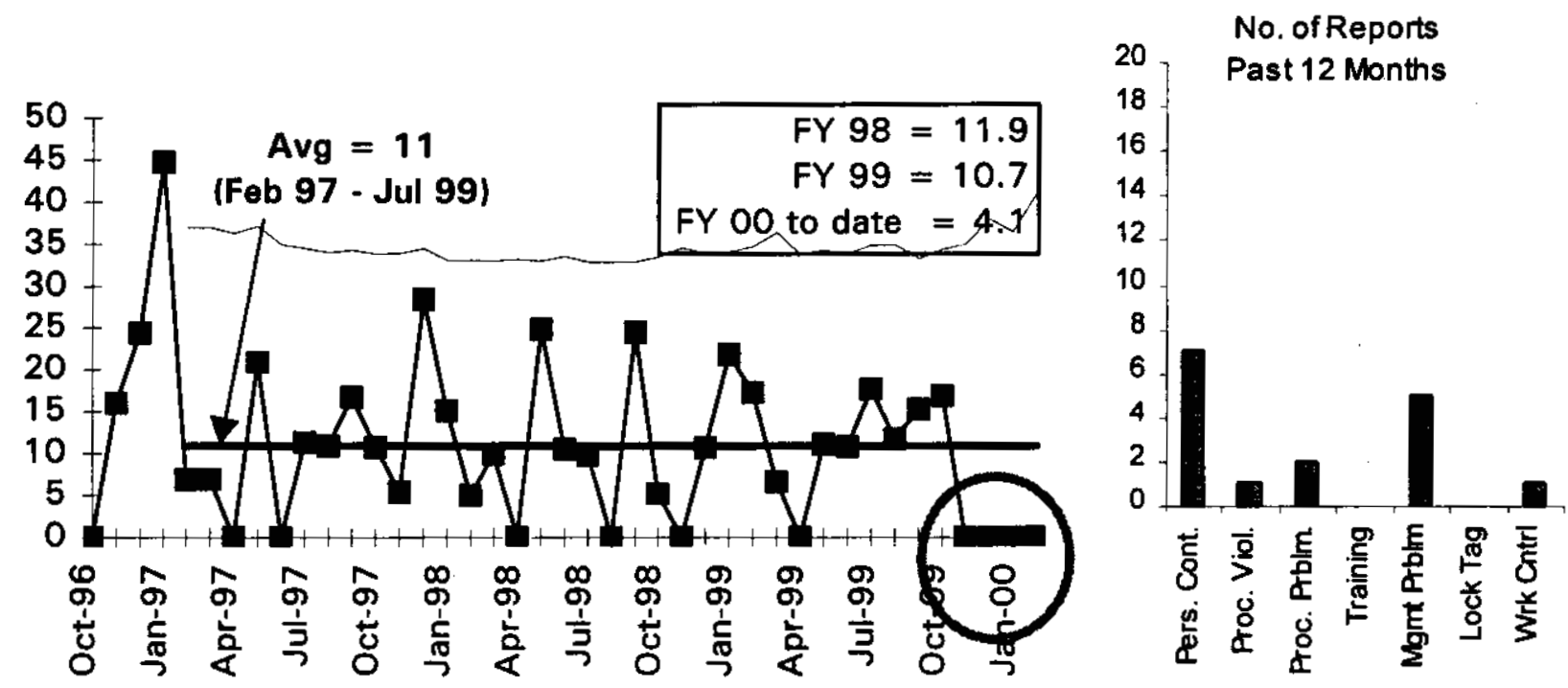

\section{ISMS STATUS}

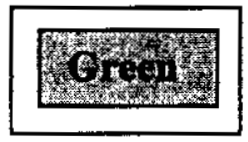

- ISMS Internal Readiness Review (IRR) completed; closure plan in progress.

- Senior Management Review Board presentations completed.

- Board's recommendation for readiness is targeted for 3/31/00.

- No concerns identified.

- 14 opportunities for improvement being worked.

- ISMS Verification targeted for May 2000.

\section{BREAKTHROUGHS / OPPORTUNITIES FOR IMPROVEMENT}

\section{BREAKTHROUGHS}

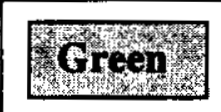

- Savings Through Alternative Disposition Strategy - Final disposition of Unirridiated Uranium fuel elements to low-level waste burial grounds vs. packaging and transportation to Portsmouth, Ohio for interim storage will save in excess of $\$ 1 \mathrm{M}$ over the current Project Management Plan cost baseline. If funded and regulatory concurrence is received disposition of the Uranium fuel elements will occur in the last quarter of FY 2000.

- $\quad 340$ Efficiencies - Efficiency initiatives have been identified to fund critical deactivation activities, i.e., Vault Tank $1 \& 2$ removal of residual heels $(\sim 3,000$ gallons). If given timely approval (April 2000) to proceed via super stretch AWA/BCR, this effort will be completed by September 2000; a three year acceleration. 


\section{OPPORTUNITIES FOR IMPROVEMENT}

- 324 Project Planning / Execution: Despite recent success in schedule recovery, there is a need for continued emphasis on improved schedule management to ensure that critical path negative float is recovered to positive float. Current actions are directed at organization shift to projects and improving crane availability.

- Consolidating Uranium Shipments - Consolidating shipments of Uranium billets and Uranium Oxide powder will save approximately $40 \%(\$ 200 \mathrm{~K})$ off the planned transportation cost to Portsmouth, Ohio. If funding is identified to support this super stretch initiative, shipment of the material to Portsmouth will occur in the June/July 2000 time frame.

\section{UPCOMING ACTIVITIES}

- B Plant Transfer to ERC - Complete all closeout activities (ventilation system repairs) by March 2000 .

- 340 Facility Deactivation - Process baseline change request April 2000, and initiate vault tank cleanout of residual tank heels.

- Multi-site Joint Committee Meeting - Host DOE complex-wide National Facility Deactivation Initiative and Decommissioning \& Decontamination Committee Meeting April 25 through 27, 2000.

- Integrated Environmental, Safety \& Health System (ISMS) - Complete verification of Phase I \& II readiness activities by May $15,2000$.

- 300 Area Accelerated Closure Project Plan - Prepare and issue the 300 Area Accelerated Closure Project Plan, schedule and estimate June 30, 2000.

- 300 Area Waste Acid Treatment System (WATS) Resource Conservation and Recovery Act (RCRA) Closure Activities - Final report is due to RL March 31, 2000. However, the review and comment cycle with Washington Department of Ecology (WDOE) is expected to delay report submittal until September 2000.

- $\quad$ TPA Milestone M-89-02 - Complete Removal of 324 Building Radiochemical Engineering Cell (REC) B Cell Mixed Waste (MW) and Equipment by November 2000 . 


\section{Cost Performance (\$M):}

\begin{tabular}{|l|c|c|c|}
\hline & BCWP & ACWP & VARIANCE \\
\hline River Corridor Project & $\$ 20.7$ & $\$ 20.9$ & $-\$ 0.2$ \\
\hline
\end{tabular}

The $\$ 0.2$ million (1.0 percent) unfavorable cost variance is within the established threshold. Further information at the PBS level can be found in the following Cost Variance Analysis details.

\section{Schedule Performance (\$M):}

\begin{tabular}{|l|c|c|c|}
\hline & BCWP & BCWS & VARIANCE \\
\hline River Corridor Project & $\$ 20.7$ & $\$ 21.0$ & $-\$ 0.4^{*}$ \\
\hline
\end{tabular}

The $\$ 0.4$ million (2.0 percent) unfavorable schedule variance is within the established threshold. Further information at the PBS level can be found in the following Schedule Variance Analysis details.

\section{WBS 1.4.1, 1.4.4, 1.4.6, 1.4.8, 1.4.10, 1.4.11 FY 2000 Cost/Schedule Performance - All Fund Types Cumulative to Date Status - (\$000) FYTD}

By PBS

\begin{tabular}{|c|c|c|c|c|c|c|c|c|c|c|c|c|c|c|c|}
\hline $\mathrm{TP} 01$ & B-Plant & $\$$ & - & $\$$ & - & $\$$ & 314 & $\$$ & - & $0 \%$ & $\mathbb{\$}$ & (314) & $0 \%$ & $\$$ & - \\
\hline TP04 & 300 Area/ SNM & $\$$ & 1,036 & $\$$ & 1,033 & $\$$ & 1,063 & $\$$ & (3) & $0 \%$ & $\$$ & $(30)$ & $-3 \%$ & $\$$ & 2,686 \\
\hline TP12 & Program Mgmt & $\$$ & 7,371 & $\$$ & 7,415 & $\$$ & 5,907 & $\$$ & 44 & $1 \%$ & $\$$ & 1,508 & $20 \%$ & $\$$ & 19,408 \\
\hline TP10 & $\begin{array}{l}\text { Accelerated } \\
\text { Deactivation }\end{array}$ & $\$$ & 934 & $\$$ & 936 & $\$$ & 828 & $\$$ & 2 & $0 \%$ & $\$$ & 108 & $12 \%$ & $\$$ & 2,430 \\
\hline TP08 & $\begin{array}{l}\text { 324/327 Bldg } \\
\text { Deactivation } \\
\text { HSFP 300A }\end{array}$ & $\$$ & 11,408 & $\$$ & 11,054 & $\$$ & 12,549 & $\$$ & (354) & $-3 \%$ & $\$$ & $(1,495)$ & $-14 \%$ & $\$$ & 34,596 \\
\hline TP14 & Revitalization & $\$$ & 292 & $\$$ & 235 & $\$$ & 192 & $\$$ & (57) & $-20 \%$ & $\$$ & 43 & $18 \%$ & $\$$ & 781 \\
\hline
\end{tabular}




\section{Cost / Schedule Performance Indices (FEBRUARY 2000 AND FYTD)}

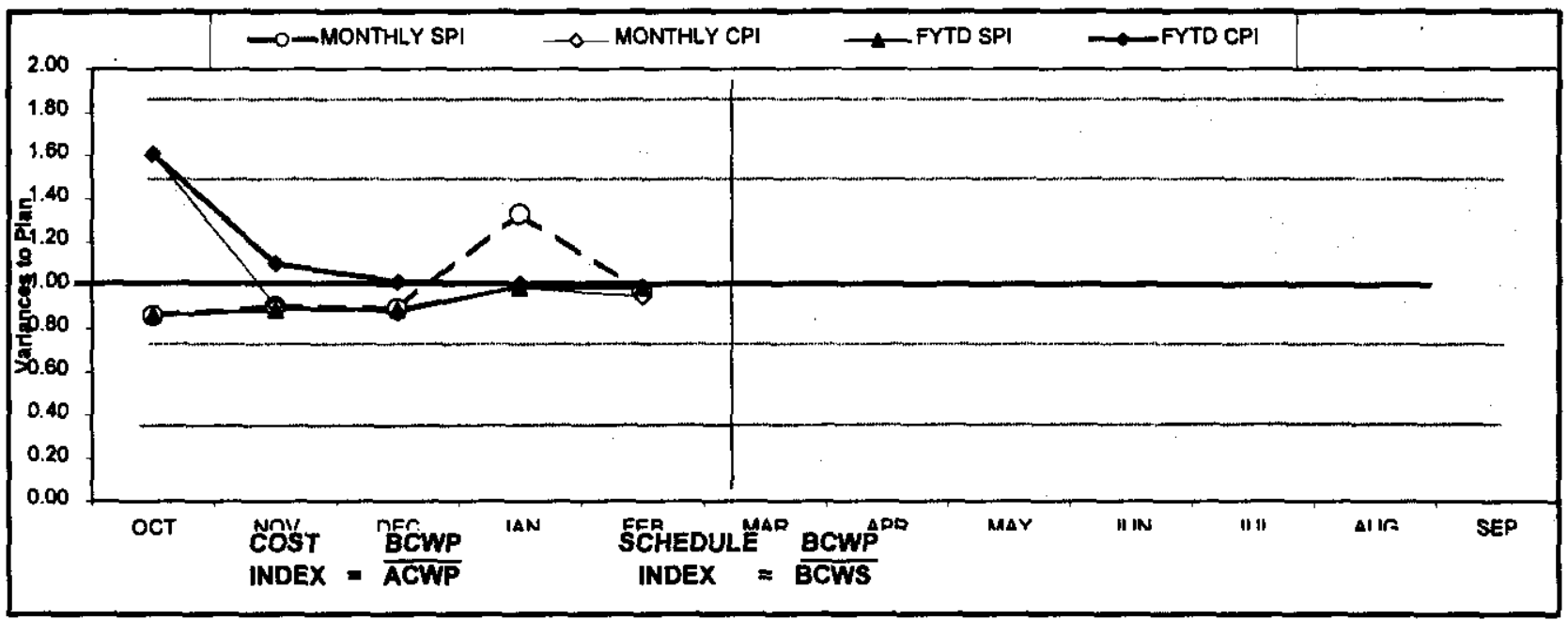

\begin{tabular}{|c|c|c|c|c|c|c|c|c|c|c|c|c|}
\hline FY200'0 & OCT & ToV & DEC & JAK & FEES & MAR & APR & TAY & JUN & JUL & AUS & S185 \\
\hline MONTRLYSPT & 0.86 & 0.800 & 0.89 & $T, 33$ & 0.85 & & & & & & & \\
\hline MONIRLYCPT & 1.60 & 0.901 & 0.87 & 0,86 & 0.95 & & & & & & & \\
\hline FYTOSPI & 0.86 & 0.88 & 0.89: & 0.99 & 0.88 & & & & & & & \\
\hline FYTOCPI & 1.60 & 7.10 & T.01 & T.00 & 0.99 & & & & & & & \\
\hline MONIFLYBCWS & 33,652 & 35.162 & $\$, 092$ & $\$ 3,858$ & 3,277 & & & & & & & \\
\hline MONTRLYBCWF & 33,134 & 34,650 & $\$ 5,647$ & 35,124 & \$.T15 & & & & & & & \\
\hline MONTRIYY ACWP & $\$ 1,954$ & 35,141 & 7,195 & $35,20 \%$ & 34,357 & & & & & & & \\
\hline FYTDECWS & $\$ 3,652$ & $\$ 6,84$ & $\$ 12,906$ & $\$ 16,764$ & 321,041 & & & & & & & \\
\hline FYTDECWP & $\sqrt{3,134}$ & $\$ 7,784$ & 511,431 & $\$ 16.555$ & $\$ 20,674$ & & & & & & & \\
\hline FYTOACWP & \$1,954 & $\$ 7,095$ & $\$ 11,290$ & 716,496 & $\$ 20,853$ & & & & & & & \\
\hline
\end{tabular}

\section{COST VARIANCE ANALYSIS: $(-\$ 0.2)$}

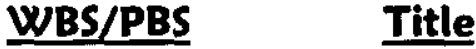

\subsection{1/TP01 B Plant}

Description and Cause: The unfavorable cost variance is due to unplanned costs associated with the ventilation filter change outs and ductwork repairs.

Impact: Deprives other projects of funding for current year priorities including accelerated deactivation activities.

Corrective Action: Work scope is being performed via an approved Advanced Work Authorization (AWA) while BCR FSP-00-008, which funds the B Plant action items, is dispositioned.

\subsection{6/TP12 Transition Project Management}

Description and Cause: The favorable cost variance is primarily due to the PHMC restructuring which has mapped personnel from the sub-project to other sub-projects (i.e. Nuclear Material Stabilization), resulting in underruns in labor and contractor support. While the project is reporting a favorable cost variance, the actual status for River Corridor is an unfavorable cost variance of $\$ 231 \mathrm{~K}$. 
Impact: The current Fiscal Year Spend Forecast (FYSF) projects a $\$ 1.2 \mathrm{M}$ unfavorable condition at fiscal year end for River Corridor.

Corrective Action: Re-planning of this account is underway to reflect the new structure, including the transfer of funds to other PHMC sub-projects where former Facility Stabilization personnel have been mapped. A BCR will be processed to document the split of the sub-project. If incremental funding is not identified RCP project impacts will be incurred.

\subsubsection{0/TP08 324/327 Building Deactivation}

Description and Cause: The unfavorable cost variance is primarily due to performance of unfunded accelerated 327 Building deactivation work scope via AWA (super stretch performance incentive). This is partially offset by efficiencies that are being realized in both the performance of MinSafe activities and deactivation scope.

Impact: None. Spending against AWAs is being closely monitored.

Corrective Action: Costs of work being performed via AWA will be measured against baseline performance once the applicable baseline change requests are approved.

\subsection{8/TP10 Accelerated Deactivation}

Description and Cause: The unfavorable cost variance is due to an incorrect accrual amount posted on the NFDI contract.

Impact: None.

Corrective Action: The incorrect accrual will be reversed and entered correctly in March.

\subsubsection{1/TP14 HSFP 300 Area Revitalization}

Description and Cause: The favorable cost variance is primarily due to less than planned costs in Min Safe surveillance and corrective maintenance activities.

Impact: None.

Corrective Action: Funds made available via underruns will be utilized toward achievement of accelerated deactivation activities.

All other PBS variances are within established thresholds.

\section{SCHEDULE VARIANCE ANALYSIS: $(-\$ 0.4)$}

\section{$\underline{\text { WBS/PBS }} \quad \underline{\text { Title }}$}

\subsubsection{1/TP14 HSFP 300 Area Revitalization}

Description and Cause: The unfavorable schedule variance is due to delays in performing the baseline estimate update activities. Changes in organization associated with the PHMC restructuring have caused the delay as a result of personnel performing other planned work either within sub-project or other areas.

Impact: None.

Corrective Action: The estimate update may not be required due to the 300 Area Accelerated Closure Plan Project planned via BCR FSP-2000-024, which was approved in March.

All other PBS variances are within established thresholds. 


\section{ISSUES}

\section{TECHNICAL ISSUES}

Issue: Shipping of ten grout containers filled with $1 \mathrm{~A}$ Rack to be completed by May 2000 . One has curie levels above limits allowed for shipment.

Impact: New Safety Analysis Report for Packaging (SARP) will be required for single high-curie container. RL Milestone TRP-99-907 currently states all 1A Rack grout containers are to be shipped by May 2000 .

Corrective Action: Informal negotiations have begun between $\mathrm{RL}$ and $\mathrm{FH}$ to substitute another container from the B Cell. Baseline Change Request being drafted; no funding or schedule change required.

Issue: The 324 Building Fire Hazards Analysis (FHA) revision supporting the 324 Building Safety Analysis Report (SAR) update resulted in revised combustible load limits.

Impact: There is a potential adverse cost impact to work progress at the 324 Building. Corrective Action: An implementation plan that allows work to continue while maintaining revised combustible load limits or invoking compensatory measures has been developed. Evaluation of alternative fire suppression capabilities to allow an increase in combustible load limits continues.

Issue: A crack was discovered on the new B Plant W-059 Duct Replacement.

Impact: Possible delay to completion of B Plant turnover Memorandum Of Agreement. Corrective Action: All 18 filters in \#2 filter train were tested and passed. All prerequisite actions for cracked exhaust duct testing are complete.

\section{DOE/REGULATOR/EXTERNAL ISSUES}

Issue: Approval by the U.S. Department of Energy - Headquarters (DOE-HQ) of the Unirradiated Uranium (UU) billet Safety Analysis Report for Packaging (SARP) is required by May 31, 2000. Performance Initiatives encourage the accelerated disposition of this material, however, review and approval time frames do not support attempts to accelerate shipments.

Impact: Failure to gain approval on or before May 31, 2000 will jeopardize the combined shipment of UU billets and T-Hoppers, thus losing the opportunity to save approximately $\$ 200,000$ in FY 2000. Performance Incentive RC3-SS Uranium Disposition will be impacted by the inability to ship billets and T-Hoppers in FY 2000. Corrective Action: A revision to the SARP, which limits the amount of criticality analysis, may expedite the review process. Timely DOE-HQ review and approval of billet Safety Analysis Report for Packaging (SARP) is critical for disposition. 


\section{Baseline Change Requests Currently in Process $(\$ 000)$}

\begin{tabular}{|c|c|c|c|c|c|c|c|c|c|}
\hline $\begin{array}{l}\text { PROIBCT } \\
\text { CHANGE } \\
\text { MMMER }\end{array}$ & $\begin{array}{l}\text { DATE } \\
\text { ORIGN }\end{array}$ & BCR IIIE & $\begin{array}{c}F Y O 0 \\
\text { OOST } \\
\text { IMPACT }\end{array}$ & $\mathrm{SCH}$ & $\mathrm{IECH}$ & $\begin{array}{l}\text { DATE } \\
\text { TOCCB }\end{array}$ & $\underset{\text { APRVD }}{\text { COB }}$ & $\begin{array}{c}\text { RL } \\
\text { APKVD }\end{array}$ & $\begin{array}{l}\text { CURRENT } \\
\text { STATUS }\end{array}$ \\
\hline $\begin{array}{l}\text { FSP-00002 } \\
\text { FSP-00008 } \\
\text { FSP-00009 } \\
\text { FSP-00013 } \\
\text { FSP-00021 } \\
\text { FSP-00002 } \\
\text { FSP-00-023 } \\
\text { FSP-00-024 } \\
\text { FSP-00-026 }\end{array}$ & $\begin{array}{l}11 / 2 / 99 \\
12 / 3199 \\
12 / 9199 \\
1 / 11 / 00 \\
1 / 27 / 00 \\
1 / 31 / 00 \\
2 / 6100 \\
2 / 1400 \\
2 / 29100\end{array}$ & 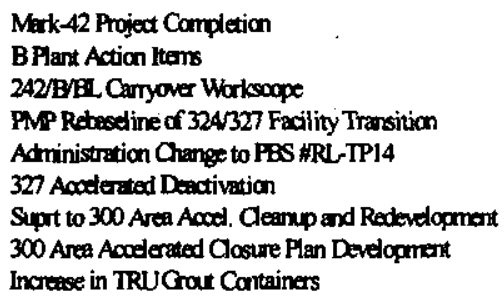 & $\begin{array}{r}\$ 295 \\
\$ 358 \\
\$ 36 \\
\$ 2,620 \\
\$ 92 \\
\$ \$ 0 \\
\$ 520 \\
\$ 2,170 \\
?\end{array}$ & $\mathrm{X}$ & $\begin{array}{l}\mathbf{X} \\
\mathrm{X} \\
\mathrm{X} \\
\mathrm{X}\end{array}$ & $\begin{array}{l}03 / 09100 \\
01 / 1900 \\
02 / 07 / 100 \\
03 / 07 / 00\end{array}$ & $\begin{array}{l}01 / 19 / 00 \\
02 / 1400 \\
03 / 07 / 00\end{array}$ & $\begin{array}{c}\text { O22400 } \\
\text { NA } \\
0310900\end{array}$ & $\begin{array}{l}\text { Under revision } \\
\text { Under revision } \\
\text { BCR to be revised } \\
\text { In reviewcyde } \\
\text { In reviewcyde } \\
\text { In reviewgyde } \\
\text { In Development }\end{array}$ \\
\hline \multicolumn{10}{|c|}{ ADVANCE WORKAUTHORIZATIONS } \\
\hline $\begin{array}{l}\text { AWA } \\
\text { AWA }\end{array}$ & $\begin{array}{l}10 / 1 / 99 \\
2 / 2400\end{array}$ & $\begin{array}{l}327 \text { Stabilizrition/Deactivation Project } \\
\text { Uranium Disposition Project }\end{array}$ & $\begin{array}{r}\$ \$, 500 \\
\$ 50\end{array}$ & $\begin{array}{l}\bar{X} \\
\mathbf{X}\end{array}$ & $\begin{array}{l}\bar{X} \\
\mathbf{X}\end{array}$ & & & $\begin{array}{l}0207100 \\
0310200\end{array}$ & $\begin{array}{l}\text { BCR HFSP-00020 } \\
\text { BCR not yet started }\end{array}$ \\
\hline
\end{tabular}

\section{MILESTONE ACHIEVEMENT}

\begin{tabular}{|c|c|c|c|c|c|c|c|c|}
\hline \multirow[b]{2}{*}{ MILESTONE TYPE } & \multicolumn{4}{|c|}{ FISCAL YEAR-TO-DATE } & \multicolumn{3}{|c|}{ REMAINING SCHEDULED } & \multirow[b]{2}{*}{$\begin{array}{c}\text { TOTAL } \\
\text { FY } \\
2000\end{array}$} \\
\hline & $\begin{array}{c}\text { Completed } \\
\text { Early }\end{array}$ & $\begin{array}{l}\text { Completed } \\
\text { On Schedule }\end{array}$ & $\begin{array}{l}\text { Completed } \\
\text { Late }\end{array}$ & Overdue & $\begin{array}{c}\text { Forecast } \\
\text { Early }\end{array}$ & $\begin{array}{c}\text { Forecast } \\
\text { On } \\
\text { Schedule }\end{array}$ & $\begin{array}{c}\text { Forecast } \\
\text { Late }\end{array}$ & \\
\hline Entorceable Agreement & 1 & 0 & 0 & 0 & 0 & of & of & \\
\hline DOE-HQ & 0 & 0 & 0 & 0 & 0 & of & 이 & \\
\hline RL & 0 & T & 0 & 0 & 0 & 3 & Tा & \\
\hline Total Project & 1 & 1 & 0 & 0 & 0 & 3 & 1 & \\
\hline
\end{tabular}

Tri-Party Agreement/ EA Milestones

M-092-13 (TRP-00-902), "Submit 300 Area SCW Project Management Plan," due 9/29/00 --Completed 10 months early $(11 / 30 / 99)$

M-89-02 (TRP-99-901), "Complete Removal of 324 Building Radiochemical Engineering Cells (REC) B Cell Mixed Waste (MW) and Equipment," due 11/30/00 --- The slip caused by A Cell crane failure has been recovered. The schedule was recovered by expediting A Cell crane repair procurement activities, putting the A Cell Crane back into limited service, and accelerating the incell shuttle box segregation from July.

Nothing to report. 


\section{MILESTONE EXCEPTION REPORT}

\section{OVerdue - 0}

\section{FORECAST LATE - 1}

\section{TRP-99-301 RL Submit Final Report on WATS Closure $\quad 03 / 31 / 00 \quad 09 / 29 / 00$}

\subsubsection{Activities to DOE-RL}

Cause: This report must include information obtained after the WDOE approves the Hanford Site RCRA permit which also includes the WATS permit. WDOE approval is not expected until late spring, consequently delaying the final report submittal until September 2000.

Impact: No impact. Does not delay any fieldwork.

Corrective Action: None at this time.

\section{Performance Objectives}

\begin{tabular}{|c|c|c|}
\hline Outcome & Performance Indicator & Status \\
\hline \multirow{3}{*}{$\begin{array}{l}\text { Restore } \\
\text { the River } \\
\text { Corridor } \\
\text { for } \\
\text { Multiple } \\
\text { Uses }\end{array}$} & $\begin{array}{l}\text { Accelerate } 324 / 327 \\
\text { Deactivation }\end{array}$ & $\begin{array}{l}\text { This initiative was initiated to measure the performance against the life cycle } \\
\text { baseline for the } 324 / 327 \text { Buildings Shutdown Project. As of February month- } \\
\text { end the life cycle SV and CV for the project was } 0.0 \% \text {. The critical path } \\
\text { showed a } 15 \text {-day positive float condition. }\end{array}$ \\
\hline & $\begin{array}{l}\text { Continue Acceleration of } \\
324 / 327 \text { Deactivation - } \\
\text { Complete } 327 \text { Facility } \\
\text { accelerated deactivation } \\
\text { activities by September } \\
2000 \text {. }\end{array}$ & $\begin{array}{l}\text { Good progress is being made in cleanout and packaging of legacy waste. } \\
\text { However, lack of confirmed funding for this effort jeopardizes completion of } \\
\text { these activities (via approved AWA). The } 327 \text { Facility has developed a plan } \\
\text { to reduce MinSafe costs to cover a portion of this work scope while efforts to } \\
\text { identify remaining funds continue. }\end{array}$ \\
\hline & $\begin{array}{l}\text { Disposition Uranium } \\
\text { Complete disposition of } \\
\text { 1865 Metric Tons (MT) } \\
\text { of Hanford Uranium by } \\
\text { September 2000, }\end{array}$ & $\begin{array}{l}\text { Coordinating response to public comments on Environmental Assessment } \\
\text { (EA). Developed position paper on disposal of fuel elements in Low Level } \\
\text { Burial Ground (LLBG). Briefed HAB on intent to bury non-contaminated fuel } \\
\text { at LLBG. (Potentially saves \$1M over original baseline.) Continuing with } \\
\text { Phase I activities to prepare uranium billets, UO3 T-hoppers for shipment. } \\
\text { Will need additional funds in May to initiate Phase II and III or will not be } \\
\text { able to complete this work activity this year. Baseline change requests being } \\
\text { prepared. }\end{array}$ \\
\hline Multiple & $\begin{array}{l}\text { Comprehensive } \\
\text { performance }\end{array}$ & All baseline work projected to be complete per PI requirements. \\
\hline
\end{tabular}




\section{KEY INTEGRATION ACTIVITIES}

- Complete National Facility Deactivation Initiative (NFDI) DOE-complex implementation plan.

- $\quad 324$ Building B Cell project along with Spent Nuclear Fuel (SNF) developed an alternative plan for the fuel removal activity. SNF and DOE-RL are reviewing the options study to determine cost savings against the 200 Area Interim Storage life cycle costs.

- $\quad$ The DOE-HQ funded study of HLV Tank 105, located in the 324 Building is being conducted by AEA Technologies to demonstrate new technology in the deactivation of high dose radioactive tanks. The project technical plan, and implementation plan is completed while the draft of the alternatives assessment is on schedule for completion by April 2000.

- DOE-RL, Fluor Hanford, Inc., Bechtel Hanford, Inc. and Pacific Northwest National Laboratory participated in a 300 Area Accelerated Closure Plan briefing. The BCR was formally approved the week of March 20, 2000.

- NFDI is preparing to host multi-site joint National Facility Deactivation Initiative and Decommissioning \& Decontamination National Committee Meeting April 25 through 27, 2000 . 


\author{
S. H. Wisness, RL \\ Phone: (509) 373-9337 \\ D. S. Kelly, FH \\ Phone: (509) 376-7334
}




\section{SUMMARY}

The Landlord mission area consists of the Landlord Project, WBS 1.5.1, Project Baseline Summary (PBS) RL-TP13.

The demolition phase of Project L-270, "Emergency Services Renovation, 200 Area," completed on February 24, 2000. This demolition removed the $609 \mathrm{C}$ wing of the 200 Area Fire Station, which was required to make way for the construction of the new living quarters/administration addition (approximately 11,000 square feet).

Fiscal-year-to-date milestone performance (EA, DOE-HQ, Field Office, and RL) shows no milestones.

\section{ACCOMPLISHMENTS}

- Updated the 1100 Area Vacate Plan that focused primarily on identifying alternative locations to perform current and proposed warehousing activities and revising the costs associated with this potential relocation.

- Completed design on Project L-312, "2101M \& MO-235 Storm Draining Resolution."

\section{SAFETY}

FY 1999 performance was stable for case rates, but was very unstable in terms of severity (days away and restricted) with only one Lost Away case this fiscal year to date. This has had a negative impact on good FY 2000 performance with only one Lost Away case FYTD.

Safety Cost Index was previously set as Yellow due to the high fluctuation levels in the FY 1999 data. The baseline average is excellent, but was not predictable judging by one third of the FY 1999 data exceeded the UCL. However fiscal year to date experience is excellent and this indicator has been changed to green. 

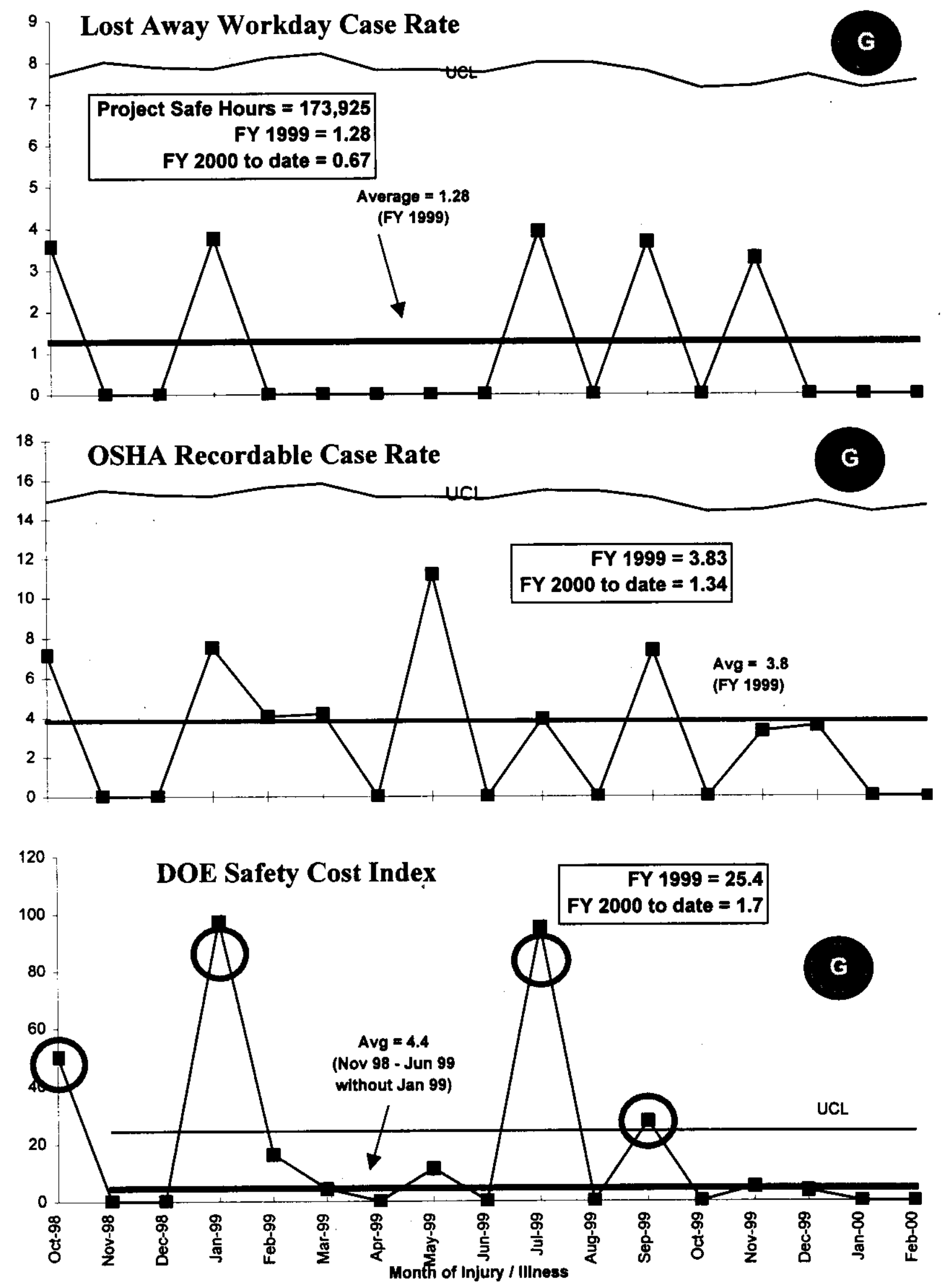


\section{ISMS STATUS}

- Continue to resolve the 16 concerns identified in DynCorp's ISMS Validation report. All 16 items are on schedule to be completed by July 1,2000 .

\section{BREAKTHROUGHS / OPPORTUNITIES FOR IMPROVEMENT}

\section{Breakthroughs}

- $\quad$ Nothing to report.

\section{Opportunities for Improvement}

- A new "fit-for-mission" philosophy that provides visibility and priority to Landlord Project budget requirements is required. This philosophy supports mission requirements as compared to past "run-to-failure" practices and aligns with current risk management practices and RL's three critical outcomes. 


\section{UPCOMING ACTIVITIES}

- On schedule to submit DynCorp's Voluntary Protection Program (VPP) application for Star Recognition by March 31, 2000.

- Preparatory work continues on flat car and well car characterization activities and on agreements for the transfer of flat cars to the Tri-Cities Asset Reinvestment Company through the Equipment Dispositioning Project (EDP).

\section{Cost Performance (\$M):}

\begin{tabular}{|l|c|c|c|}
\hline & BCWP & ACWP & VARIANCE \\
\hline Landlord & $\$ 4.2$ & $\$ 2.1$ & $\$ 2.1$ \\
\hline
\end{tabular}

The $\$ 2.1$ (50 percent) favorable cost variance is mainly attributed to the auction of six cranes for which a credit was received. Further information at the PBS level can be found in the following Cost Variance Analysis details.

\section{SChedule Performance (\$M):}

\begin{tabular}{|l|c|c|c|}
\hline & BCWP & BCWS & VARIANCE \\
\hline Landlord & $\$ 4.2$ & $\$ 5.0$ & $-\$ 0.8$ \\
\hline
\end{tabular}

The $\$ 0.8$ (16 percent) unfavorable schedule variance is attributed to funding reductions that impacted work scope related to Project L-314, Law Enforcement and Security Training Center. Renovations for water and restroom facilities will be deferred. Further information at the PBS level can be found in the following Schedule Variance Analysis details. 


\section{FY 2000 Cost/SChedule Performance - All Fund Types Cumulative to Date Status - (\$000)}

FYTD

By PBS

\begin{tabular}{llllllll}
\hline BCWS & BCWP & ACWP & SV & $\%$ & CV & $\%$ & PEM
\end{tabular}

WBS

1.5.1

TP13

$$
\begin{aligned}
& \text { Landlord } \\
& \$ 5,010 \\
& \begin{array}{lllll}
\$, 224 & \$ & 2,099 & \$
\end{array} \\
& \begin{array}{lllll}
(786) & -16 \% & \$ & 2,125 & 50 \%
\end{array}
\end{aligned}
$$

\begin{tabular}{|c|c|c|c|c|c|c|c|c|c|c|c|c|}
\hline FY2000 & OCT & NOV & DEC & JAN & FEE & TIKK & APR & RAY & JUN & JUL & AUE & SEP \\
\hline MONIALYSPI & 0.00 & 0.00 & 0.00 & 0.74 & 7.21 & & & & & & & \\
\hline MONIHLYCFT & 0,00 & 0.00 & 0.00 & -18.85 & 7.75 & & & & & & & \\
\hline FYTDSP & 0.00 & 0.00 & 0.00 & 0.74 & 0.84 & & & & & & & \\
\hline FYTDCPI & 0.00 & 0.00 & 0.00 & 2.15 & 2.01 & & & & & & & \\
\hline MONTALYBCWS & $\$ 0.0$ & खण & 30 & $\$ 3,934$ & $\$ 1,076$ & & & & & & & \\
\hline MONTHLY BCWP & 50.0 & 30 & $30-$ & $\$ 2,9222$ & $\$ 1,29 ;$ & & & & & & & \\
\hline MONIHLY ACWI & 3197.0 & 3549 & 5767 & (5155) & $\$ 742$ & & & & & & & \\
\hline FYTOECWS & $\$ 0.0$ & No.0 & $\$ 0.0$ & $5 \$ 3,934,0$ & $\$ 5,010.0$ & & & & & & & \\
\hline FYTDBCWP & 30.0 & 20.0 & 20.0 & $52,922,0$ & $3,2,2000$ & & & & & & & \\
\hline FYTOACWP & $\$ 197.0$ & $\$ 746.0$ & $\$ 1,513.0$ & $51,558.0$ & 32,10000 & & & & & & & \\
\hline
\end{tabular}

$\begin{array}{lllllll}(786) & -16 \% & \$ & 2,125 & 50 \% & \$ & 14,327\end{array}$

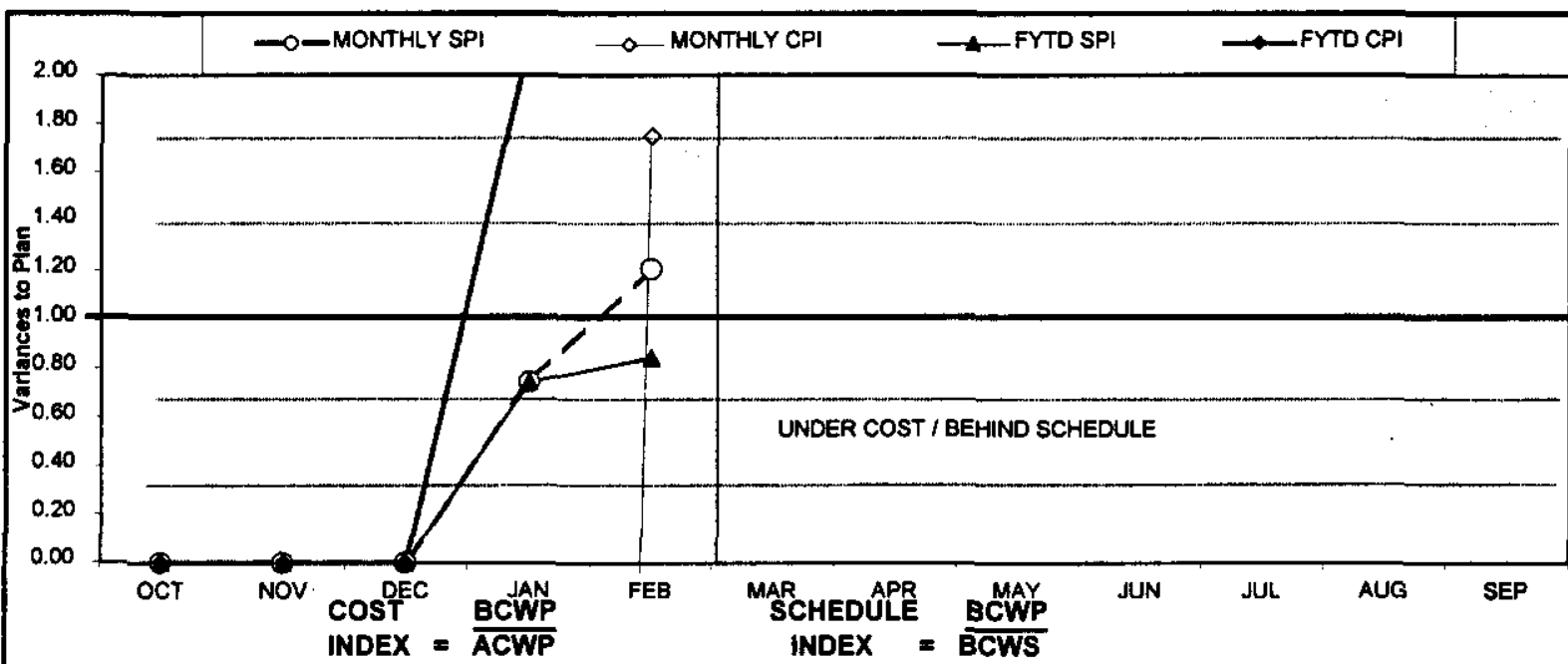




\section{Cost Variance Analysis: $(+\$ 2.1 M)$}

\section{$\underline{\text { WBS/PBS }} \quad \underline{\text { Title }}$}

\subsection{1/TP-13 Landlord}

Description/Cause: The favorable cost variance is mainly attributed to the auction of six cranes for which a credit was received. Procurement of one new crane is scheduled to be received next year (long lead procurement). In addition, the Municipal Planning Process and the Infrastructure Plan are underrunning. Also, line item budget from completed projects still in the baseline and reflecting a cost variance.

Impact: No impact to overall project and/or final cost.

Corrective Action: A requisition has been entered into Passport to procure the new crane, which replaces the six that were sold.

\section{Schedule Variance Analysis: ( $\$ 0.8 \mathrm{M})$}

\section{$\underline{\text { WBS/PBS }} \quad \underline{T i t l e}$}

\subsection{1/ WM03 Solid Waste Storage \& Disposal}

Description /Cause: The unfavorable schedule variance is attributed to funding reductions that impacted work scope related to Project L-314, Law Enforcement and Security Training Center. Renovations for water and restroom facilities will be deferred. In addition, two ambulances are behind the scheduled delivery date and will be received in April. The Municipal Planning Process and the Infrastructure Plan are behind schedule due to completion of other work scope. Furthermore, Landlord is working with RL to begin implementation of the Municipal Planning process. Several other projects had a late start due to the task order process.

Impact: Funding reductions require that scope be deferred for Project L-314 through a Baseline Change Request (BCR). Ambulances will be received in April. Other project delays are projected to be overcome with no overall impact to the project.

Corrective Action: A BCR will be implemented to address deferred workscope due to funding reductions and impacts for the rate changes.

\section{ISSUES}

There are no technical, DOE, Regulator or external issues identified at this time. 


\section{Baseline Change Requests Currently in Process (\$000)}

\begin{tabular}{|c|c|c|c|c|c|c|c|c|c|}
\hline $\begin{array}{l}\text { PROJECT } \\
\text { CHANCE } \\
\text { NUMBER }\end{array}$ & $\begin{array}{c}\text { DATE } \\
\text { ORIGIN. }\end{array}$ & BCR TITLE & $\begin{array}{l}\text { FY00 COST } \\
\text { IMPACT } \$ 000\end{array}$ & SCH & TECH & $\begin{array}{l}\text { DATE TO } \\
\text { CCB }\end{array}$ & $\begin{array}{c}\text { CCB } \\
\text { APR'VO }\end{array}$ & $\begin{array}{c}\mathbf{R L} \\
\text { APR'VD }\end{array}$ & $\begin{array}{l}\text { CURRENT } \\
\text { STATUS }\end{array}$ \\
\hline $\begin{array}{l}\text { LPM-00-001 } \\
\text { LPM-00-003 }\end{array}$ & $\begin{array}{l}11 / 3 / 99 \\
12 / 8 / 99\end{array}$ & $\begin{array}{l}\text { MYWP Baseline Modification } \\
\text { (Bridge BCR FY00, 01, 02) } \\
\text { Document FY99 Carryover Funds }\end{array}$ & $\begin{array}{l}\$ 4,642 \\
\$ 1,793\end{array}$ & $\mathrm{X}$ & $\begin{array}{l}X \\
X\end{array}$ & $\begin{array}{c}1 / 11 / 00 \\
12 / 13 / 00\end{array}$ & $\begin{array}{l}1 / 14 / 00 \\
1 / 3 / 00\end{array}$ & $\begin{array}{c}1 / 27 / 00 \\
1 / 3 / 00\end{array}$ & $\begin{array}{l}\text { Approved by } R L \\
\text { Approved by } R L\end{array}$ \\
\hline \multicolumn{10}{|c|}{ ADVANCE WORK AUTHORIZATIONS } \\
\hline & & Nothing to report & & & & & & & \\
\hline
\end{tabular}

\section{MILESTONE ACHIEVEMENT}

\begin{tabular}{|c|c|c|c|c|c|c|c|c|}
\hline \multirow[b]{2}{*}{ MILESTONE TYPE } & \multicolumn{2}{|c|}{ FISCAL YEAR-TO-DATE } & \multirow[b]{2}{*}{$\begin{array}{c}\text { Completed } \\
\text { Late }\end{array}$} & \multirow[b]{2}{*}{ Overdue } & \multicolumn{3}{|c|}{ REMAINING SCHEDULED } & \multirow[b]{2}{*}{$\begin{array}{l}\text { TOTAL } \\
\text { FY } 2000\end{array}$} \\
\hline & $\begin{array}{l}\text { Completed } \\
\text { Early }\end{array}$ & $\begin{array}{c}\text { Completed } \\
\text { On Schedule }\end{array}$ & & & $\begin{array}{c}\text { Forecast } \\
\text { Early }\end{array}$ & $\begin{array}{l}\text { Forecast } \\
\text { On } \\
\text { Schedule }\end{array}$ & $\begin{array}{c}\text { Forecast } \\
\text { Late }\end{array}$ & \\
\hline Enforceable Agreement & 0 & of & o & 0 & 0 & 0 & 0 & 0 \\
\hline DOE-HQ & $\overline{0}$ & 0 & 0 & 0 & $\overline{0}$ & 0 & 0 & 0 \\
\hline $\mathrm{RL}$ & 0 & 이 & 0 & 0 & 0 & 12 & 0 & 12 \\
\hline Total Project & 0 & 0 & 0 & 0 & 0 & 12 & 0 & 12 \\
\hline
\end{tabular}

\begin{tabular}{|l|l|}
\hline Nothing to report. & Tri-Party Agreement / EA Milestones \\
\hline Nothing to report. & DNFSB Commitments \\
\hline
\end{tabular}

MILESTONE EXCEPTION REPORT

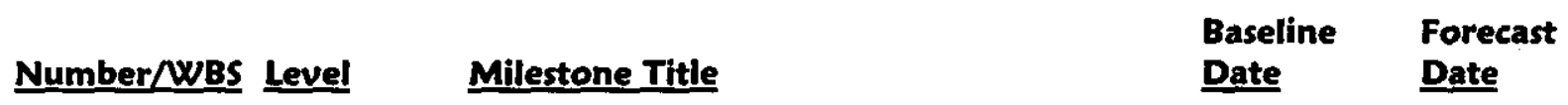

\section{OVERDUe - 0}

FORECAST LATE - 0 


\section{Performance Objectives}

The items listed below are not Performance Indicators. They are performance goals (i.e., milestones and goals incentivized by $\mathrm{FH}$ to the subcontractor).

\begin{tabular}{|c|c|c|}
\hline Outcome & Performance Goals & Status \\
\hline \multirow{7}{*}{$\begin{array}{l}\text { Restore the River } \\
\text { Corridor for } \\
\text { Multiple Uses } \\
\& \\
\text { Transition the } \\
\text { Central Plateau }\end{array}$} & $\begin{array}{l}\text { Replace } 1,500 \text { Feet of 2-inch Sanitary } \\
\text { Water Line from } 272 \mathrm{AW} \text { Building } \\
\text { Along Canton Ave. in the } 200 \text { East } \\
\text { Area }\end{array}$ & $\begin{array}{l}\text { Definitive design is approximately } 75 \% \text { complete and on } \\
\text { schedule to complete by April } 28,2000 \text {. The current status } \\
\text { supports construction completion on schedule by September } \\
29,2000 \text {. }\end{array}$ \\
\hline & $\begin{array}{l}\text { Provide Vegetation and Animal } \\
\text { Control to Reduce/Minimize the } \\
\text { Spread of Contamination }\end{array}$ & $\begin{array}{l}\text { Treated } 1,890 \text { acres fiscal year to date. Activities continue } \\
\text { as scheduled. }\end{array}$ \\
\hline & $\begin{array}{l}\text { Disposition } 38 \text { Abandoned Legacy } \\
\text { Non-Radioactive Waste Sites }\end{array}$ & Project remains on schedule. \\
\hline & $\begin{array}{l}\text { Complete Roof Replacement on South } \\
\text { Section of } 325 \text { Building }\end{array}$ & $\begin{array}{l}\text { Definitive Design is approximately } 90 \% \text { complete and is on } \\
\text { schedule to support completion of project construction by } \\
\text { September } 28,2000 \text {. }\end{array}$ \\
\hline & $\begin{array}{l}\text { Complete Installation of } 100 \mathrm{~K} / \mathrm{D} \\
\text { Emergency Notification Sirens which } \\
\text { will Complete the Total Integration of } \\
\text { All Outside Sirens }\end{array}$ & $\begin{array}{l}\text { Definitive Design for the retrofit of emergency sirens at } \\
100 \mathrm{~K} / \mathrm{D} \text { was completed on February } 17,2000 \text { as scheduled } \\
\text { and supports completion of the siren modification at } 100 \mathrm{~K} / \mathrm{D} \\
\text { by July } 28,2000 \text {. }\end{array}$ \\
\hline & $\begin{array}{l}\text { Complete Emergency Services } \\
\text { Renovation of the } 200 \text { Area Fire } \\
\text { Station }\end{array}$ & $\begin{array}{l}\text { Demolition of } 609 \mathrm{C} \text { was completed on February } 23,2000 \text {, } \\
\text { two months ahead of schedule. Construction completion of } \\
\text { the new Administration/Dormitory wing is approximately } \\
\text { one month ahead of the scheduled completion date of } \\
\text { April } 6,2001 \text {. }\end{array}$ \\
\hline & $\begin{array}{l}\text { Shutdown Approx. } 20 \text { Vacant Office } \\
\text { Facilities - Isolate } 25 \text { Vacant Facilities }\end{array}$ & $\begin{array}{l}8 \text { facilities have been shutdown for the fiscal year. } 13 \\
\text { facilities have been isolated. Project is on schedule. }\end{array}$ \\
\hline $\begin{array}{l}\text { Put Assets to } \\
\text { Work for the } \\
\text { Future }\end{array}$ & $\begin{array}{l}\text { Disposition One Well Car and One } \\
\text { Flat Car - Surveillance and } \\
\text { Maintenance of Legacy Rail Cars at } \\
\text { 212R Awaiting Disposition }\end{array}$ & $\begin{array}{l}\text { Detailed surveys of the flat cars continue as weather permits. } \\
\text { Preliminary investigation into an option to prepare the } \\
\text { Burlington Northern Santa Fe flat cars for free release at } \\
\text { Hanford was initiated. The National Environmental Policy } \\
\text { Act Categorical Exclusion review package was received by } \\
\text { DOE-RL and has started internal reviews. }\end{array}$ \\
\hline
\end{tabular}

\section{KEY INTEGRATION ACTIVITIES}

- Support Hanford Comprehensive Land Use Plan (CLUP). Record of Decision was issued in November 1999 which mandates that within the next 24 months Real Estate will be managed like a municipality.

- Continue to support development of the 300 Area Accelerated Closure planning project as required. Provided cost estimates for the development of a Utilities Plan and a Relocation Plan in support of the accelerated closure. 

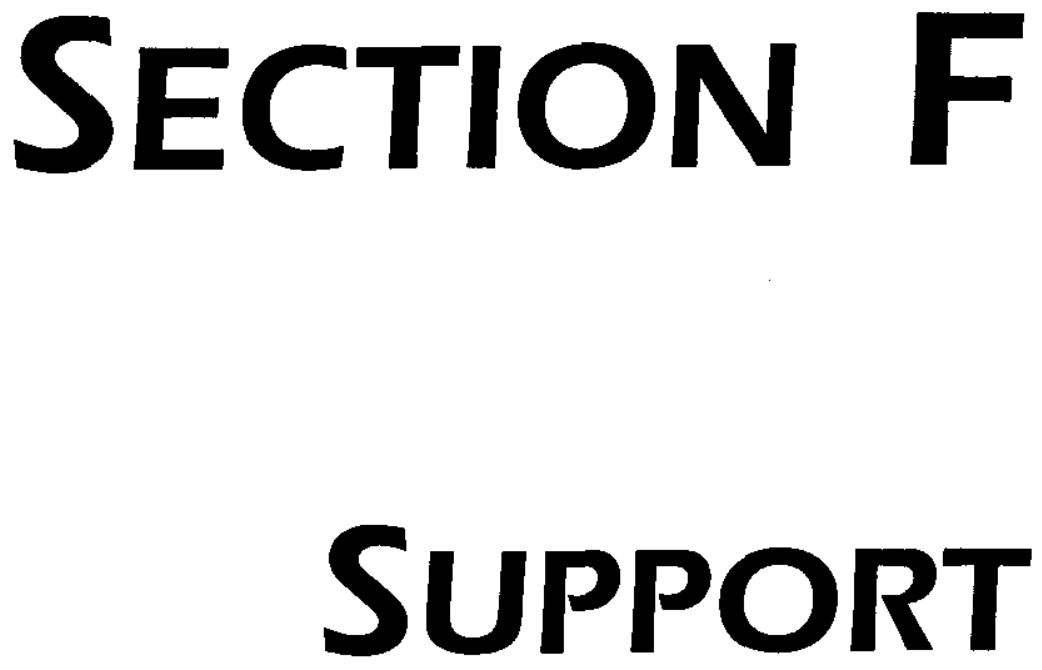

PROJECT MANAGERS

SP\&I W. W. Ballard, RL

G. J. McCleary, FH

SSE W. W. Ballard, RL

$$
\text { M. L. Grygiel, FH }
$$

ECP S. H. Wisness, RL

J. W. Hales, FH

PSRP S. H. Wisness, RL

R. L. Dirkes, PNNL
(509) 376-6657

(509) 372-8385

(509) 376-6657

(509) 372-2983

(509) 373-9337

(509) 376-4069

(509) 373-9337

(509) 376-8177 


\section{SUMMARY}

Mission Support, Project Baseline Summary (PBS) OT01, consists of four sub-projects:

- $\quad$ Planning and Integration (Work Breakdown Structure (WBS 1.8.2.1)

- $\quad$ Systems Engineering (WBS 1.8.2.2)

- $\quad$ Environmental Compliance (WBS 1.8.2.3)

The Environmental Compliance Program is composed of two elements. These two elements were stand-alone programs known as the Hanford Environmental Management Program (HEMP) and the Effluent and Environmental Monitoring Program (EEM) prior to FY99. Although there is a single program, these elements retain their identity on the Integrated Priority List as two separate Units of Analysis.

- $\quad$ Public Safety and Resource Protection (WBS 1.8.2.4)

In addition, Richland Directed Activities, PBS OT04, is included in this section. It consists of general site requirements such as :

- $\quad$ Resource Conservation and Recovery Act [RCRA] Mixed Waste Fee (management fee)

- Department of Health (DOH) Oversight (air monitoring)

- Downwinder Litigation

- Permits/site support [State of Washington (air emissions program)]

- $\quad$ Emergency Preparedness Grants

- State of Oregon Hanford Oversight

- $\quad$ Payment in Lieu of Taxes

- Hanford Advisory Board/Miscellaneous Grants (Hanford Openness Panel)

- Uranium Mass Balance Project (Paducah)

- $\quad$ National Security Analysis (formerly declassification of documents)

- As well as other minor financial assistances and contracts.

NOTE: Unless otherwise noted, the Safety, Conduct of Operations, and Cost/Schedule data contained herein is as of January 31, 2000. All other information is as of March 21, 2000.

Fiscal-year-to-date milestone performance (EA, DOE-HQ, FO, and RL) shows that 15 of 17 milestones ( 88 percent) were completed on or ahead of schedule, 1 milestone ( 6 percent) was completed late and 1 milestone (6 percent) is overdue. The Milestone Achievement details, found following cost and schedule variance analysis, provide further information on all milestone types.

\section{Site, Planning and Integration (SP\&I)}

Project Baseline Summary (PBS) Activities - SP\&I provided contractor training of the DOE-HQ Integrated Planning Accountability and Budget Information System (IPABS-IS) PBS module in February. Batch feeds of the baseline cost and performance data derived from Site baseline source systems were sent to DOE-HQ in late February. Results of the batch feeds to the 
IPABS-IS will provide the draft data necessary to meet the deliverable date of March 10, 2000.

The HQ IPABS database system has continued to present challenges for the Hanford users. Problems have included system availability, system overwrites, and failed batch feeds. Workarounds and additional inputs have resolved all current issues with the updates. The use of direct input or batch feeds may be evaluated in the May Lessons-Learned review.

Integrated Priority List (IPL) Activities - SP\&I assisted in coordinating and completing IPL updates reportable for FY 2002 - 2007. The updated IPL was formally submitted on February 25, 2000. The FH IPL included a 10 percent reduction to base operations (Essential Safety and Essential Services Units of Analyses) for FY 2001 and FY 2002 to cover priority shortfalls such as the PFP and B-Cell Cleanup. Subsequently, the FH project organizations were tasked with identifying the impacts and providing the results to SP\&I no later than March 9, 2000. This information will be briefed to FH Senior management for review and approval during March. Changes to the FY 2002 IPL may be made for the April submission to DOE-HQ.

Additionally, SP\&I continued identifying IPL module modifications in support of IPL requirements. New requirements have continued to surface as new strategies are developed for the presentation of the RL FY 2002 priorities to regulators and stakeholders.

PTS Replacement - Modifications to systems have been completed to support local data collection for the Environmental Management Performance Report (EMPR). These modifications provide the capability for non-PHMC contractors to input project performance data, and the ability to generate summary Environmental Management program reports. This information will be the source data for batch feeds to the Project Execution Module (PEM) of IPABS.

Training Support - A training/orientation session was provided to the Finance Division on the IPABS system. Module specific and general overview training was provided on the planning, budget, project execution, and reporting modules.

Indirect to Direct Conversion Activities - FH Senior management has recommended converting certain indirect activities associated with service pools and other specific activities to the direct program. Specifically, Site Services, Training, Safeguards and Security (SAS), and Information Resource Management (IRM) activities have been identified for conversion. Converting to a direct activity will provide the appropriate visibility for prioritization and life cycle planning that does not currently exist in the indirect program. Thus far, approval has been given to move the SAS activities for FY2001; all other moves are FY2002 actions and are presently pending approval. Implementing each move requires additional work to complete the FY 2002 Budget requests currently being prepared, and will also require the submittal of a Baseline Change Proposal (BCP) to DOE-HQ for approval.

SP\&I has supported the on-going Safeguards and Security (SAS) transfer to the Office of Security and Emergency Operations (SO)by coordinating efforts with Protection Technology 
Hanford (PTH) and the FH CFO to provide DOE-HQ requested SAS data. The conversion is driven by DOE-HQ direction and will become effective in FY 2001. Exact mechanisms for future budgeting have not yet been finalized by DOE-HQ; however, FH developed separate Units of Analyses for each affected Project Baseline Summary so that the conversion could be effected with minimal administrative impact to the FY 2002 Budget Formulation process.

Of significant concern is the impact of withdrawing the identified SAS amounts from each project. Analysis indicates that insufficient funding was budgeted to cover the amounts to be transferred. The principal reason for this shortfall is the application of a six-percent burden for SAS.

Modeling Tool Development - SP\&I continued work on developing a summary schedule product for use in assessing various EM work-scope priority scenarios. Status to generate a summary tool, utilizing detailed resource loaded project schedules, is provided to the Mission Planning Division weekly. SP\&I is working with other site contractors to incorporate their work-scope activities and project-to-project interfaces. This product is on schedule to be provided in the middle of May.

FYSF/EAC Review - SP\&I reviewed the projects' funding, budgets and cost trends. Fiscal Year Spend Forecasts (FYSF) were requested from the projects, and compared to the cost trends. Meetings were held within FH to review this information and determine whether funding was available to support Super Stretch initiatives. This process is being refined and formalized, and it is expected that these reviews will now be performed monthly.

Monthly Performance Management Meeting Revisions (MPMM) - Revisions to the monthly MPMMs continued in February and March for "The River" meeting held on March 9, 2000, and for "The Central Plateau" meeting held on March 10, 2000 and the PHMC Services/Comprehensive meeting on March 16. Significant changes were made to the format of the materials, as well as to the data therein. Efforts to accommodate suggested changes were coordinated with BHI and PNNL to assure a standardized, thorough presentation of such key information as Accomplishments, Issues, Cost/Schedule performance, and Performance Incentives performance. The above meetings were held as scheduled and were well received by RL.

EMPR Alignment with MPMM - During February, SP\&I initiated actions to better align the PHMC Environmental Management Performance Report (EMPR) with the material presented in the Monthly Performance Management Meetings (MPMMs). This effort included an evaluation and comparison of both data sets to determine suitability for the diverse and widespread EMPR audience and ultimate publication on the Internet. Once an initial determination was made, changes and additions to the existing EMPR content and format were included in updated guidance to the PHMC projects preparing sections of the report. It is expected that the report will continue to evolve over the next several months.

Business Management Oversight Process (BMOP) Status - FH received direction on February 23, 2000 to implement the revised business management performance expectations 
and measurement criteria. This is required per DOE 0 224.1, "Contractor Performance-Based Management Process," more commonly known as the Business Management Oversight Process (BMOP). FH management is currently reviewing the revised BMOP criteria to determine its alignment with the baseline and other existing vehicles for reporting results.

\section{Systems Integration (SI)}

Systems Integration provided support to the Chemical Management Program to determine if PassPort had the capabilities to manage chemical inventory data at Hanford; the River Corridor

Accelerated Deactivation efforts; the development of the Scorecard Metrics and the HQ PBS submittal. Systems Integration is developing the Interface Management Process (including known ICDs and MOUs) and Core Processes. Systems Integration also participated in an ISMS workshop and was involved in several key integration activities.

\section{Environmental Compliance Program (ECP)}

Nothing to report at this time.

\section{Public Safety and Resource Protection (PSRP)}

The PSRP Program Projects were all conducted in accordance with the scope, milestones, and budget defined in the FY 2000 PSRP Program (PBS \#RL-OT01) Multi-Year Work Plan during February.

\section{ACCOMPLISHMENTS}

- The Hanford Site Technical Database (HSTD) was used to identify Project work scope in the HQ submittal that is used as the basis for the congressional budget request (PBS update).

- Systems Engineering and Integration performed an analysis for FH Environmental Services to determine if the Hanford Site Chemical Management Procedure (HNF-PRO2258) had any unique requirements that were not referenced in other Hanford procedures. This analysis was performed to establish a basis to eliminate the procedure if no unique requirements were found.

- The 1999 Annual Dangerous Waste Report was transmitted to Ecology on March 1, 2000, meeting the due date stipulated in the Dangerous Waste Regulations (Milestone ECO-00-503).

- The final 1999 Hanford Site tier Two Emergency and hazardous Chemical Inventory was delivered, and the State Emergency Response Commission, Local Emergency Planning Committees, and Local Fire Departments on March 1, 2000 (Milestone ECP-00-501).

- Supported Ecology's ETF and TEDF Water Quality Inspection including three separate visits to ETF to review documents and support sampling. 
- Developed a revised Land Disposal Restriction (LDR) Resolution of Dispute.

- Developed, integrated, and transmitted comments to Ecology on WAC 173-303, Dangerous Waste Regulations.

- Performed facility reviews [Central Waste Complex (CWC), Low-Level Burial Grounds (LLBG), T-Plant \& 616-Building] of the regulatory file for NEPA coverage. Provided a new index of existing Categorical Exclusions in the file for T-Plant. This will enhance retrievability of the CX \& SWCS documents.

- Completed field and regulatory file assessments and compliance of CWC, LLBG, 616 Nonradioactive Dangerous Waste Storage Facility (NRDWSF), and T Plant.

- $\quad$ Prepared and Submitted the final DOE Order 435.1 gap analysis.

- The Environment \& Regulations web site has been published on the intranet (http://www.rl.gov/esh/hanford). Web page topics in gray identify future items under development. Additional information/pages continue to be developed along with maintaining minutes, documents, contact lists, etc.

- The Environmental Action Tracking System (EATS) Tally reporter has been developed to provide trend numbers by contractor, year, agency, and type of enforcement. Tally verification is currently underway. Once confidence in the tally numbers is achieved, the reporter will be added to the networked EATS Reporting Tool.

- Issued six Regulatory Analysis Memorandums at the request of $\mathrm{FH}$ projects.

- Milestone ECP-00-003, Biennial Assessment of Information/Data Access - M-035-09B, was completed on March 6, 2000, 25 days ahead of schedule.

- The winter ecological compliance baseline surveys within the 100 Areas (RL Milestone RLOT016005) were completed during the reporting period.

- Cultural Resources Project staff completed the Department of Interior Questionnaire (RL Milestone RLOT015006) and submitted it, thus fulfilling the February 15 due date. This questionnaire summarized all Hanford cultural resources activities in FY 1999.

- $\quad$ The post-hunting elk census was completed, recording a maximum count of 747 animals. Ecosystem Monitoring staff had worked with Washington Department of Fish and Wildlife staff and with U.S. Fish and Wildlife Service staff to plan the capture and transport of 200 elk from the Fitzner-Eberhardt Arid Lands Ecology Reserve, which was completed in early March.

Mission Support currently has no status to report in the areas of Safety, Conduct of Operations, Breakthroughs and Opportunities for Improvement. 


\section{ISMS STATUS}

Environment and Regulation and Environmental Services are continuing there efforts for readiness for Phase II Verification activities. Current activities include preparation of procedures and desk instructions for non-proceduralized activities, update of employee positions descriptions/training, documentation of lessons learned, and continued indoctrination of staff regarding ISMS principals and how these apply to the ECP work scope.

\section{UPCOMING ACTIVITIES}

- $\quad$ Annual Non-Radioactive Air Emissions to be completed by April 1, 2000.

- Annual Radionuclide Air Emissions to be completed by April 1, 2000.

- $\quad$ RCRA Permit Class 1 Mod Quarter to be completed by April 3, 2000.

- $\quad$ NEPA Activity Report to be completed by April 15, 2000.

- Issue Quarterly NESHAP Status Report to RL for EPA to be completed by April 21, 2000.

- Submit Revision of 91-28 to be completed by May 1, 2000.

- $\quad$ Provide RL with Air/Water Permitting Schedule to be completed by May 1, 2000.

\section{Cost Performance $(+2.6 \mathrm{M})$ :}

\begin{tabular}{|l|c|c|c|}
\hline & BCWP & ACWP & VARIANCE \\
\hline Mission Support 1.8.2 & $\$ 10.5$ & $\$ 8.0$ & $+\$ 2.6$ \\
\hline
\end{tabular}

The $\$ 2.6$ million (24 percent) favorable schedule variance is due to several factors. Further information at the PBS level can be found in the following Cost Variance Analysis details.

\section{SChedule Performance (\$-1.0M):}

\begin{tabular}{|l|c|c|c|}
\hline & BCWP & BCWS & VARIANCE \\
\hline Mission Support 1.8.2 & $\$ 10.5$ & $\$ 11.5$ & $-\$ 1.0$ \\
\hline
\end{tabular}

The $\$ 1.0$ million (nine percent) unfavorable schedule variance is within acceptable reporting thresholds. 
Fy 2000 COSt/SChedule Performance - All Fund Types Cumulative to Date Status - (\$000) FYTD

$\begin{array}{lllllllll}\text { By PBS } & \text { BCWS } & \text { BCWP } & \text { ACWP } & \text { SV } & \% & \text { CV } & \% & \text { PEM }\end{array}$

1.8.1 RL Directed

OT04 Support $\$ \quad \$ 6,477 \$ 5,064 \quad \$ \quad 6,025 \quad \$(1,413)-22 \% \$(961)-19 \% \$ 21,330$ Mission

1.8.2 Support Other

OT01 MYPs $\begin{array}{llllllllllll}\$ 11,520 & \$ 10,532 & \$ & 7,955 & \$ & (988) & -9 \% & \$ 2,577 & 24 \% & \$ 22,069\end{array}$

Total $\begin{array}{llllllllll}\$ 17,997 & \$ 15,596 & \$ 13,980 & \$(2,401) & -13 \% & \$ 1,616 & 10 \% & \$ 43,399\end{array}$

\section{COSt/SCHedule Performance Indices (FEBRUARY 2000 AND FYTD)}

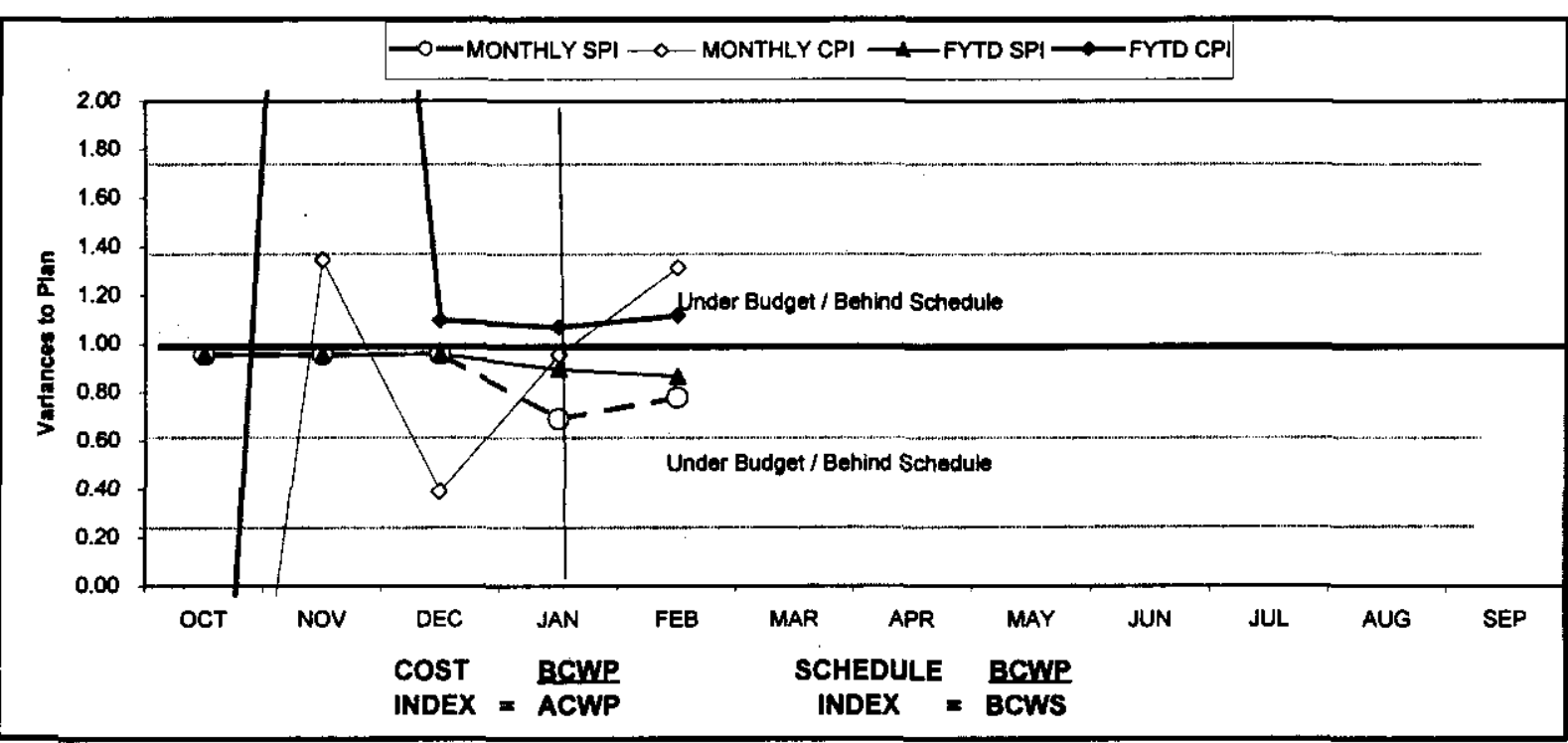

\begin{tabular}{|c|c|c|c|c|c|c|c|c|c|c|c|c|}
\hline FY 2000 & OCT & NOV & DEC & JAN & FEB & MAR & APR & MAY & JUN & JUL & AUG & SEP \\
\hline MONTHLY SPI & 0.96 & 0.96 & 0.96 & 0.69 & 0.78 & & & & & & & \\
\hline MONTHLY CPI & -2.25 & 1.34 & 0.39 & 0.95 & 1.31 & & & & & & & \\
\hline FYTD SP! & 0.98 & 0.96 & 0.96 & 0.90 & 0.87 & & & 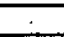 & & . & & \\
\hline FYTD CPI & -2.25 & 5.94 & 1.10 & 1.07 & 1.12 & & & & & & & \\
\hline MONTHLY BCWS & $\$ 3,493$ & $\$ 3,716$ & $\$ 3,221$ & $\$ 3,080$ & $\$ 4,487$ & & & & & & & \\
\hline MONTHLY BCWP & $\$ 3,339$ & $\$ 3,552$ & $\$ 3,087$ & $\$ 2,126$ & $\$ 3,492$ & & & & & & & \\
\hline MONTHLY ACWP & $(\$ 1,482)$ & $\$ 2,643$ & 57,932 & $\$ 2,227$ & $\$ 2,660$ & & & & & & & \\
\hline FYTD BCWS & $\$ 3,493$ & $\$ 7,209$ & $\$ 10,430$ & $\$ 13,510$ & $\$ 17,997$ & & & & & & & \\
\hline FYTD BCWP & $\$ 3,339$ & $\$ 6.891$ & 39,978 & $\$ 12,104$ & $\$ 15,586$ & & & & & & & \\
\hline FYTD ACWP & $(\$ 1,482)$ & $\$ 1,161$ & $\$ 9,093$ & $\$ 11,320$ & $\$ 13,980$ & & & & & & & \\
\hline
\end{tabular}

Nothing to report at this time. 


\section{COSt VARIANCE ANAlysis: (+2.6M)}

$\underline{\text { WBS/PBS }}$

\subsection{2/OT01}

$\$ 600 \mathrm{~K}$ of ECP February costs that were held is suspense due to an ECP funds (not budget) shortage.

PNNL has $\$ 130 \mathrm{~K}$ of unaccrued costs for analytical lab charges. A smaller portion of the variance is attributed to less than anticipated activity in some level-of-effort activities.

The remaining cost variance is due to understaffing in FH Systems Integration. The effects of new hiring in March should balance the variance by the end of the fiscal year.

Impact: No impact.

Corrective Action: No corrective action required.

\section{SCHEDULe VARIANCE ANALYSIS: $(-\$ 1.0 \mathrm{M})$}

\subsection{2/OT01}

\section{Mission Support}

The $\$ 1.0$ million (nine percent) unfavorable schedule variance is within acceptable reporting thresholds.

\section{Baseline Change Requests Currently in Process (\$000)}

\begin{tabular}{|c|c|c|c|c|c|c|c|c|c|}
\hline $\begin{array}{l}\text { PROJECT } \\
\text { CHANGE } \\
\text { NUMBER }\end{array}$ & $\begin{array}{c}\text { DATE } \\
\text { ORIGIN. }\end{array}$ & BCR TITLE & $\begin{array}{c}\text { FYOO COST } \\
\text { IMPACT } \$ 000\end{array}$ & SCH & TECH & $\begin{array}{c}\text { DATE } \\
\text { TO CCB }\end{array}$ & $\begin{array}{c}\text { CCB } \\
\text { APR'VD }\end{array}$ & $\begin{array}{c}\text { RL } \\
\text { APR'VD }\end{array}$ & $\begin{array}{l}\text { CURRENT } \\
\text { STATUS }\end{array}$ \\
\hline SPI-2000-002 & $10 / 22 / 99$ & FY 1999 Carryover Scope & $\$ 248$ & $\mathrm{X}$ & $\mathrm{X}$ & $2 / 3 / 00$ & $2 / 3 / 00$ & & In process \\
\hline & $2 / 17 / 00$ & $\begin{array}{l}\text { Modeling Tool \& IPL Module } \\
\text { Scope Additions FY } 2000\end{array}$ & $\$ 117$ & $\mathbf{x}$ & $\mathrm{x}$ & $2 / 17 / 00$ & $2 / 17 / 00$ & & In Process \\
\hline PSR-2000-001 & & $\begin{array}{l}\text { Alignment of Budget/Scope } \\
\text { to Funding Allocation and } \\
\text { Incorporation of FY } 1999 \\
\text { Carry Over }\end{array}$ & $\$ 193$ & $\mathrm{x}$ & & & & & \\
\hline PSR-2000-003 & & $\begin{array}{l}\text { Adjust project baseline to reflect } \\
\text { repricing changes to Basis of } \\
\text { Estimate, FY } 1999 \text { SAR } \\
\text { Implementation in FY } 2000 \text { and } \\
\text { incorporation of carry over. }\end{array}$ & $\$ 138$ & $\mathrm{X}$ & $\mathrm{x}$ & & & & \\
\hline \multicolumn{10}{|c|}{ ADVANCEWORK AUTHORIZATIONS } \\
\hline & & Nothing to report. & & & & & & & \\
\hline
\end{tabular}


Milestone ACHIEVEMENT

\begin{tabular}{|c|c|c|c|}
\hline \multicolumn{4}{|c|}{ 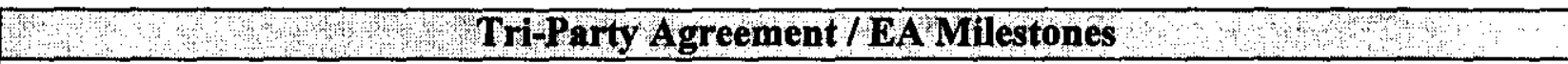 } \\
\hline Number & Milestone Title & Status & Complete \\
\hline ECP-00-302 & $\begin{array}{l}\text { RCRA Permit Class } 1 \text { Mod Notification } \\
\text { Quarter } 1 \text { (For Year 2000-2046) }\end{array}$ & $10 / 01 / 1999$ & $09 / 30 / 1999$ \\
\hline ECP-00-702 & $\begin{array}{l}\text { RCRA RPTS/DOCS Closure/Post Closure } \\
\text { Cost Est. to RL }\end{array}$ & $10 / 22 / 1999$ & 10/06/1999 \\
\hline ECP-00-901 & $\begin{array}{l}\text { Issue Quarterly NESHAP Status RPT to } \\
\text { RL for EPA }\end{array}$ & $10 / 22 / 1999$ & $10 / 20 / 1999$ \\
\hline EPC-00-306 & $\begin{array}{l}\text { Annual Asbestos Notification of Intent } \\
\text { (For Year 2000-2046) }\end{array}$ & $12 / 31 / 1999$ & $12 / 14 / 1998$ \\
\hline ECP-00-303 & $\begin{array}{l}\text { RCRA Permit Class } 1 \text { Mod Notification } \\
\text { Quarter } 2 \text { (For FY 2000-2046) }\end{array}$ & $01 / 01 / 2000$ & $12 / 16 / 1999$ \\
\hline ECP-00-902 & $\begin{array}{l}\text { Issue Quarterly NESHAP Status RPT } \\
\text { to RL for EPA }\end{array}$ & $01 / 22 / 2000$ & $01 / 17 / 2000$ \\
\hline ECP-00-410 & $\begin{array}{l}\text { Annual PTRAEU Report to DOE-RL } \\
\text { (For FY 200-2046) }\end{array}$ & $02 / 01 / 2000$ & overdue \\
\hline ECP-00-701 & Annual Noncompliance Report to RL & $02 / 24 / 2000$ & $02 / 09 / 2000$ \\
\hline ECP-00-503 & $\begin{array}{l}1999 \text { Hanford Site Annual Dangerous } \\
\text { Waste Report (FY 2000-2046) }\end{array}$ & $02 / 22 / 2000$ & $02 / 22 / 2000$ \\
\hline ECP-00-501 & $\begin{array}{l}\text { Tier II Emergency \& Hazardous } \\
\text { Chemical Inventory }\end{array}$ & $02 / 22 / 2000$ & $02 / 23 / 2000$ \\
\hline ECP-00-003 & $\begin{array}{l}\text { Biennial Assess. Of Info. \& Data } \\
\text { Access Needs EPA/ECO (2000-2046) }\end{array}$ & $03 / 31 / 2000$ & \\
\hline ECP-00-801 & $\begin{array}{l}\text { Transmit EIS/ODIS Data to INEEL } \\
\text { (FY 2000-2046) }\end{array}$ & $04 / 01 / 2000$ & \\
\hline ECP-00-802 & $\begin{array}{l}\text { Non-Radioactive Airborne Emissions } \\
\text { Report (FY 2000-2046) }\end{array}$ & $04 / 01 / 2000$ & \\
\hline ECP-00-304 & $\begin{array}{l}\text { RCRA Permit Class I Mod Notification } \\
\text { Quarter } 3 \text { (For FY 2000-2046) }\end{array}$ & $04 / 02 / 2000$ & \\
\hline ECP-00-904 & $\begin{array}{l}\text { Issue Quarterly NESHAP Status Report } \\
\text { To RL for EPA }\end{array}$ & $04 / 21 / 2000$ & \\
\hline ECP-00-803 & $\begin{array}{l}\text { Issue Annual Radionuclide Air Emissions } \\
\text { Report (For FY 2000-2046) }\end{array}$ & $06 / 15 / 2000$ & \\
\hline ECP-00-502 & $\begin{array}{l}\text { EPCRA Section } 313 \text { Toxic Chemical } \\
\text { Release Inventory }\end{array}$ & $06 / 24 / 2000$ & \\
\hline ECP-00-504 & Annual Document Log - June & $06 / 24 / 2000$ & \\
\hline ECP-00-305 & $\begin{array}{l}\text { RCRA Permit Class I Mod Notification } \\
\text { Quarter } 4 \text { (For FY 2000-2046) }\end{array}$ & $07 / 02 / 2000$ & \\
\hline
\end{tabular}




\begin{tabular}{|lll|}
\hline ECP-00-505 & PCB Annual Report - July & $07 / 08 / 2000$ \\
ECP-00-507 & Annual LDR Report (M-26-01) & $04 / 23 / 2000$ \\
ECP-00-906 & $\begin{array}{l}\text { Issue Quarterly NESHAP Status } \\
\text { Report to RL for EPA }\end{array}$ & $07 / 28 / 2000$ \\
ECP-00-703 & $\begin{array}{l}\text { Coordinate RCRA Pipe Mapping and } \\
\text { Marking (For FY 2000-2046) }\end{array}$ & $09 / 21 / 2000$ \\
ECP-00-301 & $\begin{array}{l}\text { RCRA General Facility Inspections } \\
\text { (For FY 2000-2046) }\end{array}$ & $09 / 30 / 2000$ \\
\hline
\end{tabular}

\section{MISSION SUPPORT - WBS 1.8 \\ MILESTONE ACHIEVEMENT}

\begin{tabular}{|c|c|c|c|c|c|c|c|c|}
\hline \multirow[b]{2}{*}{ MILESTONE TYPE } & \multicolumn{4}{|c|}{ FISCAL YEAR-TO-DATE } & \multicolumn{3}{|c|}{ REMAINING SCHEDULED } & \multirow[b]{2}{*}{$\begin{array}{c}\text { TOTAL } \\
\text { FY } \\
2000\end{array}$} \\
\hline & $\begin{array}{c}\text { Completed } \\
\text { Eanty }\end{array}$ & $\begin{array}{c}\text { Completed } \\
\text { On } \\
\text { Schedule }\end{array}$ & $\begin{array}{c}\text { Completed } \\
\text { Late }\end{array}$ & Overdue & $\begin{array}{c}\text { Forecast } \\
\text { Early }\end{array}$ & $\begin{array}{c}\text { Forecast } \\
\text { On } \\
\text { Schedule }\end{array}$ & $\begin{array}{c}\text { Forecast } \\
\text { Late }\end{array}$ & \\
\hline Enforceable Agreemen & 8 & 2 & 0 & 1 & 0 & 15 & 0 & 26 \\
\hline DOE-HQ & of & 0 & o & 0 & 0 & .2 & 0 & \\
\hline $\mathbf{R L}$ & उ| & 2 & T) & 0 & 0 & 177 & 0 & 23 \\
\hline Total Project & 11 & 4 & 1 & 1 & 0 & 34 & 0 & 51 \\
\hline
\end{tabular}

\section{MILESTONE EXCEPTION REPORT}

\section{Number/WBS Level \\ OVERDUE - 1}

Milestone Title

Baseline

Date

Forecast

Date

ECP-2000-410 HQ

\subsubsection{4}

Annual PTRAEU and HVU Report to RL $\quad 02 / 01 / 00 \quad 06 / 15 / 00$ Air and Water Services

Cause: The 02/01/00 milestone due date does not reflect the due date specified in the Technical Workscope Description for this activity. The 06/15/00 due date for this milestone in the Technical Workscope Description is the due date that DOE-RL is holding us accountable to. Impact: No impact.

Corrective Action: Change Request ECP-2000-004 has been submitted to change the date in CMM to $06 / 15 / 00$. Change Requested expected to be approved by $05 / 01 / 00$.

\section{Performance Objectives}

Nothing to report.

\section{KEY INTEGRATION ACTIVITIES}

Nothing to report. 

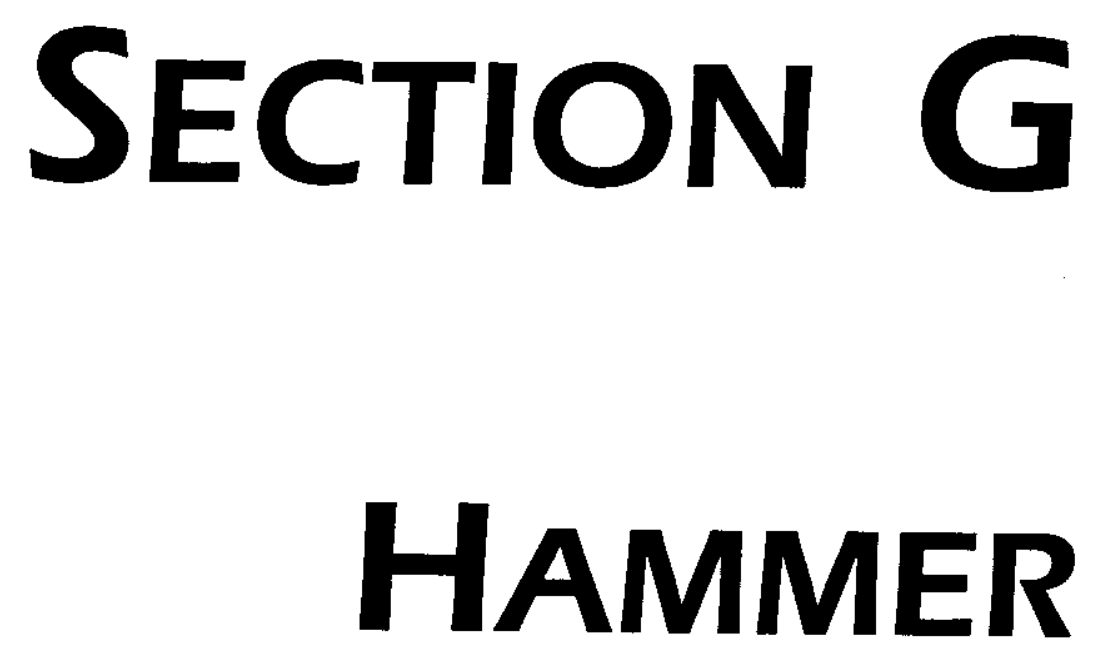

PROGRAM MANAGERS

\author{
J. E. Ollero, RL \\ Phone: (509) 376-3825
}

K. A. McGinnis, FH

Phone: (509) 376-9403 


\section{SUMMARY}

The Hazardous Materials Management and Emergency Response (HAMMER) mission area consists of the HAMMER project, WBS 1.9.1.1, Project Baseline Summary (PBS) HM01.

NOTE: Unless otherwise noted, the Safety, Conduct of Operations, and Cost/Schedule data contained herein is as of the end of February 2000. All other information is as of March 21, 2000 .

Volpentest HAMMER's first priority is to deliver hands-on training to the Hanford workforce. During February one hundred thirty-four classes were conducted at the Volpentest HAMMER facility, for a total of 1,877 Hanford site student days. Highest attended health and safety classes included Hazardous Waste Operations, Respiratory Protection, Radiation Worker II Requalification, Basic Medic First Aid and Fire Extinguisher Training. Overall satisfaction, rated on a scale of 1 to 5 based on level one evaluations, for the month of February: Course Content 4.52, Instructor(s) 4.65, and Facility 4.54.

A steering committee meeting was held during February in preparation for the Hanford Site field exercise, "Bold Endeavor". In addition, a tour was provided of the HAMMER facility on February 22 to view props which have been reserved for this site wide exercise.

The Volpentest HAMMER Training and Education center provided classrooms to the Emergency Preparedness organization to use as a control cell for the February 17, limited exercise called, "Rolling Thunder".

A special one-on-one session of the Building Warden Initial training (course \#037500) was presented at a moment's notice on February 24. This special class was presented in the EP Representative's office at the Federal Building to two Spent Nuclear Fuel (SNF) personnel who required this course immediately for a facility located near the container storage building (CSB) at 100 area.

The Environmental \& Waste Management (E\&WM) Product Line Manager (PLM) attended the Bonneville Power Administration (BPA) Managing Cultural Resources on the Columbia River Conference in Spokane. The E\&WM PLM met with the regional training manager of BPA who requested HAMMER to organize a combination of Archaeological Resources Protection Act (ARPA) Incident Investigation and Inadvertent Discovery of Human Remains class for the May time frame. The PLM was able to schedule with the provider, the Confederated Tribes of the Umatilla Indian Reservation's Cultural Resources Manager.

Non-DOE customers utilizing the Volpentest HAMMER facility for training activities, via the established HAMMER User Agreement process, included OSHA - Office of Training and Education and the Northwest Public Power Association. In addition three U. S. Army individuals from the Yakima Training Center received 24-hour Hazardous Waste Operations training. These training activities generated approximately $\$ 11,000$ of revenue for HAMMER. 
Generating revenue is included in the FY 2000 MYWP workscope activities for HAMMER, and will assist in reducing costs to DOE of providing site training.

Milestone performance (EA, DOE-HQ, and RL) shows that there are no milestones due fiscal year-to-date.

\section{ACCOMPLISHMENTS}

- Trained 1,877 Hanford site student days at HAMMER.

- Conducted steering committee meeting in preparation for the Hanford Site field exercise, "Bold Endeavor".

- Provided classrooms to support the Emergency Preparedness organization to use as a control cell for the February 17, limited exercise called, "Rolling Thunder".

- Conducted a special one-on-one session of the Building Warden Initial training (course $\# 037500$ ) on February 24.

- The E\&WM PLM attended the Bonneville Power Administration (BPA) Managing Cultural Resources on the Columbia River Conference in Spokane in support of the upcoming ARPA training activities.

- Two non-DOE customers utilized the Volpentest HAMMER facility for training activities. In addition three U. S. Army individuals from the Yakima Training Center received 24-hour Hazardous Waste Operations training.

HAMMER currently has no status to report in the areas of ISMS Status, Breakthroughs and Opportunities for Improvement.

\section{UPCOMING ACTIVITIES}

- $\quad$ OSHA Training Institute Class, Excavation, Trenching and Soil Mechanics March 28-31, 2000.

- The first FY 2000 Foreign Border Enforcement Training course will be presented to Moldova students April 25 - May 4, 2000.

- The second Foreign Border Enforcement Training course will be presented in June 2000.

- The Fire Operations Product Line will be developing programs that employ HAMMER props to train individuals who must meet new technical rescue standards. 
- The Fire Operations Product Line is working the U. S. Forest Service to establish training plans for fire fighters that rappel from helicopters. The rappelling course may involve construction of a new prop that could be used for other types of training - SWAT responders and military customers, for instance.

- $\quad$ HAMMER continues to work with the Criminal Justice Training Commission and Washington State Tactical Officer's Association to develop a Basic SWAT School to be held at HAMMER April 30 - May 5, 2000.

\section{Cost Performance $(\$ M):$}

\begin{tabular}{|l|c|c|c|}
\hline & BCWP & ACWP & VARIANCE \\
\hline HAMMER & $\$ 2.1$ & $\$ 2.1$ & $\$ 0.0$ \\
\hline
\end{tabular}

The cost variance is insignificant.

\section{SChedule Performance ( $\$ M):$}

\begin{tabular}{|l|c|c|c|}
\hline & BCWP & BCWS & VARIANCE \\
\hline HAMMER & $\$ 2.1$ & $\$ 2.1$ & $\$ 0.0$ \\
\hline
\end{tabular}

The schedule variance is insignificant.

\section{WBS 1.9}

FY 2000 COST/SCHEdule PerformanCe - All Fund TYPES Cumulative to Date Status - (\$000) FYTD

By PBS

$\begin{array}{lllllll}\text { BCWS BCWP ACWP SV } & \% & \text { CV } & \% & \text { PEM }\end{array}$

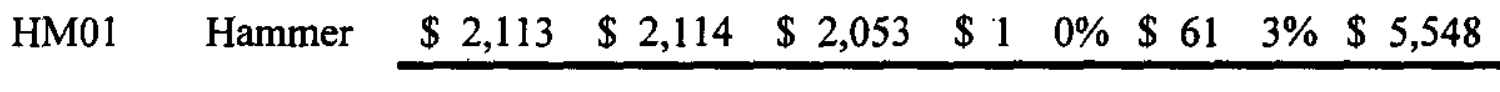

Total $\quad \begin{array}{lllllllllll}\$ 2,113 & \$ 2,114 & \$ 2,053 & \$ 1 & 0 \% & \$ 61 & 3 \% & \$ 5,548\end{array}$ 


\section{Cost/SChedule PerformanCe Indices (FEBRUARY 2000 AND FYTD)}

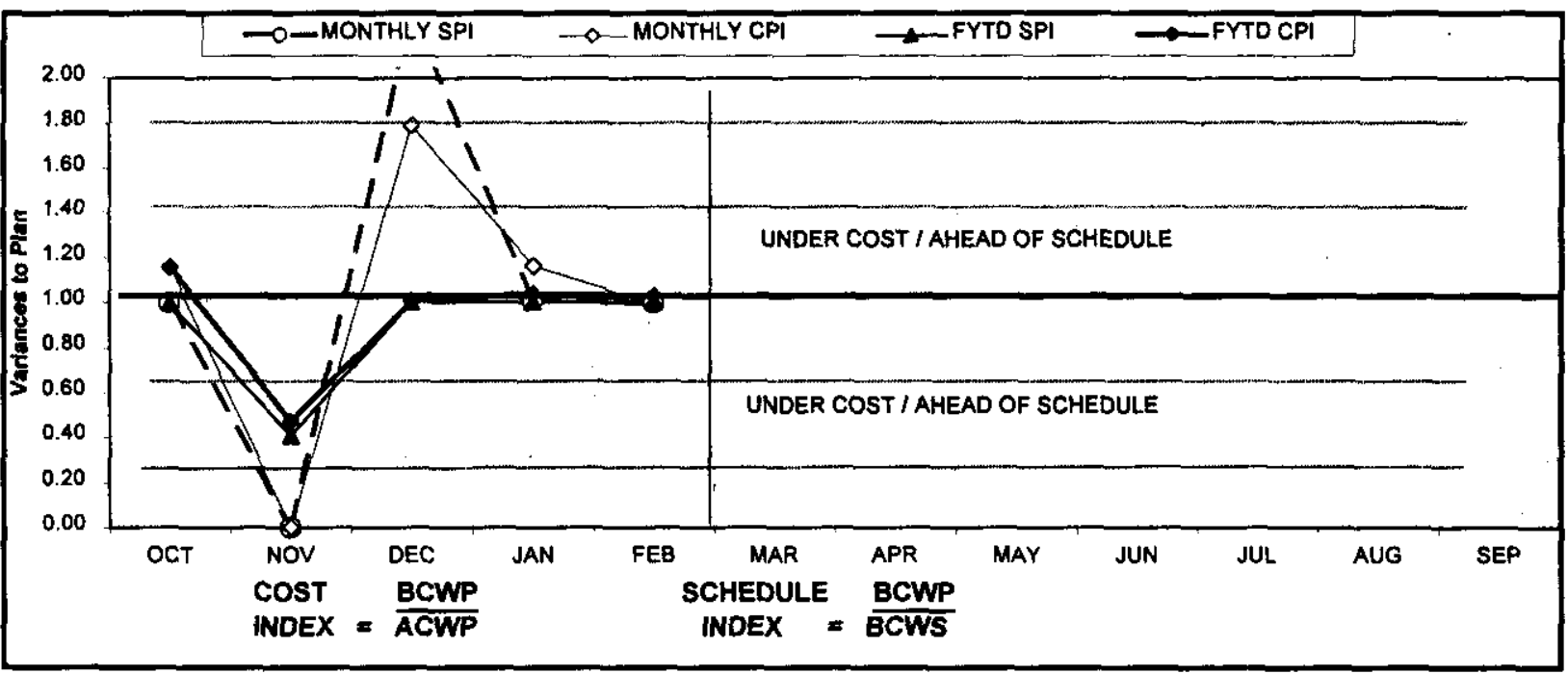

\begin{tabular}{|c|c|c|c|c|c|c|c|c|c|c|c|c|}
\hline FY2000 & OCT & Nor & DEC & JAN & Fas & MAR & APR & TAY & $\mathrm{JUK}$ & JUL & ADE & SEP \\
\hline MONTHLYSPI & 0.99 & 0.00 & 2.28 & 1.01 & 1.00 & & & & & & & \\
\hline MONIREYCPI & 7.16 & 0.00 & 7.79 & 1.16 & 0.99 & & & & & & & \\
\hline FYTDSP & 0.99 & 0.47 & 1.00 & 7.00 & $\pi .00$ & & & & & & & \\
\hline FYTOCPI & 1.16 & 0.47 & 7.01 & 1.04 & 1.03 & & & & & & & \\
\hline MONTHLY BCWS & 5352 & 507 & 395 & 418 & $\$ 10$ & & & & & & & \\
\hline MONIALY BCWI & 5350 & $5=$ & Suat & 422 & 736 & & & & & & & \\
\hline MONTHLYACWI & 5303 & 5439 & 505 & 363 & 443 & & & & & & & \\
\hline FYTDBCWS & $\$ 352$ & 5859 & 51,255 & 51,673 & 2,113 & & & & & & & \\
\hline FYTDBCWP & $\$ 350$ & 5350 & $\$ 1,254$ & 51,676 & 2,174 & & & & & & & \\
\hline FYTOACWP & $\$ 303$ & $\$ 742$ & 51,247 & 51,610 & 2,053 & & & & & & & \\
\hline
\end{tabular}

\section{COST VARIANCE ANALYSIS: $(\$ 0.0 \mathrm{M})$}

\section{WBS/PBS TITLE}

\subsubsection{1/HMO1 HAMMER}

Description and Cause: The variance is within thresholds.

Impact: None.

Corrective Action: None.

\section{SCHEDULE VARIANCE ANALYSIS: ( $\$ 0.0 \mathrm{M})$}

\section{WBS TITLE}

\subsubsection{1/HMO1 HAMMER}

Description and Cause: There is no variance.

Impact: None.

Corrective Action: None.

Nothing to report at this time.

\section{ISSUES}




\section{Baseline Chance Requests Currently in Process $(\$ 000)$}

\begin{tabular}{|l|c|c|c|c|c|c|c|c|c|}
\hline $\begin{array}{c}\text { PROJECT } \\
\text { CHANGE } \\
\text { NUMBER }\end{array}$ & $\begin{array}{c}\text { DATE } \\
\text { ORIGIN. }\end{array}$ & BCR TITLE & $\begin{array}{c}\text { FYOO COST } \\
\text { IMPACT SO00 }\end{array}$ & SCH & TECH & $\begin{array}{c}\text { DATE } \\
\text { TO CCB }\end{array}$ & $\begin{array}{c}\text { CCB } \\
\text { APR'VD }\end{array}$ & $\begin{array}{c}\text { RL } \\
\text { APR'VD }\end{array}$ & $\begin{array}{c}\text { CURRENT } \\
\text { STATUS }\end{array}$ \\
\hline & & Nothing to report. & & & & & & & \\
\hline \multicolumn{7}{|c|}{ ADVANCE WORK AUTHORIZATIONS } \\
\hline
\end{tabular}

\section{MILESTONE ACHIEVEMENT}

\begin{tabular}{|c|c|c|c|c|c|c|c|c|}
\hline \multirow[b]{2}{*}{ MILESTONE TYPE } & \multicolumn{4}{|c|}{ FISCAL YEAR-TO-DATE } & \multicolumn{3}{|c|}{ REMAINING SCHEDULED } & \multirow[b]{2}{*}{$\begin{array}{l}\text { TOTAL } \\
\text { FY } 2000\end{array}$} \\
\hline & $\begin{array}{l}\text { Completed } \\
\text { Early }\end{array}$ & $\begin{array}{l}\text { Completed } \\
\text { On Schedule }\end{array}$ & $\begin{array}{c}\text { Completed } \\
\text { Late }\end{array}$ & Overdue & $\begin{array}{c}\text { Forecast } \\
\text { Early }\end{array}$ & $\begin{array}{l}\text { Forecast On } \\
\text { Schedule }\end{array}$ & $\begin{array}{l}\text { Forecast } \\
\text { Late }\end{array}$ & \\
\hline Enforceable Agreement & 0 & $\overline{0}$ & 0 & 0 & 0 & 0 & & 0 \\
\hline DOE-HQ & 0 & $\overline{0}$ & 0 & $\overline{0}$ & 0 & $\overline{0}$ & & $\overline{0}$ \\
\hline$R L$ & 0 & $\overline{0}$ & 0 & 0 & 0 & 5 & & 5 \\
\hline Total Project & 0 & 0 & 0 & 0 & 0 & 5 & ( & 5 \\
\hline
\end{tabular}

\begin{tabular}{|l|}
\hline Tri-Party Agreement / EA Milestones \\
\hline Nothing to report. \\
\hline \\
\hline DNFSB Commitments \\
\hline Nothing to report. \\
\hline
\end{tabular}

\section{MiLESTONE EXCEPTION REPORT}

Number/WBS Level Milestone Title

Baseline

Forecast

OVerdue - 0

Date

Date

FORECAST LATE - 0 

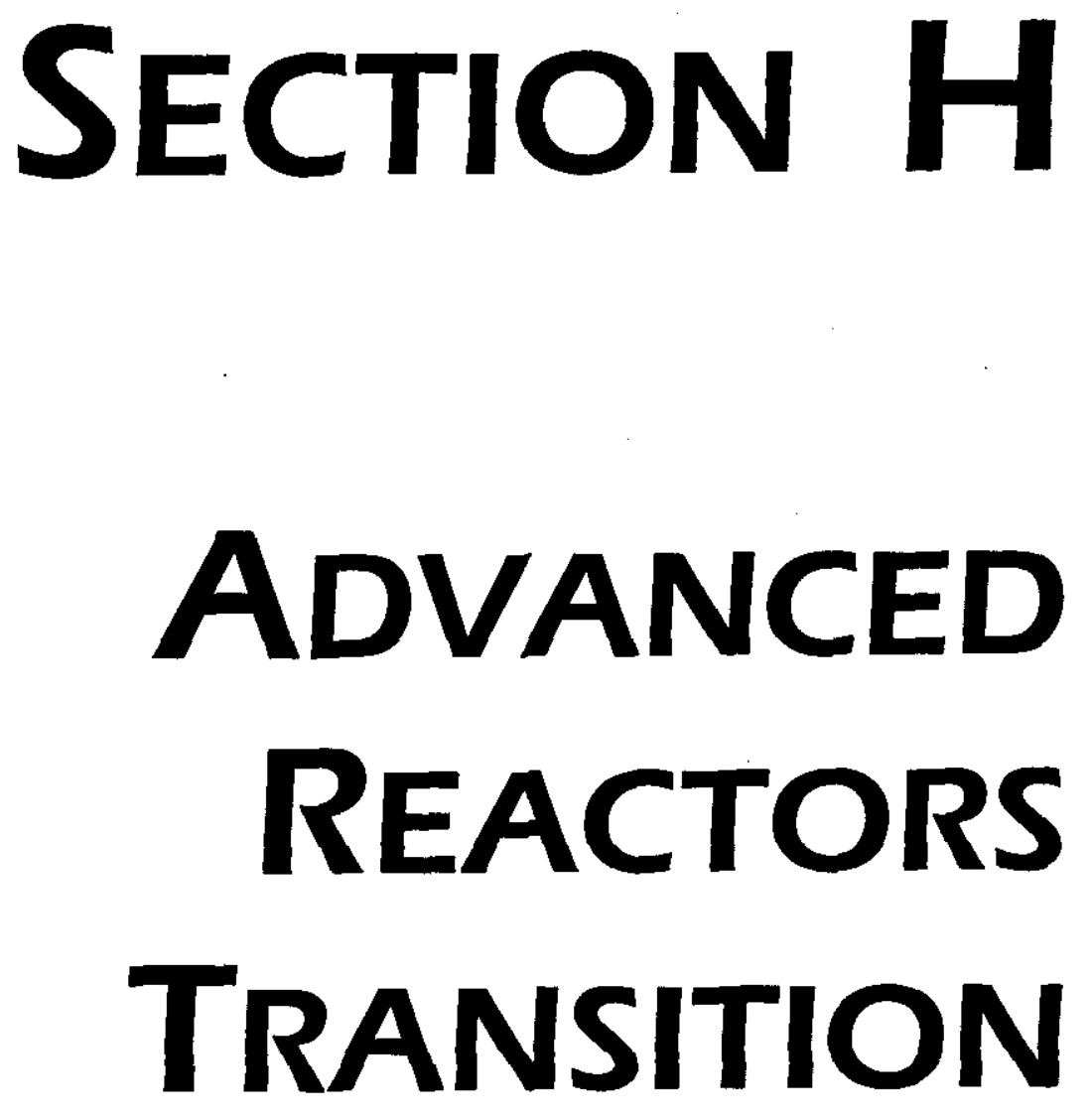

Project Managers

O. A. Farabee, RL

Phone: (509) 376-8089

\author{
D. B. Klos, FDH \\ Phone: (509) 373-3574
}




\section{SUMMARY}

The Advanced Reactors Transition (ART) Program, WBS 1.12.1.1, PBS RL-TP11, consists of the 309 Building and the Nuclear Energy (NE) Legacies activities

NOTE: Unless otherwise noted, the Safety, Conduct of Operations, and Cost/Schedule data contained herein is as of February 29, 2000. All other information is as of March 21, 2000.

Through March the ART mission area technical accomplishments included continued surveillance and maintenance activities on the 309 Building and NE Legacy facilities. The reaction phase of water vapor-nitrogen process for residual sodium in T plant tank TK-3 was completed. The rinsing and drying phase is underway. The conceptual plan for packaging the Thermal Transient Loop cold trap and shipping it off site was completed. The concept development for reacting residual $\mathrm{NaK}$ in the 337 cold trap cooling loop was initiated. This loop was drained of bulk $\mathrm{NaK}$ in 1998.

Fiscal-year-to-date milestone performance (EA, DOE-HQ, and RL) shows that there are no milestones due.

\section{ACCOMPLISHMENTS}

- Continued surveillance and maintenance activities on 309 Building and NE legacies.

- Completed reaction phase of water vapor-nitrogen process for residual sodium in $T$ plant tank TK-3. Rinsing and drying phase is underway.

- Developed conceptual plan for packaging the Thermal Transient Loop cold trap and shipping it off site.

- Began concept development for reacting residual $\mathrm{NaK}$ in the 337 cold trap cooling loop. This loop was drained of bulk $\mathrm{NaK}$ in 1998.

\section{SAFETY}

Specific safety data for ART is included in the statistics for the FFTF and RCP Projects.

\section{CONDUCT OF OPERATIONS / ISMS STATUS}

Specific Conduct of Operations information for ART is included in the FFTF and RCP Projects.

\section{ISMS STATUS}

The ISMS Internal Readiness Review progress included the Phase 1 portion to identify all implementing documents. 


\section{BREAKTHROUGHS / OPPORTUNITIES FOR IMPROVEMENT}

No breakthroughs or opportunities for improvement were identified at this time.

\section{UPCOMING ACTIVITIES}

Complete the rinsing and drying for cleaning of sodium residue from T Plant tank TK-3.

Initiate cleaning of the sodium potassium (Nak) residuals from the 337B Building cold trap cooling loop.

\section{Cost Performance $(\$ 0.1 \mathrm{M}):$}

\begin{tabular}{|l|c|c|c|}
\hline & BCWP & ACWP & VARIANCE \\
\hline Advanced Reactors Transition & $\$ 0.5$ & $\$ 0.5$ & $+\$ 0.0$ \\
\hline
\end{tabular}

There is no significant cost variance.

\section{SChedule Performance ( $\$ 0.0 \mathrm{M})$ :}

\begin{tabular}{|l|c|c|c|}
\hline & BCWP & BCWS & VARIANCE \\
\hline Advanced Reactors Transition & $\$ 0.5$ & $\$ 0.5$ & $+\$ 0.0$ \\
\hline
\end{tabular}

There is no significant schedule variance.

\section{FY 2000 Cost/SChedule Performance - All Fund Types Cumulative to Date Status - (\$000)}

By PBS

FYTD

\begin{tabular}{llllllll}
\hline BCWS & BCWP & ACWP & SV & $\%$ & CV & $\%$ & PEM
\end{tabular}

WBS 1.12 Advanced Reactors

\begin{tabular}{lllllllllllllll} 
TP11 Transition & $\$ 471$ & $\$$ & 483 & $\$ 461$ & $\$ 12$ & $3 \%$ & $\$$ & 22 & $5 \%$ & $\$ 1,454$ \\
\cline { 2 - 9 } & Total & $\$$ & 471 & $\$$ & 483 & $\$ 461$ & $\$ 12$ & $3 \%$ & $\$$ & 22 & $5 \%$ & $\$ 1,454$
\end{tabular}




\section{COST/SChedule PerformanCe Indices \\ (FEBRUARY 2000 AND FYTD)}

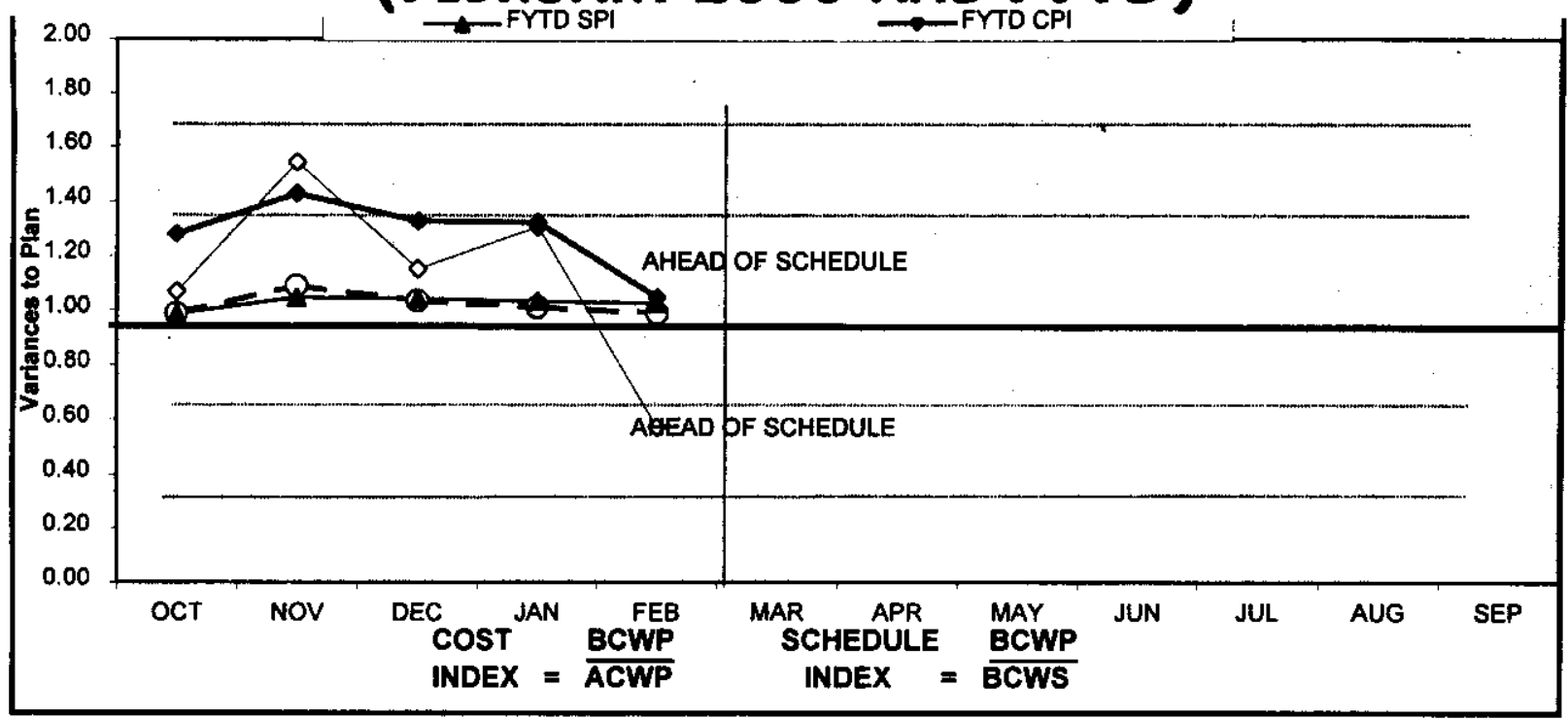

\begin{tabular}{|c|c|c|c|c|c|c|c|c|c|c|c|c|}
\hline FY20000 & OCT & NOV & DEC & JAN & FEB & MAR & APR & MAY & JUN & JUL & AUE & SEP \\
\hline MONTHLYSTI & 0.99 & 1.09 & 7.03 & 7.01 & 0.99 & & & & & & & \\
\hline MONTFLY CPI & 1.07 & 7.54 & 7.15 & 1.31 & 0.57 & & & & & & & \\
\hline FYTDSP & 0.99 & 7.05 & 1.04 & 7.03 & 1.03 & & & & & & & \\
\hline FYTDCP & 1.28 & 7.43 & 7.33 & 1.32 & 1.05 & & & & & & & \\
\hline MONTHLY BCWS & $\$ 79$ & $\$ 172$ & 589 & $\$ 93$ & $\$ 98$ & & & & & & & \\
\hline MONTHLY BCWP & $\$ 78$ & $\$ 122$ & $\$ 92$ & 594 & $\$ 97$ & & & & & & & \\
\hline MONTHLYACWP & $\$ 73$ & $\$ 79$ & $\$ 80$ & 572 & $\$ 169$ & & & & & & & \\
\hline FYTOBCWS & $\$ 79$ & $\$ 191$ & $\$ 280$ & $\$ 37 / 3$ & $\$ 47 T$ & & & & & & & \\
\hline FYTOBCWP & $\$ 78$ & $\$ 200$ & $\$ 292$ & $\$ 386$ & $\mathbf{5 4 8 3}$ & & & & & & & \\
\hline FYIDACWP & \$6T & $\$ 140$ & $\$ 220$ & $\$ 292$ & $\$ 467$ & & & & & & & \\
\hline
\end{tabular}

\section{COST VARIANCE ANALYSIS: $(+\$ 0.1 \mathrm{M})$}

\section{WBS/PBS Title}

\subsection{2/TP11 Advanced Reactors Transition}

Description and Cause: The favorable cost variance of $\$ 0.1 \mathrm{M}$ (25 percent) is due to no significant corrective maintenance activities being required.

Impact: None.

Corrective Action: None.

\section{SCHEDUle Variance ANALYsis: $(+\$ 0.0 \mathrm{M})$}

\section{$\underline{\text { WBS/PBS } \quad \text { Title }}$}

\subsection{2/TP11 \\ Advanced Reactors Transition}

Description and Cause: None.

Impact: None.

Corrective Action: None. 


\section{ISSUES}

Nothing to report at this time.

\section{Baseline Change Requests Currently in Process}

(\$000)

\begin{tabular}{|c|c|c|c|c|c|c|c|c|c|}
\hline $\begin{array}{l}\text { PROJECT } \\
\text { CHANGE } \\
\text { NUMBER }\end{array}$ & $\begin{array}{l}\text { DATE } \\
\text { ORIGIN. }\end{array}$ & BCR TITLE & $\begin{array}{l}\text { FY00 COST } \\
\text { IMPACT } \$ 000\end{array}$ & SCH & TECH & $\begin{array}{c}\text { DATE TO } \\
\text { CCB }\end{array}$ & $\begin{array}{c}\text { CCB } \\
\text { APR'VD }\end{array}$ & $\underset{\text { APR'VD }}{\mathbf{R L}}$ & $\begin{array}{l}\text { CURRENT } \\
\text { STATUS }\end{array}$ \\
\hline ART-2000-003 & $2 / 11 / 00$ & FY 1999 Carry Over Funds and Scope & 218 & $\mathbf{x}$ & $\mathbf{X}$ & $2 / 12 / 00$ & $2 / 17 / 00$ & $2 / 24 / 00$ & Approved \\
\hline \multicolumn{10}{|c|}{ ADVANCE WORK AUTHORIZATIONS } \\
\hline NE-001 & $2 / 16 / 00$ & 337 High Bay Cold Trap Cooling Loop & 35 & $\mathbf{X}$ & $\mathrm{X}$ & $2 / 17 / 00$ & $2 / 17 / 00$ & $2 / 23 / 00$ & Approved \\
\hline NE-002 & $2 / 16 / 00$ & $\begin{array}{l}\text { Transfer Waste (TW) Tank Farm } \\
\text { Ion Exchange Column }\end{array}$ & 35 & $\mathbf{X}$ & $\mathrm{X}$ & $2 / 17 / 00$ & $2 / 17 / 00$ & $2 / 23 / 00$ & Approved \\
\hline
\end{tabular}

\section{Milestone ACHIEVEMENT}

Fiscal-year-to-date milestone performance (EA, DOE-HQ, and RL) shows that there are no milestones due.

\begin{tabular}{|l|l|}
\hline & Trl-Party Agreement / EA Milestones \\
\hline Nothing to report & DNFSB Commitments \\
\hline & Nothing to report. \\
\hline
\end{tabular}

\section{MILESTONE EXCEPTION REPORT}

\begin{tabular}{|c|c|}
\hline 25 & $i+1$ \\
\hline
\end{tabular}

\section{OVERDUe - 0 \\ FORECAST LATE - 0}

\section{Performance Objectives}

Nothing to report.

\section{KEY INTEGRATION ACTIVITIES}

Nothing to report. 

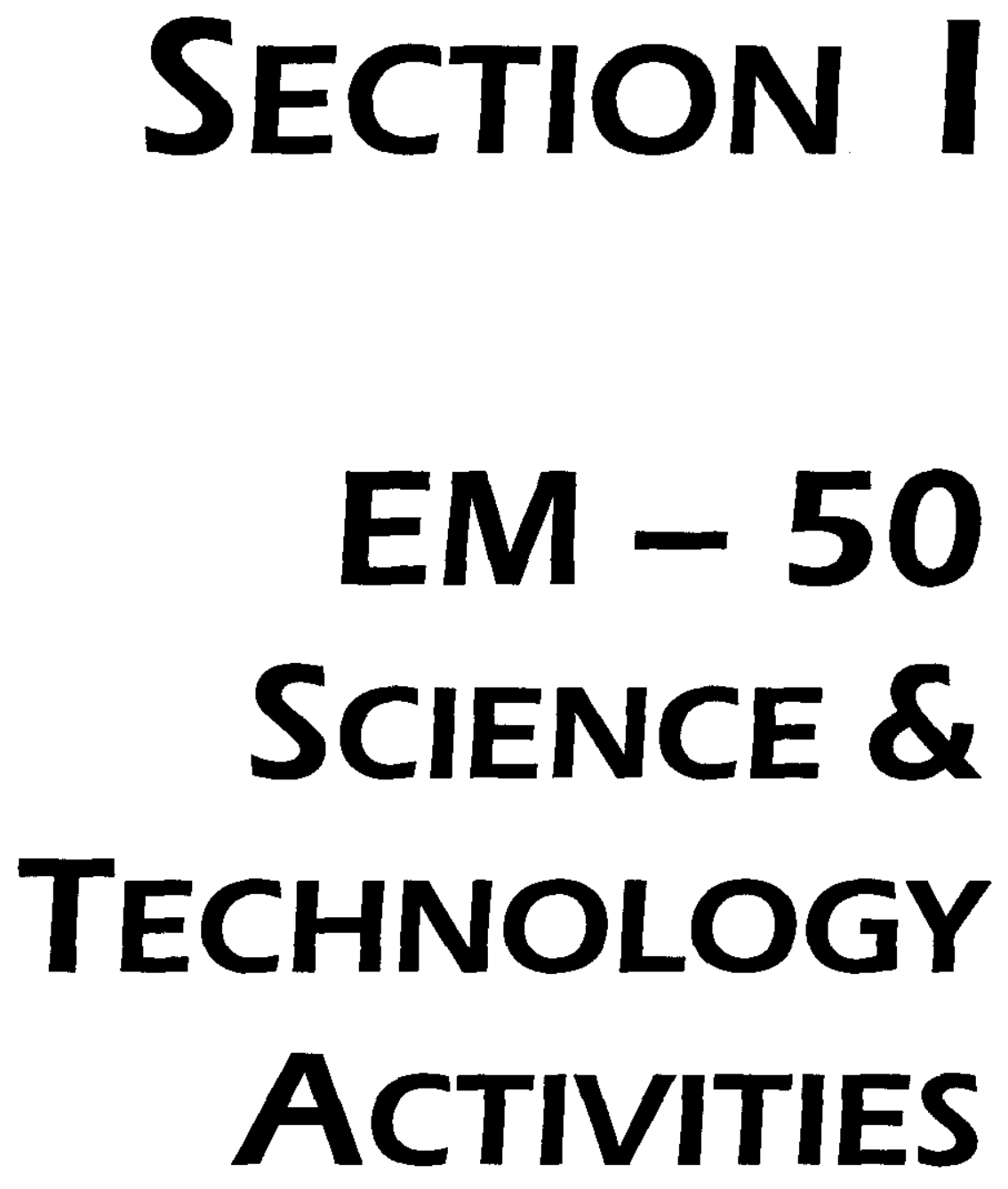


\section{EM-50}

\section{MILESTONE ACHIEVEMENT}

\begin{tabular}{|c|c|c|c|c|c|c|c|c|}
\hline \multirow[b]{2}{*}{ MILESTONE TYPE } & \multicolumn{4}{|c|}{ FISCAL YEAR-TO-DATE } & \multicolumn{3}{|c|}{ REMAINING SCHEDULED } & \multirow[b]{2}{*}{$\begin{array}{l}\text { TOTAL } \\
\text { FY } 2000\end{array}$} \\
\hline & Completed Early & $\begin{array}{c}\text { Completed On } \\
\text { Schedule }\end{array}$ & $\begin{array}{l}\text { Completed } \\
\text { Late }\end{array}$ & Overdue & $\begin{array}{l}\text { Forecast } \\
\text { Early }\end{array}$ & \begin{tabular}{|c|} 
Forecast \\
On. \\
Schedule
\end{tabular} & $\begin{array}{l}\text { Forecast } \\
\text { Late }\end{array}$ & \\
\hline Enforceable Agreement & 0 & 0 & $\overline{0}$ & $\overline{0}$ & $\overline{0}$ & 0 & 0 & \\
\hline DOE-HQ & 0 & 0 & 0 & 0 & 0 & 1 & 0 & \\
\hline RL & o & 0 & 1 & 2 & 0 & 1 & 0 & 4 \\
\hline Total Project & 0 & 0 & 1 & 2 & $\overline{0}$ & $\overline{2}$ & $\overline{0}$ & 5 \\
\hline
\end{tabular}




\section{EM-50 Exceptions}

$\begin{array}{lll}\text { Number Level Milestone Title } & \text { BASELNE } & \text { ForecAST } \\ \text { Date } & \underline{\text { Date }}\end{array}$

OVERDUe - 2

49MW21/C-2 RL Produce Report Mapping the Matrix Space 11/15/99 Proposed

2.1.1 (AMT) in Hanford Waste Boxes Deletion

Cause: Activities at WRAP were focused on preparing shipments to WIPP.

Impact: None

Corrective Action: Funding for this TTP was returned to the Mixed Waste Focus Area. This task is cancelled.

49MW21/B-4 RL Issue Software Test Reports

12/01/99 Proposed

2.1.1 (AMT) in Hanford Waste Boxes

Deletion

Cause: Activities at WRAP were focused on preparing shipments to WIPP.

Impact: None

Corrective Action: Funding for this TTP was returned to the Mixed Waste Focus Area. This task is cancelled. 

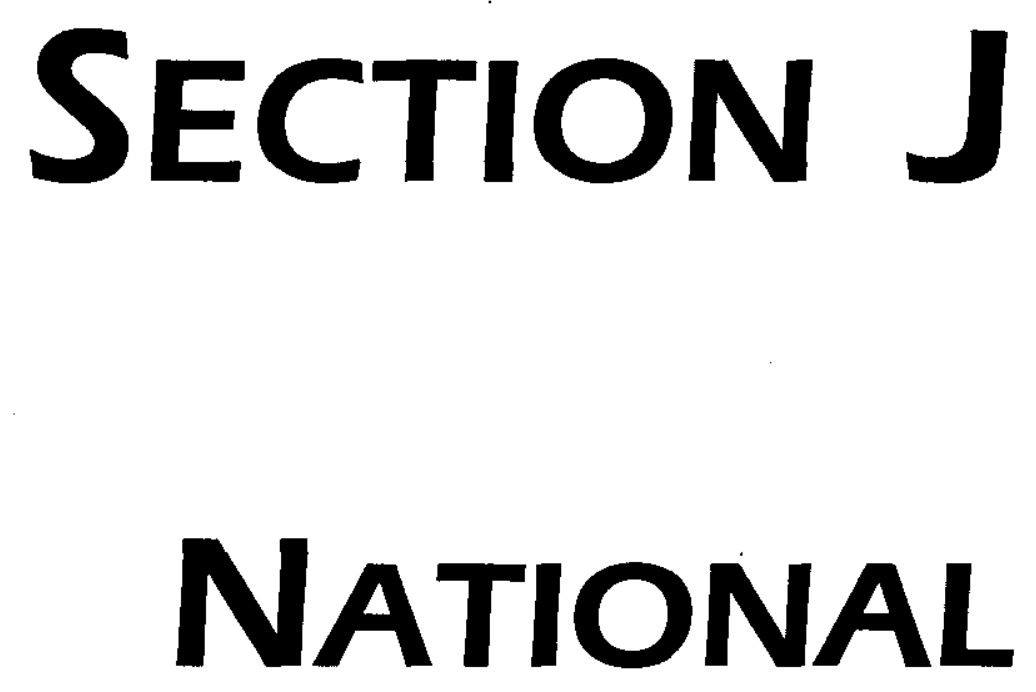

PROGRAMS 


\section{Introduction to National Programs}

DOE EM is responsible for a variety of National Programs. DOE-HQ typically provides operations policy and programmatic guidance to one or more field office that serve as lead for individual programs. FH currently supports the following National Programs: Transportation and Packaging (PBS OT02) and Pollution Prevention and Waste Minimization (PBS WM07).

Transportation and Packaging provides full-service transportation and packaging capabilities. Packaging services for radioactive and hazardous cargo is provided, including regulatory safetybasis documentation, certification, and licensing. Packaging plans and logistical studies for major shipping campaigns are also provided, as well as approved training courses in transportation safety and waste management. Transportation and traffic logistics management, engineering and operational support to offsite customers, carrier selection and evaluation, automated transportation management systems used by the U.S. Department of Energy (DOE) complex and commercial vendors, and international transport of hazardous and radioactive packages are other services provided.

Pollution Prevention and Waste Minimization (P2/WMin) coordinates the development and implementation of a Hanford Site P2/WMin Program to comply with Federal, state, and DOE directives. The program's purpose is to achieve Site objectives through effective and efficient methodologies tailored to generator activities and operations.

\section{FY 2000 Cost/Schedule Performance - All Fund Types Cumulative to Date Status - (\$000)}

By PBS

WBS 1.11 Transportation \&

OT02 Packaging (RL 7601)

Packaging (RL 7601)

WM07 (RLHQ 7770)

Total

\section{FYTD}

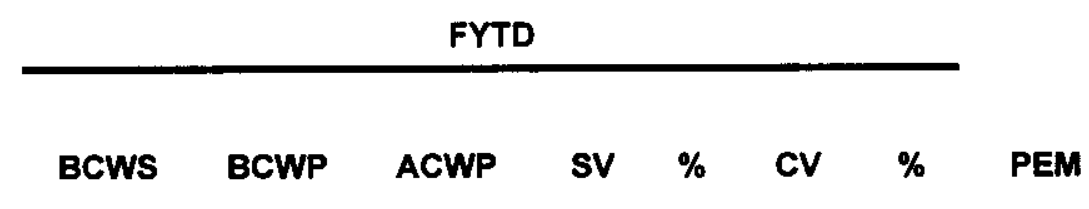

$\begin{array}{llllllllllllll}\$ & 805 & \$ & 805 & \$ & 654 & \$ & - & 0 \% & \$ & 151 & 19 \% & \$ & 1,972\end{array}$

\begin{tabular}{lllllllllllll}
$\$$ & 864 & $\$$ & 864 & $\$$ & 628 & $\$-$ & $0 \%$ & $\$ 236$ & $27 \%$ & $\$$ & 3,801 \\
\hline
\end{tabular}

$\begin{array}{lllllllllll}\$ 1,669 & \$ 1,669 & \$ 1,282 & \$ & - & 0 \% & \$ 387 & 23 \% & \$ 5 & 5,773\end{array}$ 


\section{Cost/Schedule Performance Indices (FEBRUARY 2000 AND FYTD)}

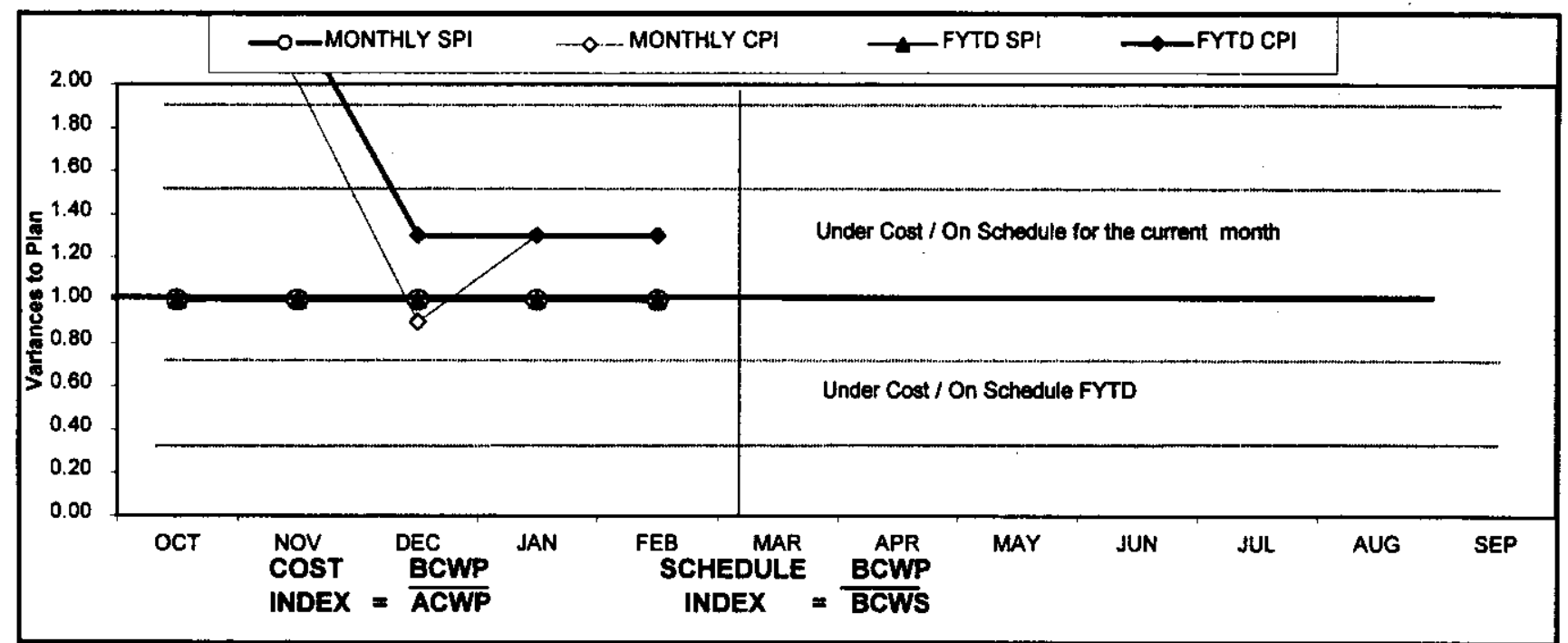

\begin{tabular}{|c|c|c|c|c|c|c|c|c|c|c|c|c|}
\hline FYZOOOO & OCT & NOV & DEC & JAN & FEB & MAR & APR & TIAY & JUN & JUL & AUS & SEP \\
\hline MONTHLYSPT & 1.00 & 1.00 & 7.00 & 1.00 & 1.00 & & & & & & & \\
\hline MONIHLYCPI & 2.81 & 2.01 & 0.90 & 1.30 & 1.30 & & & & & & & \\
\hline FYTDSPT & 1.00 & 1.00 & 7.00 & 1.001 & 1.00 & & & & & & & \\
\hline FYTOCFI & 2.81 & 2.30 & 7.30 & 1.301 & 7.30 & & & & & & & \\
\hline MONTHLY BCWS & 3304 & 5383 & 5658 & $\$ \$ 24$ & $\$ 324$ & & & & & & & \\
\hline MONTRLY BCWP & $\$ 3104$ & 5383 & $\$ 658$ & $\$ 324$ & 3324 & & & & & & & \\
\hline MONIRLY ACWP & 5108 & इ191 & $\$ 7 / 34$ & $\$ 249$ & $\$ 249$ & & & & & & & \\
\hline FYTDBCWS & 3304 & $\$ 687$ & $\$ 1,015$ & $\$ 1,345$ & $\$ 1,669$ & & & & & & & \\
\hline FYTDECWP & 5304 & $\$ 687$ & $\$ 1,015$ & $\$ 1,345$ & $\$ 1,669$ & & & & & & & \\
\hline FYTDACWP & $\$ 108$ & $\$ 299$ & 3521 & $\$ 1,033$ & $\$ 1,282$ & & & & & & & \\
\hline
\end{tabular}

\section{Cost Variance Analysis: $(+\$ 0.4)$}

WBS/PBS

Title

The favorable cost variance is within the established threshold.

\section{Schedule Variance Analysis: $\mathbf{( \$ 0 . 0 )}$}

\section{$\underline{\text { WBS/PBS }} \quad \underline{\text { Title }}$}

There is no schedule variance. 


\section{Richland Operations Office Environmental Restoration Environmental Management Performance Report}

\section{April 2000}

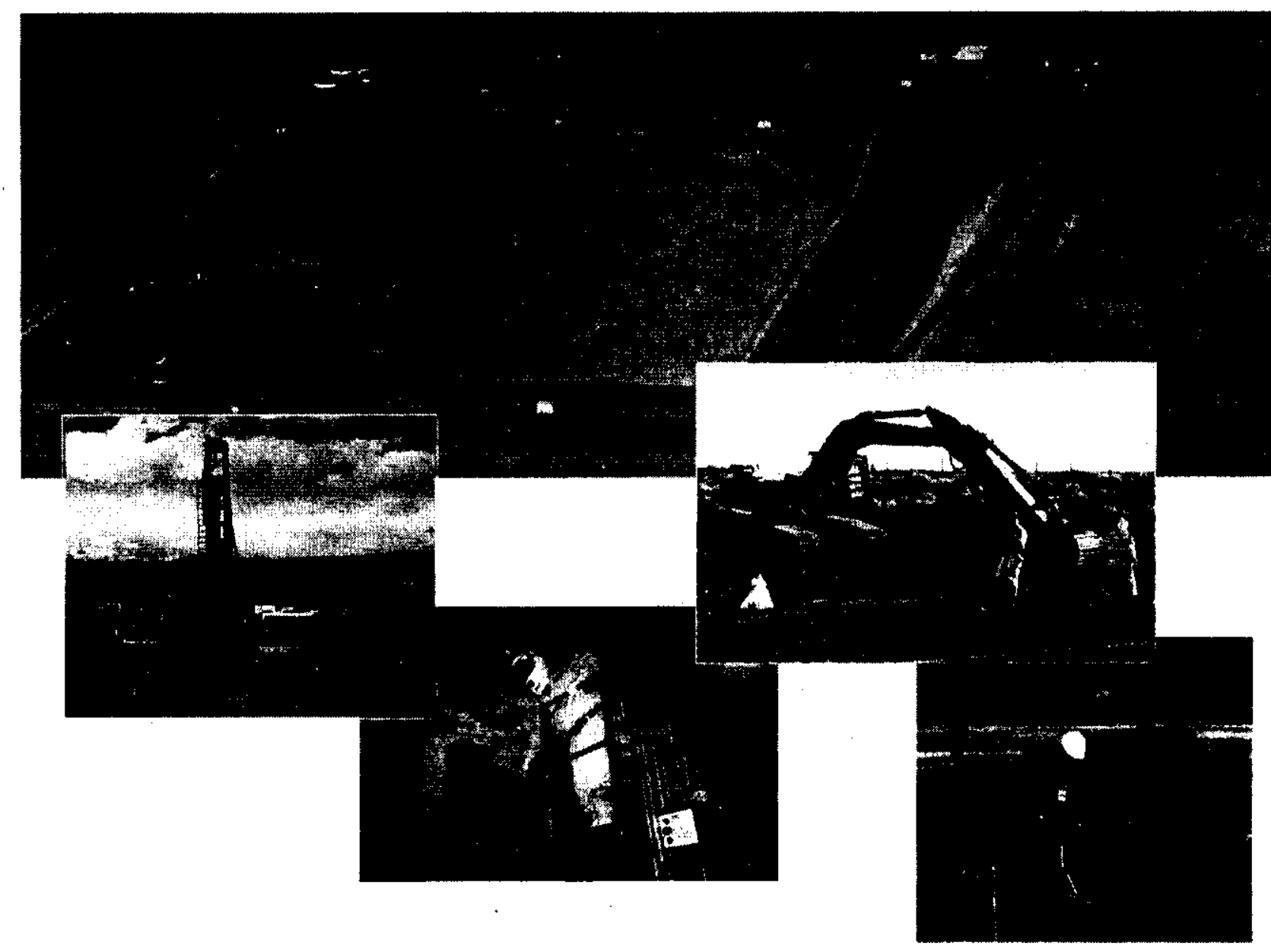

Focused on Progress...

Focused on Outcomes!

Department of Energy Richland Operations Office

M

.

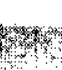




\section{TABLE OF CONTENTS}

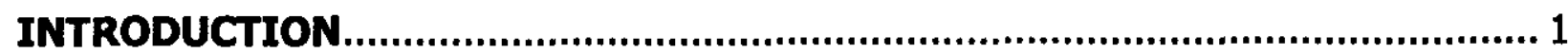

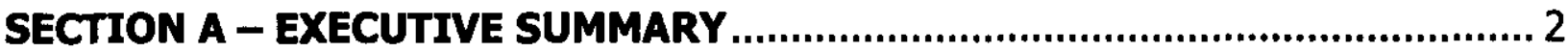

NOTABLE ACCOMPLISHMENTS .................................................................... 3

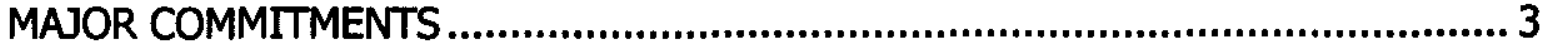

SAFETY/ISMS/CONDUCT OF OPERATIONS …............................................... 5

REGULATORY/EXTERNAL/DOE-RL \& HQ ISSUES AND REQUESTS ....................... 7

TOTAL COST/SCHEDULE OVERVIEW ............................................................ 10

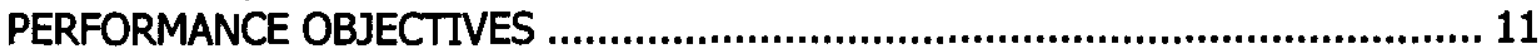

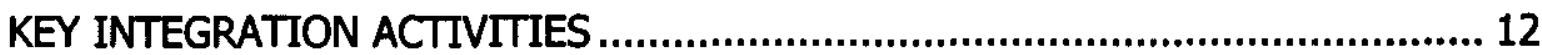

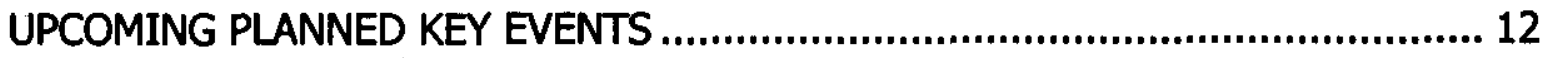

SECTION B - RESTORING THE RIVER CORRIDOR PROJECT SUMMARIES..... 13

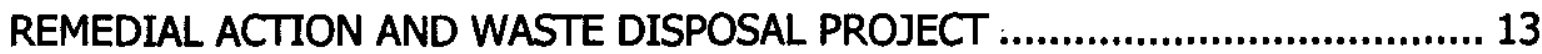

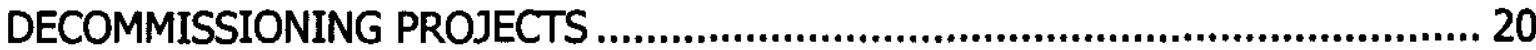

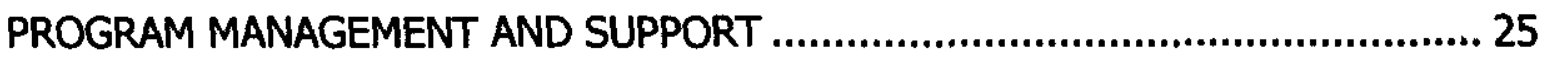

SECTION C - TRANSITIONING THE CENTRAL PLATEAU PROJECT

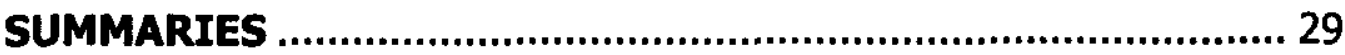

GROUNDWATER/VADOSE ZONE INTEGRATION PROJECT ....................................2 29

SURVEILLANCE/MAINTENANCE AND TRANSITION PROJECTS............................. 37 


\section{ENVIRONMENTAL MANAGEMENT PERFORMANCE REPORT ENVIRONMENTAL RESTORATION \\ APRIL 2000}

\section{INTRODUCTION}

The monthly Environmental Restoration (ER) Environmental Management Performance Report consists of three sections: Section A - Executive Summary, Section B - Restoring the River Corridor Project Summaries, and Section C Transitioning the Central Plateau Project Summaries.

Section A - Executive Summary. This section provides an executive level summary of Bechtel Hanford, Inc.'s (BHI) performance information for the current reporting month and is intended to bring to Management's attention that information considered to be most noteworthy. The Executive Summary begins with a description of notable accomplishments that are considered to have made the greatest contribution toward safe, timely, and cost-effective cleanup. Major commitments are summarized that encompass Hanford Federal Facility Agreement and Consent Order (Tri-Party Agreement) milestones and FYOO Management Commitment milestones. Safety statistics are also included. Issues that require management and/or regulator attention and resolution status are addressed. Fiscal year-to-date ERC Project cost and schedule variance analysis is summarized. The Key Integration Activities section highlights site activities that cross contractor boundaries and demonstrates the shared value of working as a team to accomplish the work. The Executive Summary ends with a listing of major upcoming planned key events within a 90-day period.

Section B - Restoring the River Corridor. This section contains more detailed monthly activity information and performance status for the three projects within the 'Restoring the River Corridor' outcome. These three projects consist of the Remedial Action and Waste Disposal Project, Decommissioning Projects, and the Program Management and Support (PM\&S) Project.

Section C - Transitioning the Central Plateau. This section contains more detailed monthly activity information and performance status for the two projects within the 'Transitioning the Central Plateau' outcome. These two projects consist of the Groundwater/Vadose Zone (GW/VZ) Integration Project and the Surveillance/Maintenance and Transition (SM\&T) Projects.

Information in this report is identified with a green, yellow, or red text box used as an indicator of the overall status. Green indicates work or issue resolution is satisfactory and generally meets or exceeds requirements; yellow indicates that significant improvement is required; and red indicates unsatisfactory conditions requiring immediate corrective actions. 
ENVIRONMENTAL MANAGEMENT PERFORMANCE REPORT ENVIRONMENTAL RESTORATION

APRIL 2000

\section{Section A: \\ Executive Summary}




\section{ENVIRONMENTAL MANAGEMENT PERFORMANCE REPORT ENVIRONMENTAL RESTORATION \\ APRIL 2000}

\section{SECTION A - EXECUTIVE SUMMARY}

Financial data as of month-end February. All other data as of March 23, unless otherwise noted.

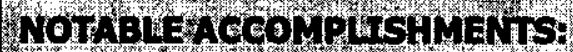

Excavation of waste sites at 100-D, 100-H, and 300 Area in progress. Backfill activities were completed at 12 small waste sites (Group 3) in the $100 \mathrm{~B} / \mathrm{C}$ Area in February. This backfill completion will satisfy Hanford

Federal Facility Agreement and Consent Order (Tri-Party Agreement) Milestone M-16-08B.

A/I F Reactor ISS demolition was completed except for the fuel storage basin.

The $F$ and DR Reactor safe storage enclosure (SSE) concrete contract was awarded.

The B Reactor Phase II Feasibility Study contract was awarded.

The Integrated Priority List (IPL) was completed for the FYO2 budget submittal

Six Tri-Party Agreement milestones were completed in February, all ahead of schedule

The In Situ REDOX Manipulation (ISRM) well drilling commenced in February in the $100 \mathrm{D}$ Area.

Phase I investigation sampling was completed for the 618-11 Burial Ground elevated tritium investigation.

All five groundwater pump and treat systems operated at or above the planned $90 \%$ availability levels through

February.

Collection and staging of legacy waste for shipment was initiated at KW Reactor.

Completed the Non-Destructive Evaluation (NDE) of crane drum at 221-U canyon (CDI) and issued the final report.

\section{MAOR COMMITMENTS:}

\section{Tri-Party Agreement Milestones}

Eleven Tri-Party Agreement milestones have been completed through February, all ahead of schedule. Six TriParty Agreement milestones were completed during February. The installation of RCRA groundwater monitoring wells were completed as of February 17. The well installations satisfied completion of Tri-Party Agreement milestones M-24-00K, M-24-41, M-24-42, M-24-43, M-24-44, M-24-45.

\begin{tabular}{|c|c|}
\hline Total Tri-Party Agreement Milestones Due in FYOO & 16 \\
\hline Total Planned Through February & 11 \\
\hline Total Completed Through February & 11 \\
\hline
\end{tabular}

\begin{tabular}{|l|l|}
\hline Remaining Milestones to be Completed in FYOo & $\boldsymbol{5}$ \\
\hline Forecast Ahead of Schedule & 1 \\
\hline Forecast On Schedule & 4 \\
\hline Unrecoverable & 0 \\
\hline
\end{tabular}

High Visibility Project Mllestones

Transmit Update of the Vadose Zone Science and Technology Roadmap (PBS VZO1) due April 30.

Status: Forecasted to be complete by April 28. 


\section{ENVIRONMENTAL MANAGEMENT PERFORMANCE REPORT ENVIRONMENTAL RESTORATION \\ APRIL 2000}

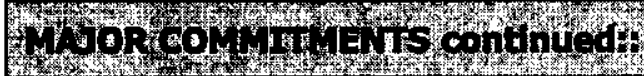

Complete Installation of the Wells and Initiate Injection of the Barrier for Phase 2 of the In Situ REDOX

Manipulation Project (PBS ERO8) due September 30.

Status: Forecasted to be complete by September 30.

Other Major Milestones

Develop and Implement Integrated Safety Management (ISM) due September 30.

Status: On schedule. 


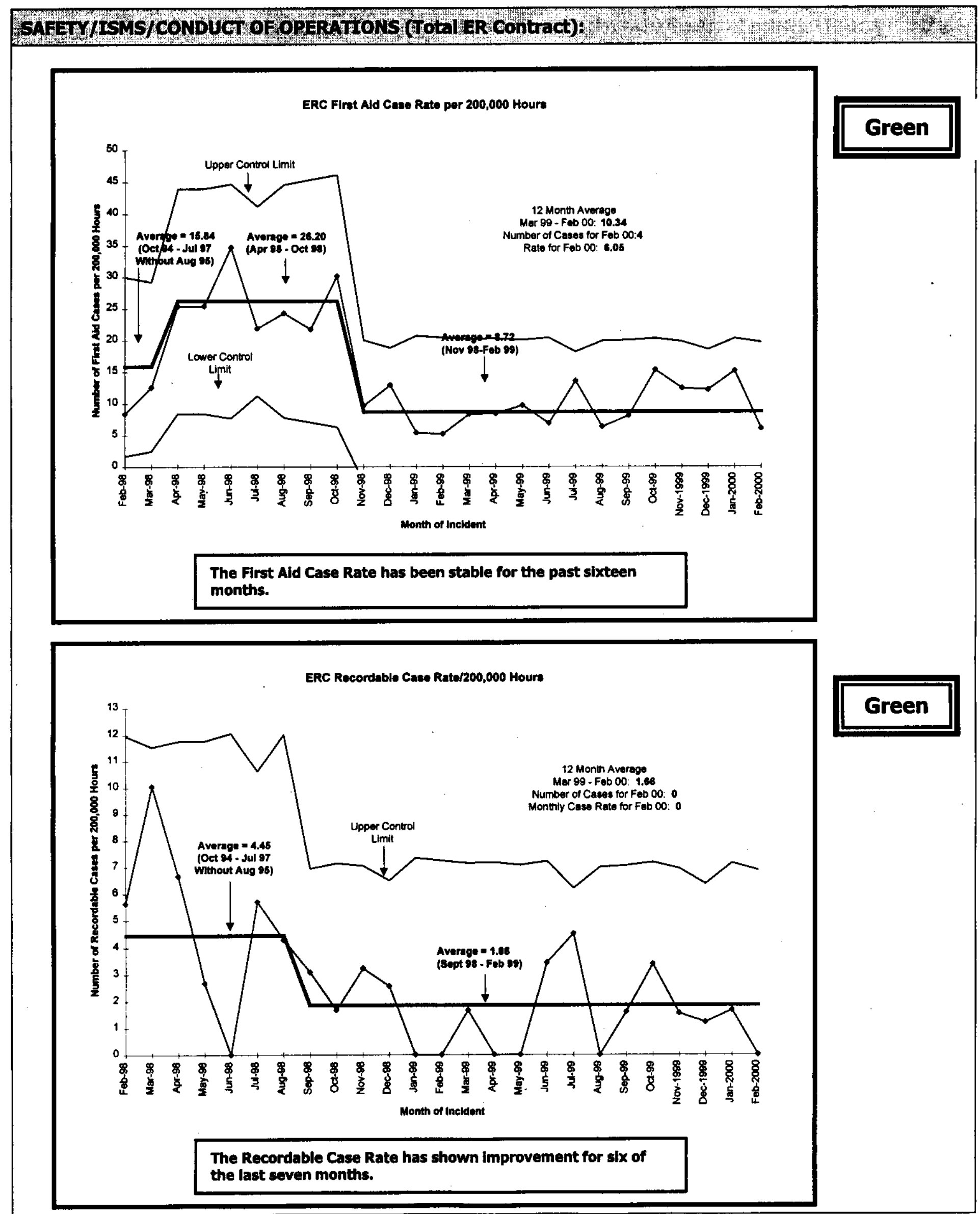




\section{ENVIRONMENTAL MANAGEMENT PERFORMANCE REPORT ENVIRONMENTAL RESTORATION}

APRIL 2000

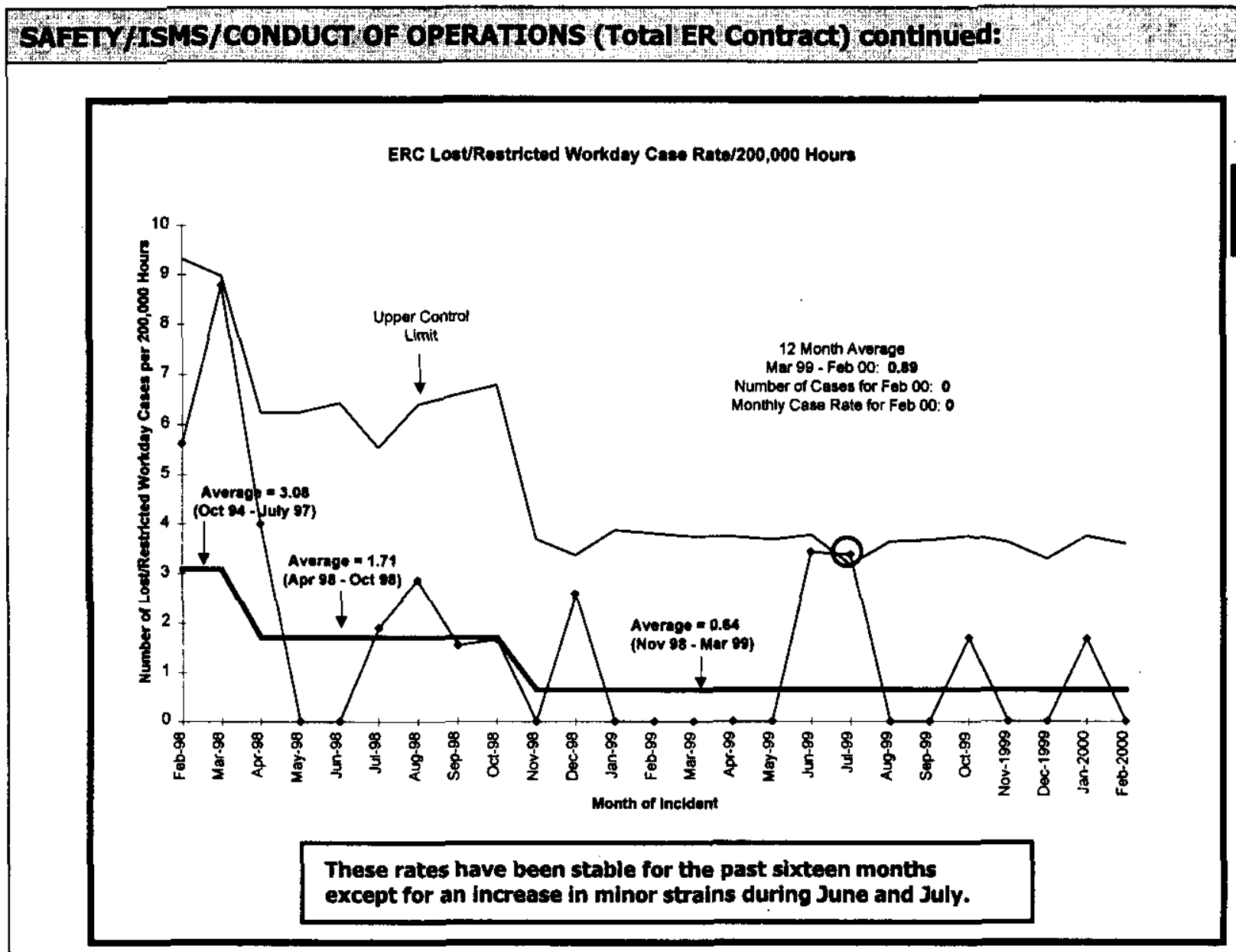

Green

- Safety:

\begin{tabular}{|l|c|c|c|}
\hline \multicolumn{1}{l|}{} & $\begin{array}{c}\text { Fiscal } \\
\text { YTD }\end{array}$ & $\begin{array}{c}\text { Current } \\
\text { Month } \\
\text { (Feb) }\end{array}$ & \multicolumn{1}{c|}{ Current Month Comments } \\
\hline First Ald & 39 & 4 & $\begin{array}{l}\text { (1) abrasion, (1) strain, (1) contusion, (1) } \\
\text { exam for puncture }\end{array}$ \\
\hline Last/Restricted Work Case & 1 & 0 & N/A \\
\hline Last Work Day Case & 1 & 0 & N/A \\
\hline OsHA Recondable & 5 & 0 & N/A \\
\hline
\end{tabular}

-As of 3/18/00, the ERC has worked approximately 643,250 hours since last lost workday case.

- ISMS:

DOE EM Performance Agreement: Develop and implement Integrated Safety Management (ISM) September 30.

Status: The Kick-Off meeting was held on March 2 and followed by a site tour on March 3. Phase I Verification interviews were completed on March 8, and Phase II Verification interviews were completed on March 16. The DOE Verification Team is currently completing their report. A final debriefing will be presented to BHI Senior Management on Thursday, March 23 prior to the debrief of Keith Klein later that day. 


\section{ENVIRONMENTAL MANAGEMENT PERFORMANCE REPORT ENVIRONMENTAL RESTORATION \\ APRIL 2000}

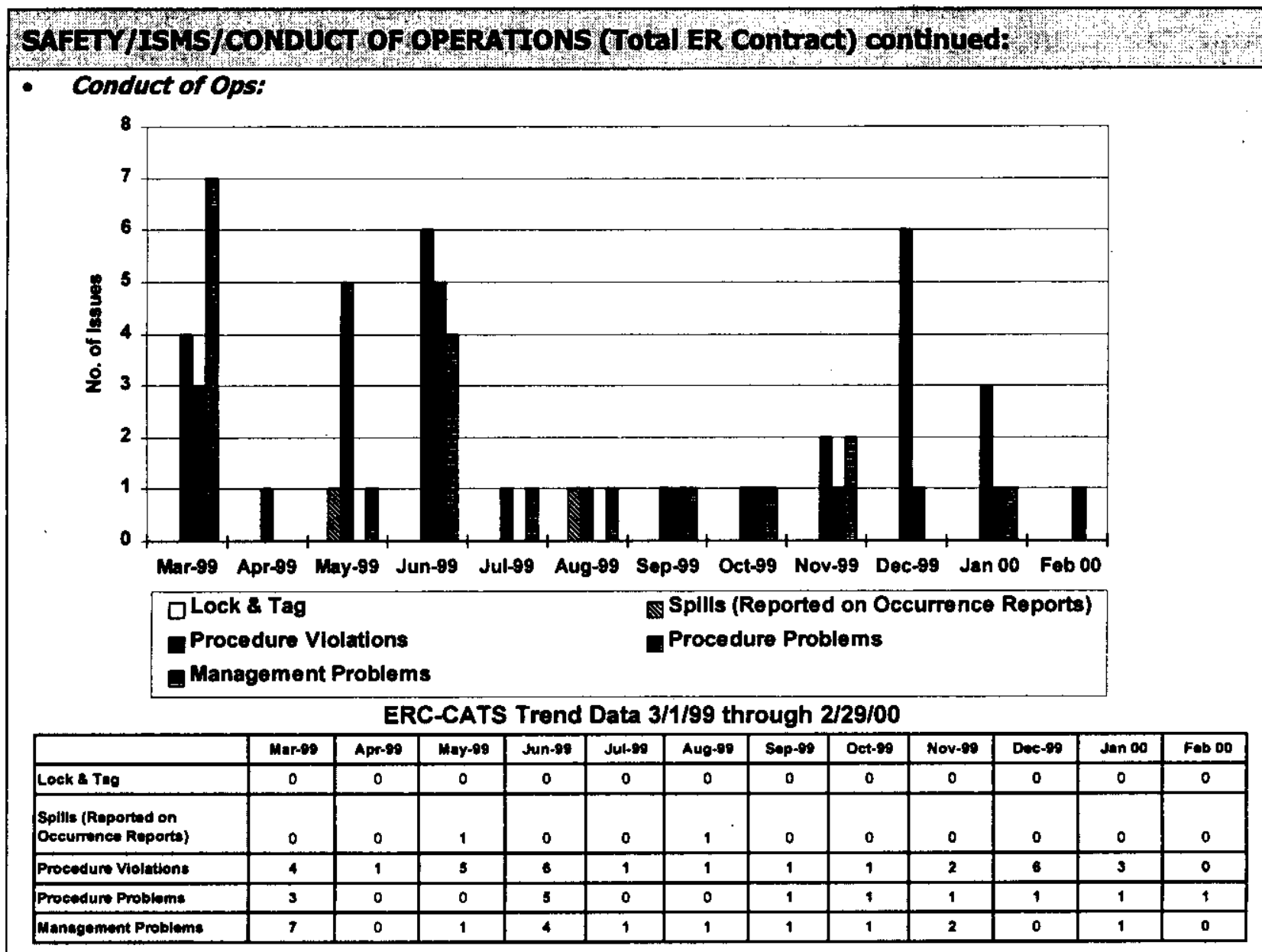

\section{Eebruary Conduct of Ops Iscues:}

\section{Procedure Problem:}

Condition Description: A procedure does not exist for the operation of the OMI Force 1750 CFM exhauster, nor is there a requirement for the operation of the exhaust required in the work control program.

Corrective Action Plan: BHI-FS-01, Field Support Administration, Procedure 2.3 "Task Instruction Development" is being revised (Revision 3) to include requirements of providing operating instructions when a tool is used in the performance of a task, and if the tool has operating limits. The determination when operating limits are provided in the task instructions is when a failure in the operation of the tool may impact the safety of the workers, the public, or the environment.

\section{REGULATORY /EXTERNAL/DOE RL 6 HQ WSSUES AND REQUESTS:}

Waste Control Plan: One hundred and forty-five drums of drilling cuttings, s/urries, and miscellaneous sampling wastes are currently being stored in a central location in the 200 West Area (BioSite). The majority of the wastes were recently generated (November, 1999 to February, 2000) by well drilling activities associated with the eight RCRA wells drilled under the M-24 TPA milestone with a minor amount from the 618-11 tritium investigation and 100 Area investigations. The waste was managed under a Waste Control Plan developed by BHI and approved by Ecology, Department of Energy - Richland (DOE-RL) and Bechtel Hanford Incorporated (BHI) in September, 1999. Ecology was considered the regulatory lead for such wastes and was the only regulatory agency to approve the plan. The site where the waste is stored is in an EPA-lead operable unit (200-ZP-02).

On February 14, Ecology issued a letter stating that they intended to rescind the September, 1999 Waste Control Plan effective 30 days (March 16) from receipt of the letter. The letter stated that Ecology found the plan to be excessively broad and that Ecology and EPA. would entertain development of operable unit specific waste control plans. 


\section{ENVIRONMENTAL MANAGEMENT PERFORMANCE REPORT ENVIRONMENTAL RESTORATION \\ APRIL 2000}

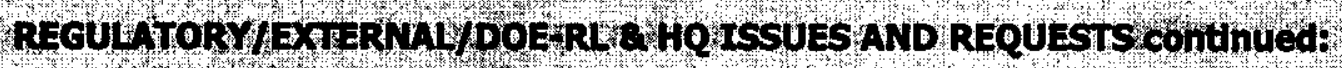

During a meeting with EPA and Ecology on February 24, EPA voiced concerns relative to the September, 1999 Waste Control Plan only being signed by Ecology, the statement that Ecology was the lead regulator for this waste, and the storage of the waste in a EPA lead operable unit.

Status: EPA and Ecology provided a letter, which allows the continued storage of waste at the Biosite in 200 West. ER continues to work with the regulators to determine the final disposition of the Biosite waste and storage and disposition of newly generated waste.

Site Wide Seniority (SWS): Current BHI/THI manual staffing totals 269 personnel. Approximately 225 position openings will become available within the Fluor Hanford organization during FYO0. Currently, 70 BHI/THI personnel have applied for transfer through the LAMP (Labor Assets Management Program) Process. Continued loss of personne/ will result in additional costs and potential impacts to critical work path activities.

Status: Lamping of ERC personnel has begun. For the months of January and February, 18 personnel have transferred to Fluor Hanford. A site wide strategy is required to maintain trained and critical resources on ER work. Lamping of personnel has resulted in additional costs associated with the training of new personne/ without compensation from the receiving organization.

Travel: Currently, no formal DOE-HQ guidelines have been issued. DOE Travel Guidelines evolved November through January. The DOE-HQ ERC limit is $\$ 330 K$ for travel. The submittal used to establish the \$330K funding limit did not include actual cost data for any non-ER programs, such as the Office of Science and Technology (DOE-S\&T) and the National Analytical Management Program (NAMP). In this scenario, performing non-ER work and travel directly erodes our ER travel base. Any future additional programmatic funding from non-ER sources would present the same kind of problem.

Status: The consequence is an impact to the DOE/ERC mission; placing compliance of DOE Orders in jeopardy, causing reduced contractor support for other sites and DOE programs, and causing additional contractor liability without renumeration.

Funding: FYO1 and FYO2 ER funding (target) levels are below minimum compliance requirements. Submitted FYO1 President's budget assumes ER funding target at \$143M. While this funding level maintains a number of significant activities supporting site cleanup goals, it is far short of maintaining compliance with TPAVother Regulatory commitments for the near term and especially beyond FY01. The recently directed funding target for FY02, at $\$ 140.1 \mathrm{M}$, is again significantly short of supporting minimum compliance requirements for FYO2 and beyond.

Issues, not funded, that need to be addressed in FY2001 and FY2002 include:

- 200 Area Characterization

- Canyon Disposition Initiative

- B-Reactor Museum

- Historic Building Mitigation Project

- 200-UP-1 Pump-and-Treat

- 200-ZP-2 Vapor Extraction (Continued Operations, DNAPPLE Investigation)

- Start of 224-B D\&D

- 618-10 and 618-11 Interim Actions

- Well Installation

- Well Decommissioning

- In-Situ Redox (ISRM) Technology Expansion

Status: Maintain current TPA/Regulatory commitments in FYOO; develop impacts associated with directed funding targets for FYO1 and FYO2, and support DOE budget submittals and presentations, including discussions with Regulators on projected future shortfalls and prioritization of allocated funding.

Emerging Work: Emergence of priority work is impacting the ERC's ability to initiate stretch and superstretch work activities. 


\section{ENVIRONMENTAL MANAGEMENT PERFORMANCE REPORT ENVIRONMENTAL RESTORATION \\ APRIL 2000}

\section{REGULTTORY/EXTERNA / DOE RL 8 HQ ISSUES AND REQUESTS continued:}

Status: $A$ BHI/DOE team was convened to evaluate options. The preliminary recommendation of the team is to include critical emerging work in the stretch category if the Results Management Team (RMT) determines that its priority is higher than existing stretch goals. This recommendation was taken to the RMT, and guidance was given to bring the issue to RL management for discussion. In addition, $B H I$ is developing a proposal for resolution of this and other Performance Incentive (PI) issues. 


\section{ENVIRONMENTAL MANAGEMENT PERFORMANCE REPORT ENVIRONMENTAL RESTORATION APRIL 2000}

\section{TOTAL COSW/SCHEDULE OVERVIEW (TotaIER Contrect)}

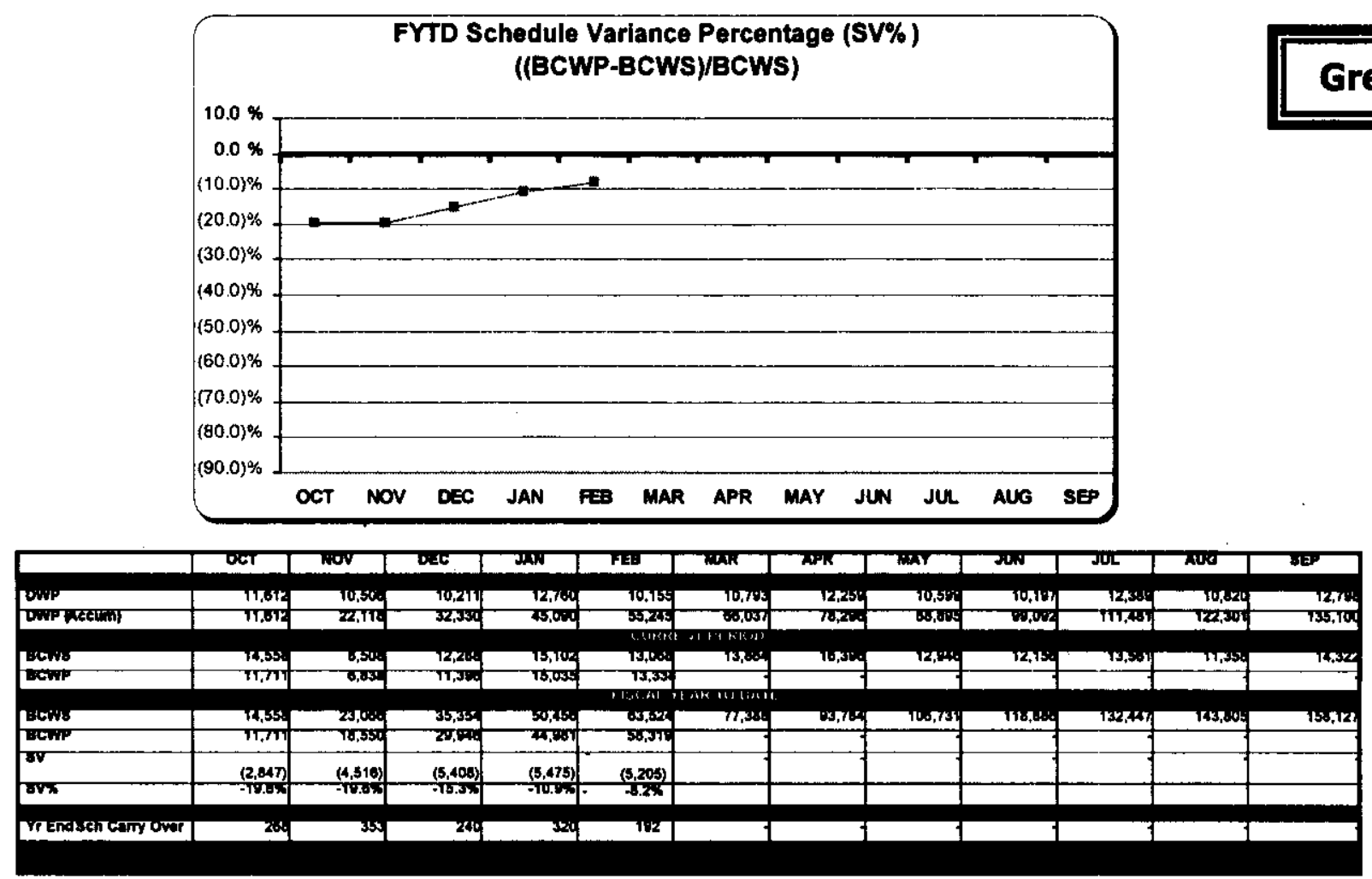

For variance explanation by PBS see Project Status Section of each project.

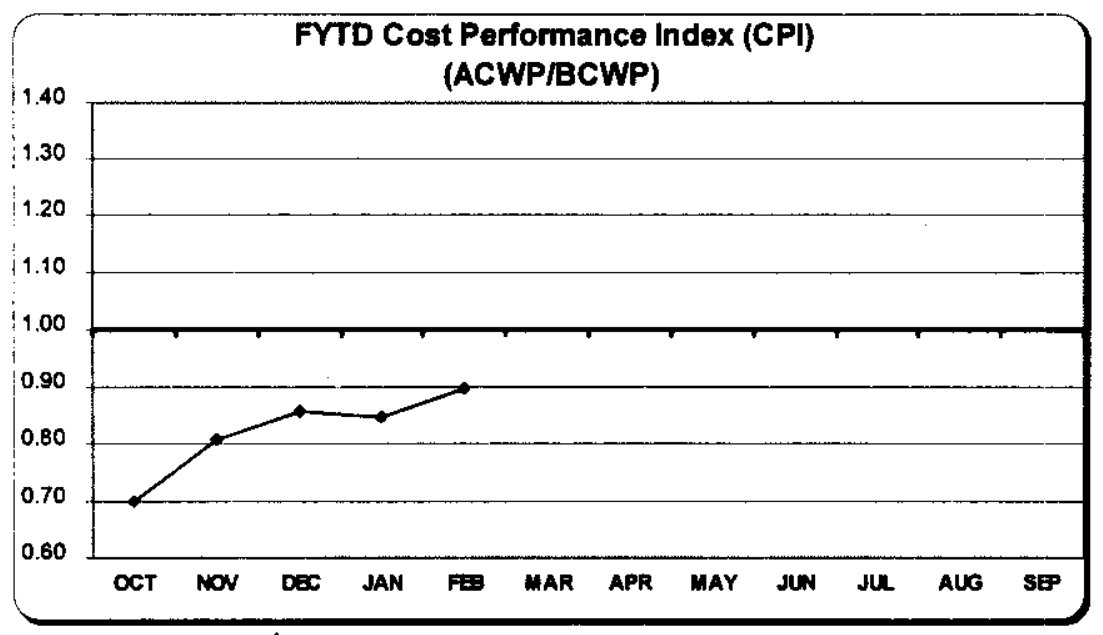

Green

Desired performance is 1.0 or less.

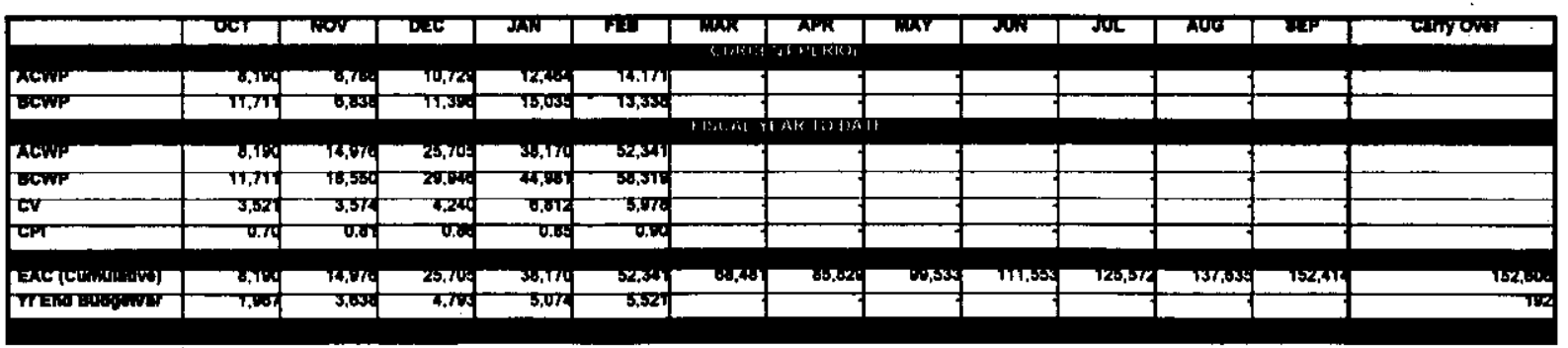

For variance explanation by PBS see Project Status Section of each project. 


\section{ENVIRONMENTAL MANAGEMENT PERFORMANCE REPORT ENVIRONMENTAL RESTORATION \\ APRIL 2000}

\section{TOTAL 005 / SCHEDULE OVERVMEW (Total ER Contract) continued:}

\section{FY2000 PERFORMANCE \\ FYTD FEBRUARY 100}

Green

$(\$ K)$

\begin{tabular}{|c|c|c|c|c|c|c|c|c|c|c|c|}
\hline & & & & & & $Y$ & & & YTD & & \\
\hline & $\begin{array}{l}\text { DWH } \\
\text { BCWS }\end{array}$ & $\begin{array}{l}\text { CUFPENT } \\
\text { BCWS }\end{array}$ & BCWS & $\begin{array}{l}\text { FYID } \\
\text { BCWP }\end{array}$ & ACWP & SCHEDULE & JANCE & $\frac{\operatorname{cosT}}{5^{-1}}$ & \begin{tabular}{l} 
VARIANC \\
\hdashline
\end{tabular} & $\mathrm{CP}$ & $\begin{array}{l}\text { FYOO } \\
\text { EAC }\end{array}$ \\
\hline & 27,504 & $30,5,0$ & 11,801 & 11,921 & 9,750 & 69 & $0.5 \%$ & 2,160 & $182 \%$ & 0.82 & 28,504 \\
\hline & 3,157 & 6,900 & 3,3804 & 3,163 & 2144 & -211 & $-6.4 \%$ & T,019 & $322 \%$ & 0.68 & 5,720 \\
\hline & 16,140 & 19,9क्य & 8,80र्ब & 8,758 & 7,483 & -480 & $-0.5 \%$ & T,275 & $746 \%$ & 0.80 & 18,800 \\
\hline reasidetiond & 43,607 & $37,3 \times 4$ & 24,047 & $23,8,44$ & 19,305: & -200 & $-49 \%$ & 4,450 & 187/9 & W.1 & 5,180 \\
\hline & 3,534 & 3,908 & 280 & 2,785 & 7,821 & -117 & $-38 \%$ & प्र०4 & $34.6 \%$ & 0.65 & 2,877 \\
\hline & 19,304 & 22,360 & 70,160 & 8,130 & $7,8 \pi 7$ & -2024 & $-19.9 \%$ & 209 & $32 \%$ & 0.97 & 22020 \\
\hline 4 & 11,325 & 17,431 & 4,504 & 3,6020 & 3,542 & -817 & $-18.0 \%$ & T50 & $4.1 \%$ & 0.90 & T1,2001 \\
\hline CWV S Suthrith & $34,2, x+4$ & $3 /, 7, \infty$ & $17, \ldots$ & 4,613 & 73,240 & $-2,900$ & $-168 \%$ & T,373 & प्रa/ब & 0.91 & 3,539 \\
\hline & 8,4i6 & 16,173 & 6,420 & 5,854 & 5,024 & -520 & $-82 \%$ & 274 & $4.6 \%$ & 0.90 & 75,967 \\
\hline Wosithex.4 & 87. & 16,113 & $6 \times 24$ & 5,80x & 5004 & -2000 & $72 \%$ & $2 / 4$ & $20 \%$ & 090 & 15,507 \\
\hline & 12,291 & 13,804 & 5,257 & 4,758 & 4,920 & $-4+5$ & $-9.5 \%$ & -161 & $34 \%$ & T.0S & 14,041 \\
\hline $2+1, n$ & 47 & $4 \pi$ & & & TIf & o & $0.0 \%$ & - & $-256.7 \%$ & 3.67 & 51) \\
\hline 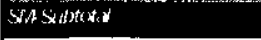 & $12,3 \times$ in & 13,500 & 5,200 & 4,76y & 4,93iा & 280 & 295\% & -10:8 & -3.5\% & 7.0. & 7400s: \\
\hline sid & 27,597 & 25,344 & 7,137 & 7,134 & 7,090 & -3 & $0.0 \%$ & 44 & $0.6 \%$ & 0.98 & 25,137 \\
\hline 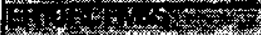 & 5,800 & 7,0204 & $3,0 \mathrm{SO}$ & 2,075 & 2,015 & $-1,024$ & $330 \%$ & 0 & $0.0 \%$ & 1.09 & 7,028 \\
\hline 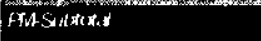 & $35,5: 11$ & 32914 & 10, $2 \times$ io & 9,00: & 9,100 & $-1,04$ & $-100 \%$ & 74 & a.j\% & 1.00 & 32,700 \\
\hline GAND IOIAL & 135,101 & 758,129 & $63,52 / 4$ & $58,3<0$ & $3 x, 341$ & $-0,2,044$ & 7.2\% & 5,979 & $10.3 \%$ & 0.50 & 152,600 \\
\hline
\end{tabular}

${ }^{*} C P I=A C W P / B C W P$

\section{Cost/Schedule_Status:}

Cost Variance: At the end of February, the ER Project had performed \$58.3M worth of work, at a cost of $\$ 52.3 \mathrm{M}$. This accounts for a favorable cost variance of $\$ 6.0 \mathrm{M}(10.3 \%)$. The positive cost variance is attributed to site excavation savings, borehole drilling and test pit trenching costs less than planned (due to efficiencies), ISS equipment costs less than planned.

Schedule Varlance: The ER Project is $\$ 5.2 M(-8.2 \%)$ behind schedule for February. The negative schedule variance is attributed to delays in GWNZ science and technology (5\&T) activities; undetermined GWNZ subpanel schedules; groundwater well maintenance, resin regeneration/purchase and monitoring; 233-S Facility loadout hood waste removal (awaiting waste container procurement), and roof duct removal, sampling, and analysis; 224-B Facility inspection/survey (delays due to inoperable exhaust system repairs); and late billings for site-wide assessments.

\section{PERFORMANCE OBJECTIVES:}

River Corridor Inithative (Complete remediation of 60 sq. miles, including Hanford townsite): Initiative is currently identified as a superstretch item, with an approximate value of $\$ 5.0 M$. High visibillty public access opportunities; also a superstretch item (bike trail, road to $B$ Reactor, and boat ramp at Hanford townsite). Feasibility plan completed and is in review.

Status: Under development. 


\section{ENVIRONMENTAL MANAGEMENT PERFORMANCE REPORT ENVIRONMENTAL RESTORATION \\ APRIL 2000}

\section{CEX INTEGRAMON A CMVMUES:}

The ERDF successfully completed handling its first waste stream from outside the ERC. Transportation and disposal of demolition waste from the 331-A building (located in the 300 Area) took place from February 21 to March 6. Teaming and coordination between all parties (PNNL, FHI, ER's D\&D and RAWD Projects) were excellent, and the job proceeded smoothly.

\section{UPCOMHC PUAWED KEY EVENTS:}

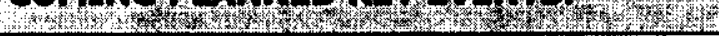

Obtain regulator approval for Tri-Party Agreement Milestone M-16-08B, Complete Remediation and Backfill of 19 Waste Sites in the 100 BC-1 and 100-BC-2 Operable Units, due March 31. (Backfill activities for the Group 3 waste sites were completed on February 25.) 


\section{Richland Operations Office Environmental Restoration \\ Environmental Management Performance Report}

\section{Section B - River Corridor Informąitoll}

\section{April 2000}

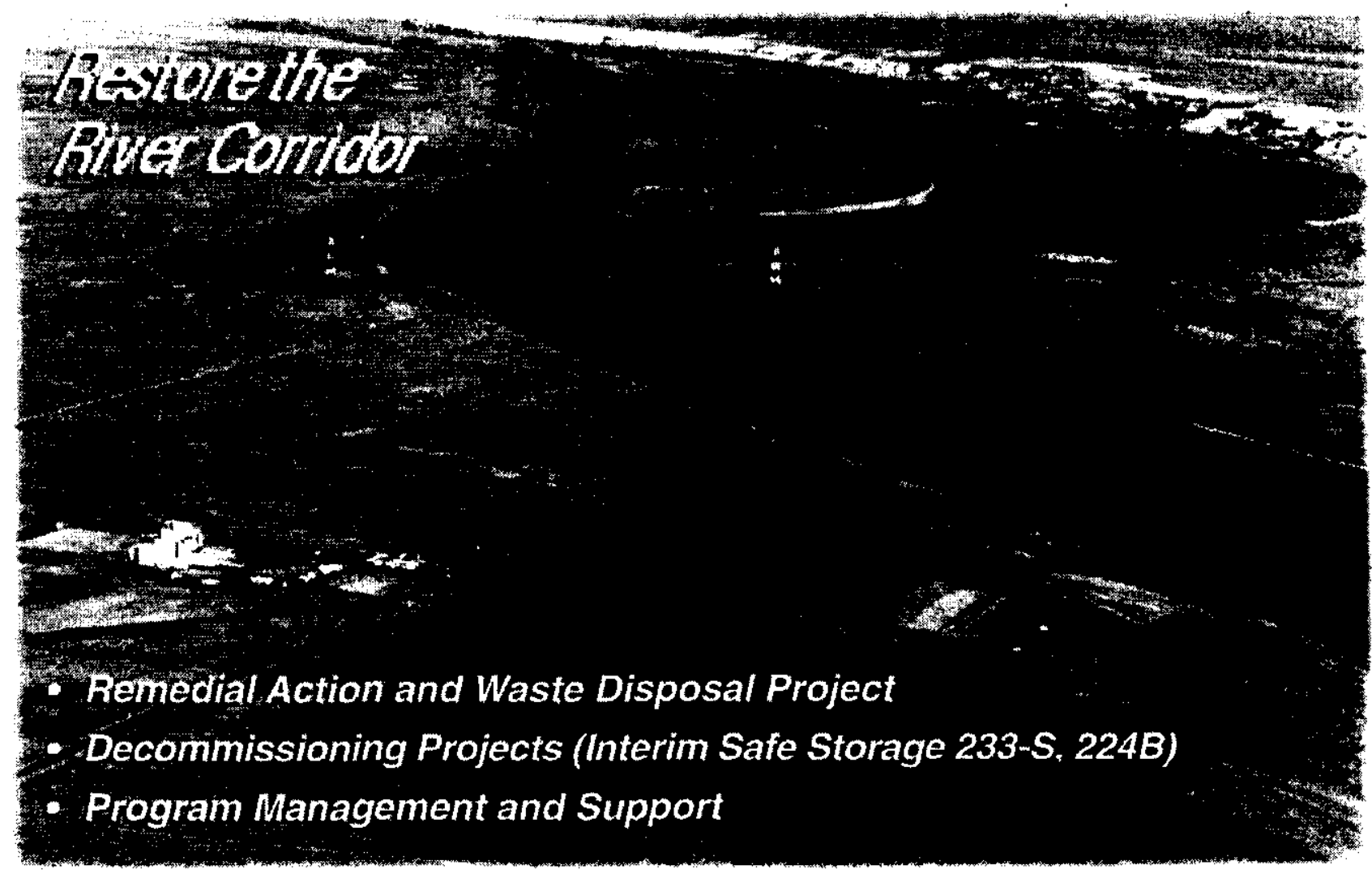

Focused on Progress...

Focused on Outcomes! 
ENVIRONMENTAL MANAGEMENT PERFORMANCE REPORT ENVIRONMENTAL RESTORATION

APRIL 2000

\section{Remedial Action and Waste Disposal Project (RAWD)}




\title{
ENVIRONMENTAL MANAGEMENT PERFORMANCE REPORT ENVIRONMENTAL RESTORATION APRIL 2000
}

\section{SECTION B - RESTORING THE RIVER CORRIDOR}

\author{
Financial data as of month-end February. All other data as of March 23, unless otherwise noted.
}

Remedial Action \& Waste Disposal Project (RAWD):

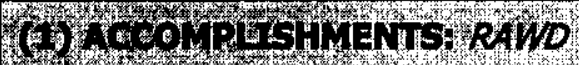

Overall: During February, shipments totaling 52,105 metric tons (57,436 tons) of contaminated waste were transported to the ERDF. 245,142 metric tons $(270,224$ tons) have been received in FYOO. To date, $1,972,118$ metric tons $(2,173,899$ tons) of material have been received and placed in the disposal facility.

Excavation of waste sites at 100-D, 100-H, and 300 Area in progress.

$100 \mathrm{D}$ Area Remedial Action: 60" steel pipe removed, within 100 feet of DR reactor, was completed. Closeout and backfill of this section is being accelerated to restore access for ISS activities.

Backfilling of the twelve Group 3 sites at 100-B/C was completed on February 25. This backfilling will satisfy completion of TPA Milestone M-16-08B.

$100 \mathrm{H}$ Area Remedlal Action: Significant progress was made on pipeline removal. 138 meters (453 feet) of 1.5 meter (60) diameter steel pipe, 41 meters (135 feet) of 0.15 meter (67) diameter vitrified clay pipe, and 174 meters (570 feet) 0.5 meter (207) diameter steel pipe was removed. Four expansion boxes were demolished. Completion of the pipeline north of $\mathrm{H} 7$ would have been completed, but two compressed gas cylinders were uncovered. The cylinders were explosively punctured, one by the Richland Police Department Bomb Squad and one by the Washington State Patrol.

$100 \mathrm{~N}$ Area Remedial Action: Soil remediation at 100-N is scheduled to begin in July to meet the requirements of the Hanford Site RCRA permit. Procurement activities are underway to acquire the services of an excavation/remediation subcontractor. Six proposals were received on February 3. A technical review of the proposals indicated that clarifications were required from all bidders. Clarifications and bidder's Best Revised Offers were received on February 23. Commercial and technical evaluations are continuing. Oral interviews were conducted on March 7-8. Anticipate subcontractor award in early April.

300 Area Remedial Action: Numerous drums are being unearthed at Landfill 1A. Most are empty and crushed, but a few are intact and may contain wastes. Historical records are being reviewed and sampling plans are being prepared. Also, some packaging/absorbent material consisting primarily of newspaper has been found with relatively high radiological contamination. A legible portion of the newspaper indicated it was a 1953 issue of the Oregonian. The subcontractor has chosen to use a power screen at Landfill $1 A$ to help facilitate the debris sorting process.

(2) SAFETT/ISMS/CONDUCT OF OPS, RAWD See Cross-Cutting Package.

(3) BREAMTHROUGHS/OPPORTUNIIES FORIMPROVENENTI RAWD Waste Minimization 126-F-1 Ash Plt: Final Report on the 126-F-1 Waste Minimization Project will be completed by the end of March. A copy of the report will be provided to the Hanford Waste Minimization Program in early April. The project deployed two off-the-shelf technologies (geo-probe and sodium iodide detector) to perform in-situ characterization that resulted in $50 \%$ reduction in waste site volume. Preliminary cost savings is estimated at \$5M.

(4) LONG-TERM (6 MONMHS PL US) IHPO IU WT MEMSA RAWD

300-FF-2: Work is ongoing to prepare decision documents for the public review period scheduled for late May. Ecology has issues with the Preliminary Remediation Goals (PRG's) being developed for 300-FF-2. EPA, who supports the PRG's, will be addressing issues with Ecology with support from RL.

Status: Work is ongoing to prepare decision documents for the public review period scheduled for late May. 


\section{ENVIRONMENTAL MANAGEMENT PERFORMANCE REPORT ENVIRONMENTAL RESTORATION \\ APRIL 2000}

(4) LOH G DEPM (6MONTHSPLUS) IMPORTANT TTEMS continued, RAWD

100 Area Burial Grounds: Approval of the ROD is planned by August 30. Currently tracking on

schedule; no issues.

Green

(6) MAOR COMMITMENTS (FISCAL YEAR PLUS 6 MONTHS), RAWD

- (5A) DOE Secretarial:

None identified at this time.

- (5B) DOE EM Performance Agreement:

None identified at this time.

- (5C) TPA Mllestones:

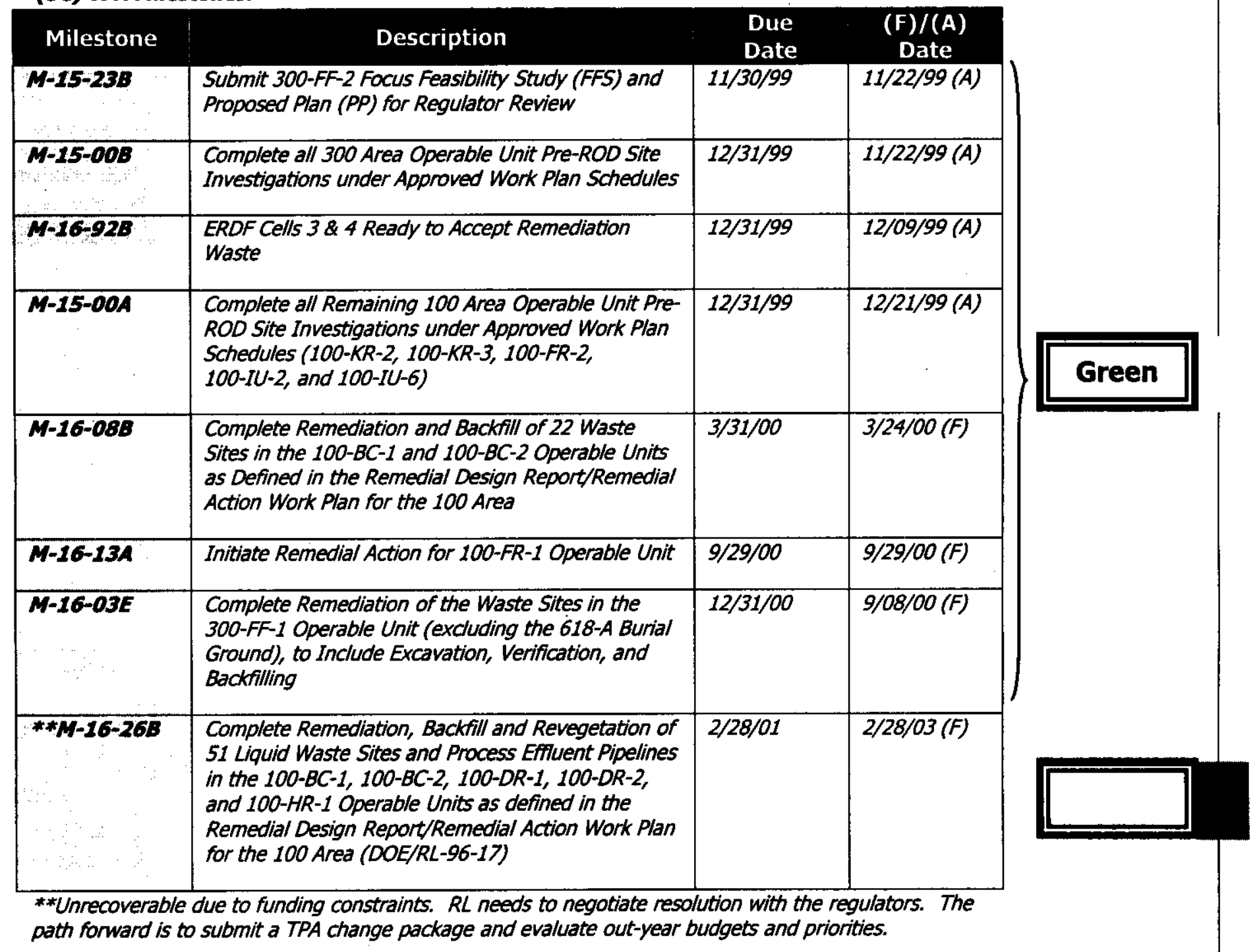

- (5D) DNFSB Commitment:

None identified at this time. 


\section{ENVIRONMENTAL MANAGEMENT PERFORMANCE REPORT ENVIRONMENTAL RESTORATION \\ APRIL 2000}

(6A) PER YORYAW GE OBNECTIVES: RAWD

\begin{tabular}{|c|c|c|}
\hline Outcome & Performance Indicator & \multicolumn{1}{c|}{ Status } \\
$\begin{array}{c}\text { Restone the Rhor Gormidor } \\
\text { Ror Mutplowses }\end{array}$ & $\begin{array}{l}100 / 300 \text { Area waste excavation, } \\
\text { disposal and backfill/regrade. }\end{array}$ & $\begin{array}{l}\text { Baseline work is projected to be } \\
\text { completed per PI requirements. }\end{array}$ \\
\hline
\end{tabular}

\section{Green}

(6) IFED W WOENEASURES: RAWD - (River and Plateau)

\begin{tabular}{|c|c|c|c|c|}
\hline & $\begin{array}{l}\text { DWP } \\
\text { FY00 }\end{array}$ & $\begin{array}{l}\text { Current Baseline } \\
\text { (Incl. Baseline } \\
\text { Changes) }\end{array}$ & $\begin{array}{l}\text { Forecast } \\
\text { For FYOO }\end{array}$ & $\begin{array}{c}\text { Completed } \\
\text { YTD }\end{array}$ \\
\hline Wostrstes & 24 & 41 & 41 & 9 \\
\hline 100 Aro Surtal Ground & 0 & 47 & 47 & $47^{*}$ \\
\hline $300-7 \%-2$ Asseaspments & 121 & 121 & 121 & $121^{*}$ \\
\hline Tons $\quad$, & $389 K$ & $600 \mathrm{~K}$ & $600 \mathrm{~K}$ & $309 K$ \\
\hline
\end{tabular}

*Proposed Plan, Draft A submittal

(6C) STRETCH AND SUPERSTRETCH GOALS, RAWD

\begin{tabular}{|c|c|c|}
\hline FY00 "Stretch" Goals & $\begin{array}{c}\text { Scope } \\
\text { Dollars (K) }\end{array}$ & $\begin{array}{l}\text { Approved } \\
\text { BCPs (K) }\end{array}$ \\
\hline 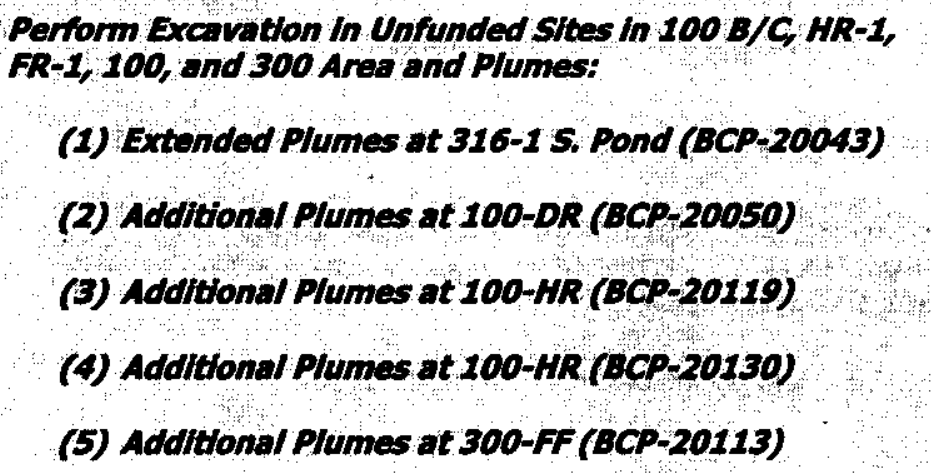 & & $\begin{array}{r}\$ 1,202.8 K \\
\$ 905.8 K \\
\$ 240.3 K \\
\$ 426.7 K \\
\$ 669.4 K\end{array}$ \\
\hline S/Total Remediation Action Stretch Goalst & $\$ 4,560.0 \mathrm{~K}$ & $\$ 3,445.0 K$ \\
\hline
\end{tabular}




\section{ENVIRONMENTAL MANAGEMENT PERFORMANCE REPORT ENVIRONMENTAL RESTORATION \\ APRIL 2000}

(6C) STRTTEH WD SUPERSTR TCH COALS contlnued, RAWD

\begin{tabular}{|c|c|c|}
\hline FY00 "Super Stretch" Goals & $\begin{array}{c}\text { Scope } \\
\text { Dollars }(K)\end{array}$ & $\begin{array}{l}\text { Approved } \\
\text { BCPs (K) }\end{array}$ \\
\hline Complete Remedtation of $60 \mathrm{sq}$. Ml of Hanford siter & & \\
\hline (1) Complete Remediation of Hanford Townsite & $\$ 755.0 K$ & $\$ 0.0 K$ \\
\hline (2) completa Remedlation of JA Jones PIt *1 and & $\$ 1,500.0 K$ & $\$ 0.0 K$ \\
\hline (3) Other Rbmedla/Actions & & $\$ 0.0 K$ \\
\hline S/Total Remediation Actic & $\$ 3,650.0 K$ & $\$ 0.0 K$ \\
\hline
\end{tabular}

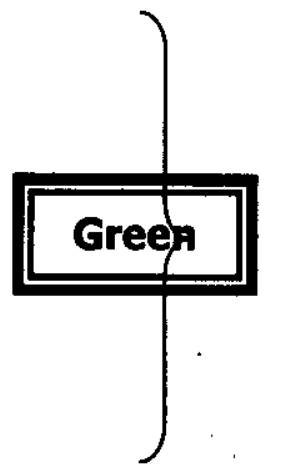

Status: Plan and estimate developed, current work efforts focusing on stretch activities at this time.

\section{(7) PROJEMT STATUS (COST/SCHEDULE/MAJOR BASELINE CHANGE, RAWO}

\section{- (7A) Schedule:}

\begin{tabular}{|c|c|c|c|}
\hline \multirow{2}{*}{ Remedial Action \& Waste Disposal Project } & BCWS & BCWP & Variance \\
\hline & $\$ \mathbf{K}$ & $\mathbf{\$ K}$ & $\$ K$ \\
\hline ERO1 100 Anes Remodlal Actions & 11861 & 11921 & 60 \\
\hline ERO3 300 Aned Remedlal Actions & 3380 & 3163 & -217 \\
\hline ERO4 ER Waste OSpoosal & 8806 & 8758 & -48 \\
\hline TOTAL Remedial Actions & 24047 & 23842 & -205 \\
\hline
\end{tabular}

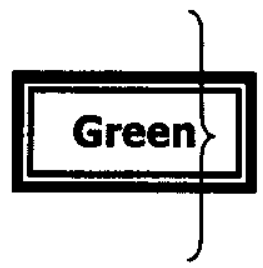

PBS-ER-01 - 100 Area Remedial Action

Schedule Variance $=[+\$ 60 K ;+0.5 \%]$ [Last Month: $(-\$ 747 K) ;(-8.1 \%)]$

Cause: On Schedule.

Resolution: Schedule improvement due to contractor accelerating DR backfill production.

PBS-ER-03 - 300 Area Remedial Action

Schedule Variance $=[(-\$ 217 K) ;(-6.4 \%)]$ [Last Month: $(-\$ 75 K) ;(-2.7 \%)]$

Cause: Delay in loadout of waste at Landfill 10 while waiting for regulator variance - minor impact not on critical path; Subcontractor has elected to work landfill $1 B$ before $1 A$ as originally scheduledtemporary schedule variance - will complete remediation on schedule.

Resolution: None required; will complete on schedule. Actually ahead of schedule based on tonnage quantities.

PBS-ER-04 - Environmental Restoration Waste Disposal

Schedule Variance $=[(-\$ 48 \mathrm{~K}) ;(-0.5 \%)]$ [Last Month: $(-\$ 115 \mathrm{~K}) ;(-1.6 \%)]$

Cause: Late start on ERDF closure design.

Resolution: None required - not critical - can complete before September. 


\section{ENVIRONMENTAL MANAGEMENT PERFORMANCE REPORT ENVIRONMENTAL RESTORATION

\author{
APRIL 2000
}

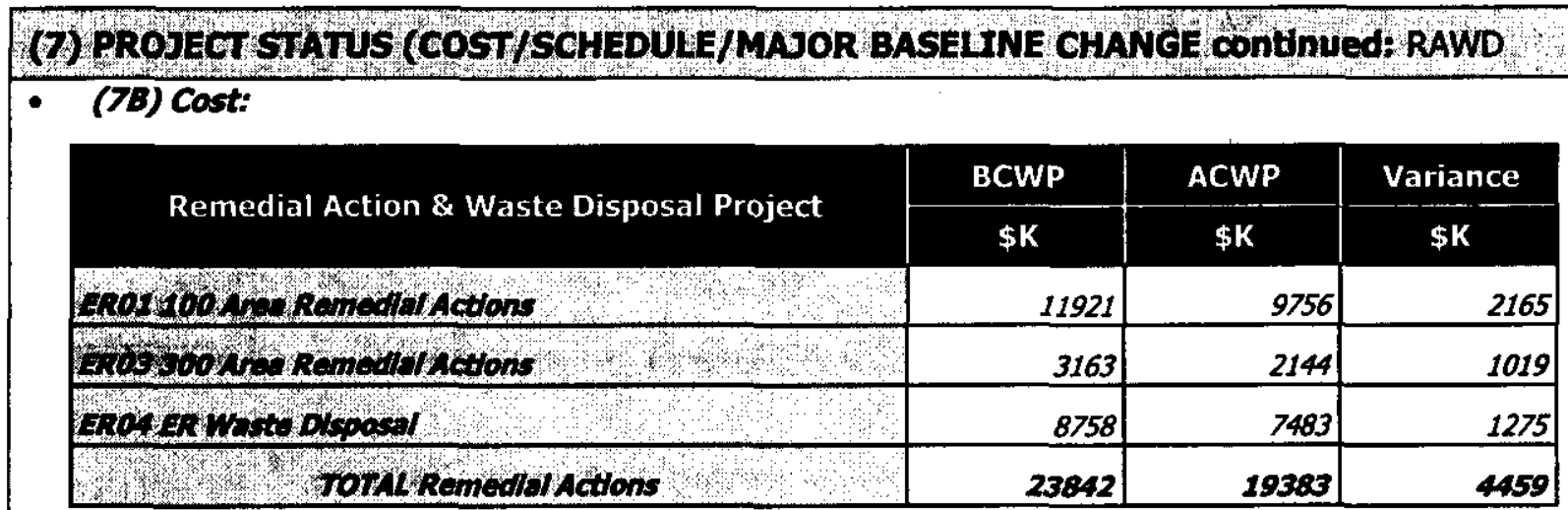

PBS-ER-O1 - 100 Area Remedlal Action

Cost Variance $=[+\$ 2165 K ;+18.2 \%$ ] [Last Month: $+\$ 1883 K ;+22.3 \%]$

Cause: DR contract award on small sites excavation was less than budgeted; FR savings in site prep and staff reductions; labor savings on $B / C$ backfill activities.

Resolution: Savings will be used to perform other remediation work.

PBS-ER-03 - 300 Area Remedlal Action

Cost Variance $=[+\$ 1019 K ;+32.2 \%]$ [Last Month: $+\$ 1286 K ;+47.5 \%]$

Cause: Management and administrative cost efficiencies at Landfills $1 A / 1 B$, and $\$ 500 K$ under accrual in South Process Pond remediation.

Resolution: Savings will be used to perform other remediation work.

PBS-ER-04 - Environmental Restoration Waste Dispostal

Cost Variance $=[+\$ 1.275 K ;+14.6 \%]$ [Last Month: $+\$ 1487 K ;+21.2 \%]$

Cause: Reflects FY99 over accrual.

Resolution: Savings will be used to perform other remediation work.

\section{(8) REGULATORY ISSUES, RAWD}

Tri-Party Agreement Mllestone: M-16-26B - Complete Remediation and Backfill of 51 Waste Sites at $B / C, D R$, and $H R$ by February 28, 2001 will be missed due to lack of funding for 100 Area $B / C$ pipelines.

Status: A resolution with the regulators is required to be negotiated. The path forward is to submit a Tri Party Agreement Change Package to the regulators for review and evaluate out year funding and priorities.

Arsenic Strategy for 100 Area Remedlation: Variance sampling was completed in November 1999 for 1607-H2 and 1607-H4 septic systems. Arsenic data in the overburden and shallow zone soils exceeded Remedial Action Goals (RAGs), (Hanford Background). The average ranged from $8-11 \mathrm{mg} / \mathrm{kg}$, maximum $30 \mathrm{mg} / \mathrm{kg}$; Hanford Background $6.5 \mathrm{mg} / \mathrm{kg}$. Records indicate that no arsenic was used in processes at the 100-H Area Historical research indicates lead arsenate was used as a pesticide in pre-Hanford agricultural lands (predominanty orchards). Application rates were as high as $250 \mathrm{lb}$. per acres per year. Lead arsenate pesticide was used from the early 1900's to 1942. By 1942, Hanford agricultural land is estimated at 13,000 acres dry land farming and 18,000 acres in irrigation districts.

Status: The state background value of 20 ppm (6 ppm was the Hanford background) will be utilized as the cleanup goal for the 100-H and F Operable Units. Ecology and EPA have agreed to this new clean up level. The Remedial Design Report and Sampling Analysis Plan are currently being revised to reffect this new cleanup value for arsenic. $A B C P$ will be processed in April to reflect the required cost and schedule impacts. 


\section{ENVIRONMENTAL MANAGEMENT PERFORMANCE REPORT ENVIRONMENTAL RESTORATION \\ APRIL 2000}

(9) EXTERNA1 ISSUES, (1E, HAB, congress, etc) R RAWD

None identified at this time.

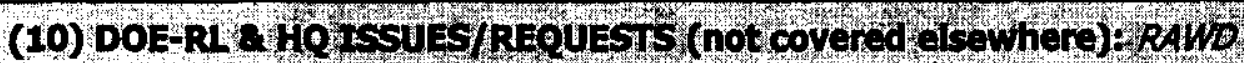

116-DR-1 \& 2: Closeout Verification sampling results show a Strontium-90 $\left(S S^{\circ}\right)$ plume in the shallow zone at 116-DR-1 \& 2. There are two issues:

Issue: Remediation of this plume may require additional funds and depending on size of the plume could delay start of backfill for the site.

Strategy: Closely monitor cumulative tons being excavated from approved plume scope. If tonnage exceeds approval levels, a BCP will be generated addressing the additional scope.

Issue: The presence of elevated concentration of $S^{90}$ was not detected prior to closeout sampling, as $S^{90}$ is a beta emitter not readily detectable with field screening.

Strategy: Review analytical process leading up to closeout to identify possible changes in approach (i.e. more sampling) for earlier indication of hard to detect isotopes.

(1i) INTEGRATHON ACTMITES: RAWD

$331 A$ Faclllty: The ERDF successfully completed handling its first waste stream from outside the ERC. Transportation and disposal of demolition waste from the 331-A building took place from February 21 to March 6. The demolition contractor, Fluor Federal Services, experienced an equipment- related delay that stretched the completion date out further than originally anticipated. Teaming and coordination between all parties (PNNL, Fluor, D\&D and RAWD) was excellent and the job proceeded smoothly. A lessons learned/feedback meeting has been scheduled in order to identify how ERDF processes can be optimized.

K-Basin Waste: ERDF personnel have been meeting with the members of the Spent Nuclear Fuels Project team in preparation for receiving $K$-Basins waste. At this point in time, the two groups have developed a schedule and are working on the DQO process. Preparation of Waste Shipping and Receiving Plans is underway. First shipment is scheduled for early June. 


\section{Decommissioning Projects (D\&D)}




\section{ENVIRONMENTAL MANAGEMENT PERFORMANCE REPORT ENVIRONMENTAL RESTORATION \\ APRIL 2000}

\section{SECTION B - RESTORING THE RIVER CORRIDOR}

Financial data as of month-end February. All other data as of March 23, unless otherwise noted.

\section{Decommissioning Projects (D\&D):}

\section{(1) ACCOMPLISHMENS: D\&D}

ISS: Completed demolition of the gas recirculation tunnel on February 11. This completes all demolition at F Reactor, with the exception of the Fuel Storage Basin.

The 105-D \& H Reactor Engineering Evaluation/Cost Analysis (EE/CA) and the 105-D Auditable Safety Analysis (ASA) Drafts are being finalized prior to submitting them to RL in March.

Awarded the SSE pourback subcontract for both F \& DR Reactors on February 7.

Completed an ASTD proposal requesting funds in support of the FReactor Fuel Storage Basin cleanout.

105-B: A meeting was held with the regulators on February 24 to discuss the TPA Milestone requirements and the path forward for the 105-B Reactor Safe Storage.

233-S: Process cell path forward BCP-20141 was approved.

Completed process hood panel removal and survey mock-up training.

Completed SER, criticality controls and postings training.

Completed asbestos abatement and cutting of two supply duct sections.

224-B: Submitted draft EE/CA for review and comment. Initiated planning to conduct 224-B walkdowns without $B$ Plant ventilation in operation.

\section{(2) SAFETY/ISMS/CONDUCT OF OPS: D\&D}

See Cross-Cutting Package.

\section{(3) BREAKTHROUGHS/OPPORTUNITIES FOR IMPROVEMENT D\&D}

233-S: The 233-S Radiological Control Supervisor (Kevin Funke) is experimenting with a digital camera and photo editing software to place actual photographs of survey locations into Radiological Control Survey Records. We are also attempting to extract a still photo from video taken in the process cell with the remote survey tool and include that in the survey records. Providing the workers with an actual work location picture with radiological survey information annotated on it, should give them a better physical understanding of the potential hazards.

\section{(4) LONG-TERM (6 MONTHS PLUS) IMPORTANT ITEMSA D\&D}

None identified at this time.

(5) MANOR COMMITMENTS (FISCAL YEAR PLUS 6 MONTHS) I D\&D

- (5A) DOE Secretarial:

None identified at this time.

- (5B) DOE EM Performance Agreement:

224-B: Complete draft EECA and submit to regulators - July 2000.

Complete draft SAP and submit to regulators - September 2000. 


\section{ENVIRONMENTAL MANAGEMENT PERFORMANCE REPORT ENVIRONMENTAL RESTORATION \\ APRIL 2000}

\begin{tabular}{|c|c|c|c|c|c|}
\hline \multicolumn{6}{|c|}{ 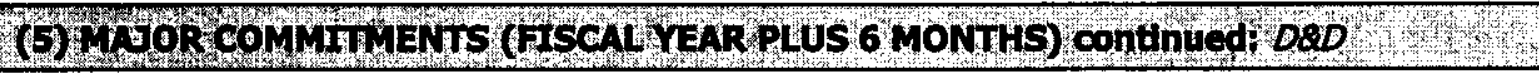 } \\
\hline \multicolumn{6}{|c|}{ - (SC) TPA MIlestones: } \\
\hline Milestone & \multicolumn{3}{|c|}{ Description } & Due Date & $\begin{array}{c}(\mathrm{F}) /(\mathrm{A}) \\
\text { Date }\end{array}$ \\
\hline MPsos & \multicolumn{3}{|c|}{$\begin{array}{l}\text { Issue B Reactor Phase II Feasibility Study Engineering } \\
\text { Design Report for Public Comment }\end{array}$} & $6 / 30 / 00$ & $6 / 30 / 00(F)$ \\
\hline \multicolumn{6}{|c|}{$\begin{array}{l}\text { (SD) DWFSB Commitment: } \\
\text { None identified at this time. }\end{array}$} \\
\hline \multicolumn{6}{|c|}{ 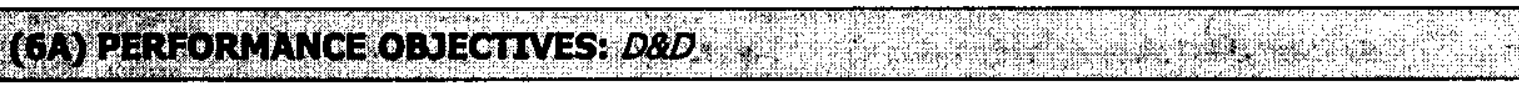 } \\
\hline \multicolumn{2}{|c|}{ Outcome } & Performance Indicator & \multicolumn{3}{|c|}{ Status } \\
\hline \multicolumn{2}{|c|}{$\begin{array}{l}\text { Restoro ahe piver corridor } \\
\text { for whulpleuses }\end{array}$} & $\begin{array}{l}\text { Reactor ISS and preparation of } \\
\text { facilities for decommissioning. }\end{array}$ & \multicolumn{3}{|c|}{$\begin{array}{l}\text { Baseline reactor ISS work is } \\
\text { projected to be completed per PI } \\
\text { requirements. }\end{array}$} \\
\hline \multirow{2}{*}{\multicolumn{2}{|c|}{$\begin{array}{l}\text { Transfion Central Plateau } \\
\text { to Support Long-Term } \\
\text { Waste Management }\end{array}$}} & $\begin{array}{l}\text { Maintain facilities until D\&D } \\
(233-S) \text {. }\end{array}$ & \multicolumn{3}{|c|}{$\begin{array}{l}\text { FYO0 work resequenced via } \\
\text { BCP-20141, approved March } 14, \\
2000 . \text { New performance indicators } \\
\text { TBD. }\end{array}$} \\
\hline & & $\begin{array}{l}\text { Maintain facilities until D\&D } \\
(224-B) \text {. }\end{array}$ & \multicolumn{3}{|c|}{$\begin{array}{l}\text { 224-B baseline work impacted by } \\
\text { inoperable B-Plant exhaust system. } \\
\text { Project is evaluating entry with } \\
\text { appropriate PPE to conduct } \\
\text { required walkdowns. }\end{array}$} \\
\hline
\end{tabular}

\section{Green}

\section{(6B) PERFORMANCE MEASURES: D\&D}

\begin{tabular}{|c|c|c|c|c|}
\hline & $\begin{array}{c}\text { DWP } \\
\text { FY00 }\end{array}$ & $\begin{array}{c}\text { Current Baseline } \\
\text { (Incl. Baseline } \\
\text { Changes) }\end{array}$ & $\begin{array}{c}\text { Forecast } \\
\text { For FY00 }\end{array}$ & $\begin{array}{c}\text { Completed } \\
\text { YTD }\end{array}$ \\
\hline Facilltes & 0 & $4^{*}$ & $4^{*}$ & 3 \\
\hline
\end{tabular}

*116-D, 116-DR, 119-DR and 108-F (Final Report scheduled for September 2000). 


\section{ENVIRONMENTAL MANAGEMENT PERFORMANCE REPORT ENVIRONMENTAL RESTORATION \\ APRIL 2000}

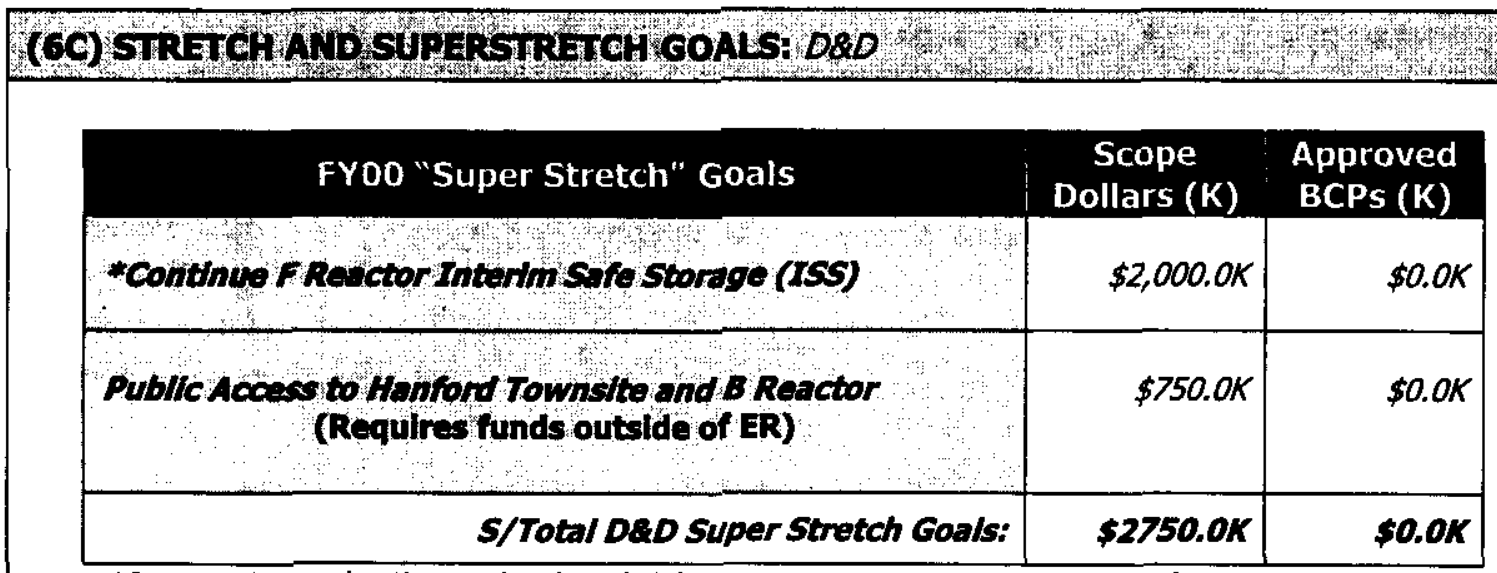

*Status: Plan and estimate developed, BCP in process to execute a portion of superstretch.

\section{(7) PROJECT STATUS (COST/ SCHEDULE/MAUOR BASELTNE CHANGE) PQD}

- (7A) Schedule:

\begin{tabular}{|c|c|c|c|}
\hline \multirow{2}{*}{ Decommissioning Projects } & BCWS & BCWP & Variance \\
\hline & $\$ \mathbf{K}$ & $\$ \mathbf{K}$ & $\$ K$ \\
\hline EROS Deconteminotion a Decommlotonlag & 6422 & 5894 & -528 \\
\hline Total bab & 6422 & 5894 & -528 \\
\hline
\end{tabular}

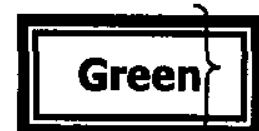

PBS-ER-OS - Decontamination and Decommissioning

Schedule Variance $=[(-\$ 528 K) ;(-8.2 \%)]$ LLast Month: $(-\$ 585 K) ;(-10.8 \%)]$

Cause: 233-S decommissioning delay in removal of roof duct and decon due to replacement of deteriorated glove bag; late receipt of waste containers and CAM equipment at 233-S.

Resolution: Duct removal started in late February was completed in mid-March - will correct variance; procurement will increase in next few months and place purchases back on schedule

Cause: 224-B entry was restricted due to inoperable B-Plant exhaust system.

Resolution: Initiated planning for walkdowns without facility ventilation; expect to achieve entry in late March.

- (7B) Cost:

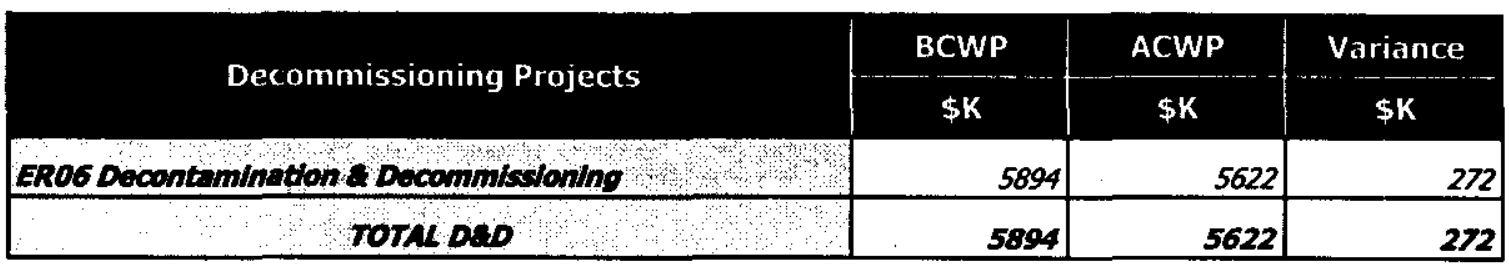

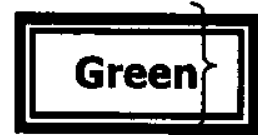

PBS-ER-06 - Decontamination and Decommissioning

Cost Variance $=[+\$ 272 K ;+4.6 \%]$ [Last Month: $+\$ 315 K ;+6.5 \%]$

Cause: ISS general equipment usage less than planned due to dual project usage.

Resolution: Will monitor costs. Savings will be used to perform other remediation work.

Cause: 233-S - Additional cost to correct air flow and installing electrical upgrades in the viewing room; unexpected difficulties resulted in extra cost to remove glovebag from the Laadout Hood area.

Resolution: Cost overruns are being trended. Engineering controls have been implemented to resume characterization activities. 


\section{ENVIRONMENTAL MANAGEMENT PERFORMANCE REPORT ENVIRONMENTAL RESTORATION \\ APRIL 2000}

(8) REGULATORY ISSUES: D\&D

D\&H Reactor Impacts of TPA milestones: The acceleration of the Reactor ISS has gotten out of sync with the current $M-93$ milestones, especially the competitive procurement and renegotiating milestones for $D R, D$, and $H$ at the same level of detail as $F$ and $C$ reactors.

\section{Green}

Status: Initial discussions with the regulators have started which may lead to formal negotiations in the near future. Until that time, EPA is reluctant to support continuing with the next two reactors until the milestones are settled.

(9) EXIERNAL, ISSUES (le. HAB, Congress, etc): DRD

None identified at this time.

\section{(10) DOE RL \& HQ ISSUES/REQUESTS (not covered elsewhere): D\&D}

FYO1 ISS Funding: Partial funding in FYO1, and no funding in FYO2 will result in program suspension and loss of potential cost savings.

Status: Need strategy to maintain critical resources and visible progress; in past two years accelerated progress has been achieved through supplemental congressional funding.

224-B: Entry was restricted due to the inoperable B-Plant exhaust system.

Status: Forecasted repair dates (April 20) indicate that the scheduled completion of the sampling and analysis plan performance incentive (PI) will be impacted.

\section{Yellow}

(11) INTEGRATION ACTIVITIES, D\&D

None identified at this time. 
ENVIRONMENTAL MANAGEMENT PERFORMANCE REPORT

ENVIRONMENTAL RESTORATION

APRIL 2000

\section{Program Management and Support (PM\&S)}




\title{
ENVIRONMENTAL MANAGEMENT PERFORMANCE REPORT ENVIRONMENTAL RESTORATION \\ APRIL 2000
}

\section{SECTION B - RESTORING THE RIVER CORRIDOR}

\author{
Financial data as of month-end February. All other data as of March 23, unless otherwise noted.
}

Program Management \& Support (PM\&S):

\section{(1) ACCOMPLISHMENTSA PM\&S}

Safety \& Health: The design of a cooling garment with an external reservoir was finalized with the manufacturer. A prototype will be shipped to BHI in March. The prototype cooling garment will be part of the protective system to be tested for BHI at the Operating Engineers Technical Center.

Compllance \& Quallty Programs/Price Anderson Amendment Act (PAAA): Conducted an Independent Assessment of the ERC Criticality Safety Program at the request of the RL. The team determined that no imminent nuclear safety hazards exist for the areas assessed. One Corrective Action Request and thirteen observations were identified.

Project Procurement \& Property Management: BHI received notification from the RL Contracting Officer approving BHIs Balanced ScoreCard (BCS) FYOO Plan. The BCS Plan is intended to be the primary method for DOE-RL to assess the performance of BHI's procurement methodology and provide the basis for the continued approval of BHIs purchasing system.

Technology Applications: Accelerated Site Technology Deployment for the F Reactor Fuel Storage Basin cleanout is in final stages of completion and will be submitted to DOE-S\&T in response call for proposal by D\&D Focus Area. Requesting $\$ 750 K$ in DOE-S\&T funds for FYOO and FYO1.

Received notice from the Subsurface Contamination Focus Area that the following Technical Task Plans will be funded for FYO1 under the GWNZ Integration Project: Hydrologic Characterization of the Hanford Vadose Zone at Representative Sites (\$425K); Vadose Zone Monitoring of the Hanford Site Surface Barrier (\$200K). The Principal Investigators for both of these are PNNL personnel.

Environmental Technologies: Completed an assessment of the onsite 222-S Laboratory. The assessment will result in several findings and observations. The findings and observations do not effect the usability of ERC Project data.

Planning \& Controls: The Integrated Project Priority List (IPL) development for the FYO2 Budget submittal was completed. The IPABS database has also been updated with FYO2 PBS data as planned.

Efforts in support of Site planning initiatives continue, with ER support to provide Baseline data, for alternate work prioritization studies initiated by RL.

(2) SAFETY/ISMS/CONDUCT OF OPS. PM\&S

See Cross-Cutting Package.

(3) BREAKTHROUGHS JOPPORTUNITES FOR IMPROVEMENT PMAS

None identified at this time.

(4) LONG-TERM (6 MONTHS PLUS) TMPORTANT TTEMS, PMRS

Planning \& Controls: Mid-Year Review - May 8-9

Detail work planning process for FY01-FY03 - Kick-off meeting - June 2

(5) MAJOR COMMITMENTS (FISCAL YEAR PLUS 6 MONTHS), PM\&S

- (5A) DOE Secretarial:

None identified at this time. 


\section{ENVIRONMENTAL MANAGEMENT PERFORMANCE REPORT ENVIRONMENTAL RESTORATION \\ APRIL 2000}

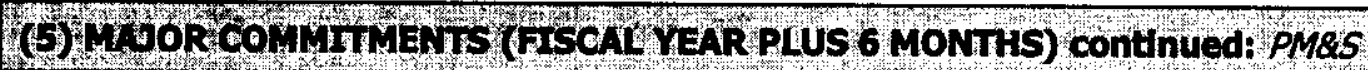

- (5B) DOE EM Performance Agreement:

None identified at this time.

- (5C) TPA Mllestones:

None identified at this time.

- (SD) DNFSB Commitment:

None identified at this time.

(6A) PER FORMANCE OBJECTIVES, PMAS

None identified at this time.

(6B) PERTORMANCE MEASUREST PM\&S

None planned in FYoO.

(6C) STRETCH AND SUPERSTRETCH GOALS, PM\&S

None identified at this time.

(7) PROJECT STATUS (COST/SCHEDULE / MAOOR BASELTNE CHANGE), PMQS

- (7A) Schedule:

\begin{tabular}{|l|r|r|r|}
\hline \multirow{2}{*}{ Program Management \& Support } & \multicolumn{1}{|c|}{ BCWS } & BCWP & Variance \\
\cline { 2 - 4 } & \$K & \$K & \multicolumn{1}{|c|}{$\$ \mathrm{~K}$} \\
\hline ER1O ERC Program Management a support & 7137 & 7134 & -3 \\
\hline ER1O RL Program Managoment \& support & 3099 & 2075 & -1024 \\
\hline TOTAL PMas & 10236 & $\mathbf{9 2 0 9}$ & -1027 \\
\hline
\end{tabular}

PBS-ER-10 - ERC Program Management and Support

Schedule Variance $=[(-\$ 1,027 K) ;(-10.0 \%)]$ [Last Month: $(-\$ 1,724 K) ;(-22.3 \%)]$

Cause: Late billing on site-wide assessments.

Resolution: RL is discussing billing/timing with other site contractors.

- (7B) Cost:

\begin{tabular}{|c|c|c|c|}
\hline Dronga Manaomant \& Sunnont & BCWP & ACWP & Variance \\
\hline 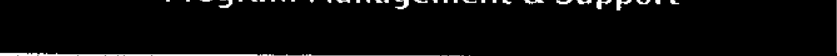 & $\$ \mathbf{k}$ & $\$ \mathbf{K}$ & $\$ \mathbf{K}$ \\
\hline ERIO ERC Progrom Mansoement \& suppoot & 7134 & 7090 & 44 \\
\hline ERIO RL Proorom Monsogenent a support & 2075 & 2075 & 0 \\
\hline rotal pmas & 9209 & 9165 & 4 \\
\hline
\end{tabular}

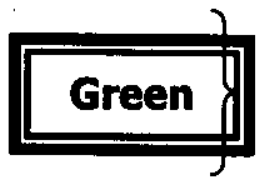

PBS-ER-10 - ERC Program Management and Support

Cost Variance $=[+\$ 44 K ;+0.5 \%]$ [Last Month: $+\$ 16 K,+0.3 \%]$

On Budget.

(8) REGULATORY ISSUES PMAS

None identified at this time. 


\section{ENVIRONMENTAL MANAGEMENT PERFORMANCE REPORT ENVIRONMENTAL RESTORATION \\ APRIL 2000}

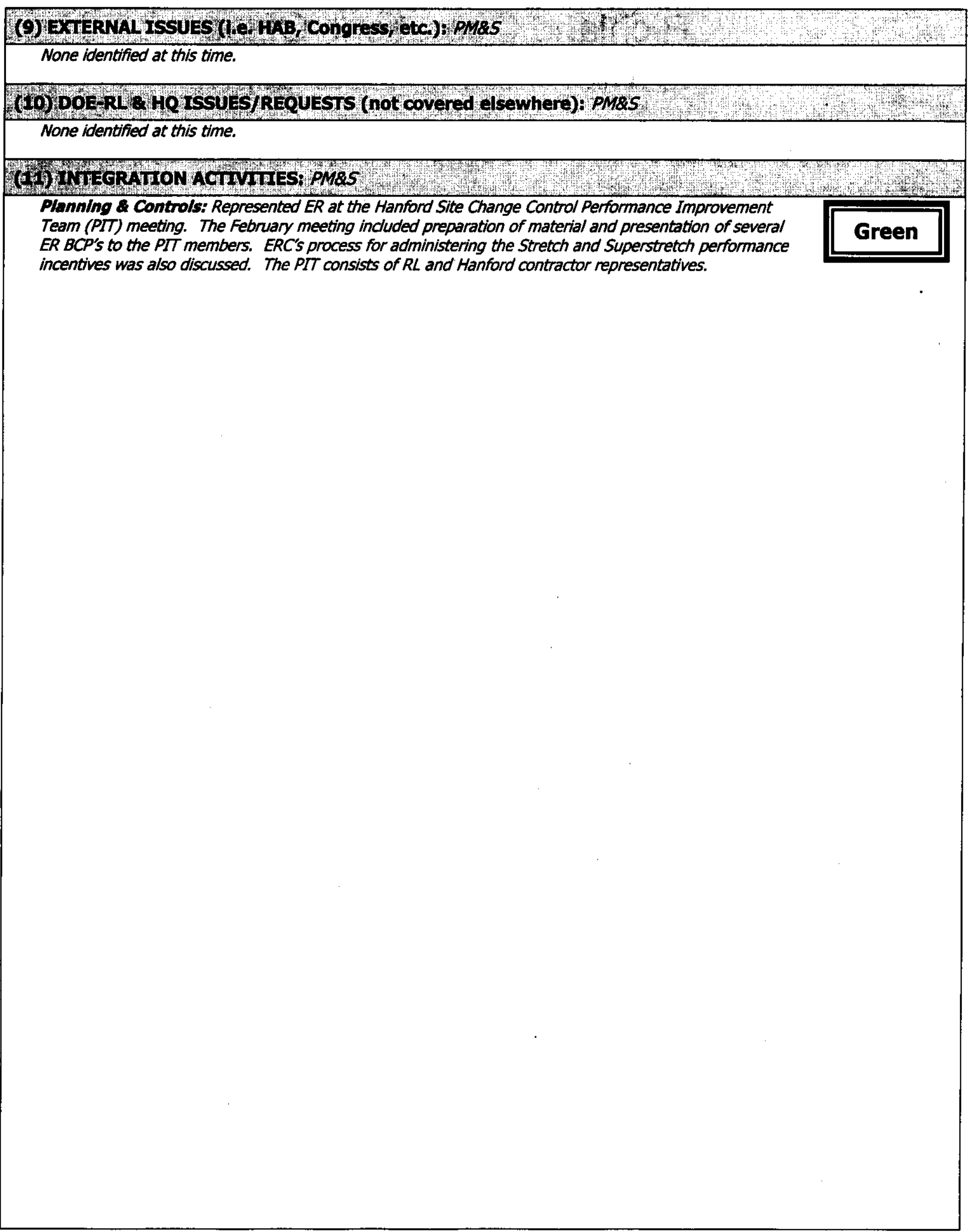




\section{Richland Operations Office Environmental Restoration}

\section{Environmental Management Performance Report}

\section{Section C - Central Plateau Informaticlz}

April 2000

- Groundwater/Vadose Zone Integration Project

- Surveillance / Maintenance \& Transition Projects

Transition the
Central Plateau

\section{Focused on Progress...}

\section{Focused on Outcomes!}

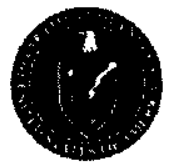

Department of Energy

Richland Operations Office

Bechtel Hanford, Inc.

Environmental Restoration Contractor 


\section{ENVIRONMENTAL MANAGEMENT PERFORMANCE REPORT ENVIRONMENTAL RESTORATION CONTRACT \\ APRIL 2000}

\section{SECTION C - TRANSITIONING THE CENTRAL PLATEAU}

\section{Financial data as of month-end February. All other data as of March 23, unless otherwise noted.}

Groundwater/Vadose Zone Integration (GW/VZ):

\section{(1) I COOMF HSH MENTS, GWNZ}

Long-Term Monitoring: Completed Phase I sampling from 22 wells in support of the 618-11 Burial Ground tritium investigation; tritium results have been received from all wells and results of other constituents from well 699-13-13A have been received. Tritium remains elevated greater than 7 million $p C i / L$ in well 699-13-13A and consistent with the regional plume in other wells (up to $54,400 \mathrm{pCi} / \mathrm{L}$ ).

Well Drilling, Maintenance, and Decommissioning: Completed installation of RCRA GW monitoring wells; completion letter issued (six TPA Milestones M-24-00K, M-24-41 thru M-24-45). Pump and Treat Systems: All groundwater pump and treat systems have operated above planned
availability levels through February.

ISRM Drilling/Injection: Initiated drilling campaign for ISRM; two wells out of sixteen have been drilled to total depth, with one of the two wells completed. (See Item \#4 below for out-year work scope).

Integrated Planning: Conducted the Regulatory Workshop on Cleanup End-points integration of 100 Area Groundwater, Remedial Action, Decontamination \& Decommissioning, and ISS activities. The final report on this waste area will be issued at the end of March, and will contain all the recommendations of the stakeholders, Tribal Nations, regulators, and DOE.

Public Involvement: Prepared two press releases, conducted a media event, and briefed the HAB concerning the 618-11 Burial Ground tritium issue.

(2) SAFETY/ISMS/CONDUCT OF OPS: GW/VZ See Cross-Cutting Package.

(3) BREAKTHROUGHS/OPPORTUNITIES FOR IMPROVEMENT: GW/VZ None identified at this time.

(4) LONG-TERM (6 MONTHS PLUS) IMPORTANT ITEMS continUEd: GW/VZ Key ISRM FY2000 Activities:

EY 2001 Activities: (Planned Activities)

Activities: Drill and install 24 ISRM Barrier Wells. Utilize all wells for ISRM Barrier emplacement.

[Approximately 240 meters of additional ISRM Barrier length to be constructed in FY 2001.]

Drill and install 4 ISRM compliance wells.

FY 2002 Activities: (Planned Activities)

Activities: Drill and install 24 ISRM Barrier Wells. Utilize all remaining wells for ISRM Barrier emplacement.

[Approximately 240 meters of additional ISRM Barrier length to be constructed in FY 2002.]

Demobilize evaporation pond (FY 2002 or FY 2003 Activity).

\section{(5) MAJOR COMMITMENTSE GWNZ}

\section{- (5A) DOE Secretarial:}

None identified at this time. 


\section{ENVIRONMENTAL MANAGEMENT PERFORMANCE REPORT ENVIRONMENTAL RESTORATION CONTRACT \\ APRIL 2000}

(5) M HOR COMMIIMENHS continued GWVZ

- (SB) DOE EM Performance Agreement:

Transmit Update of the Vadose Zone Science and Technology Roadmap (PBS VZO1) due April 30.

Status: Forecasted to be complete by April 28.

Complete Installation of the Wells and Initiate Injection of the Barrier for Phase 2 of the In Situ REDOX Manipulation Project (PBS ERO8) due September 30.

Status: Forecasted to be complete by September 30.

- (5C) TPA Millestones:

\begin{tabular}{|c|c|c|c|}
\hline Milestone & Description & Due Date & $\begin{array}{l}\text { (F)/(A) } \\
\text { Date }\end{array}$ \\
\hline M1922 & $\begin{array}{l}\text { Submit U-Pond/Z-Ditches Cooling Water Group } \\
\text { Work Plan }\end{array}$ & $12 / 31 / 99$ & $12 / 14 / 99(A)$ \\
\hline M-24-00K & 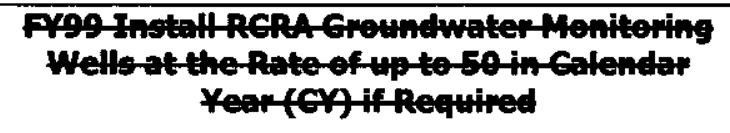 & $2 / 29 / 00$ & $2 / 17 / 00(A)$ \\
\hline$M-24-41$ & $\begin{array}{l}\text { Install Three (3) Additional RCRA Wells for the } \\
\text { SST WMA S-SX }\end{array}$ & $2 / 29 / 00$ & $2 / 17 / 00(A)$ \\
\hline$M-24-42$ & $\begin{array}{l}\text { Install One Replacement Well for the 216-5-10 } \\
\text { Pond }\end{array}$ & $2 / 29 / 00$ & $2 / 17 / 00(A)$ \\
\hline$M-24-43$ & $\begin{array}{l}\text { Install One (1) Additional RCRA Well for the } \\
\text { SST WMA TX-TY }\end{array}$ & $2 / 29 / 00$ & $2 / 17 / 00(A)$ \\
\hline$M-24-44$ & $\begin{array}{l}\text { Install One Replacement Well for the } 216-B-3 \\
\text { Pond *This is an extension of a CERCLA vadose } \\
\text { borehole. }\end{array}$ & $2 / 29 / 00$ & $2 / 17 / 00(A)$ \\
\hline$M-24-45$ & $\begin{array}{l}\text { Install Two (2) Additional RCRA Wells for the } \\
\text { SST WMA B-BX-BY }\end{array}$ & $2 / 29 / 00$ & $2 / 17 / 00(A)$ \\
\hline$M-13-23$ & Submit 200-TW-1 Work Plan & $8 / 31 / 00$ & $8 / 31 / 00(F)$ \\
\hline$M-13-24$ & Submit 200-TW-2 Work Plan & $8 / 31 / 00$ & $8 / 31 / 00(F)$ \\
\hline$M-13-00 K$ & Submit (1) 200 NPL RI/FS (RFI/CMS) Work Plan & $12 / 31 / 00$ & $12 / 31 / 00(F)$ \\
\hline$M-13-25$ & $\begin{array}{l}\text { Submit Uranium Rich Process Waste Group } \\
(200-P W-2) \text { Work Plan }\end{array}$ & $12 / 31 / 00$ & $12 / 31 / 00(F)$ \\
\hline$* M-24-00 L$ & $\begin{array}{l}\text { Install RCRA Groundwater Monitoring Wells at the } \\
\text { Rate of up to } 50 \text { in Calendar Year }(C Y) 2000 \text { if } \\
\text { Required }\end{array}$ & $12 / 31 / 00$ & $12 / 31 / 00(F)$ \\
\hline
\end{tabular}

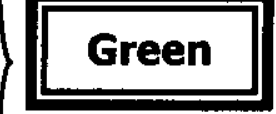

*Ecology and DOE have not agreed on the number of wells. Item is currently in dispute.

- (5D) DNFSB Commitment:

None identified at this time. 


\section{ENVIRONMENTAL MANAGEMENT PERFORMANCE REPORT ENVIRONMENTAL RESTORATION CONTRACT \\ APRIL 2000}

(6A) PEAFORWMW GE OVOEOTVES, GWNZ - (River and PlateaU)

\begin{tabular}{|c|c|c|}
\hline Outcome & Performance Indicator & Status \\
\hline 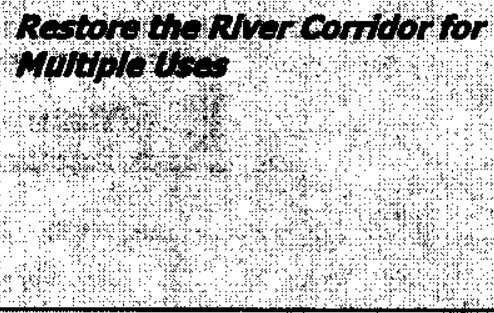 & $\begin{array}{l}\text { Manage groundwater plumes per } \\
\text { interim RODs. }\end{array}$ & $\begin{array}{l}\text { Baseline work is projected to be } \\
\text { completed per PI requirements, } \\
\text { BCP-20065 was submitted and } \\
\text { approved to extend the ISRM } \\
\text { drilling schedule as a result of } \\
\text { late signing of the 100-HR-3 } \\
\text { ROD. }\end{array}$ \\
\hline \multirow{3}{*}{ 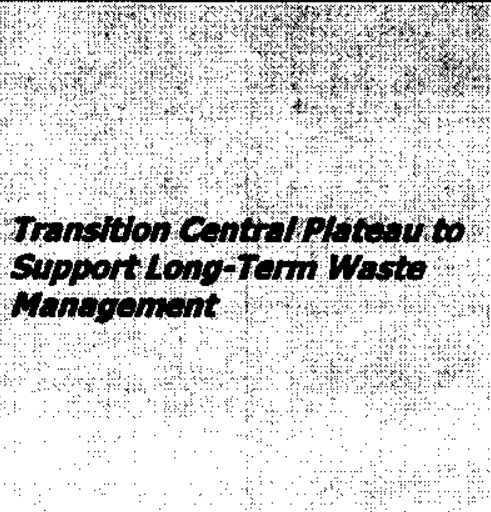 } & $\begin{array}{l}\text { Complete system assessment } \\
\text { capability. }\end{array}$ & $\begin{array}{l}\text { Baseline work projected to be } \\
\text { completed per PI requirements }\end{array}$ \\
\hline & Soil sites assessments. & $\begin{array}{l}\text { Baseline work projected to be } \\
\text { completed per PI requirements. }\end{array}$ \\
\hline & $\begin{array}{l}\text { Manage groundwater plumes per } \\
\text { interim RODs }\end{array}$ & $\begin{array}{l}\text { All measures projected to meet } \\
\text { PI requirements; all baseline } \\
\text { work projected to be completed } \\
\text { per PI requirements. }\end{array}$ \\
\hline
\end{tabular}

(6B) PERFORMANCE MEASURES: GW/Z

None planned in FYOO.

(6C) STRETCH AND SUPERSTRETCH GOALS, GWNZ

\begin{tabular}{|c|r|r|}
\hline FY00 "Stretch" Goals & $\begin{array}{c}\text { Scope } \\
\text { Dollars } \\
\text { (K) }\end{array}$ & \multicolumn{1}{|c|}{$\begin{array}{c}\text { Approve } \\
\text { d BCPS } \\
\text { (K) }\end{array}$} \\
\hline $\begin{array}{r}\text { Groundwater Management - Resin Purchased } \\
\text { (1) Resin Purchase (BCP-20115) }\end{array}$ & $\$ 406.6 \mathrm{~K}$ & $\$ 406.6 \mathrm{~K}$ \\
\hline $\begin{array}{l}\text { Complete Partitioning of Interwell Treatment at 200-2P-1 } \\
\text { and 200-ZP-2 }\end{array}$ & $\$ 299.4 \mathrm{~K}$ & $\$ 0.0 \mathrm{~K}$ \\
\hline S/Total GW-Vadose Zone Stretch Goals: & $\$ 706.0 \mathrm{~K}$ & $\$ 406.6 \mathrm{~K}$ \\
\hline
\end{tabular}

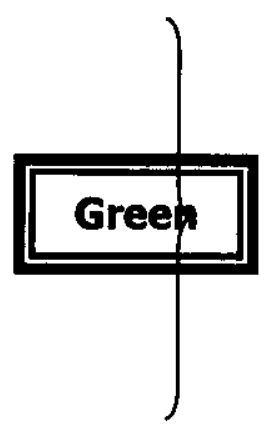




\section{ENVIRONMENTAL MANAGEMENT PERFORMANCE REPORT ENVIRONMENTAL RESTORATION CONTRACT \\ APRIL 2000}

\section{(6C) STRFT CH AND SUPERSTRET CH COALS continued; GW/VZ}

\begin{tabular}{|c|c|c|}
\hline FY00 "Super Stretch" Goals & $\begin{array}{c}\text { Scope } \\
\text { Dollars (K) }\end{array}$ & $\begin{array}{l}\text { Approved } \\
\text { BCPs (K) }\end{array}$ \\
\hline $\begin{array}{l}\text { Provide Permanent solution for Hanford Groundwater } \\
\text { Plumes }\end{array}$ & $\$ 750.0 K$ & $\$ 0.0 K$ \\
\hline $\begin{array}{l}\text { Complete Remediation of } 60 \text { sq. Ml of Hanford sites } \\
\text { (1) Verify and administratively close } 170 \text { wells } \\
\text { (2) Decommissioning of } 200 \text { wells }\end{array}$ & $\$ 450.0 K$ & $\begin{array}{l}\$ 0.0 K \\
\$ 0.0 K\end{array}$ \\
\hline S/Total GW - Vadose Zone Super Stretch Goals: & $\$ 2,100.0 K$ & $\$ 0.0 K$ \\
\hline
\end{tabular}

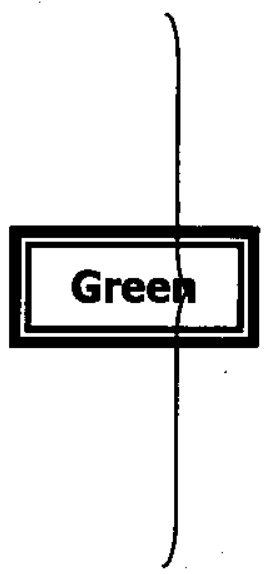

Status: Plan and estimate developed, current work efforts focusing on stretch activities at this time.

\section{(7) PROJECT STATUS (COST/SCHEDULE/MAOOR BASELINE CHANGE), GWNZ}

- (7A) Schedule:

\begin{tabular}{|c|c|c|c|}
\hline \multirow{2}{*}{ Groundwater Vadose Zone Integration } & BCWS & BCWP & Variance \\
\hline & $\$ \mathbf{K}$ & $\$ K$ & $\$ \mathbf{K}$ \\
\hline ERO2 200 Aroa Remodtol Actions & 2896 & 2785 & -111 \\
\hline EROS Groundwaber Management & 10160 & 8136 & .2024 \\
\hline VZOL Groundwater/Vadose Zone & 4503 & 3692 & -811 \\
\hline Wh TOTAL Groundwater & 17559 & 14613 & -2946 \\
\hline
\end{tabular}

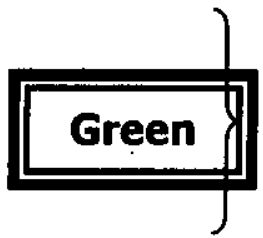

PBS-ER-02 - 200 Area Remedial Action (Assessment)

Schedule Variance $=[(-\$ 111 K) ;(-3.8 \%)]$ [Last Month: $+\$ 1.20 K ;+4.7 \%]$

Cause: Miscellaneous assessment work rescheduled.

Resolution: None required.

PBS-ER-08 - Groundwater Management

Schedule Variance $=[(-\$ 2024 K) ;(-19.9 \%)]$ [Last Month: $(-\$ 1236 K) ;(-16.1 \%)]$

Cause: Groundwater Monitoring sample collection and analysis (PNNL) fell behind schedule in October/November, due to difficulties in obtaining NCO bargaining unit personnel, and has not yet recovered.

Resolution: Additional NCOs have been added and a recovery schedule implemented; unexpected sampling at the 618-11 Burial Ground will impact recovery timing; full recovery is not expected before summer.

Cause: Waste shipments and regeneration at Pump and Treat units have been delayed due to equipment availability problems; no significant impact.

Resolution: Waste shipments have been scheduled through Fluor Hanford.

Cause: 100-HR-3 delay in shipment of waste to ERDF, resin regeneration, and ISRM subcontract activities.

Resolution: Waste shipments have been scheduled through FHI and resin purchase delays will be recovered in spring. 


\section{ENVIRONMENTAL MANAGEMENT PERFORMANCE REPORT ENVIRONMENTAL RESTORATION CONTRACT APRIL 2000}

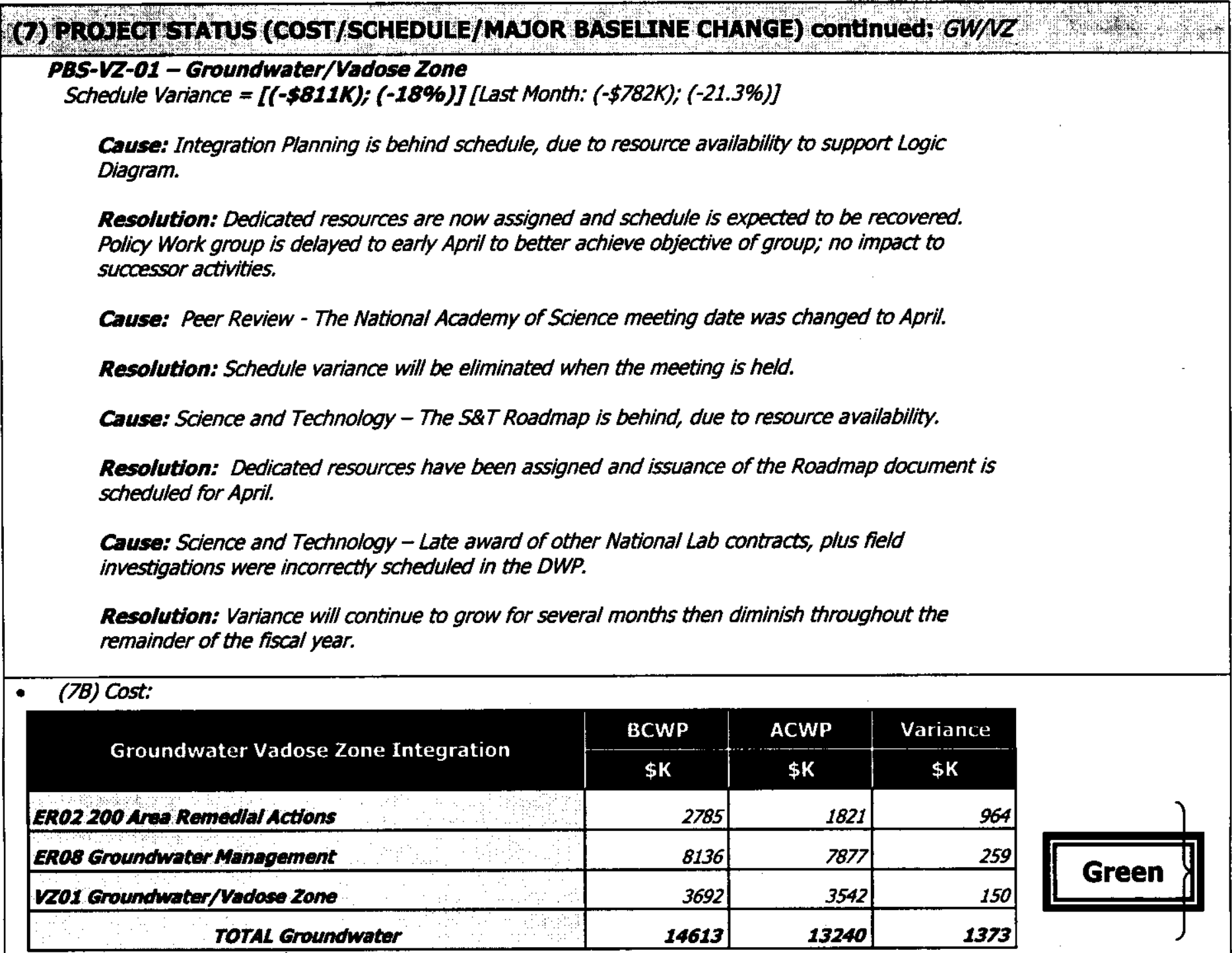

PBS-ER-02 - 200 Area Remedial Action (Assessment)

Cost Variance $=[+\$ 964 K ;+34.6 \%$ ] [Last Month: $+\$ 1046 K ;+39.1 \%$ ]

Cause: Borehole drilling was combined with RCRA drilling resulting in cost savings; efficiencies learned in prior work were applied to Gable Mountain and B-Pond test pit trenching, resulting in savings; number of samples required was reduced.

Resolution: Savings will be used to perform other remediation work.

PBS-ER-08 - Groundwater Management

Cost Variance $=[+\$ 259 K ;+3.2 \%]$ [Last Month: $+\$ 327 K ;+5.1 \%]$

Cause: Fewer support personnel were required than planned.

Resolution: Savings will be used to perform other remediation work.

PBS-VZ-01 - Groundwater/Vadose Zone

Cost Variance $=[+\$ 150 K ;+4.1 \%$ ] [Last Month: $+\$ 484 K ;+16.7 \%$ ]

Cause: Costs of system assessment capability development less than planned.

Resolution: Savings will be used to perform other remediation work. 


\section{ENVIRONMENTAL MANAGEMENT PERFORMANCE REPORT ENVIRONMENTAL RESTORATION CONTRACT \\ APRIL 2000}

(8) REGULATORY ISSUES, GWVZ

200-ZP-2: Regulatory agencies desire continued operation of the 200-ZP-2 vapor extraction unit (not included in DWP).

Status: Project personnel met with EPA (Doug Sherwood), to discuss the need to restart ZP-2 pending completion of the cost estimate to perform the Portitioning Interwell Tracer Test (PIT) test. Decision to be made to either restart ZP-2 or initiate the PITT test by June 1. PIIT test estimate will be completed by the end of March, with management review to be completed by mid April. $A$ BCP for $Z P-2$ restart has also been completed.

200-UP-1: Regulatory agencies desire continued operation of the 200-UP-1 pump and treat system (not included in DWP).

Status: BHI received direction from the Contracting Officer Representative (COR) to extend operations until the end of FYOO. The Groundwater Project will also include operations of UP-1 per FY01-FY03 DWP. A trend has been signed by the COR and a BCP prepared.

200 Area RI/FS: Approximately 700 soil contaminated sites (200 Area) grouped into 23 process-based operable units are to be characterized by year 2008 and remediated by 2018. Currently, no out-year funding exists beginning in FY01. Long-term, RL must decide its budgetary position toward assessment and cleanup of the 200 Area liquid sites. The Regulator position is to submit TPA change packages for each operable unit work plan for enforceability in completing the RI through ROD based on existing TPA milestones.

Status: DOE has prepared a TPA change package for the 200-CW-1 operable unit containing RI/FS milestones for FYOO only. In addition, DOE is currently working on a long-term strategy for prioritizing the 200 Area assessment and remediation activities in conjunction with other site cleanup decisions. BHI has developed a proposal for inclusion of all interim milestones with "TBD" dates for out year milestones.

Waste Control Plan: The Waste Control Plan (WCP) for well services is being revoked by Ecology, and the WCP requirement for signature by the EPA has been questioned.

Status: EPA and Ecology provided a letter which allows the continued storage of waste at the Biosite in 200 West. ER continues to work with the regulators to determine the final disposition of the Biosite waste and storage and disposition of newly generated waste.

Resin Regeneration: Off-Site Resin Regeneration on hold. (U.S. Filter Violations - 7 total.)

Status: Vendor recently inspected, violations identified, and Enforcement Conference completed on March 15. EPA CERCLA off-site authorization to use facility is in question pending resolution of issues.

Well Installation: RL provide funds for $C \gamma-2000 \mathrm{GW}$ Well installation. (Tracked as an issue prior to November.)

Status: Ecology and DOE have not agreed on the number of wells. Item in dispute. BCP to be submitted once scope is defined. Note: This is a TPA milestone that needs to be completed by December 31.

Monitoring Wells: A high tritium value was identified in a monitoring well for the $618-11$ Burial Ground.

Status: The tritium investigation is divided into two phases. Phase I is the initial sampling of existing wells in the area for tritium and other constituents of interest. Phase II is the further characterization of the tritium in the groundwater near the 618-11 Burial Ground.

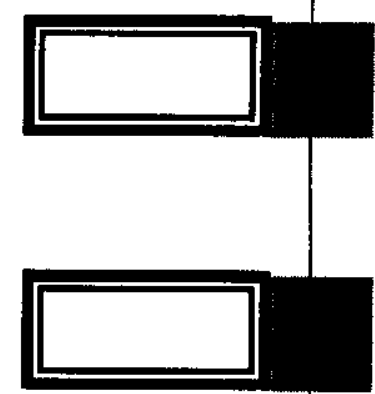

\section{Yellow}
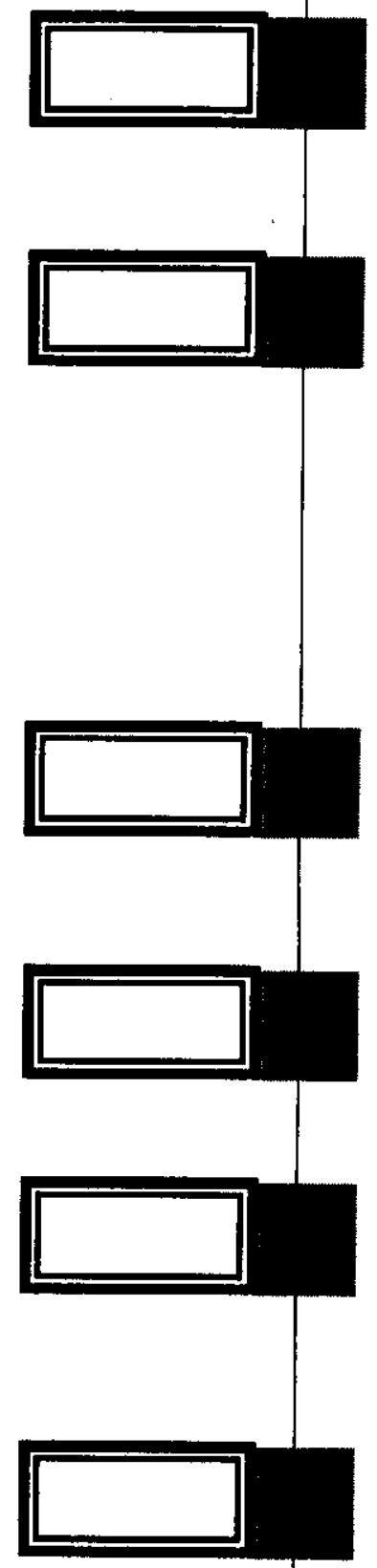


\section{ENVIRONMENTAL MANAGEMENT PERFORMANCE REPORT ENVIRONMENTAL RESTORATION CONTRACT APRIL 2000}

\section{(8) REGULATORY ISSUES continued: GWVZ}

Phase I: The data evaluation of the Phase I sampling event is currently underway. A letter report that will assist in the Phase II plan is currently being prepared. A briefing on the critique of reporting and the Phase 1 results were presented at the HAB ER committee meeting on March 14. This presentation was well received and questions centered around the "trip wires" for reporting, understanding the hydrogeology near the waste site, and blending Phase I and II results with remediation plans.

Phase II: The DQO for Phase II planning is underway as well.

Waste Handlling Losue: On February 24, BHI determined that Comprehensive Environmental Response, Compensation, and Liability ACt (CERCLA) non-radioactive miscellaneous solid waste (MSW) had been inadvertently transported off the Hanford Site and disposed in landfills.

This MSW was generated during groundwater well sampling, groundwater well maintenance, groundwater well drilling and groundwater level measurements. The MSW consists of items such as wipes, surgical gloves, 5 micron filters, stickers, and tape. Some of this MSW is deposited in site dumpsters. The dumpsters are then emptied by another site contractor and transported to a local offsite landfill. This disposal practice has been in effect for several years.

At issue is that some of the MSW may have contacted 200 West Area groundwater that is managed as F001 (carbon tetrachloride) listed waste and 100-N Area groundwater which is managed as F003 (may contain methanol) listed waste. By definition, any material that comes in contact with listed waste can also be considered listed.

The groundwater in the 200 West Area contains low levels of carbon tetrachloride that is a volatile organic. It is expected that little or no carbon tetrachloride would be present in the MSW when it was shipped offsite. Methanol has not been detected in $100 \mathrm{~N}$ Area groundwater; therefore, it is expected that methanol would not be present in the MSW.

The landfills, other contractors and subcontractors have been notified. The EPA and the WA Dept of Ecology were briefed on Thursday February 24.

Status: The offsite shipment of materials potentially containing listed waste continues to be tracked. Corrective actions were taken in mid February to eliminate the possibility for releasing materials containing listed waste from the groundwater services operations. An occurrence report was prepared and the appropriate agencies and vendors were notified. Worst case samples were taken to determine if the materials shipped offsite contained any detachable listed waste. Initial results indicate that the listed waste exists at very low levels immediately after the sampling but was not detachable within 24 hours. Additional results are expected back this week. After the complete results are received, a summary report will be prepared and provided to all parties involved.

(9) EXTERNAL ISSUES (l.e. HAB, Congress, etc) $G W W Z$ None identified at this time.

(10) DOE-RL \& HQ ISSUES/REQUESTS (not covered elsewhere) GWVZ

None identified at this time. 


\section{Surveillance/Maintenance and Transition Project (SM\&T)}




\section{ENVIRONMENTAL MANAGEMENT PERFORMANCE REPORT ENVIRONMENTAL RESTORATION CONTRACT APRIL 2000}

\section{SECTION C - TRANSITIONING THE CENTRAL PLATEAU}

\section{Financial data as of month-end February. All other data as of March 23, unless otherwise noted.}

\section{Surveillance/Maintenance \& Transition Project (SM\&T):}

(1) ACCOMPLISHMENTS: SM\&T

105-KE Reactor: Continued to collect and stage legacy waste for shipping from 105-KE reactor.

Removal is approximately $60 \%$ complete and three ERDF containers have been loaded, one has been

shipped. Began to collect and stage legacy waste for shipping from 105-KW reactor.

183-N Water Treatment Plant: Continued to review the final design package for the new water plant; subcontractor has begun the installation of the new piping system; and phase I deactivation of the existing water plant was initiated (Stretch Goal).

CDI: Completed the Non-Destructive Evaluation (NDE) of crane drum at 221-U canyon (CDI) and issued the final report.

(2) SAFETY/ISMS/CONDUCT OF OPS: SMQT

See Cross-Cutting Package.

(3) BREAKTHROUGHS/OPORTUNITIES FOR IMPROVEMENT SM\&T

None identified at this time.

(4) LONG-TERM (6 MONTHS PLUS) IMPORTANT TTEMS: SM\&T

None identified at this time.

(5) MAJOR COMMITMENTS: SM\&T

- (5A) DOE Secretariall

None identified at this time.

- (5B) DOE EM Performance Agreement:

None identified at this time.

- (5C) TPA Milestones:

None identified at this time.

- (5D) DNFSB Commitment:

None identified at this time. 


\section{ENVIRONMENTAL MANAGEMENT PERFORMANCE REPORT ENVIRONMENTAL RESTORATION CONTRACT APRIL 2000}

\section{(6A) PERFORMANCE OBDECIVEST SMRT}

\begin{tabular}{|c|c|c|}
\hline Outcome & Performance Indicator & Status \\
\hline 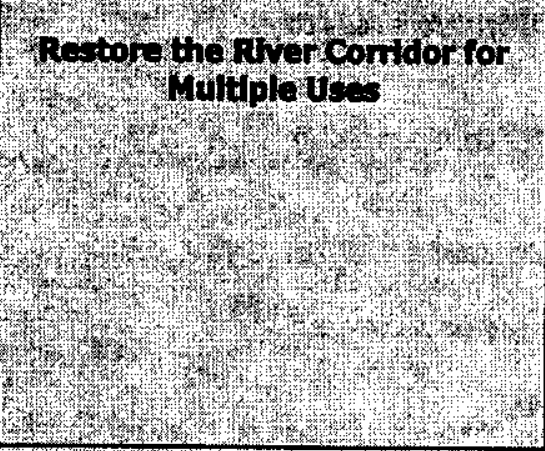 & $\begin{array}{l}\text { Deactivation and preparation } \\
\text { for decommission. }\end{array}$ & $\begin{array}{l}\text { KE/KW legacy waste removal } \\
\text { behind schedule due to } \\
\text { additional regulatory } \\
\text { requirements and resource } \\
\text { allocation (RCT'S/manual). } \\
\text { BCP-20075 approved to extend } \\
\text { schedule by three weeks. } \\
\text { Baseline work is projected to } \\
\text { be completed per PI } \\
\text { requirements. }\end{array}$ \\
\hline 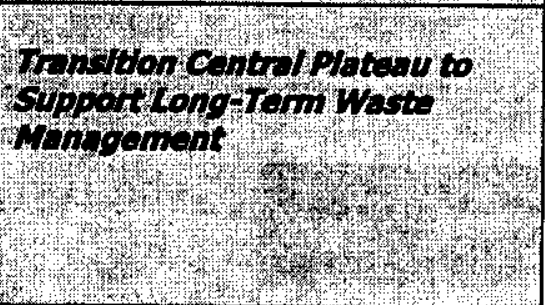 & $\begin{array}{l}\text { Perform S\&M/risk reduction on } \\
\text { inactive facilities to } \\
\text { eliminate/stabilize } \\
\text { environmental, human health } \\
\text { hazards until D\&D; Perform } \\
\text { CDI activities. }\end{array}$ & $\begin{array}{l}\text { CDI baseline work projected to } \\
\text { be completed per PI } \\
\text { requirements. DOE-Waste } \\
\text { Management funding shortfalls } \\
\text { will require scope adjustment. }\end{array}$ \\
\hline
\end{tabular}

(6B) PERFORMANCE MEASURES: SM\&T

None planned in FYOO.

(6C) STRETCH AND SUPERSTRETCH GOALS, SM\&T

\begin{tabular}{|c|c|c|}
\hline FYO0 "Stretch" Goals & $\begin{array}{l}\text { Scope } \\
\text { Dollars } \\
\text { (K) }\end{array}$ & $\begin{array}{l}\text { Approve } \\
\text { d BCPs } \\
\text { (K) }\end{array}$ \\
\hline Deactlvate 183-N water Treatment Plant & $\$ 131.0 K$ & $\$ 131.0 K$ \\
\hline Asbestas Abstement \& Repa/rs (100, 200, a 300 Areas) & $\$ 494.0 K$ & $\$ 0.0 K$ \\
\hline $\begin{array}{l}\text { Complete the cDI Technical Work to support the phase II } \\
\text { Feaslbillty Study }\end{array}$ & $\$ 625.0 K$ & $\$ 0.0 K$ \\
\hline S/Total SM\&T - Facillity Transition Stretch Goals: & $\$ 625.0 K$ & $\$ 131.0 K$ \\
\hline
\end{tabular}

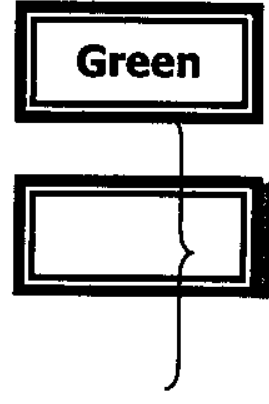

\section{(7) PROJECT STATUS (COST/SCHEDULETMAOR BASEHTE CHANGE) SMQT}

- (7A) Schedule:

\begin{tabular}{|c|c|c|c|}
\hline Surveillance/Maintenance \& Trancition Droinct & BCWS & BCWP & Variance \\
\hline & $\$ K$ & $\$ K$ & $\$ K$ \\
\hline 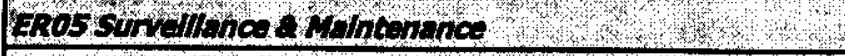 & 5257 & 4759 & -498 \\
\hline 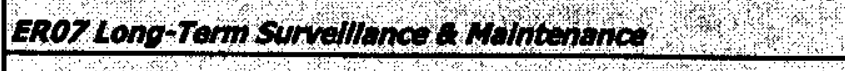 & 3 & 3 & $\underline{0}$ \\
\hline rothL Swat K & 5260 & 4762 & -498 \\
\hline
\end{tabular}

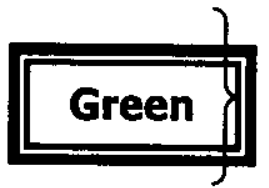




\section{ENVIRONMENTAL MANAGEMENT PERFORMANCE REPORT ENVIRONMENTAL RESTORATION CONTRACT \\ APRIL 2000}

\begin{tabular}{|c|c|c|c|c|}
\hline \multicolumn{5}{|c|}{$\begin{array}{l}\text { PBS-ER-05 - Surveillance and Maintenance } \\
\text { Schedule Varlance }=[(-\$ 498 K) ;(-9.5 \%)][\text { Last Month: }(-\$ 329 K) ;(-7.7 \%)]\end{array}$} \\
\hline \multicolumn{5}{|c|}{$\begin{array}{l}\text { Cause: Preparation and submittal of an unplanned Waste Management Plan to Regulators for } 105- \\
\text { KE legacy waste removal delayed start of field activities. }\end{array}$} \\
\hline \multicolumn{5}{|c|}{$\begin{array}{l}\text { Resolution: The Waste Management Plan has been completed, and field activities commenced in } \\
\text { late December; additional craft resources were added to help recover schedule. }\end{array}$} \\
\hline \multicolumn{5}{|c|}{ Cause: CDI process cell access work delayed due to canyon crane being down for repairs. } \\
\hline \multicolumn{5}{|c|}{ Resolution: Crane NDE completed - recommendations implemented; schedule will be recovered. } \\
\hline \multirow{2}{*}{\multicolumn{5}{|c|}{$\begin{array}{l}\text { PBS-ER-07 - Long-Term Surveillance and Maintenance (BCWS } \$ 47 K \text { for FYO0) } \\
\text { Schedule Variance = N/A }\end{array}$}} \\
\hline & & & & \\
\hline \multicolumn{5}{|l|}{ - (7B) Cost: } \\
\hline \multirow[b]{2}{*}{ Surveillance/Maintenance \& Transition Project } & BCWP & ACWP & Variance & \\
\hline & & $\$ \mathbf{K}$ & & \\
\hline EROS survelliance E Whinterance & 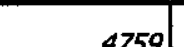 & $4020 \mathrm{l}$ & 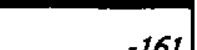 & \\
\hline 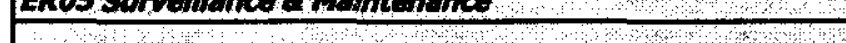 & $4 / 394$ & 49201 & -101 & \\
\hline EROT Long-Term Survelliance \& Maintenenos & 3 & 11 & -8 & Green \\
\hline TOTAL sMat & 4762 & 4931 & -169 & \\
\hline
\end{tabular}

PBS-ER-05 - Survelllance and Maintenance

Cost Variance $=[(-\$ 161 \mathrm{~K}) ;(-3.4 \%)]$ [Last Month: $(-\$ 30 \mathrm{~K}) ;(-0.8 \%)]$

Cause: Canyon crane NDE testing and repair not anticipated; PUREX shotcreting and roof inspections were unanticipated work.

Resolution: $B C P$ approved for NDE testing; roof repair work trended.

(8) REGULATORY ISSUES: SM\&T

None identified at this time.

(9) EXTERNAL ISSUES (1.e. HAB, Congress, etc) I SMAT

None identified at this time.

\section{(10) DOE-RL \& HQ ISSUES/REQUESTS (not covered elsewhere), SMRT}

B-Plant/Purex Roof Funding: Ensure funding is provided by Transition Projects per MOUs, to support roof repair commitments for B-Plant and Purex. Facilities have transitioned to ER with the commitment to fund these repairs from the releasing Project.

Status: Funding for roof repairs have not been included within the current above-the-line Integrated Priority Lists (IPL) targets.

Stack Ventilation: Problems with stack ventilation, retired filters, and other issues documented in letter, M. C. Hughes to R. Gerton, 9/28/99, "Remaining Issues for the Transition of the B-Plant Facility from DOE-Transition to ER"

Status: Facility transferred to ERC September 30, 1999. MOA with open items assigned cost/schedule responsibility received September 30. Original MOA schedule not met. Test ran and in less than 24 hours, new cracks appeared. Filter changeout work near completion. New estimate for ventilation repair being developed. Analysis group review is currently forecasted for April 15. Regulator has been advised that the "New Date" for restoration of ventilation is now April 15. 


\section{ENVIRONMENTAL MANAGEMENT PERFORMANCE REPORT ENVIRONMENTAL RESTORATION CONTRACT APRIL 2000}

(10) DOE-RL \& HQ ISSUES/REQUESTS (not covered elsewhere) continued, SM\&T

B Reactor Duct Removal: State Historical Preservation Office (SHPO) approval of the B reactor duct removal work will not meet our current schedule.

Status: $A$ BCP was submitted to delete the duct removal work scope from the baseline. A separate $B C P$ will be prepared to perform an engineering analysis to seal the roof where the duct is left in place as requested by RL. (Possibly Fr2001 work.)

CDI Funding: DOE-Waste Management has indicated that funding (\$400K) will not be available for the CDI in FYOO. DOE-S\&T additional funding $(\$ 700 \mathrm{~K})$ is also in question.

Green

Status: The $\$ 400 K$ that was planned from Waste Management has been BCP'd by ER to manage this shortfall. The remaining $\$ 350 K$ from DOE-S\&T was included in the March FIN Plan and should be available by the end of March.

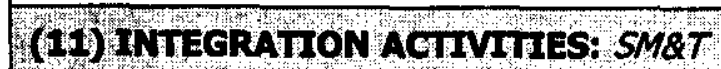

None identified at this time. 


\section{PNNL \\ Environmental Management Performance Report}

Monthly Report - February 2000

April 2000

PREPARED FOR THE U.S. DEPARTMENT OF ENERGY, RICHLAND OPERATIONS OFFICE OFFICE OF ENVIRONMENTAL MANAGEMENT

Pacific Northwest National Laboratory

Operated for the U.S. Department of Energy by Battelle Memorial Institute 


\section{Table of Contents}

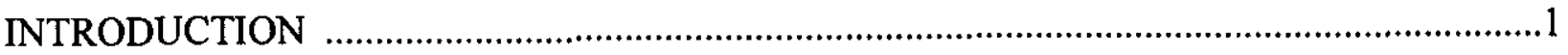

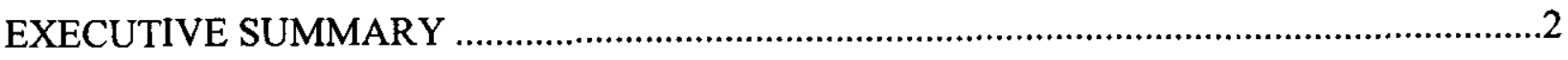

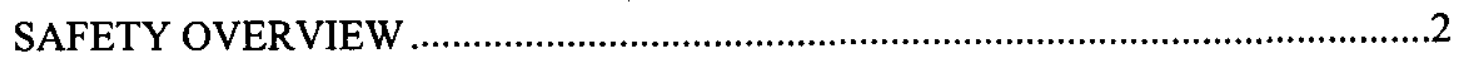

COST/SCHEDULE PERFORMANCE STOPLIGHT ......................................4

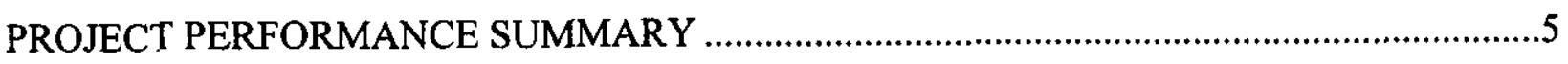

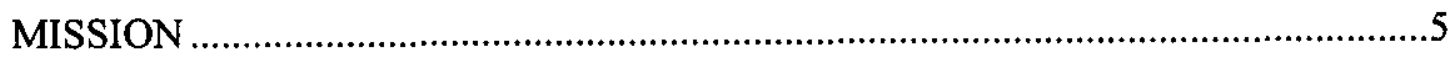

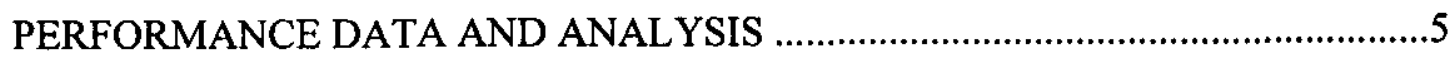


$T$ his document provides the Department of Energy Richland Operations Office (DOE-RL) with a report of the Pacific Northwest National Laboratory (PNNL) performance by Battelle Memorial Institute and its subcontractors.

In Section A, the Executive Summary, text and graphics report the safety metrics status for all PNNL activities. Senior management's overall performance assessment of all Environmental Management activities conducted at PNNL is presented in a stoplight chart.

Section B, Project Performance Summary, provides a brief summary of the month's performance for the PNNL lead activity, PNNL Waste Management (PBS RL-ST01). Summary analyses pertaining to PNNL's support to other Project Baseline Summaries (PBSs) are addressed in the contractor's report having lead responsibility for that scope.

Unless otherwise noted, information in this report is current as of February 27, 2000. 
This section provides an executive-level summary of performance information and is intended to bring to Management's attention that information considered to be most noteworthy. The section begins with overviews of safety, followed by a stoplight chart on overall performance.

\section{Safety Overview}

$\mathrm{T}$ The focus of this section is on documenting trends in work-related injuries and illnesses.

Improvements in these rates result from the efforts of the PNNL workforce as they implement the Integrated Environment, Safety, and Health (ES\&H) Management System (ISMS), work towards achieving Voluntary Protection Program (VPP) "star" status, and accomplish work through Enhanced Work Planning (EWP). Safety and health statistical data are presented in this section.

\section{Significant Safety and Health Events}

Currently the PNNL Total Recordable Case Incidence Rates appear to be cycling periodically around the 2.22 baseline average and show no significant deviations from the average. The Lost Workday Case Incidence Rates demonstrate that, for eight of the past nine months, the rates have been below the 0.98 average. No notable changes have occurred in the Lost Workday Severity Rates since the last report.

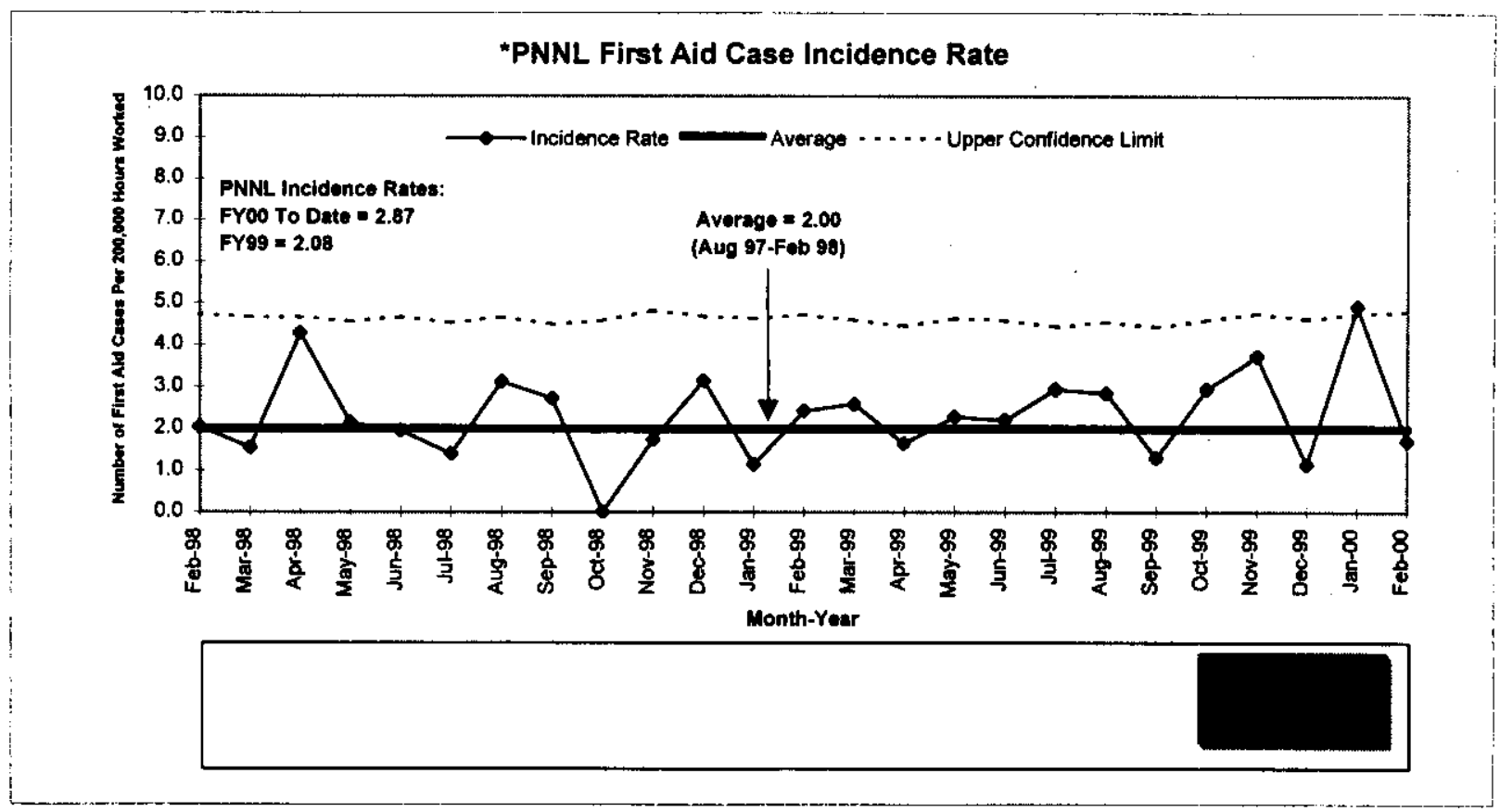



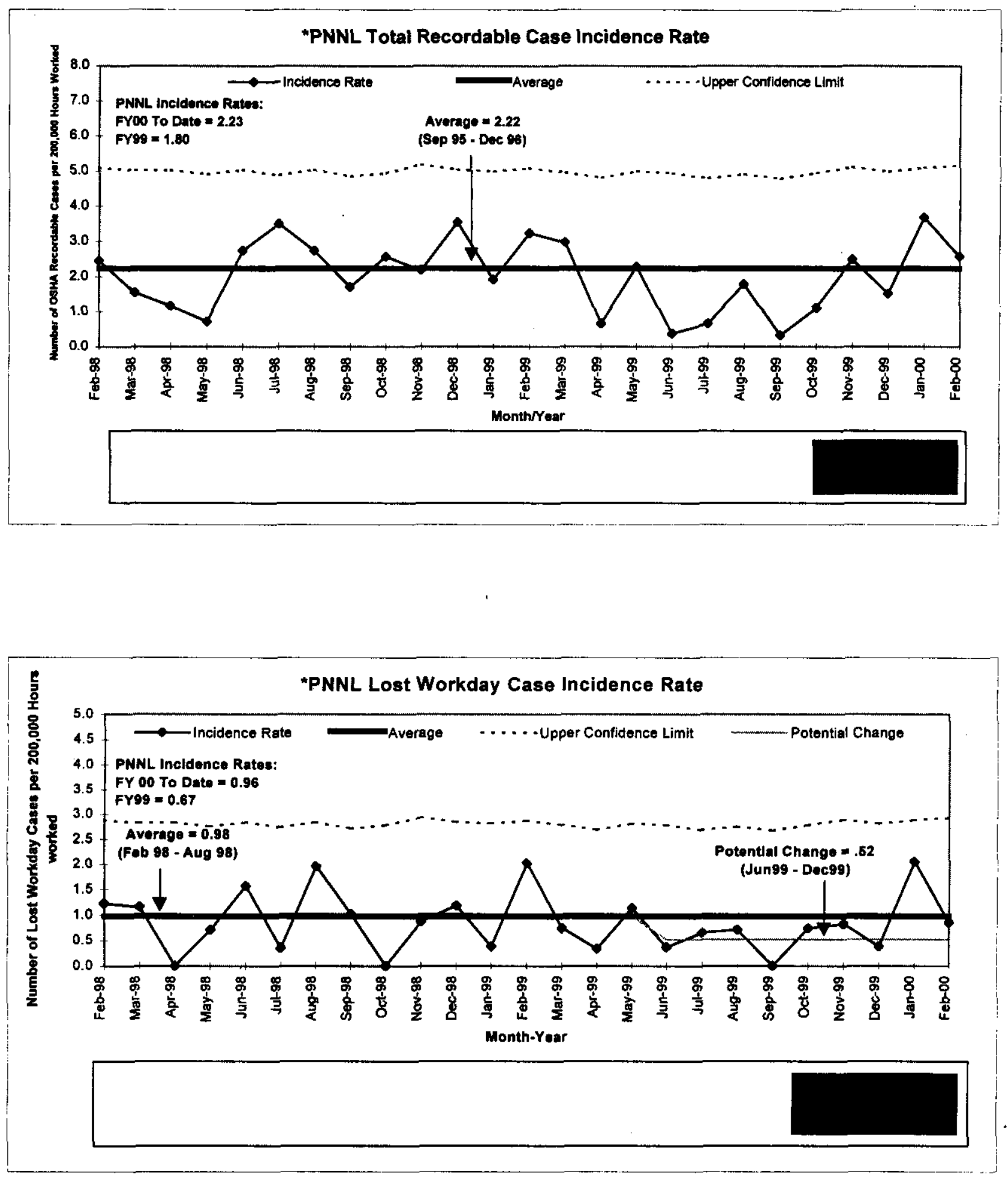


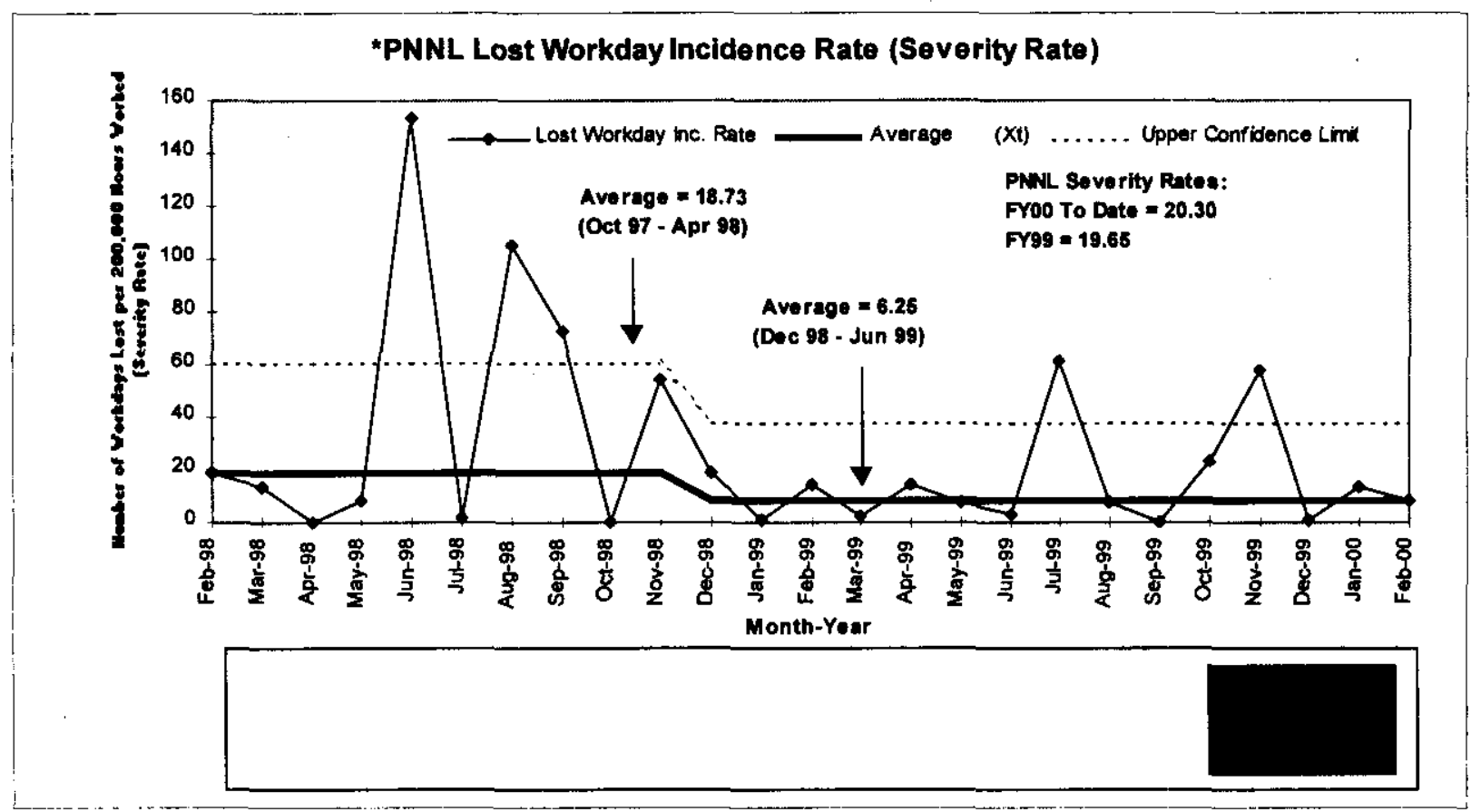

\section{Cost/Schedule Performance Stoplight}

The following rating reflects overall performance for activities conducted by PNNL. (Narrative not required when rating is green.)

Green: Satisfactory

Yellow: Significant improvement required

Red: Unsatisfactory 
This section provides cost and schedule performance, any significant issues, and upcoming baseline change requests for the period covered. In fiscal year (FY) 2000, Battelle Memorial Institute has lead responsibility over PBS RL-ST01, PNNL Waste Management WBS 1.7.1.

\section{Mission}

WBS 1.7.1 provides PNNL with waste management services and compliant operations in support of science and technology development for the multiprogram needs of the U.S. Department of Energy (DOE) Complex. These services include:

- essential surveillance and maintenance of DOE laboratory facilities assigned to PNNL for safe containment of radioactive and hazardous materials

- infrastructure required to manage wastes and effluents currently generated at the PNNL

- operational compliance services to meet regulatory requirements and operating permits including environment, safety, and health regulations

- management of legacy wastes and contamination remaining from past PNNL research operations.

\section{Performance Data and Analysis}

As of February 27 , the cumulative cost of $\$ 4.9$ million and a positive cost variance of $\$ 0.4 \mathrm{M}$ results from reduced overhead rates and delayed billings. A change request is in process to revise the basis of estimate and align budget and funds. It is expected that the baseline activities will be completed within the funding allocation. The primary reasons for the cumulative schedule variance of negative $\$ 0.4 \mathrm{M}$ are described below:

- Difficulties in completing the high-dose waste container design delayed the initiation of the fabrication of the drum-handling system. The design of the shielded drums is being subjected to significant review as part of the safety analysis report for packaging (SARP). The primary container design failed the structural analysis simulating a drop test. Staff members determined that the inner shipping container would not meet the 4-foot drop scenario imposed by the SARP. Redesign of the inner container corrected the deficiency. The SARP is about $40 \%$ complete. Preliminary cost estimates for fabricating the drums have been obtained. Meetings have been held with other contractors regarding the shipping and receiving of the drums later this year. The actual disposal of the high-dose waste should occur as scheduled at the end of the fiscal year.

- The completion of modifications to the Radioactive Liquid Waste System (RLWS) has been delayed. The RLWS delay affected planned cask shipments to the 200 Area for final disposition. The estimated usage date of the radioactive liquid waste (RLW) tank is late March 2000. At this time, as much waste as possible is being held for the RLW tank when it comes on line. A change request is being developed to delete waste disposal scope affected by RLWS delays. 
A change request to modify the RLWS baseline to reflect impacts of additional post-start activities was approved by DOE-RL Projects on February 7. The change request included the revised work control processes that were required by Fluor Federal Services' construction management and PNNL's safety and building management staff. A revised Project Authorization Modification for the increased funding requirement issued to DOE-RL on February 7 was approved on February 23. The final RLWS tie-in was completed on February 24. The cover blocks were installed on February 27 and 28. All post-start activities have been completed with the exception of the final inspection of the existing tie-ins by Science Applications International Corporation (SAIC). The SAIC inspection will be completed after the first usage of the RLWS lines. A letter to DOE-RL is being drafted to document completion of the post-start activities and PNNL's intentions to add waste and operate the modified Radioactive Liquid Waste System in the RPL. 


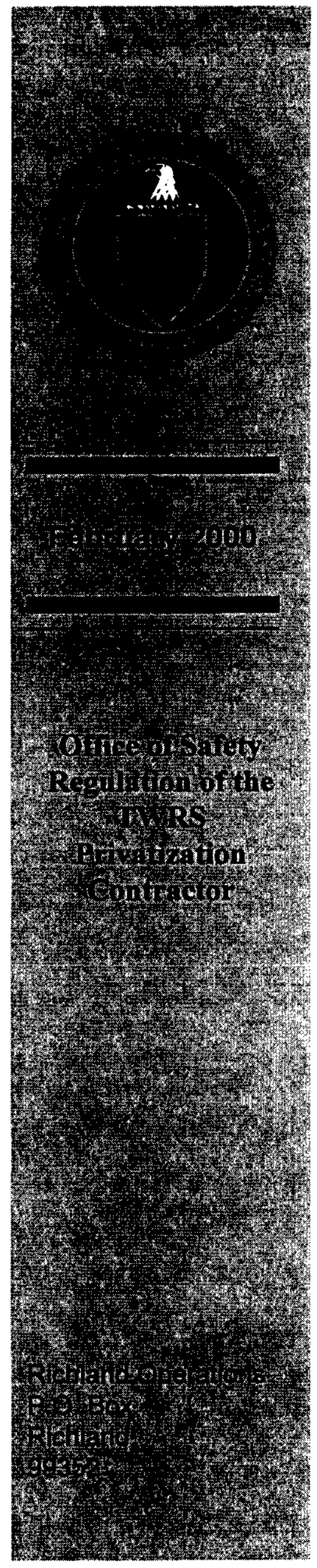

\section{Regulatory Unit}

Monthly Performance Report 


\section{Table of Contents}

EXECUTIVE SUMMARY ................................................................................................................2

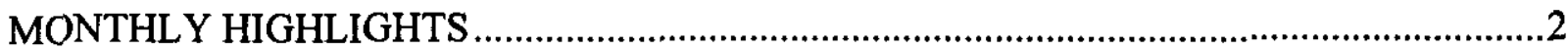

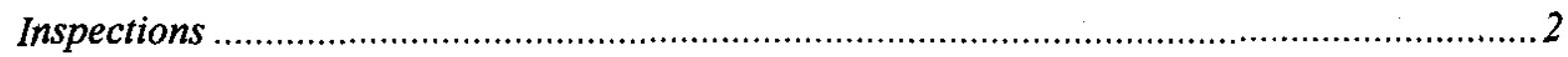

Integrated Safety Management Reviews (ISM Cycle II) .................................................... 3

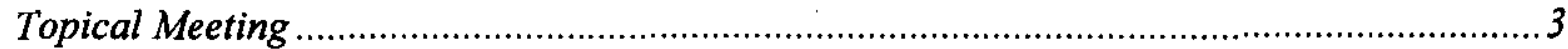

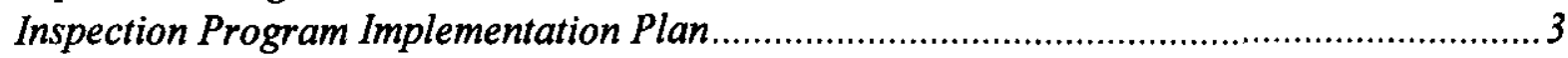

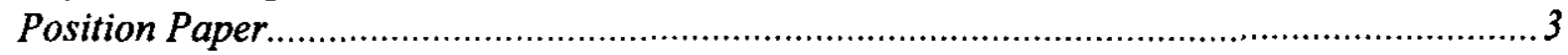

$13^{\text {th }}$ Quarterly

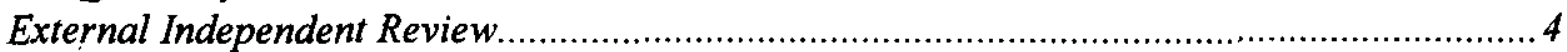

FY 2002 Budget - EH-1 Concurrence and EM-1 Approval .............................................

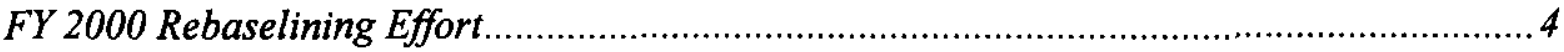

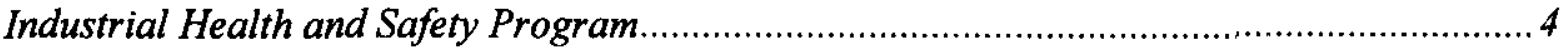

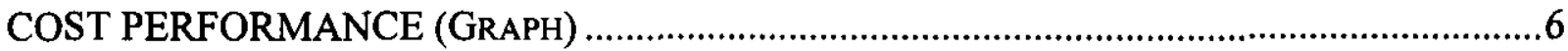

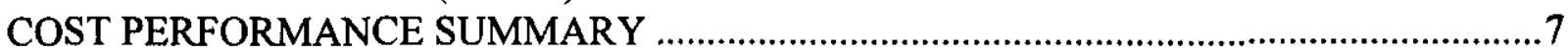

NEAR-TERM LOOK AHEAD

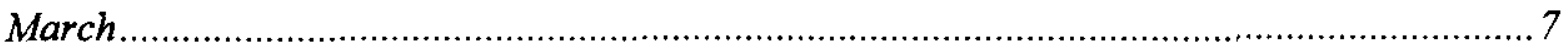

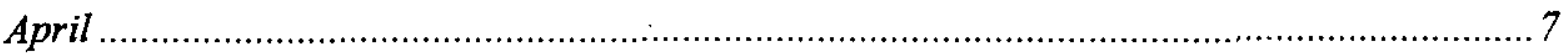

May

PROGRAM PERFORMANCE OVERVIEW .............................................................................8

PERFORMANCE SUMMARY (CHART) - PROGRAM DiReCTION AND PROgRAM SUPPORT...... 9

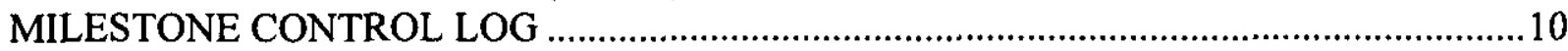

FULL-TIME EQUIVALENCY PROFILE (GRAPH) ……..................................................

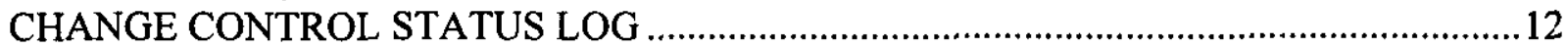




\section{EXECUTIVE OVERVIEW}




\section{EXECUTIVE SUMMARY}

The Regulatory Unit (RU) continues to work with BNFL to resolve three significant issues prior to proceeding with Part B-2: authorization basis ( $\mathrm{AB}$ ) maintenance, dose assessment methodology, and adherence to procedures.

The establishment of an effective process for maintaining the TWRS-P authorization basis continues to be a significant unresolved regulatory issue. BNFL provided a revised response to RU inspection findings related to the authorization basis management process in a letter dated February 24, 2000. The RU met with BNFL management to discuss proposed BNFL corrective actions and is reviewing the revised response. By mid-March a decision will be made by the RU if additional action is warranted.

The RU continues to work with BNFL to correct deficiencies in the dose assessment methodology. The proposed methodology submitted by BNFL in October 1999 was missing necessary detail that would not become known until the Construction Authorization Request (CAR) was submitted. BNFL resubmitted their dose assessment methodology on February 25, 2000 and the RU is evaluating the submittal. It is anticipated that this issue will be resolved in late March.

Nearly all of the design phase RU inspections of BNFL have identified procedure compliance problems. To address this concern, BNFL established a team to determine the root causes of this problem. The results were presented to the RU management team during a workshop session, and a second response was issued to the RU on February 25, 2000 to address the problem. The second response included a Response to Finding that addresses remedial (near-term) actions for the specific deficiencies noted in the finding, taking into account the concerns noted by the RU in their February 8 , 2000 letter. In addition, BNFL has addressed the corrective actions for root causes believed to be at the heart of this finding.

\section{MONTHLY HIGHLIGHTS}

\section{Inspections}

The RU performed a second inspection of the BNFL's Employee Concern Program (ECP), and did not identify any Findings. The inspection indicated that the contractor had implemented an effective Employee Concern Program as required by the Contract. The ECP's ability to resolve concerns is still untested since no concerns have been identified to date. The previous inspection concluded that an Employee Concerns Program had not been implemented. The Employee Concern Program Inspection Report was issued in March.

Development of construction inspection procedures is underway with ten of the forty procedures required for the Limited Construction Authorization/Construction Authorization completed. 


\section{Integrated Safety Management Reviews (ISM Cycle II)}

RU observation of BNFL Integrated Safety Management (ISM) Cycle 2 activities is ongoing. Safety review meetings associated with hazard identification or control strategy selection for pretreatment of high and low activity waste vitrification systems continue to be held on a regular basis. The RU staff met to discuss observations from ISM meetings attended to date and to identify any negative trends or concerns. Some weaknesses in the BNFL ISM process were identified. The RU is preparing correspondence to BNFL transmitting these concerns.

\section{Topical Meeting}

The $16^{\text {th }}$ Topical Meeting between the RU and BNFL was held to discuss the proposed electrical system design for the vitrification facility. The integrated safety management (ISM) process identified the electrical system as a key factor in facility safety.

\section{Inspection Program Implementation Plan}

The RU issued an update to the Inspection Program Implementation Plan (IPIP) for the Regulatory Oversight of the TWRS Privatization Contractor. The IPIP provides inspection-related administrative requirements; describes Inspection Program activities that are common to all phases of the TWRS-P Program; and identifies specific administrative and technical procedures used to implement the Inspection Program. This revision upgrades the IPIP to reflect the anticipated inspection program for the limited and full construction phases of the project.

\section{Position Paper}

The RU issued a Position on Acceptability of the TWRS-Privatization Dose Standards for Unlikely and Extremely Unlikely Events. The paper presented the results of a review of the acceptability of the radiation dose standards for postulated accidents at the proposed TWRS-P facility. These standards are part of a process used to ensure that the facility is provided with adequate structures, systems, and components that are important to safety. It is the RU position that the accident dose standards established in BNFL's Safety Requirements Document are appropriate as part of the contractual regulatory process that provides adequate safety for workers, co-located workers, and the public.

\section{$13^{\text {th }}$ Quarterly}

Dr. Clark Gibbs and Dr. Narinder Kaushal of the RU met with representatives of DOE Headquarters, the U.S. Nuclear Regulatory Commission (NRC), and the Defense Nuclear Facilities Safety Board in Washington D.C. to present the $13^{\text {th }}$ quarterly briefing of regulatory activities in support of the BNFL TWRS-P Waste Treatment Plant (WTP). Topics presented included the following:

- Oversight of BNFL design review and integrated safety management activities

- Inspections performed and associated findings

- Results of Topical Meetings held with BNFL 
- Implementation of industrial health and safety responsibilities

- TWRS-P WTP regulatory documents issued

- Developments in the revision of the memorandum of understanding between the DOE and NRC

- Regulatory Program funding requirements

No actions resulted from the briefing

\section{External Independent Review}

The External Independent Review (EIR) Team, which is assessing DOE's Readiness to Proceed with Phase I, Part B-2 of TWRS Privatization, gave their assessment following a week of data gathering. The EIR noted that the Office of River Protection (ORP), RL, and the RU had prepared well for their data-gathering visit, had strong management focus and had a high rate of progress in the past 60 days. The RU staff provided selected members of the EIR Team with a 30-minute opening presentation, participated in a 2-hour breakout session and provided an introduction to the RU Website. The EIR team had positive comments on the quality and content of the review guidance for the Construction Authorization Request and the content of the RU Website. The EIR will begin a detailed review of Phase I, Part B-2 Readiness on April 3, 2000.

\section{FY 2002 Budget - EH-1 Concurrence and EM-1 Approval}

By way of a memorandum from the RL Manager, the RU requested EH-1 concurrence with and EM-1 approval of its FY 2002 budget. In keeping with the provisions of the MOA and remaining consistent with past practices, EH-1 concurrence and EM-1 approval are needed for both the Program Direction (PD) and Program Support (PS) budgets for the RU. The reduction in FY 2002 to $\$ 6.7 \mathrm{M}$ from the approved FY 2001 profile of $\$ 9.1 \mathrm{M}$ stems primarily from the projected completion in FY 2001 of the Construction Authorization Request review, a thirty week effort requiring significant FTE resources; and the near-completion of the design review activities.

\section{FY 2000 Rebaselining Effort}

The RU conducted a detailed review of the resource requirements for the upcoming safety review activities. Utilizing the Regulatory Program's FYTD cost savings and realigning the currently known resources, the RU was able to adequately cover all projected resource needs throughout the review cycles. On February 25, 2000 the Regulatory Official approved the baseline change request.

\section{Industrial Health and Safety Program}

The RU is continuing to define a comprehensive program for regulating non-radiological worker safety and health. The status of the essential elements of this IH\&S regulatory program are as follows:

- The Policy and Memorandum of Agreement (MOA) documents were modified to add the top-level framework for non-radiological safety regulation. The documents were reviewed internally and by $\mathrm{HQ}$, and were modified per comments from Environmental Management (EM) and General Counsel.

- The RU's direction on design review (RL/REG-099-07) was revised to reflect IH\&S 
considerations and will be reissued in March.

- The RU prepared a draft Regulatory Plan describing the processes it will follow internally in regulating IH\&S. The Regulatory Plan was sent to BNFL for review and comment in early March.

- The RU issued a position paper (revision 2) on regulating IH\&S to BNFL for review and comment.

- BNFL continues to develop a description of their IH\&S program for construction per the review guidance issued by the RU in January. BNFL is scheduled to submit the document on April 24, 2000.

The RU is developing an IH\&S inspection program. The basic scope of the program was provided to BNFL as part of the draft Regulatory Plan. 


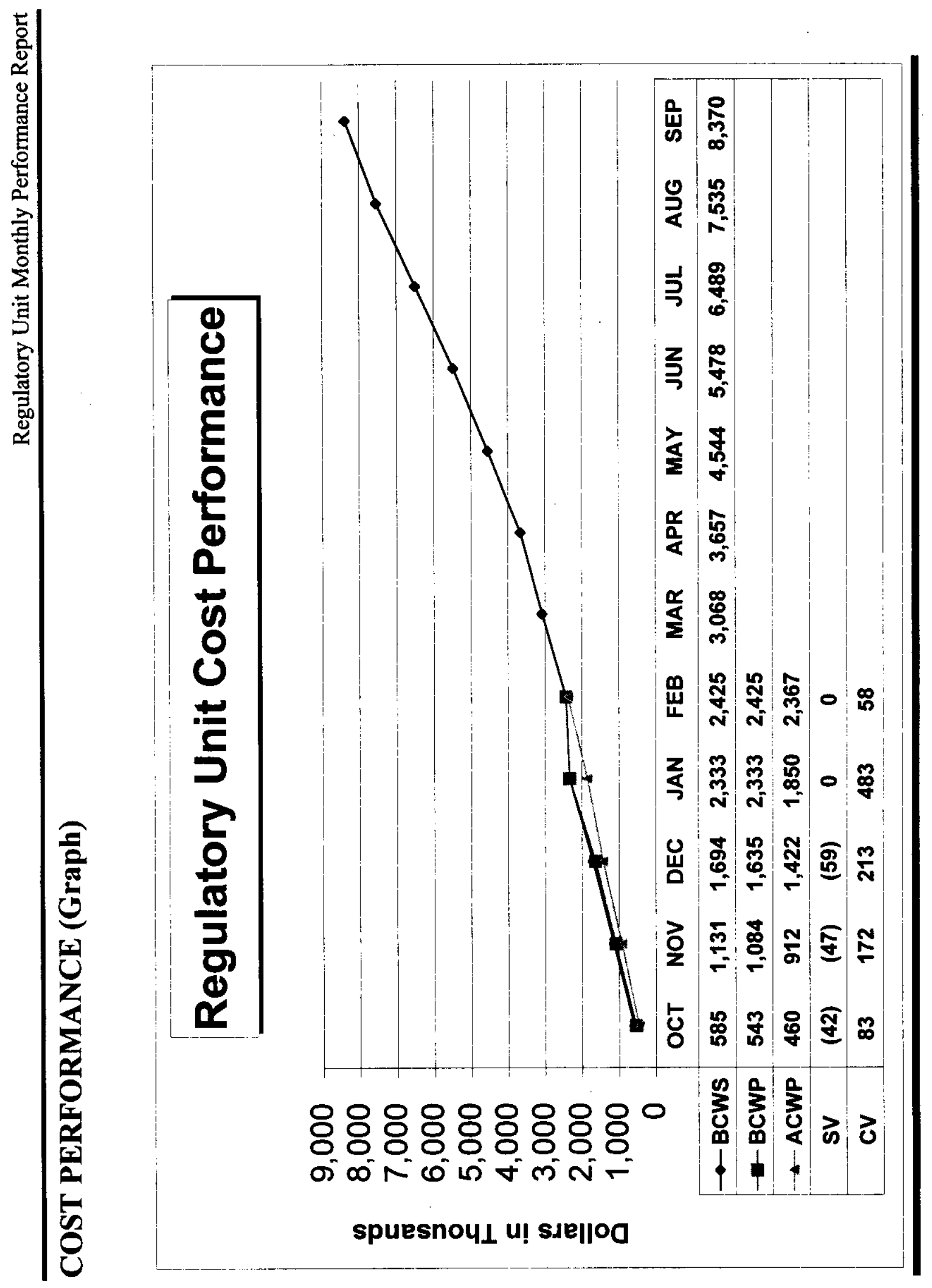




\section{COST PERFORMANCE SUMMARY}

The fiscal year-to-date cost through February reflects a favorable cost variance of $\$ 58 \mathrm{~K}$ and is considered insignificant. All activities are currently performing on track or very close to the baseline schedule.

\section{NEAR-TERM LOOK AHEAD}

\section{March}

- Conduct Authorization Basis Corrective Action Meeting

- Conduct Training \& Qualification Inspection

- Issue Employee Concerns Program Inspection Report

- Issue Non-Radiological Safety \& Health Review Handbook

- Conduct Topical Meeting on LAW/HLW Melter Design \& Safety Issues

\section{April}

- Issue Training \& Qualification Inspection Report

$4-07-00$

- Issue QAPIP Review Handbook

$4-07-00$

- Conduct Corrective Actions Inspection

$4-24-00$

- Conduct Topical Meeting on Chemical Hazards

$4-25-00$

- Commence Review of BNFL IH\&S Program Description

$4-25-00$

May

- Issue IH\&S Regulatory Plan

- Issue SAP Review Handbook

- Commence Review of BNFL SAP

$5-15-00$

- Conduct Standards Implementation Inspection

$5-15-00$

- Issue LCA Review Handbook

$5-17-00$

- Present $14^{\text {th }}$ Quarterly Briefing to Headquarters

$5-18-00$

- Conduct Topical Meeting on $2^{\text {nd }}$ Iteration: Hazards Control Strategies

$5-23-00$

- Issue Corrective Action Inspection Report

$5-30-00$ 


\section{PROGRAM PERFORMANCE OVERVIEW}



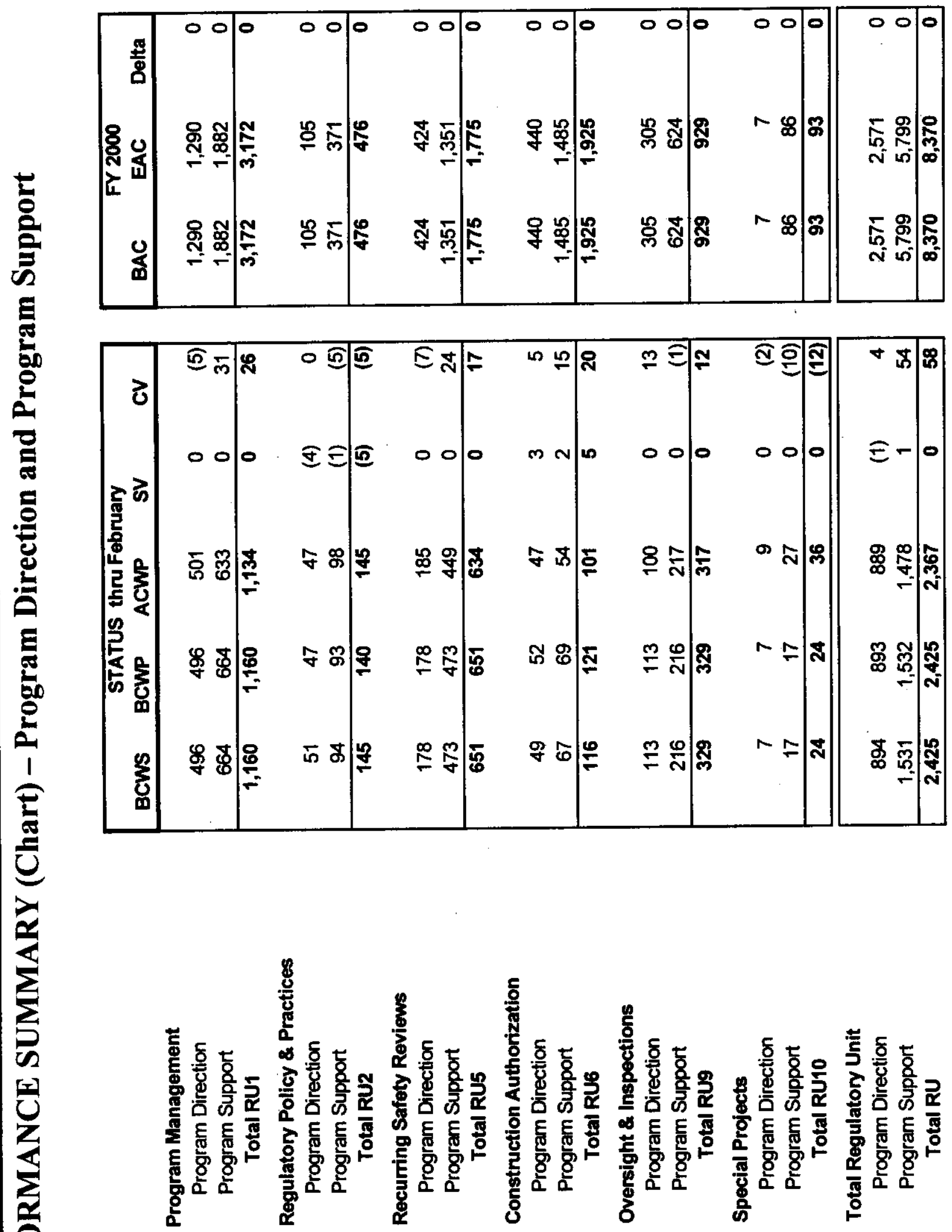

产

곰

$\stackrel{\mathscr{2}}{\not{\alpha}}$

$\stackrel{g}{\vec{x}}$

$\frac{\text { 움 }}{2}$ 


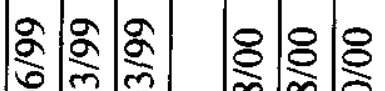 号}
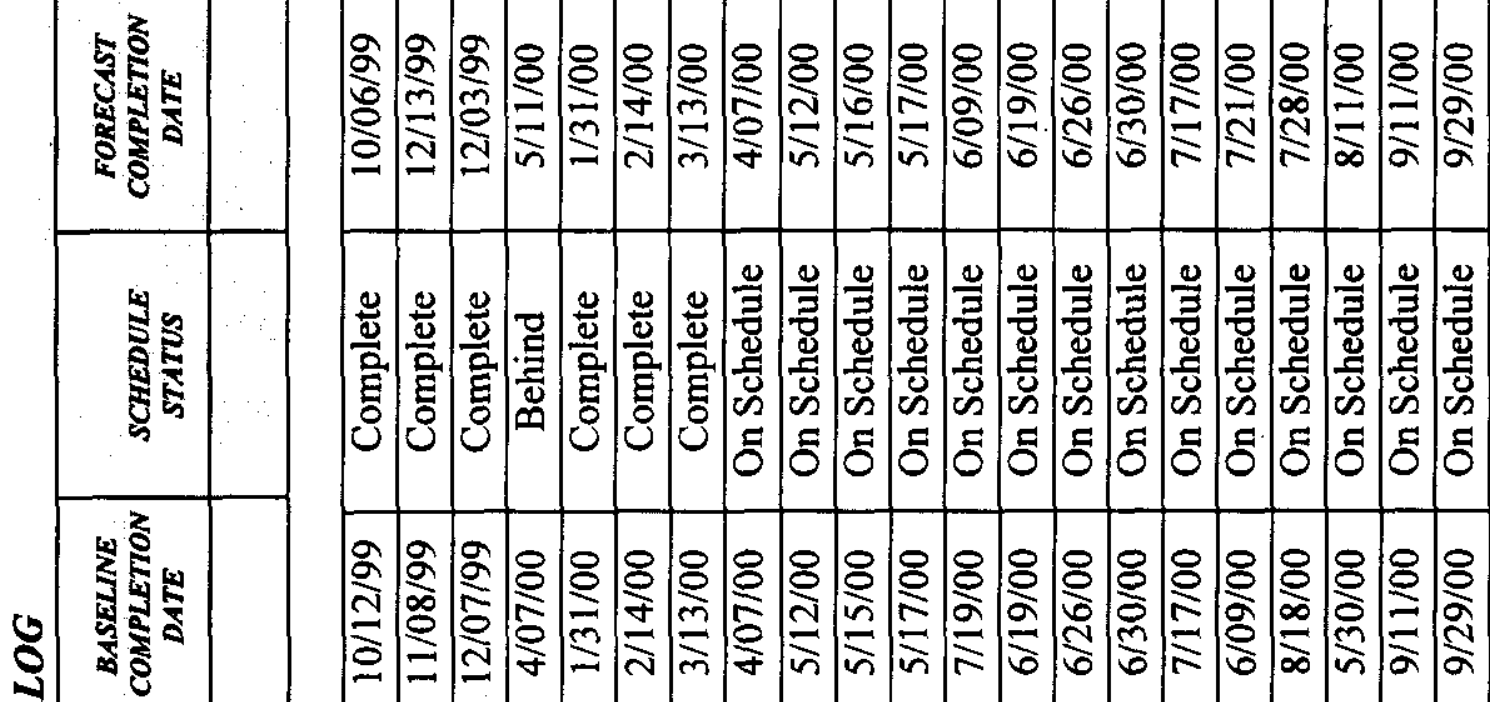

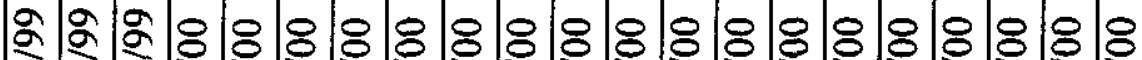

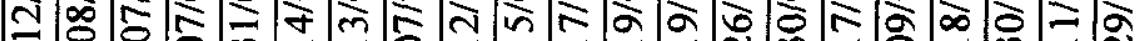

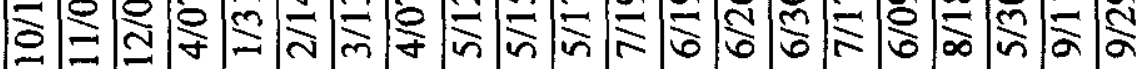

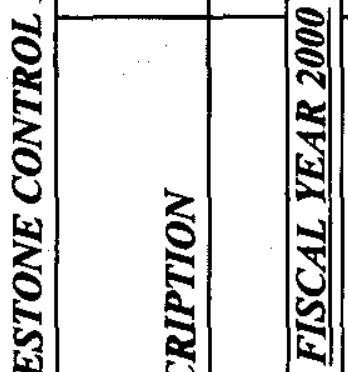

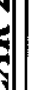

金总

灵荡要

兽

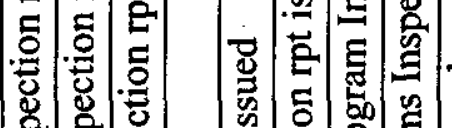

蛋

参总总

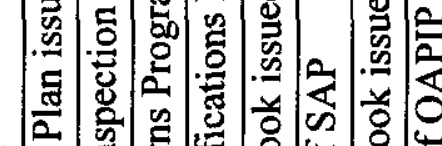

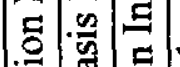

莺

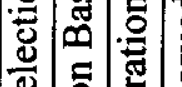

:

要

总

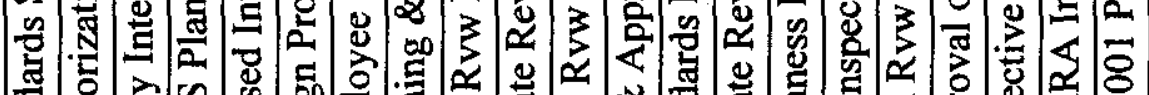

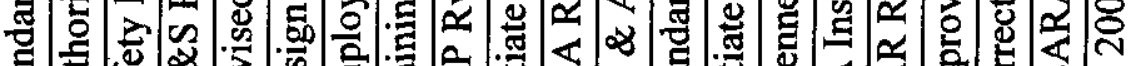

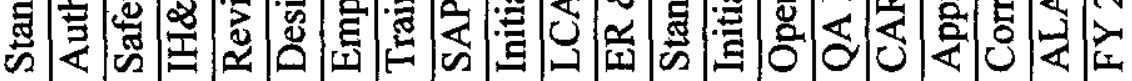

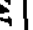

a

융

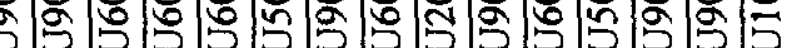

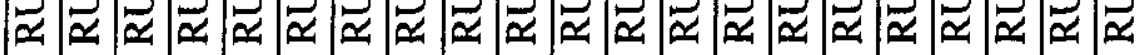

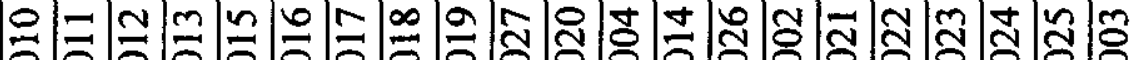

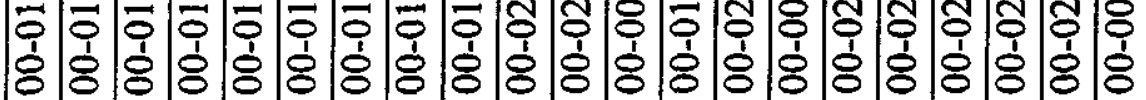

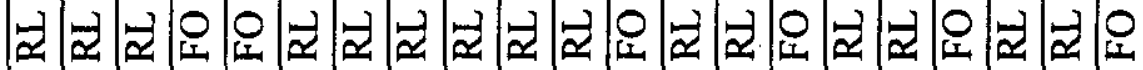



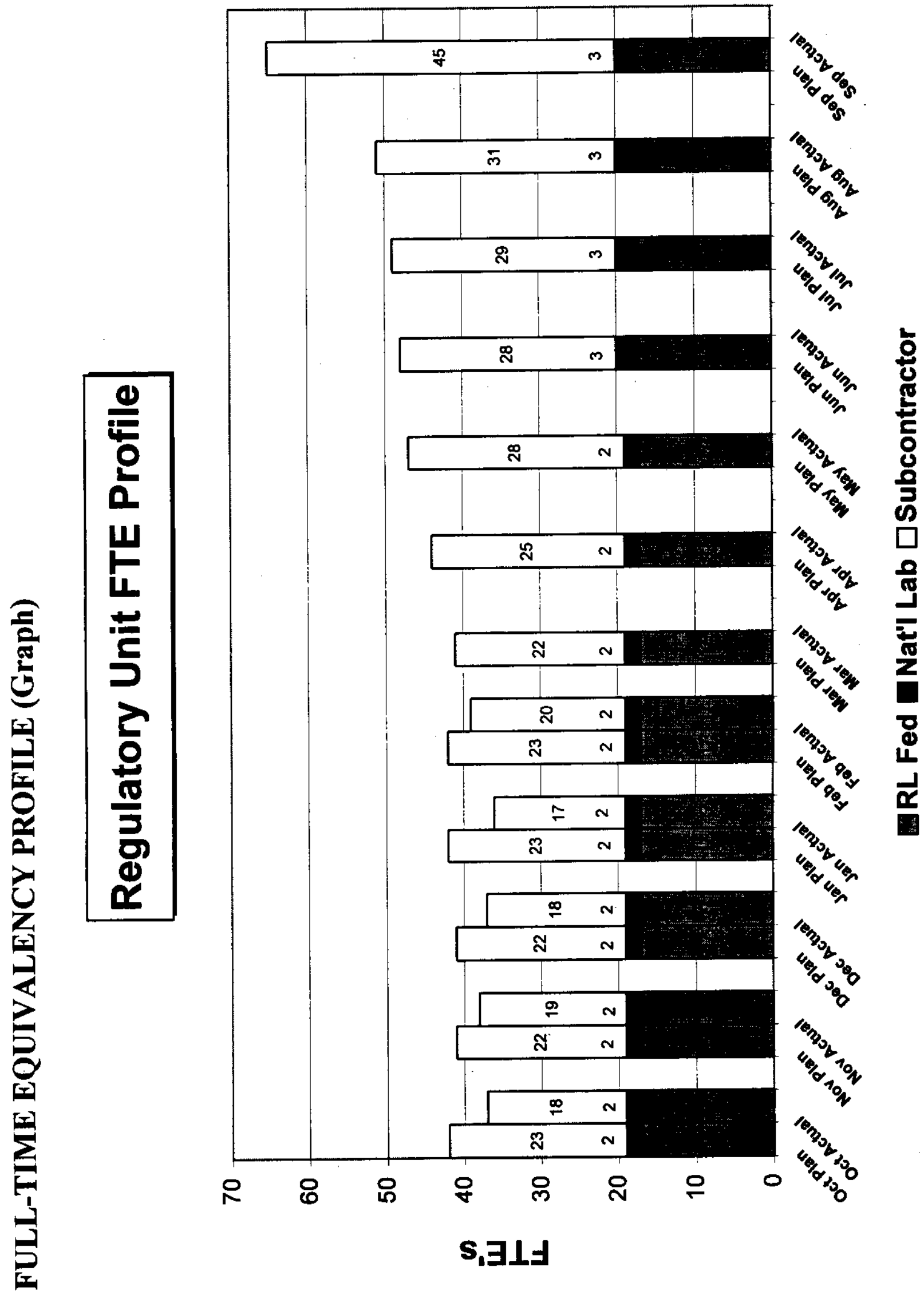

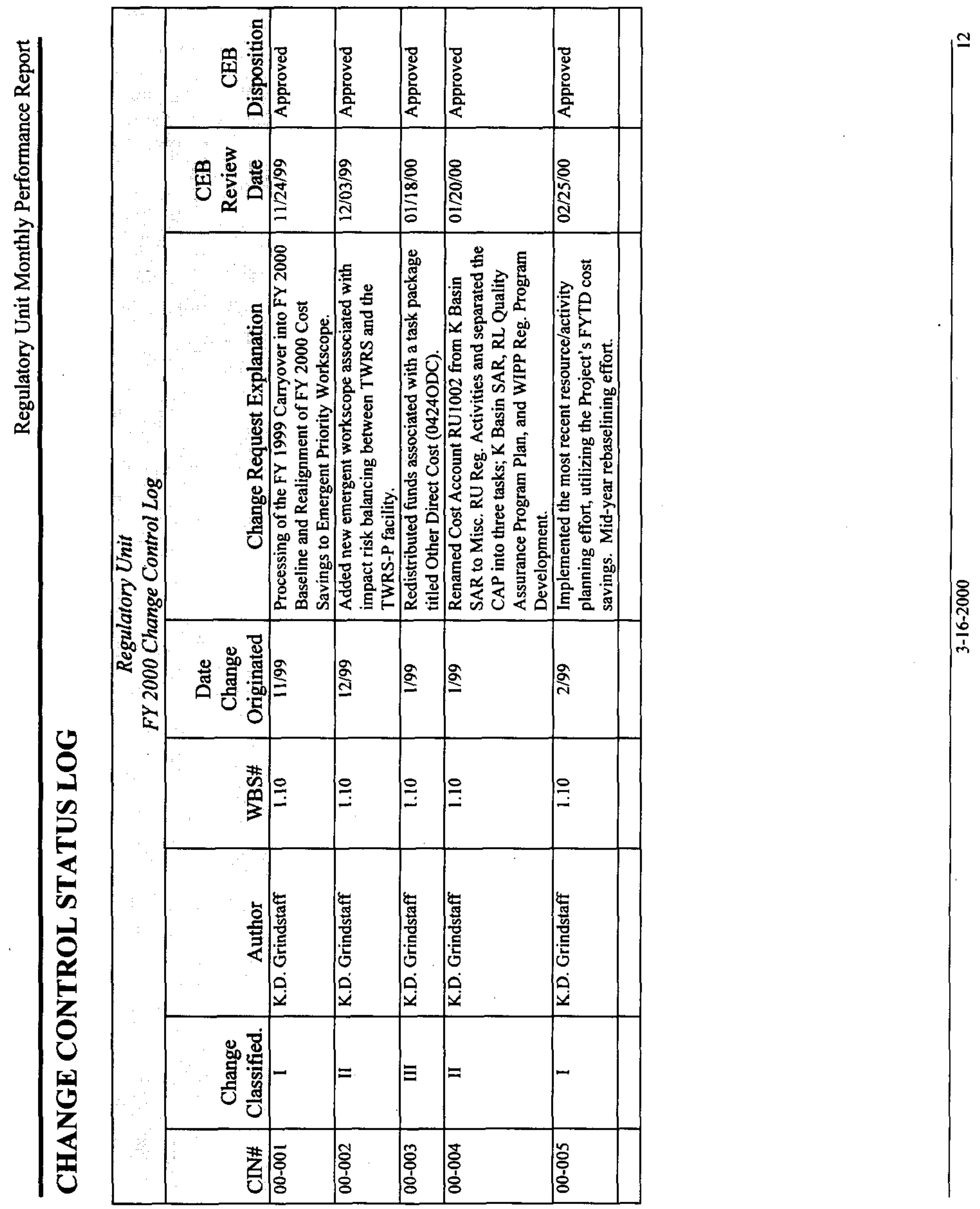


\section{GLOSSARY}

Actual cost of work performed (ACWP): The actual cost incurred and applied or distributed for the work performed within a given time period. It includes all labor categories, material, any other direct costs, subcontract work, and function overhead.

Approved baseline: The budget authorized to perform the workscope that has been agreed upon by the customer and the contractor(s). It is portrayed in the Multi-Year Work Plan with all approved changes. This baseline may or may not be fully funded, and could be more or less than the compliance baseline.

Budget at completion (BAC): The sum of budgets established to complete a program and/or project or any component of a program and/or project.

Budgeted cost of work performed (BCWP): The value for completed work measured in terms of the planned budget for that work. It is synonymous with earned value.

Budgeted cost of work scheduled (BCWS): The time-phased budgeted value of work scheduled to be accomplished over a given time period. The BCWS for a total cost account through its entire period of performance is equal to the BAC for the cost account.

Carryover Workscope: The estimated dollar amount of the workscope that was not completed during the fiscal year and which will be carried over and completed in the next fiscal year.

Compliance baseline: The budget that is required to perform the workscope necessary to be in compliance with State and Federal regulations, enforceable agreement milestones, and DNFSB milestones. The level of activity required to be in compliance assumes sufficient funding. Note: Because approved baselines are considered to be compliant, this column will likely be eliminated.

Contract Inherited: The assumed budget for the planned scope of work at the time a new contract is signed by the company responsible for performing the work.

Cost variance (CV): The difference between BCWP and ACWP (CV = BCWP - ACWP). At any time, it shows whether the work actually performed has cost more or less than the amount budgeted for the same work.

Cost Performance Indicator (CPI): The CPI is the ratio of BCWP to ACWP, or (BCWP/ACWP).

Earned value (EV): The periodic, consistent, and objective measurement of work performed in terms of the budget planned for that work. The EV is synonymous with the BCWP and it is compared to the BCWS to obtain schedule performance and to the ACWP to obtain cost performance. 


\section{GLOSSARY (CONTINUED)}

Estimate at completion (EAC): Cost allocated to the work breakdown structure element to date, plus the estimate of costs for authorized work remaining. Authorized work remaining includes any undistributed budget.

Fiscal Year Spending Forecast (FYSF): The estimated total that will be spent from October through September (current Fiscal Year).

Funding carryover and new Budget Authorization (BA): This funding represents both the funding allocated to perform workscope planned in the prior fiscal year, not completed, and approved to be performed in the current fiscal year, as well as new BA to perform the approved baseline workscope.

Funding target: The level of funding that is anticipated (as a result of the Integrated Priority List process) in a given Fiscal Year based on an assumed funding level for the Site.

Multi-Year Work Plan - 10/1/XX: The Project's approved cost/schedule/technical baseline at the beginning of the fiscal year.

Project Execution Module (PEM): The Project Execution Module (PEM) of the Integrated Planning, Accountability, and Budgeting System-Information System (IPABS-IS) replaces the Progress Tracking System (PTS) as EM Headquarters' centralized system for reporting financial, milestone, performance, and other execution-year information for PBSs, sub-PBSs, TTPs, and line item construction projects. In addition, this module collects mid-year and year-end actual performance information against the agreed upon management commitments for the current execution year.

Schedule Performance Indicator (SPI): The SPI is the ratio of BCWP to BCWS, or (BCWP/BCWS).

Schedule variance (SV): The difference between BCWP and BCWS (SV = BCWP - BCWS). At any time, or for a given period of time, it represents the difference between the planned dollar value of work actually accomplished and the value of the work scheduled to be accomplished.

Work breakdown structure (WBS): A product-oriented family tree division of real estate, hardware, software, services, and data products that organize, define, and display all of the work to be performed in accomplishing the program and/or project objectives. 


\section{CORRESPONDENCE DISTRIBUTION COVERSHEET}

Author

G. J. McCleary, FDH

(D. M. Eder, 376-0755)

Addressee

G. M. Bell, RL

Correspondence No.

FDH-9553093 R57

Subject: CONTRACT NO. DE-AC06-96RL13200 -
PERFORMANCE REPORT - APRIL 2000

\section{DISTRIBUTION}

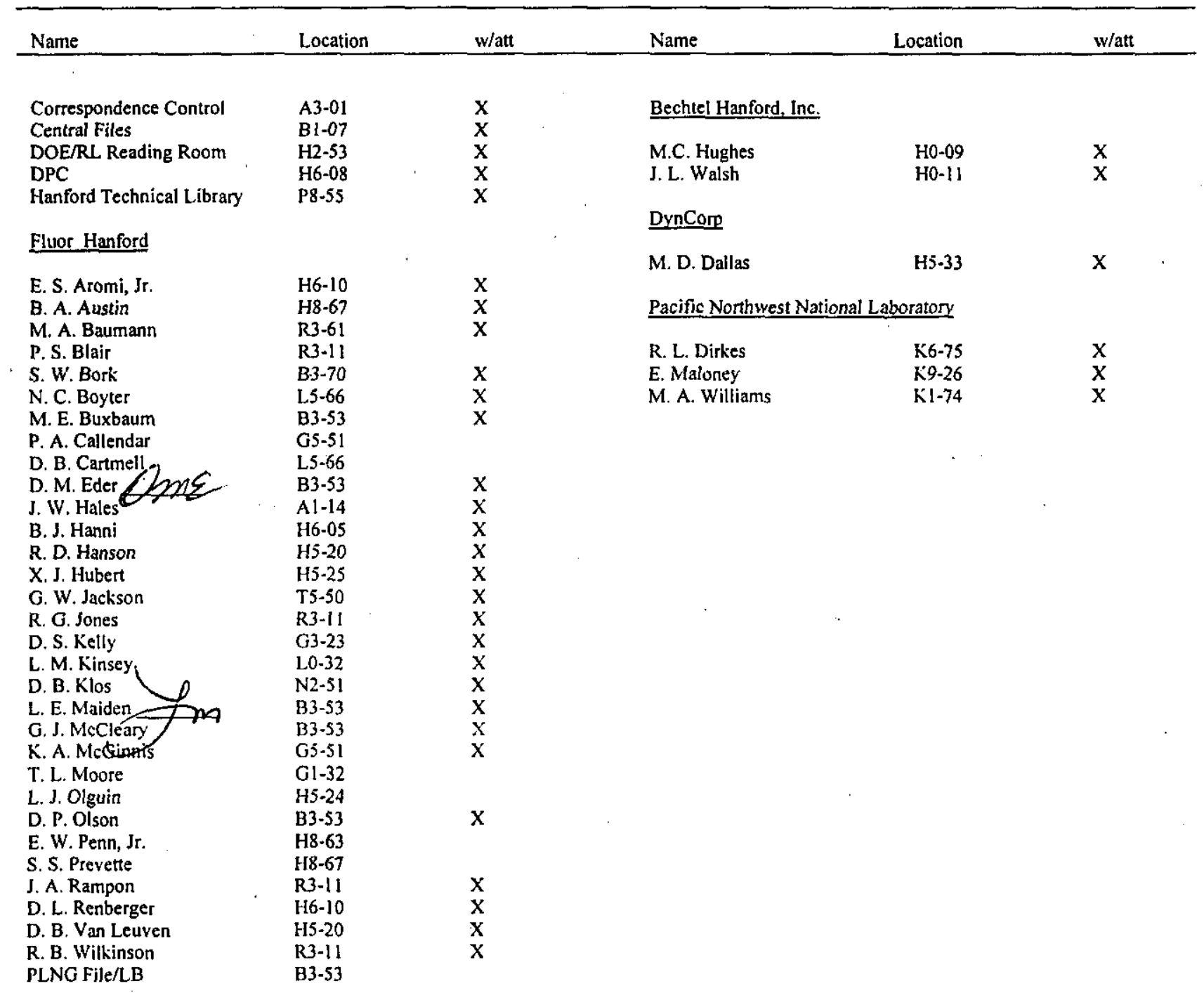


Mr. G. M. Bell, Director

Analysis and Evaluation Division

U.S. Department of Energy

Richland Operations Office

Post Office Box 550

Richland, Washington 99352

Dear Mr. Bell:

CONTRACT NO. DE-AC06-96RL13200 - ENVIRONMENTAL MANAGEMENT PERFORMANCE REPORT - APRIL 2000

Attached is DOE/RL-99-83, Revision 3, "Environmental Management Performance Report April 2000," which was delivered to U.S. Department of Energy, Richland Operations Office in bound copy on April 7, 2000. This report has been separated into four sections: Project Hanford Management Contract, Environmental Restoration Contract (ERC), Science and Technology and Regulatory Unit. Please note that in the ERC section some of the rating boxes are blank. The ratings can be obtained electronically on the shared area 'Pbs on AP014', as well as the web site noted below. Site Planning and Integration will continue to work with your staff regarding any additional enhancements to the report.

The monthly Environmental Management Performance Report is available on the Internet. The

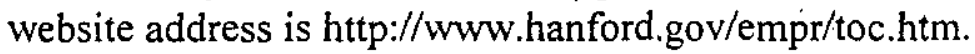

If you have any questions, no longer require the report in hard copy, or have problems accessing it electronically, please contact Mr. D. M. Eder of my staff at 376-0755.

Very truly yours,

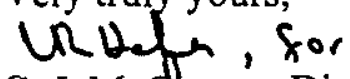

G. J. Mccleary, Director

Project Controls

cas

Attachment

DOE-HQ - R. Lightner

RL - S. A. Sieracki w/o att.

V. Skinner w/o att. 